Supporting Information:

\title{
Carbodiimide Synthesis via Ti-Catalyzed Nitrene Transfer from Diazenes to Isocyanides
}

Evan P. Beaumier, Meghan E. McGreal, Adam R. Pancoast, R. Hunter Wilson, James T. Moore, Brendan J. Graziano, Jason D. Goodpaster, Ian A. Tonks*

Department of Chemistry, University of Minnesota-Twin Cities, 207 Pleasant Street SE, Minneapolis, Minnesota 55455, United States. E-mail: itonks@umn.edu, jgoodpas@umn.edu

\section{Table of Contents:}

Data for Table 1. Figures S1-S10 and Tables S1-S4.

S2

Data for Table 2. Figures S11-S38.

Procedures and NMR spectra for isolation of 1-tert-butyl-3-aryl carbodiimides.

Figures S39-S55.

Scale up procedure for the isolation of 1-tert-butyl-3-phenylcarbodiimide.

Figure S56.

S61

Data for Table 3. Procedures and NMR spectra for isolation of adamantyl-

substituted carbodiimides. Figures S57-S61.

S62

Procedure for the carbodiimide metathesis reaction of 1-tert-butyl-3-

S68

phenylcarbodiimide with 1d and discussion. Figure S62.

Procedure for the same $[\mathrm{xs}]$ experiment and discussion. Figure S63-S64. $\quad$ S70

Procedure for the additive test with 1-(2,6)-xylyl)-3-phenylcarbodiimide and 1- $\quad \mathbf{S 7 3}$

cyclohexyl-3-phenylcarbodiimide. Figure S65.

NMR spectra for complexes 1b and 1d. Figures S66-S69.

$50 \%$ Ellipsoid drawing of $1 \mathrm{~d}$. Figure S70.

Crystal and refinement data for complex 1d. Table S5.

Computational protocol and data. Figures S71-S72 and Tables S6-S8.

S79

References

S122 


\section{Optimization Reactions from Table 1:}

NMR tube reaction of azobenzene and tert-butylisocyanide catalyzed by 1 a to form 1-tertbutyl-3-phenylcarbodiimide (2a) and 1,3-di-tert-butylcarbodiimide (3) (Table 1 Entry 1):

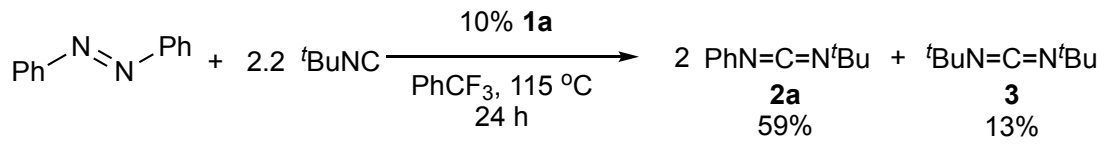

1-tert-butyl-3-phenylcarbodiimide (partial line list):

${ }^{1} \mathrm{H}$ NMR (400 MHz, $\mathrm{PhCF}_{3}, 25^{\circ} \mathrm{C}, \delta$, ppm): 1.25 (s, 9H, $\left.-\mathrm{C}\left(\mathrm{CH}_{3}\right)_{3}\right)$.

1,3-di-tert-butylcarbodiimide:

${ }^{1} \mathrm{H}$ NMR (400 MHz, $\mathrm{PhCF}_{3}, 25^{\circ} \mathrm{C}, \delta$, ppm): 1.22 (s, $\left.18 \mathrm{H},-\mathrm{C}\left(\mathrm{CH}_{3}\right)_{3}\right)$.

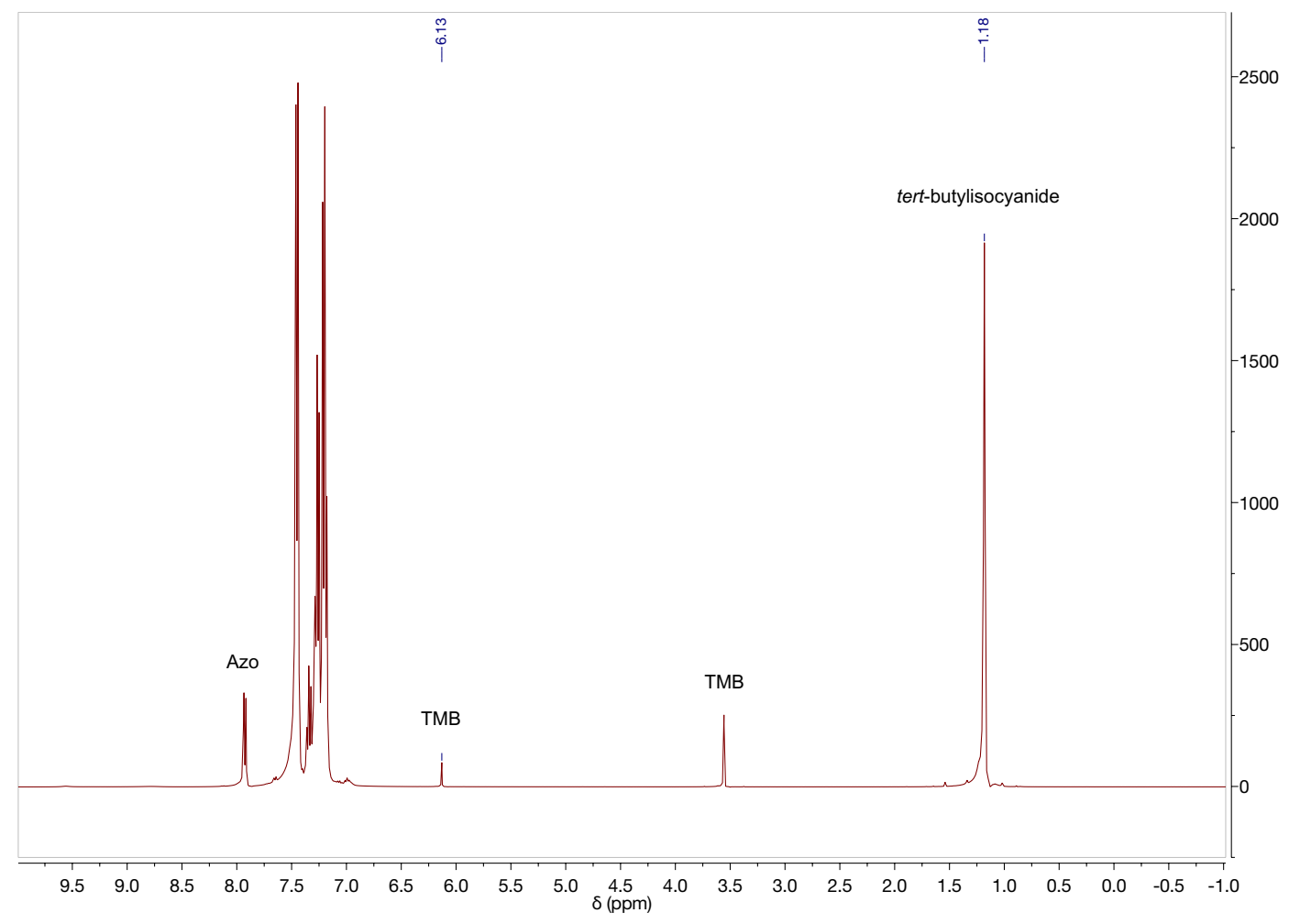

Figure S1. Representative No-D NMR spectrum of the reaction of azobenzene and tertbutylisocyanide at $\mathrm{t}=0$ in $\mathrm{PhCF}_{3}$. 


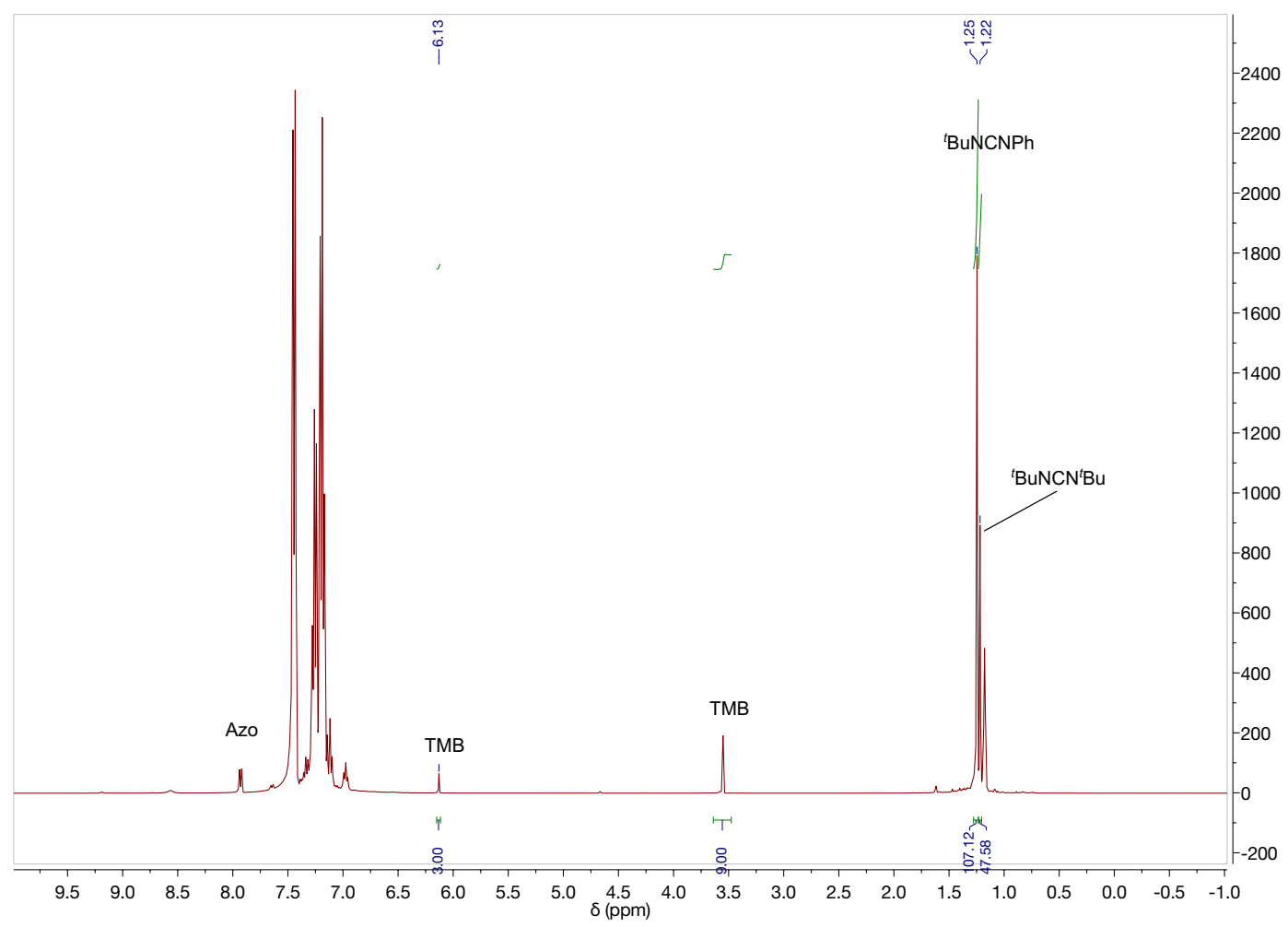

Figure S2. No-D NMR spectrum of the reaction of azobenzene and tert-butylisocyanide catalyzed by $\mathbf{1 a}$ at $\mathrm{t}=24 \mathrm{~h}$ in $\mathrm{PhCF}_{3}$ showing the formation of 1-tert-butyl-3phenylcarbodiimide (2a) and 1,3-di-tert-butylcarbodiimide (3). 
NMR tube reaction of azobenzene and tert-butylisocyanide catalyzed by $\mathbf{1 b}$ to form 1-tertbutyl-3-phenylcarbodiimide (2a) and 1,3-di-tert-butylcarbodiimide (3) (Table 1 Entry 2):
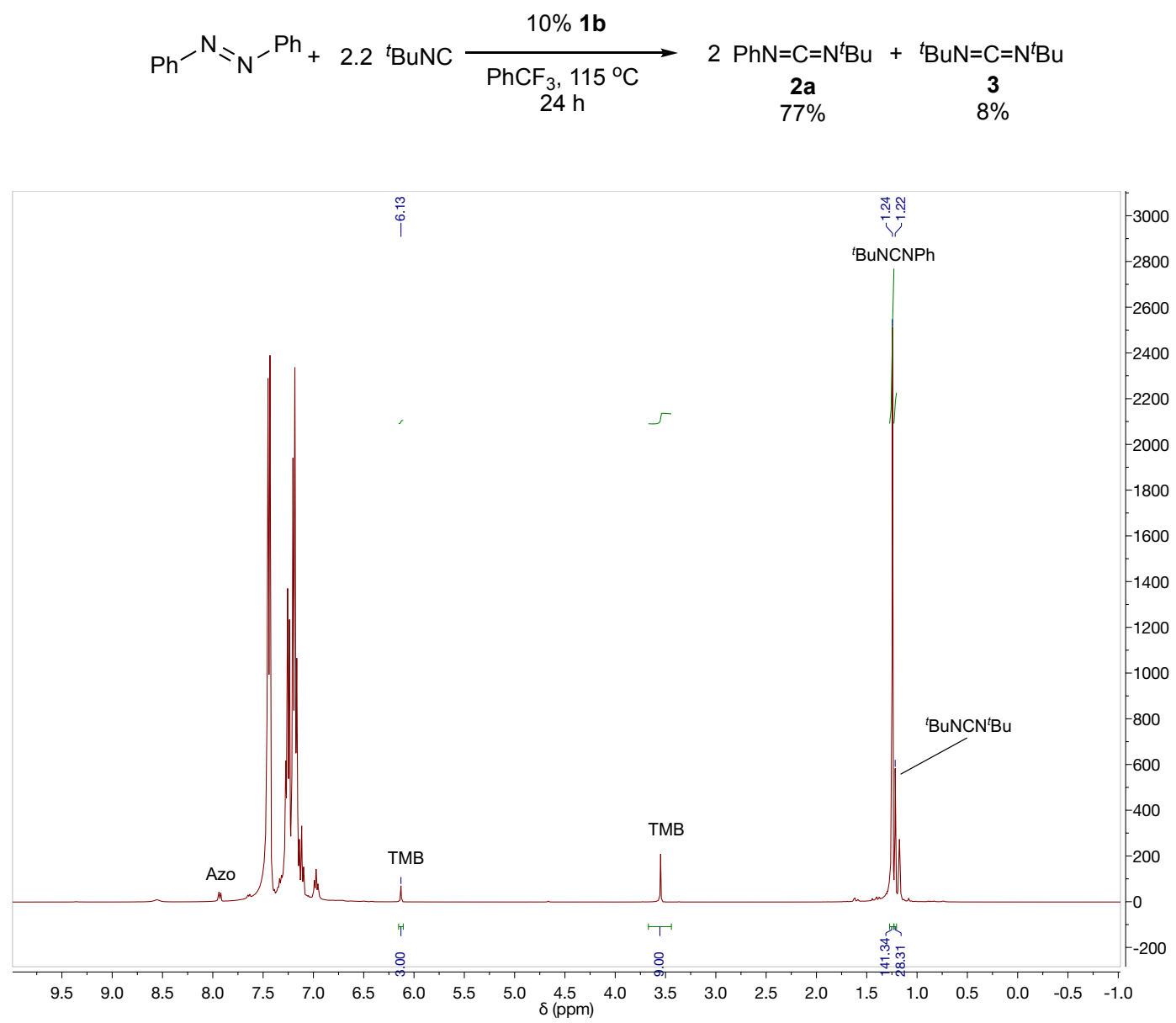

Figure S3. No-D NMR spectrum of the reaction of azobenzene and tert-butylisocyanide catalyzed by $\mathbf{1 b}$ at $\mathrm{t}=24 \mathrm{~h}$ in $\mathrm{PhCF}_{3}$ showing the formation of 1-tert-butyl-3phenylcarbodiimide (2a) and 1,3-di-tert-butylcarbodiimide (3). 
NMR tube reaction of azobenzene and tert-butylisocyanide catalyzed by $1 \mathbf{c}$ to form 1-tertbutyl-3-phenylcarbodiimide (2a) and 1,3-di-tert-butylcarbodiimide (3) (Table 1 Entry 3):
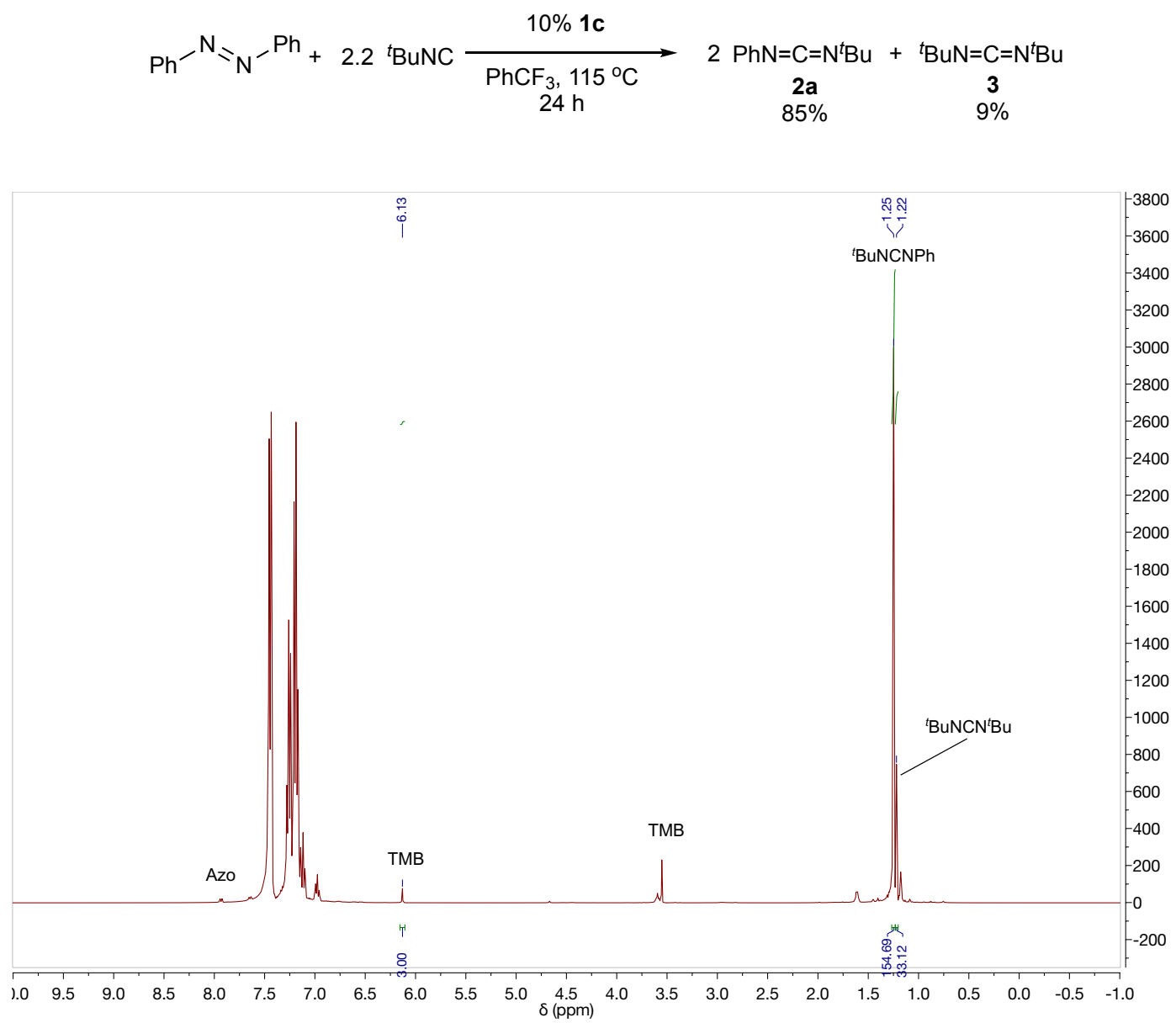

Figure S4. No-D NMR spectrum of the reaction of azobenzene and tert-butylisocyanide catalyzed by $1 \mathrm{c}$ at $\mathrm{t}=24 \mathrm{~h}$ in $\mathrm{PhCF}_{3}$ showing the formation of 1-tert-butyl-3phenylcarbodiimide (2a) and 1,3-di-tert-butylcarbodiimide (3). 
NMR tube reaction of azobenzene and tert-butylisocyanide catalyzed by $\mathbf{1 d}$ to form 1-tertbutyl-3-phenylcarbodiimide (2a) and 1,3-di-tert-butylcarbodiimide (3) (Table 1 Entry 4):
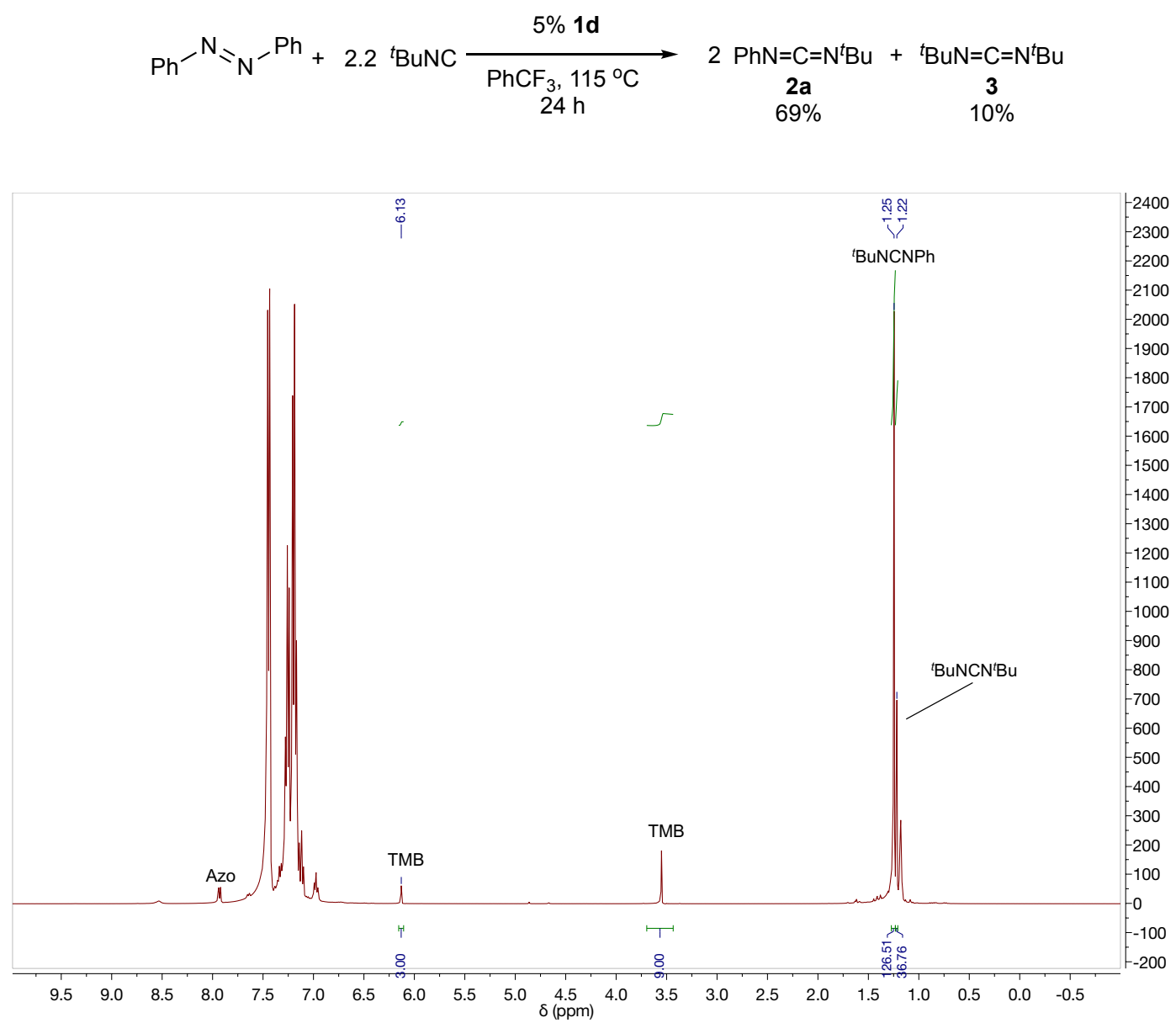

Figure S5. No-D NMR spectrum of the reaction of azobenzene and tert-butylisocyanide catalyzed by $1 \mathrm{~d}$ at $\mathrm{t}=24 \mathrm{~h}$ in $\mathrm{PhCF}_{3}$ showing the formation of 1-tert-butyl-3phenylcarbodiimide (2a) and 1,3-di-tert-butylcarbodiimide (3). 
NMR tube reaction of azobenzene and excess tert-butylisocyanide catalyzed by $\mathbf{1 d}$ to form 1-tert-butyl-3-phenylcarbodiimide (2a) and 1,3-di-tert-butylcarbodiimide (3) (Table 1 Entry 5):

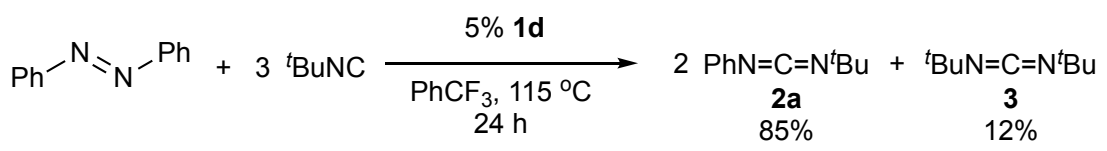

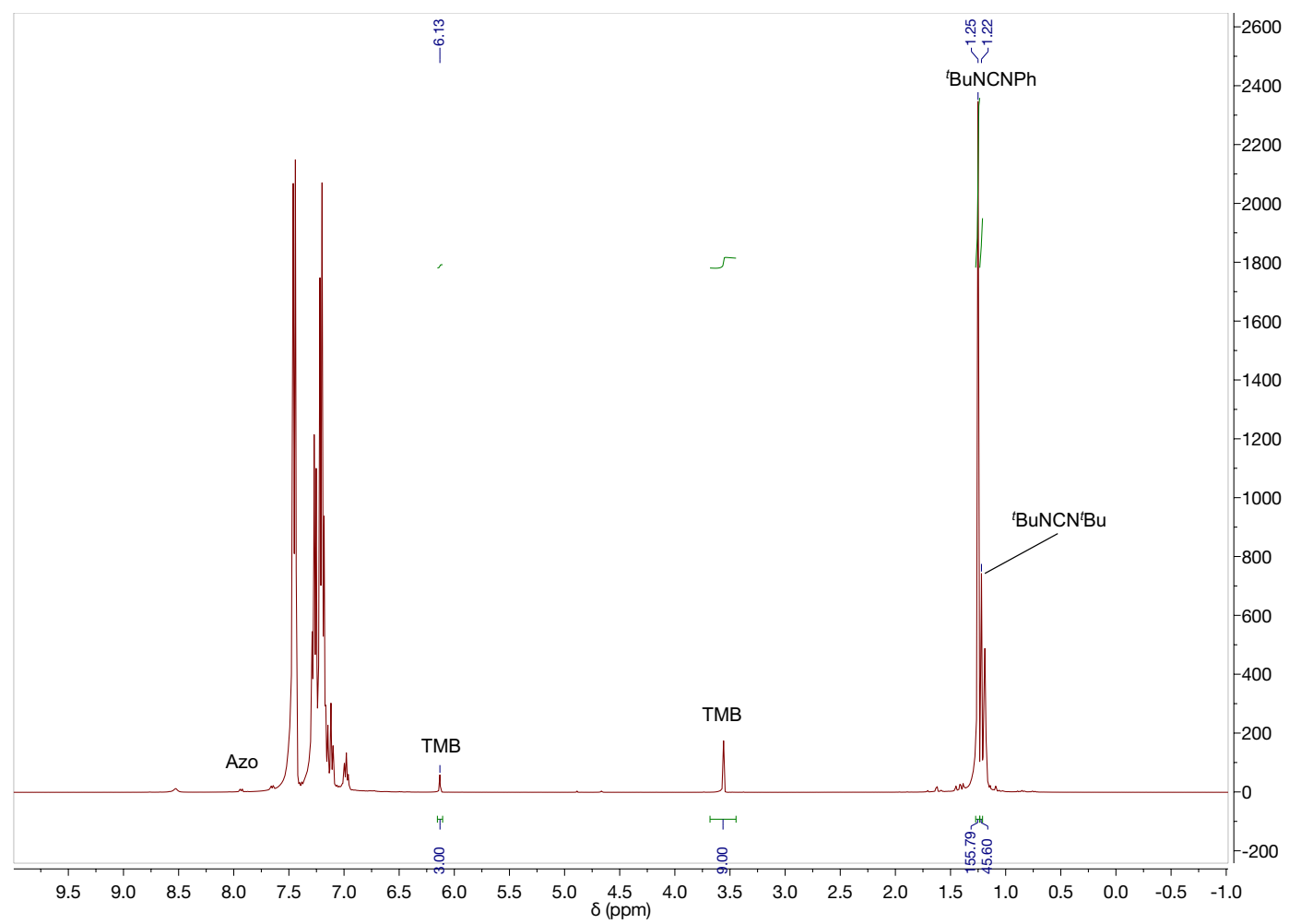

Figure S6. No-D NMR spectrum of the reaction of azobenzene and 3 equiv tertbutylisocyanide catalyzed by $\mathbf{1 d}$ at $\mathrm{t}=24 \mathrm{~h}$ in $\mathrm{PhCF}_{3}$ showing the formation of 1-tert-butyl3-phenylcarbodiimide (2a) and 1,3-di-tert-butylcarbodiimide (3). 
Catalytic reaction with azobenzene and 2,6-xylylisocyanide generating 2a' (Table 1 Entries 6-7)

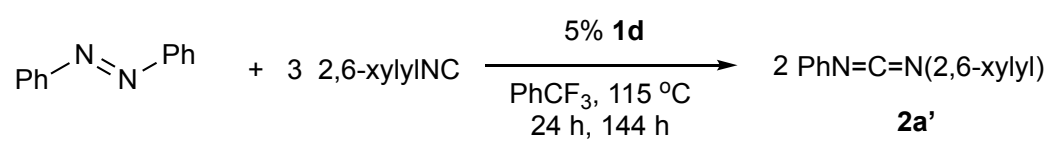

For catalytic reactions with 2,6-dimethylphenylisocyanide, $0.5 \mathrm{~mL}$ of a stock solution of $\mathrm{PhCF}_{3}$ containing $0.329 \mathrm{M}$ azobenzene (30.0 mg, $0.164 \mathrm{mmol}$ ), $0.991 \mathrm{M}$ 2,6dimethylphenyl isocyanide (65.0 mg, $0.496 \mathrm{mmol}), 0.0180 \mathrm{M}\left[\mathrm{py}_{2} \mathrm{TiBr}_{2}\left(\mathrm{~N}^{t} \mathrm{Bu}\right)\right]_{2}(7.8 \mathrm{mg}$,

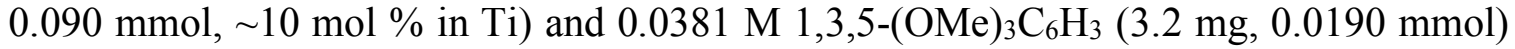
as an internal standard was prepared. In an $\mathrm{N}_{2}$ glovebox, $0.5 \mathrm{~mL}$ of the stock solution was added to a 1-dram vial containing a Teflon stir bar. The vial was sealed with a Teflon cap and removed from the glove box. The reaction was allowed to stir on a well plate (one reaction for $24 \mathrm{~h}$, a second reaction for $144 \mathrm{~h}$ ) at $115^{\circ} \mathrm{C}$. After the reaction was cooled down, an aliquot was removed from the reaction mixture, run through a plug of neutral alumina using EtOAc as eluent, and analyzed via GC-FID. Yields of $\mathbf{2 a}$ ' were determined by referencing to the internal standard, 1,3,5-(OMe $)_{3} \mathrm{C}_{6} \mathrm{H}_{3}$. 


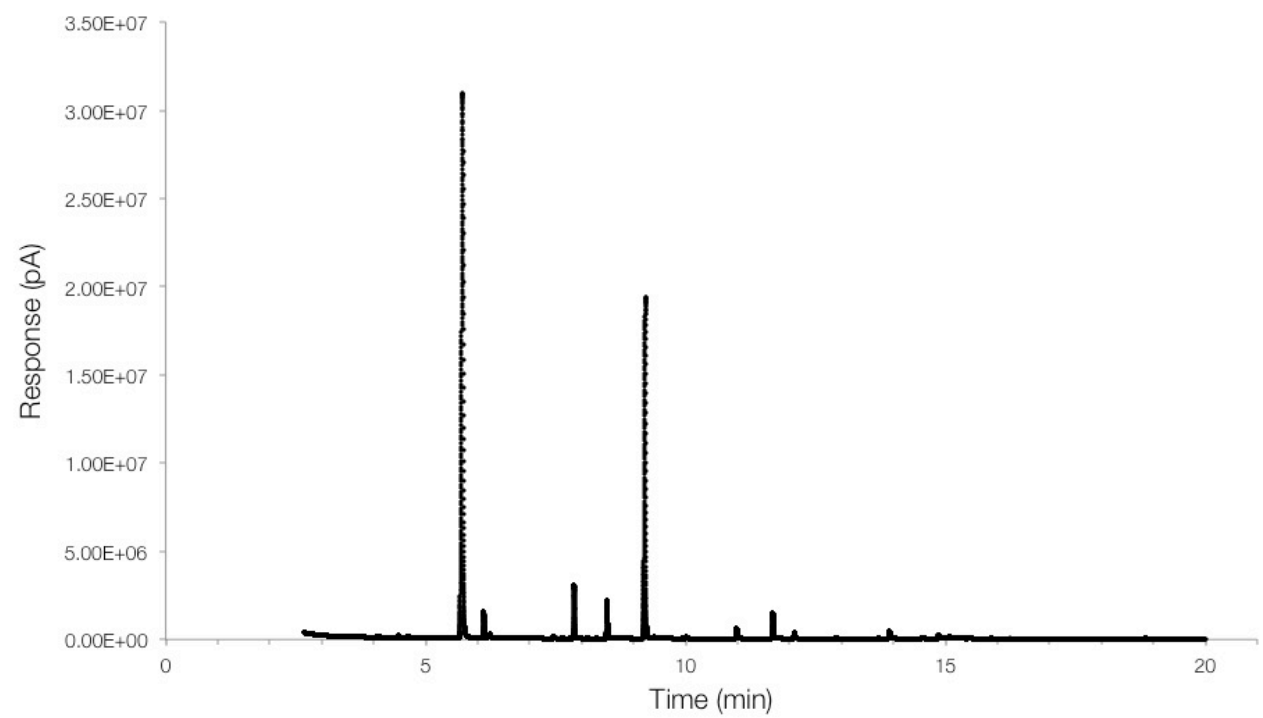

Figure S7. Chromatogram of GC-FID after catalytic reaction of azobenzene and 2,6xylylisocyanide at $\mathrm{t}=24 \mathrm{~h}$.

Table S1. Yield of 2a' via GC-FID analysis of the catalytic reaction with azobenzene and 2,6-dimethylphenylisocyanide after $24 \mathrm{~h}$.

\begin{tabular}{|c|c|c|c|c|}
\hline Compound & $\begin{array}{c}\text { Retention } \\
\text { Time } \\
\text { (min.) }\end{array}$ & Area & $\begin{array}{c}\text { Number } \\
\text { of } \\
\text { Carbons }\end{array}$ & mmol \\
\hline $1,3,5$-trimethoxybenzene & 7.858 & 475.924 & 9 & 0.019 \\
\hline $\mathrm{PhN}=\mathrm{C}=\mathrm{N}(2,6-$ Xylyl) (2a') & 10.984 & 117.669 & 15 & 0.0028 \\
\hline
\end{tabular}




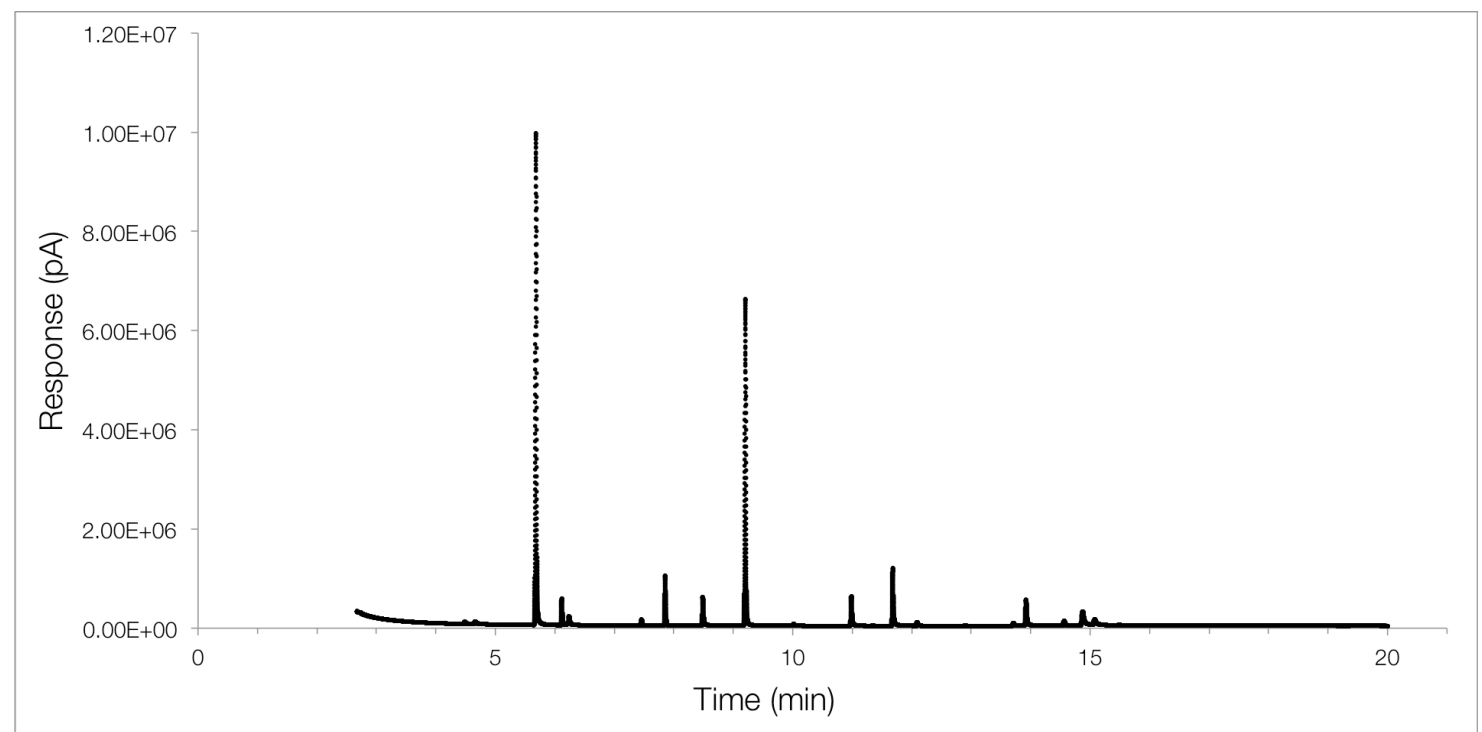

Figure S8. Chromatogram of GC-FID after catalytic reaction of azobenzene and 2,6xylylisocyanide at $\mathrm{t}=144 \mathrm{~h}$.

Table S2. Yield of 2a' via GC-FID analysis of catalytic reaction with azobenzene and 2,6dimethylphenylisocyanide after $144 \mathrm{~h}$.

\begin{tabular}{|c|c|c|c|c|}
\hline Compound & $\begin{array}{c}\text { Retention } \\
\text { Time } \\
\text { (min.) }\end{array}$ & Area & $\begin{array}{c}\text { Number } \\
\text { of } \\
\text { Carbons }\end{array}$ & mmol \\
\hline $1,3,5$-trimethoxybenzene & 7.853 & 156.611 & 9 & 0.0190 \\
\hline $\mathrm{PhN}=\mathrm{C}=\mathrm{N}(2,6-X y l y l)(\mathbf{2 a})$ & 10.983 & 118.961 & 15 & 0.0087 \\
\hline
\end{tabular}


Catalytic reaction with azobenzene and cyclohexylisocyanide generating 2a" (Table 1 Entries 8-9)

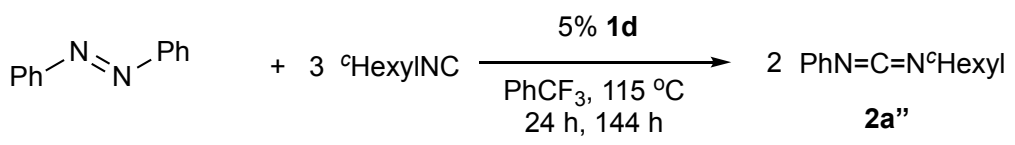

For catalytic reactions with cyclohexylisocyanide, $0.5 \mathrm{~mL}$ of a stock solution of $\mathrm{PhCF}_{3}$ containing $0.330 \mathrm{M}$ azobenzene $(30.1 \mathrm{mg}, 0.165 \mathrm{mmol}), 0.990 \mathrm{M}$ cyclohexyl isocyanide (53.9 mg, $0.496 \mathrm{mmol}), 0.0180 \mathrm{M}$ [py $\left.\mathrm{TiBr}_{2}\left(\mathrm{~N}^{t} \mathrm{Bu}\right)\right]_{2}(7.9 \mathrm{mg}, 0.090 \mathrm{mmol}, \sim 10 \mathrm{~mol} \%$ in Ti) and $0.0366 \mathrm{M} 1,3,5-(\mathrm{OMe}){ }_{3} \mathrm{C}_{6} \mathrm{H}_{3}(3.1 \mathrm{mg}, 0.0183 \mathrm{mmol})$ as an internal standard was prepared. In an $\mathrm{N}_{2}$ glovebox, $0.5 \mathrm{~mL}$ of the stock solution was added to a 1-dram vial containing a Teflon stir bar. The vial was sealed with a Teflon cap and removed from the glove box. The reaction was allowed to stir on a well plate (one reaction for $24 \mathrm{~h}$, a second reaction for $144 \mathrm{~h}$ ) at $115^{\circ} \mathrm{C}$. At each time point, an aliquot was removed from the reaction mixture, run through a plug of neutral alumina using EtOAc as eluent, and analyzed on a GC-FID. Yields of 2a" were determined by referencing to the internal standard, 1,3,5$(\mathrm{OMe}){ }_{3} \mathrm{C}_{6} \mathrm{H}_{3}$. 


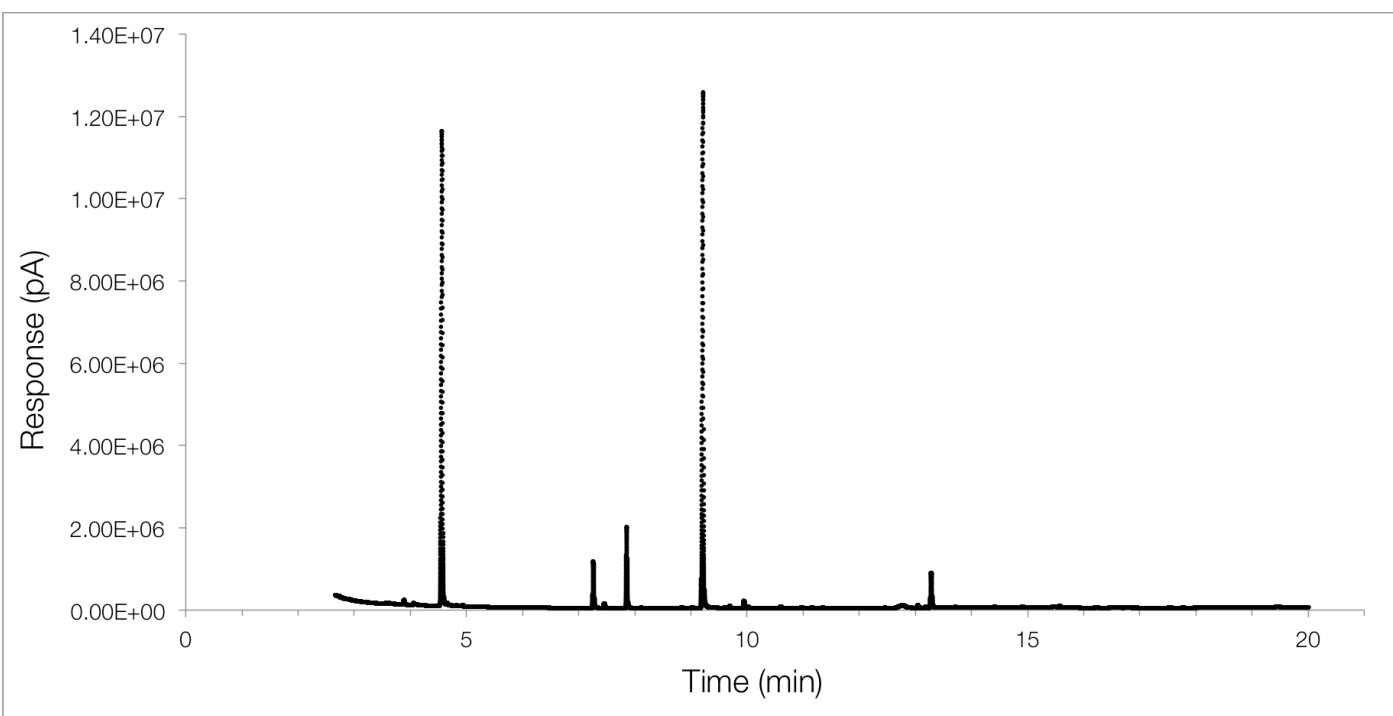

Figure S9. Chromatogram of GC-FID after catalytic reaction of azobenzene and cyclohexylisocyanide at $\mathrm{t}=24 \mathrm{~h}$.

Table S3. Yield of 2a" via GC-FID analysis of catalytic reaction with azobenzene and cyclohexylisocyanide after $24 \mathrm{~h}$.

\begin{tabular}{|c|c|c|c|c|}
\hline Compound & $\begin{array}{c}\text { Retention } \\
\text { Time } \\
\text { (min.) }\end{array}$ & Area & $\begin{array}{c}\text { Number } \\
\text { of } \\
\text { Carbons }\end{array}$ & mmol \\
\hline $1,3,5$-trimethoxybenzene & 7.856 & 304.223 & 9 & 0.0183 \\
\hline $\mathrm{PhN}=\mathrm{C}=\mathrm{N}^{c}$ Hexyl (2a') & 10.015 & 8.189 & 13 & 0.0003 \\
\hline
\end{tabular}




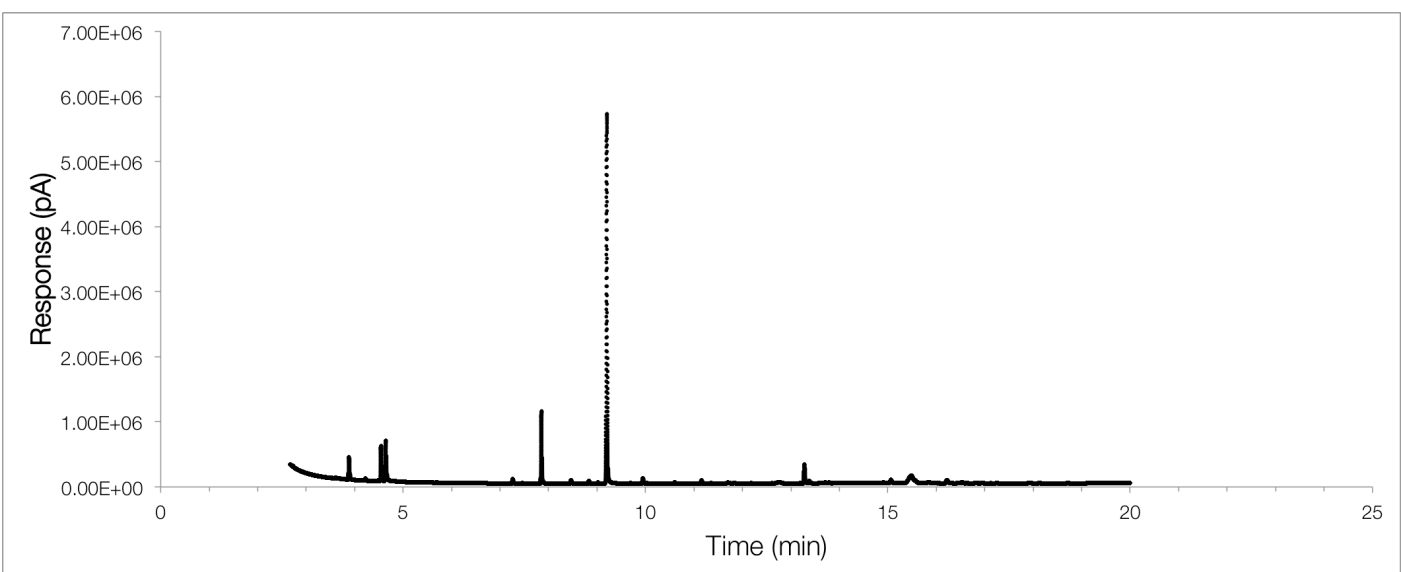

Figure S10. Chromatogram of GC-FID after catalytic reaction of azobenzene and cyclohexylisocyanide at $\mathrm{t}=144 \mathrm{~h}$.

Table S4. Yield of 2a" via for GC-FID analysis of catalytic reaction with azobenzene and cyclohexylisocyanide after $144 \mathrm{~h}$.

\begin{tabular}{|c|c|c|c|c|}
\hline Compound & $\begin{array}{c}\text { Retention } \\
\text { Time } \\
\text { (min.) }\end{array}$ & Area & $\begin{array}{c}\text { Number } \\
\text { of } \\
\text { Carbons }\end{array}$ & mmol \\
\hline 1,3,5-trimethoxybenzene & 7.853 & 175.167 & 9 & 0.0183 \\
\hline $\mathrm{PhN}=\mathrm{C}=\mathrm{N}^{c}$ Hexyl (2a') & 10.016 & 4.199 & 13 & 0.0003 \\
\hline
\end{tabular}


NMR Reactions for Table 2 (Diazene Scope):

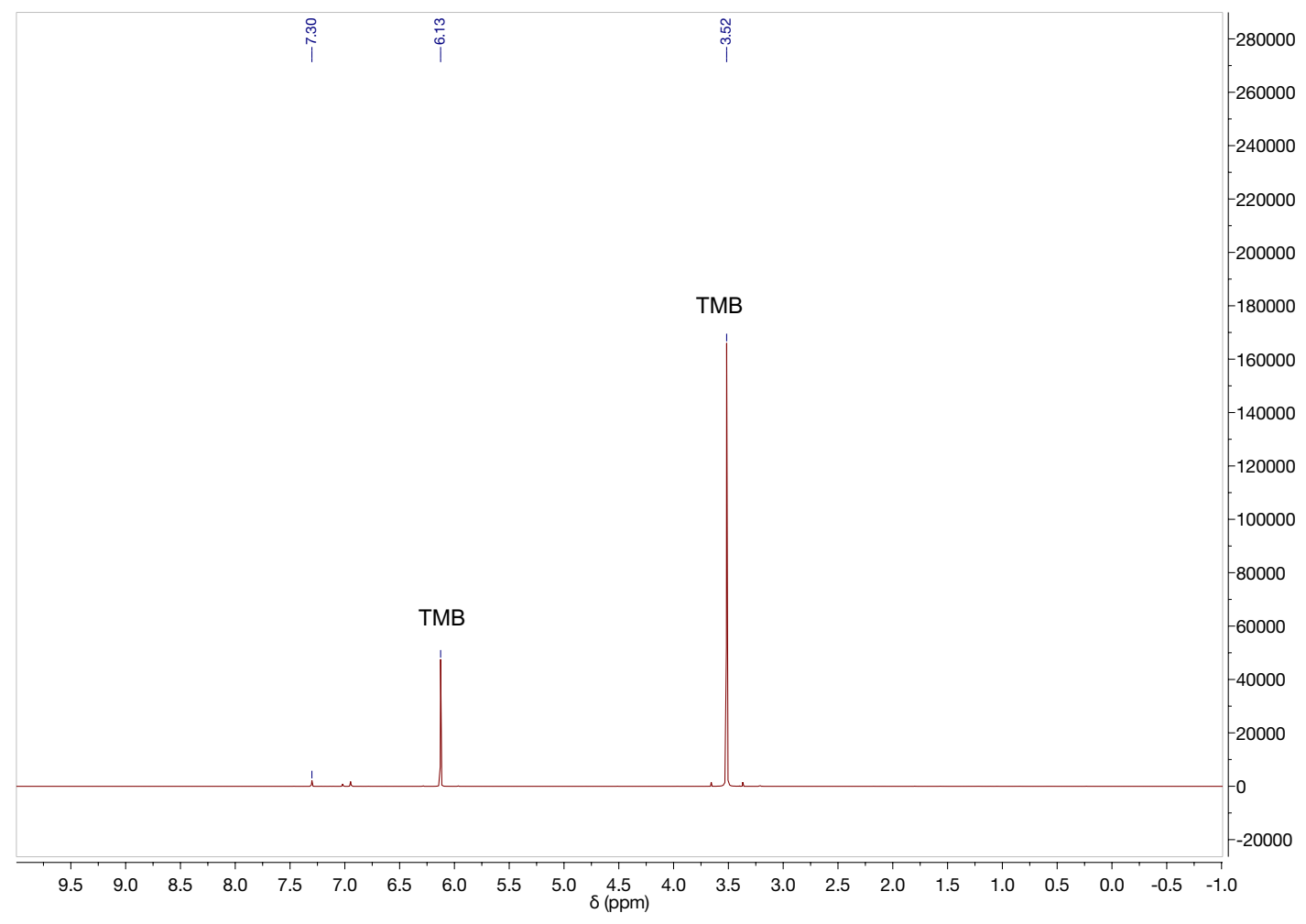

Figure S11. ${ }^{1} \mathrm{H}$ NMR spectrum of 1,3,5-trimethoxybenzene (TMB) in $\mathrm{C}_{6} \mathrm{D}_{5} \mathrm{Br}$. 
NMR tube reaction of azobenzene and tert-butylisocyanide to form 1-tert-butyl-3phenylcarbodiimide (2a) and 1,3-di-tert-butylcarbodiimide (3) (Table 2 Entry 1):

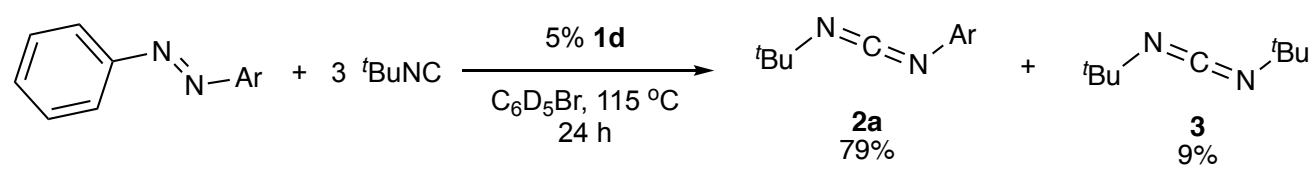

1-tert-butyl-3-phenylcarbodiimide:

${ }^{1} \mathrm{H}$ NMR $\left(500 \mathrm{MHz}, \mathrm{C}_{6} \mathrm{D}_{5} \mathrm{Br}, 27^{\circ} \mathrm{C}, \delta\right.$, ppm): 7.17 (t, $\left.2 \mathrm{H}, J=7.6 \mathrm{~Hz}, m-\mathrm{Ar}-H\right), 7.12$ (d, $2 \mathrm{H}, J=8.0 \mathrm{~Hz}, o-\mathrm{Ar}-H), 6.99(\mathrm{t}, 1 \mathrm{H}, J=7.1 \mathrm{~Hz}, p-\mathrm{Ar}-H), 1.24\left(\mathrm{~s}, 9 \mathrm{H},-\mathrm{C}\left(\mathrm{CH}_{3}\right)_{3}\right)$.

1,3-di-tert-butylcarbodiimide:

${ }^{1} \mathrm{H}$ NMR $\left(500 \mathrm{MHz}, \mathrm{C}_{6} \mathrm{D}_{5} \mathrm{Br}, 27^{\circ} \mathrm{C}, \delta, \mathrm{ppm}\right): 1.21$ (s, 18H, -C(C $\left.\left.\mathrm{CH}_{3}\right)_{3}\right)$.

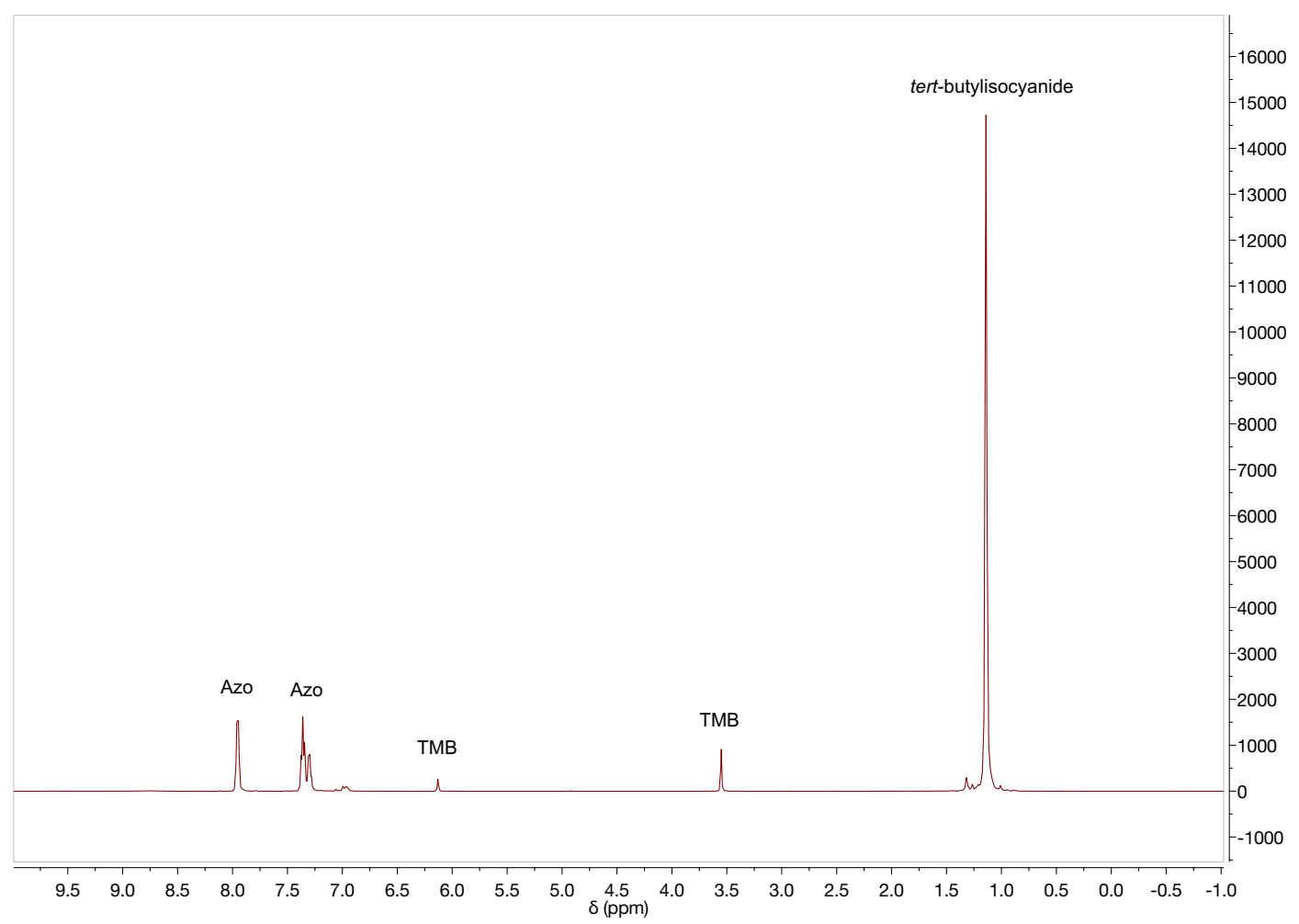

Figure S12. ${ }^{1} \mathrm{H}$ NMR spectrum of the reaction of azobenzene and tert-butylisocyanide at $\mathrm{t}$ $=0$ in $\mathrm{C}_{6} \mathrm{D}_{5} \mathrm{Br}$. 


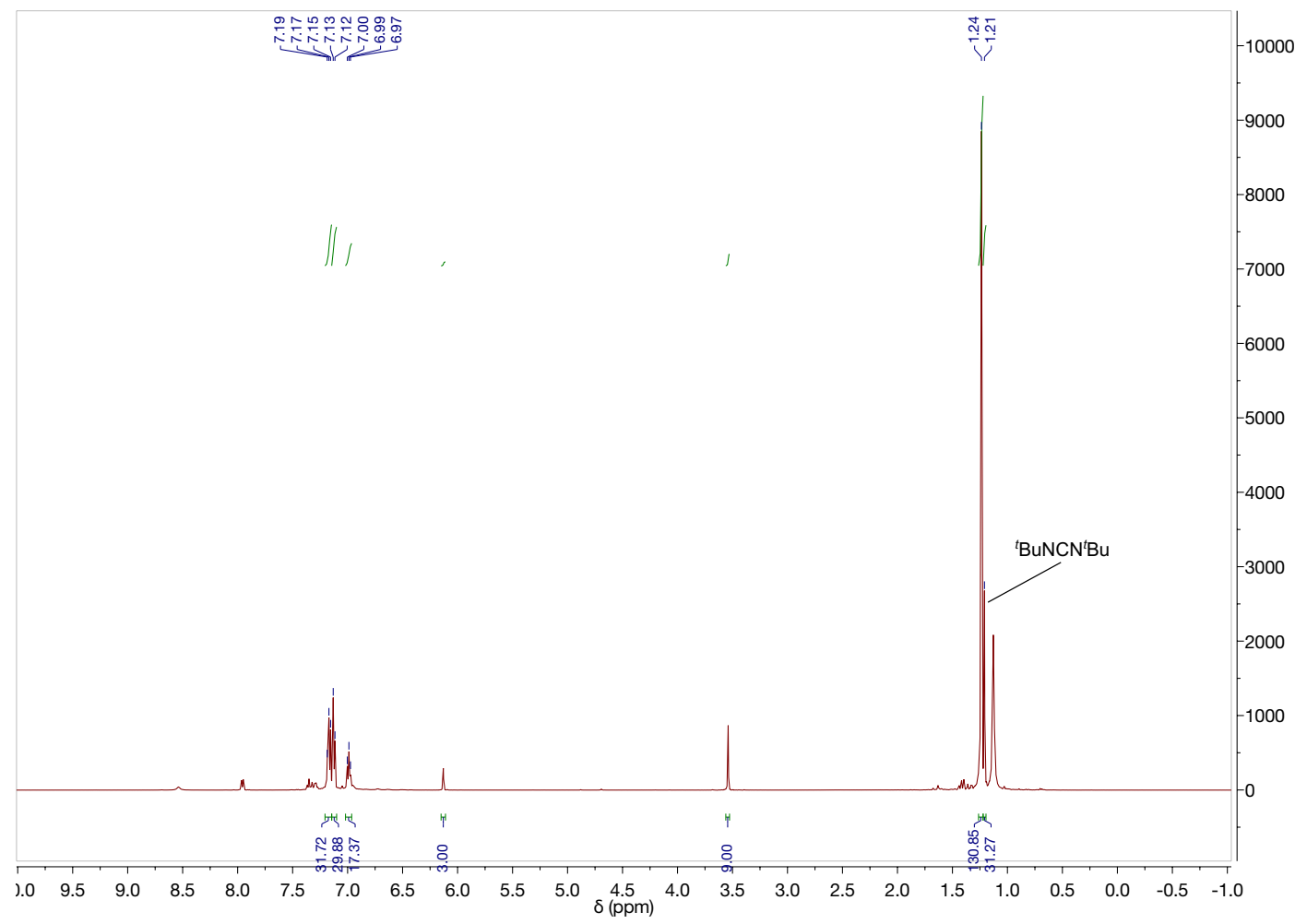

Figure S13. ${ }^{1} \mathrm{H}$ NMR spectrum of the reaction of azobenzene and tert-butylisocyanide at $\mathrm{t}$ $=24 \mathrm{~h}$ in $\mathrm{C}_{6} \mathrm{D}_{5} \mathrm{Br}$ showing the formation of 1-tert-butyl-3-phenylcarbodiimide (2a) and 1,3-di-tert-butylcarbodiimide (3). 


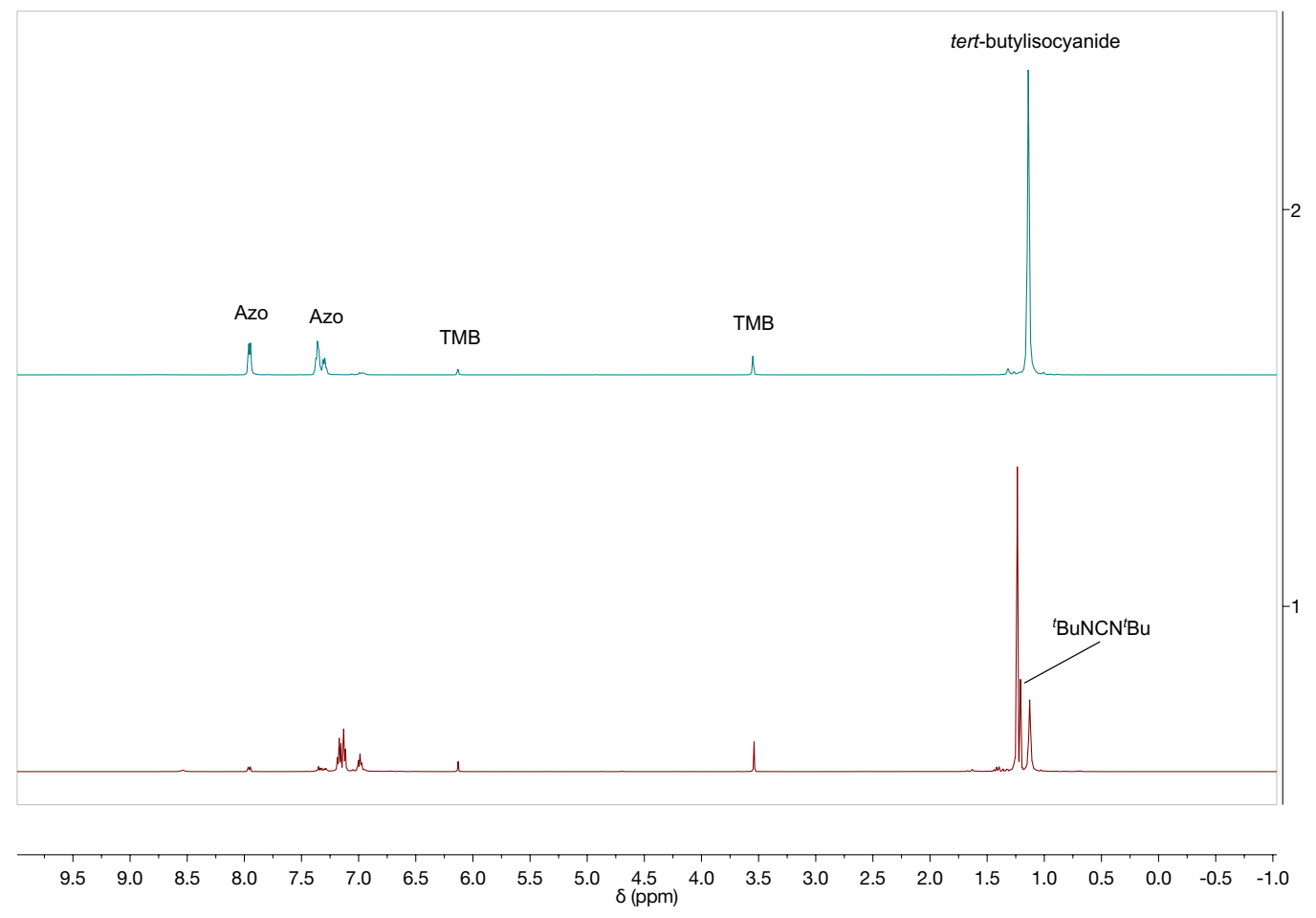

Figure S14. Stacked ${ }^{1} \mathrm{H}$ NMR spectrum of the reaction of azobenzene and tertbutylisocyanide at $\mathrm{t}=0$ (top) and $\mathrm{t}=24 \mathrm{~h}$ (bottom) in $\mathrm{C}_{6} \mathrm{D}_{5} \mathrm{Br}$ showing the formation of 1 tert-butyl-3-phenylcarbodiimide (2a) and 1,3-di-tert-butylcarbodiimide (3). 
NMR tube reaction of 1,2-di-p-tolyldiazene and tert-butylisocyanide to form 1-tert-butyl3-( $p$-tolyl)carbodiimide (2b) and 1,3-di-tert-butylcarbodiimide (3) (Table 2 Entry 2):

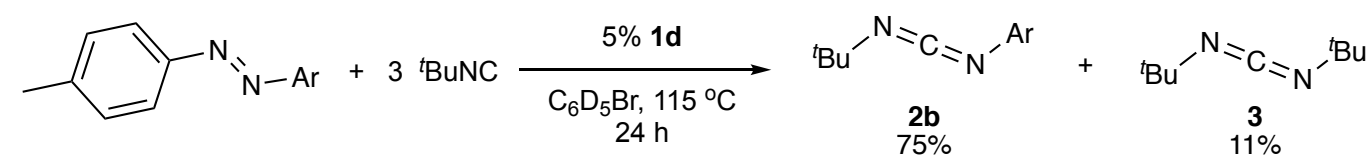

1-tert-butyl-3-( $p$-tolyl)carbodiimide:

${ }^{1} \mathrm{H}$ NMR $\left(500 \mathrm{MHz}, \mathrm{C}_{6} \mathrm{D}_{5} \mathrm{Br}, 27^{\circ} \mathrm{C}, \delta, \mathrm{ppm}\right): 7.05(\mathrm{~d}, 2 \mathrm{H}, J=8.1 \mathrm{~Hz}, \mathrm{Ar}-H), 6.96(\mathrm{~d}, 2 \mathrm{H}$, $J=8.0 \mathrm{~Hz}, \mathrm{Ar}-\mathrm{H}), 2.17$ (s, 3H, Ar-CH3), $1.26\left(\mathrm{~s}, 9 \mathrm{H},-\mathrm{C}\left(\mathrm{CH}_{3}\right)_{3}\right)$.

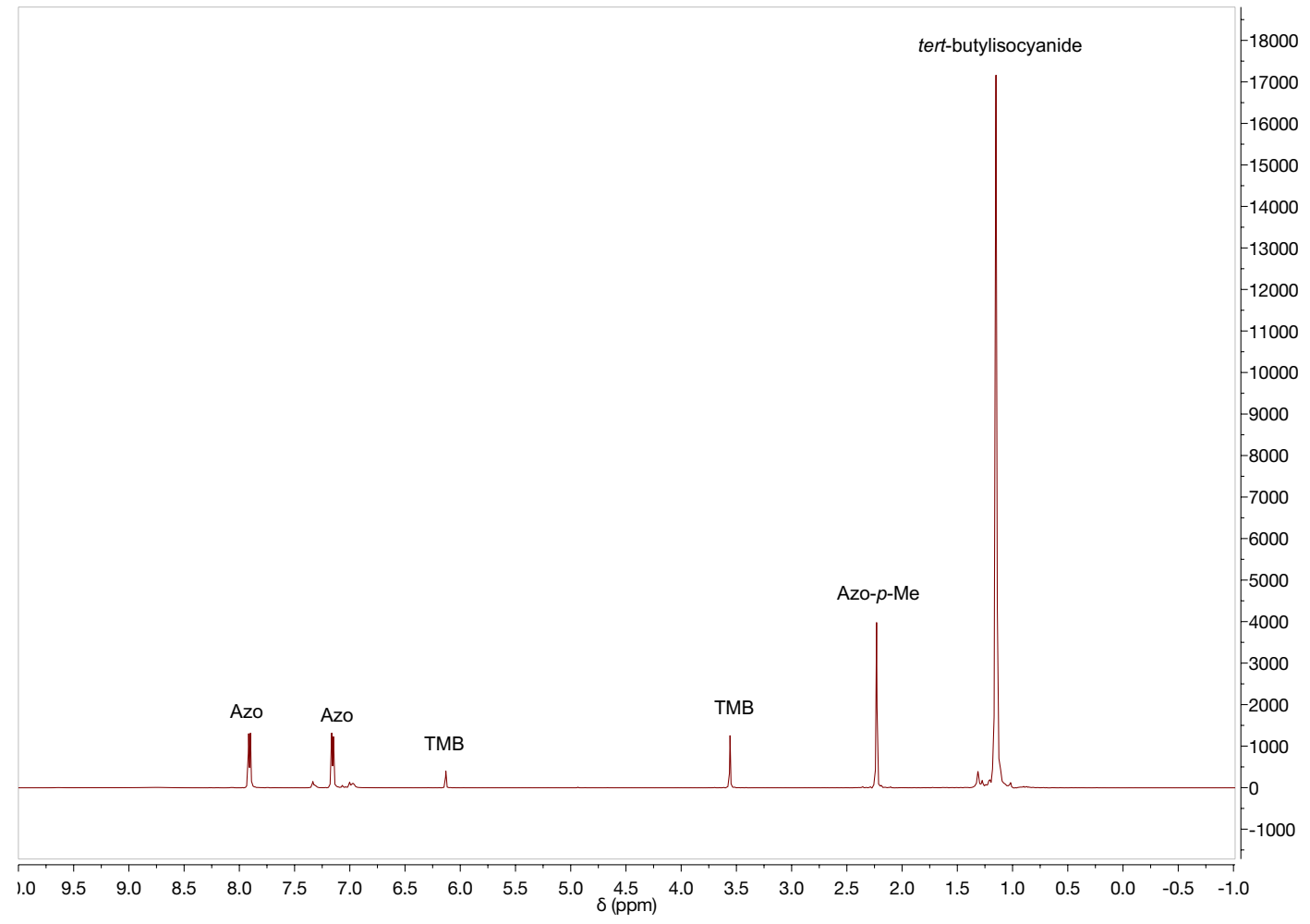

Figure S15. ${ }^{1} \mathrm{H}$ NMR spectrum of the reaction of 1,2-di-p-tolyldiazene and tertbutylisocyanide at $\mathrm{t}=0$ in $\mathrm{C}_{6} \mathrm{D}_{5} \mathrm{Br}$. The concentration of diazene is low due to its poor solubility at the start of the reaction. 


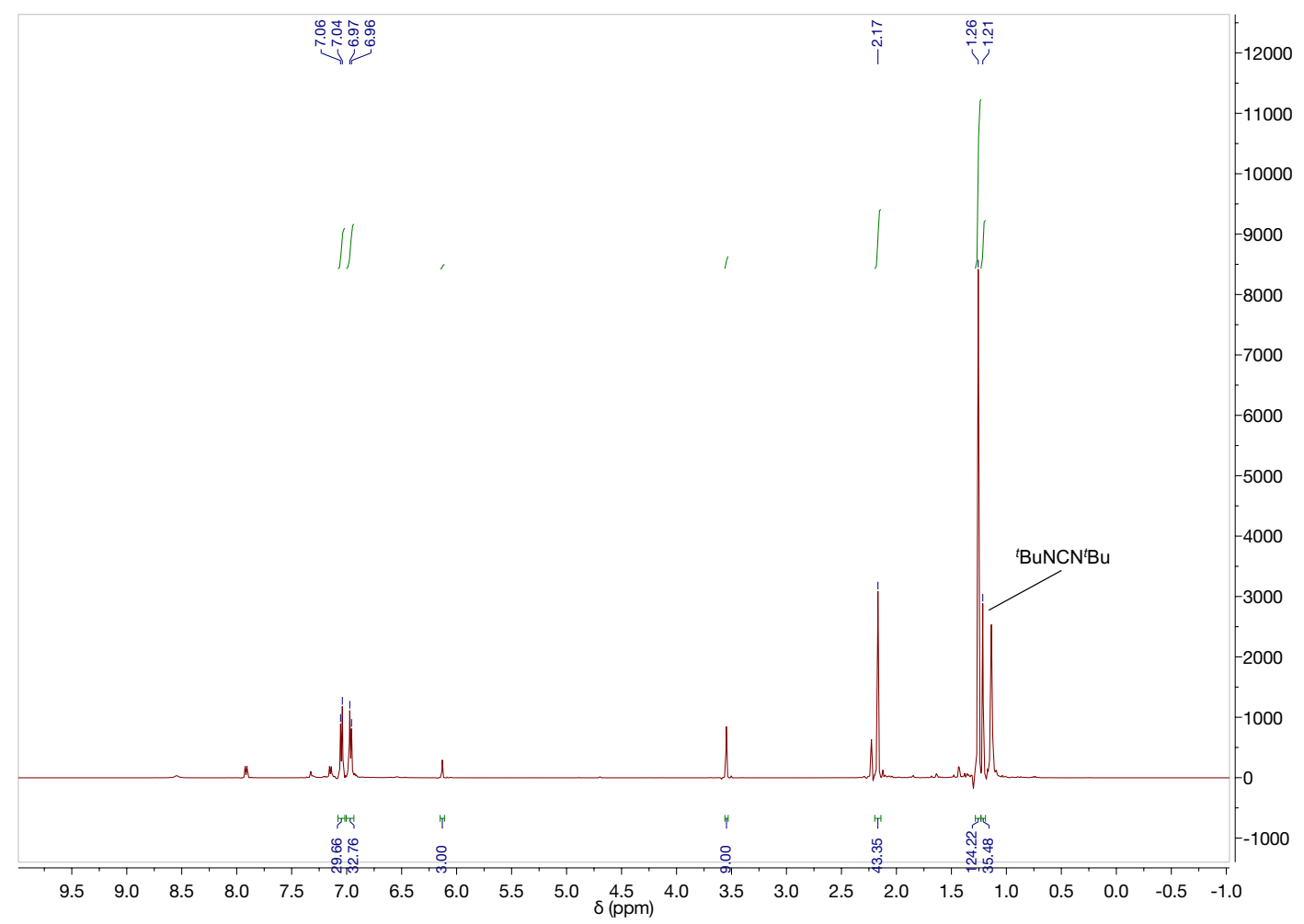

Figure S16. ${ }^{1} \mathrm{H}$ NMR spectrum of the reaction of 1,2-di-p-tolyldiazene and tertbutylisocyanide at $\mathrm{t}=24 \mathrm{~h}$ in $\mathrm{C}_{6} \mathrm{D}_{5} \mathrm{Br}$ showing the formation of 1-tert-butyl-3- $(p$ tolyl)carbodiimide (2b) and 1,3-di-tert-butylcarbodiimide (3). Notably, the are no further tolyl $\mathrm{CH}_{3}$ resonances that could be ascribed to $\mathrm{ArN}=\mathrm{C}=\mathrm{NAr}$ or $\mathrm{ArNC}$." 


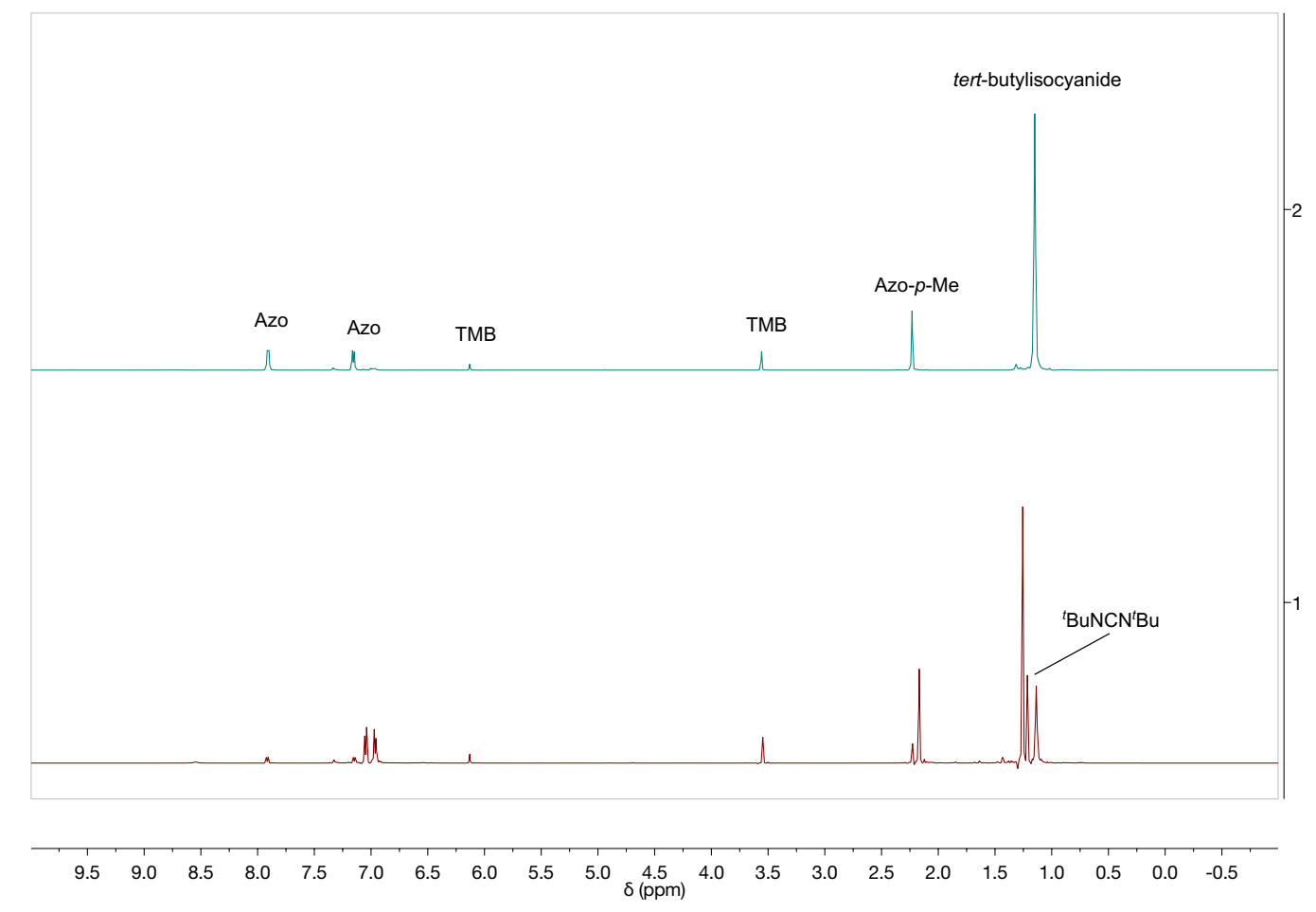

Figure S17. Stacked ${ }^{1} \mathrm{H}$ NMR spectrum of the reaction of 1,2-di-p-tolyldiazene and tertbutylisocyanide at $\mathrm{t}=0$ (top) and $\mathrm{t}=24 \mathrm{~h}$ (bottom) in $\mathrm{C}_{6} \mathrm{D}_{5} \mathrm{Br}$ showing the formation of 1tert-butyl-3-( $p$-tolyl)carbodiimide (2b) and 1,3-di-tert-butylcarbodiimide (3). 
NMR tube reaction of 1,2-bis(4-fluorophenyl)diazene and tert-butylisocyanide to form 1tert-butyl-3-(4-fluorophenyl)carbodiimide (2c) and 1,3-di-tert-butylcarbodiimide (3) (Table 2 Entry 3):

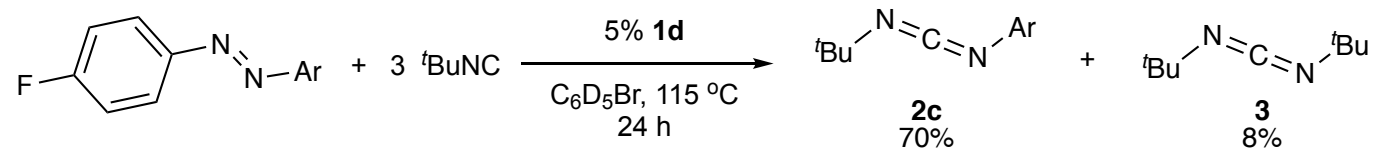

1-tert-butyl-3-(4-fluorophenyl)carbodiimide:

${ }^{1} \mathrm{H}$ NMR $\left(500 \mathrm{MHz}, \mathrm{C}_{6} \mathrm{D}_{5} \mathrm{Br}, 27{ }^{\circ} \mathrm{C}, \delta, \mathrm{ppm}\right): 6.99$ (dd, $\left.2 \mathrm{H}, J=8.6,4.8 \mathrm{~Hz}, \mathrm{Ar}-H\right), 6.83$ (app t, $2 \mathrm{H}, J=8.5 \mathrm{~Hz}, \mathrm{Ar}-\mathrm{H}), 1.24\left(\mathrm{~s}, 9 \mathrm{H},-\mathrm{C}\left(\mathrm{CH}_{3}\right)_{3}\right)$.

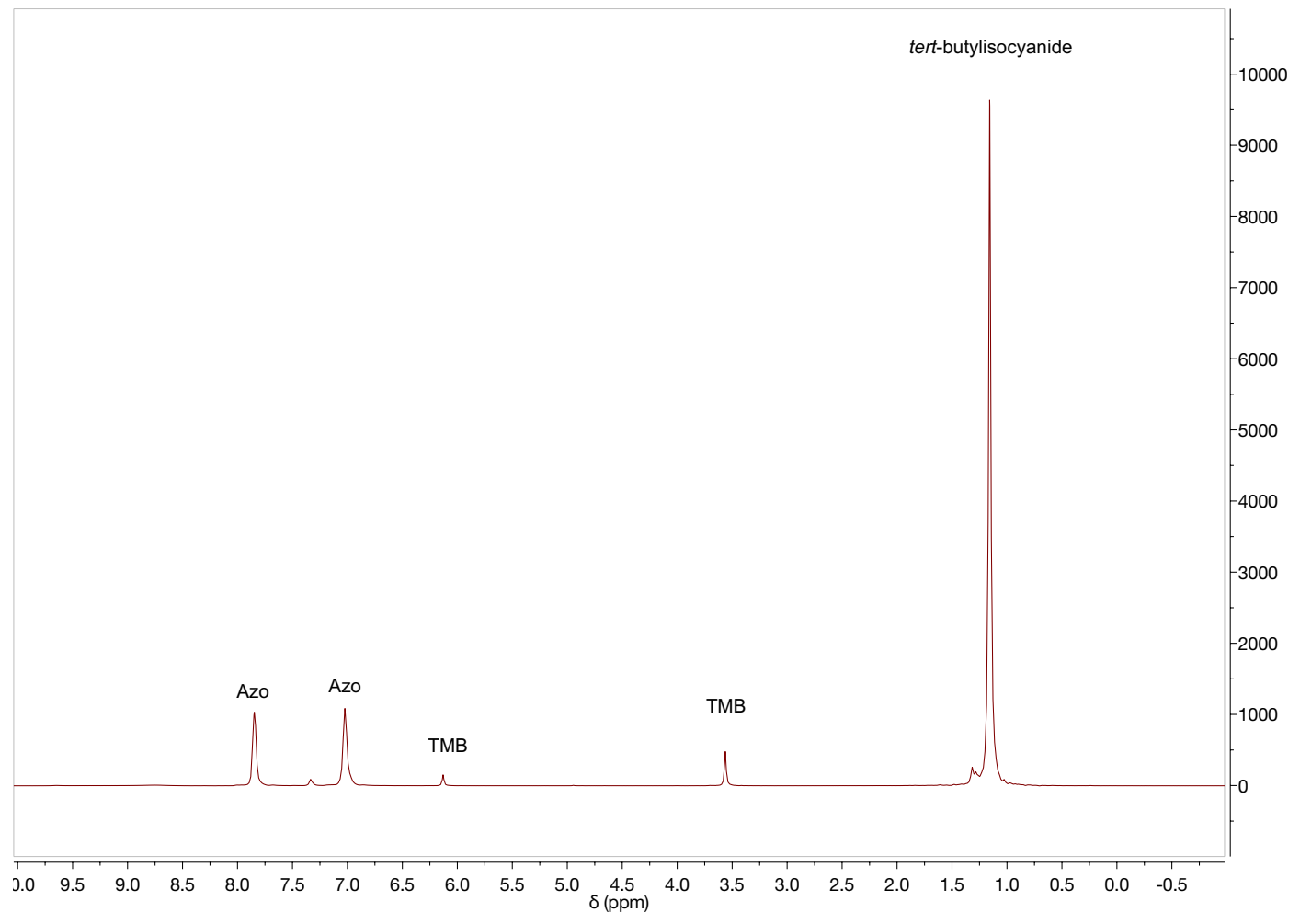

Figure S18. ${ }^{1} \mathrm{H}$ NMR spectrum of the reaction of 1,2-bis(4-fluorophenyl)diazene and tertbutylisocyanide at $\mathrm{t}=0$ in $\mathrm{C}_{6} \mathrm{D}_{5} \mathrm{Br}$. 


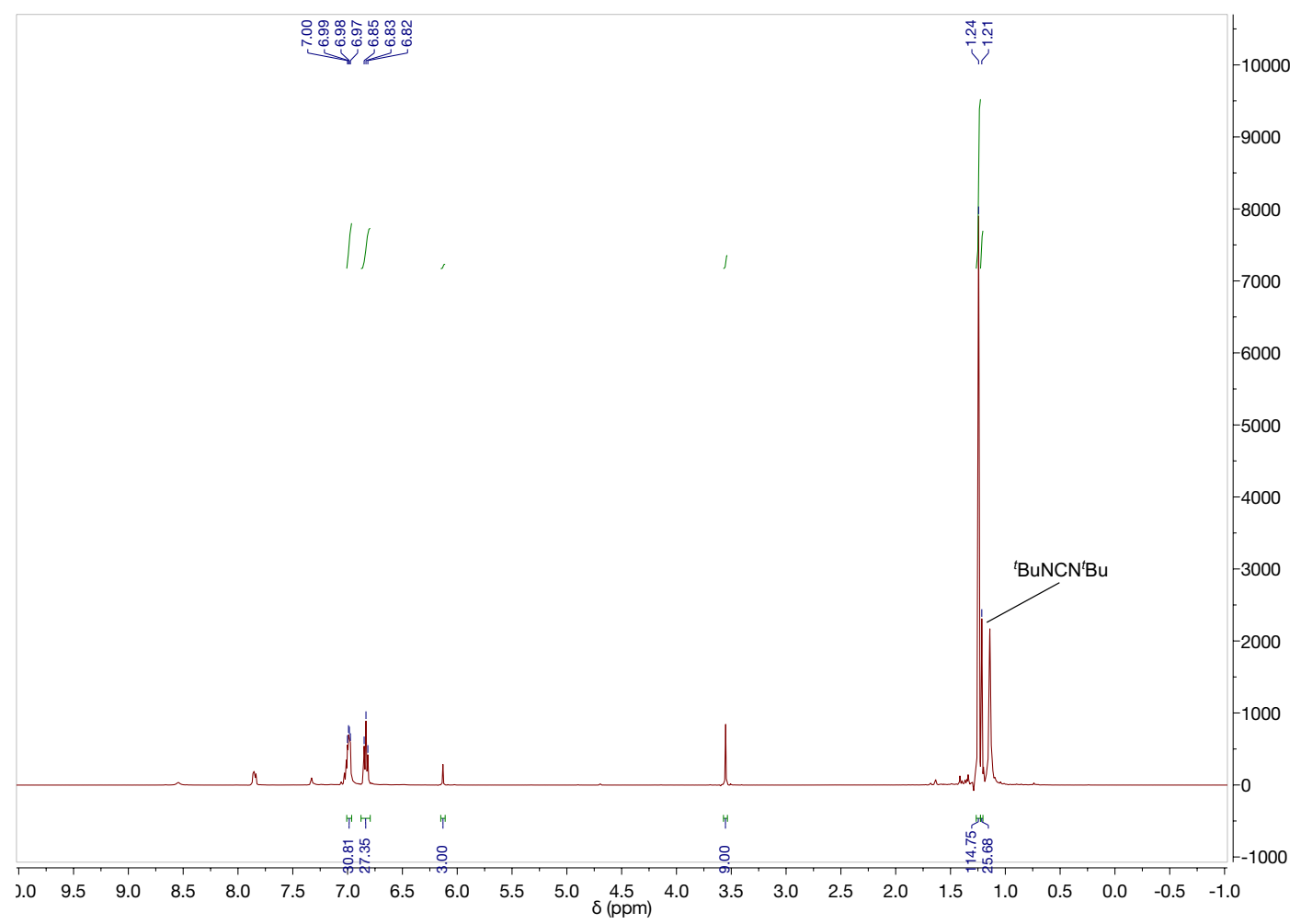

Figure S19. ${ }^{1} \mathrm{H}$ NMR spectrum of the reaction of 1,2-bis(4-fluorophenyl)diazene and tertbutylisocyanide at $\mathrm{t}=24 \mathrm{~h}$ in $\mathrm{C}_{6} \mathrm{D}_{5} \mathrm{Br}$ showing the formation of 1-tert-butyl-3-(4fluorophenyl)carbodiimide (2c) and 1,3-di-tert-butylcarbodiimide (3). 


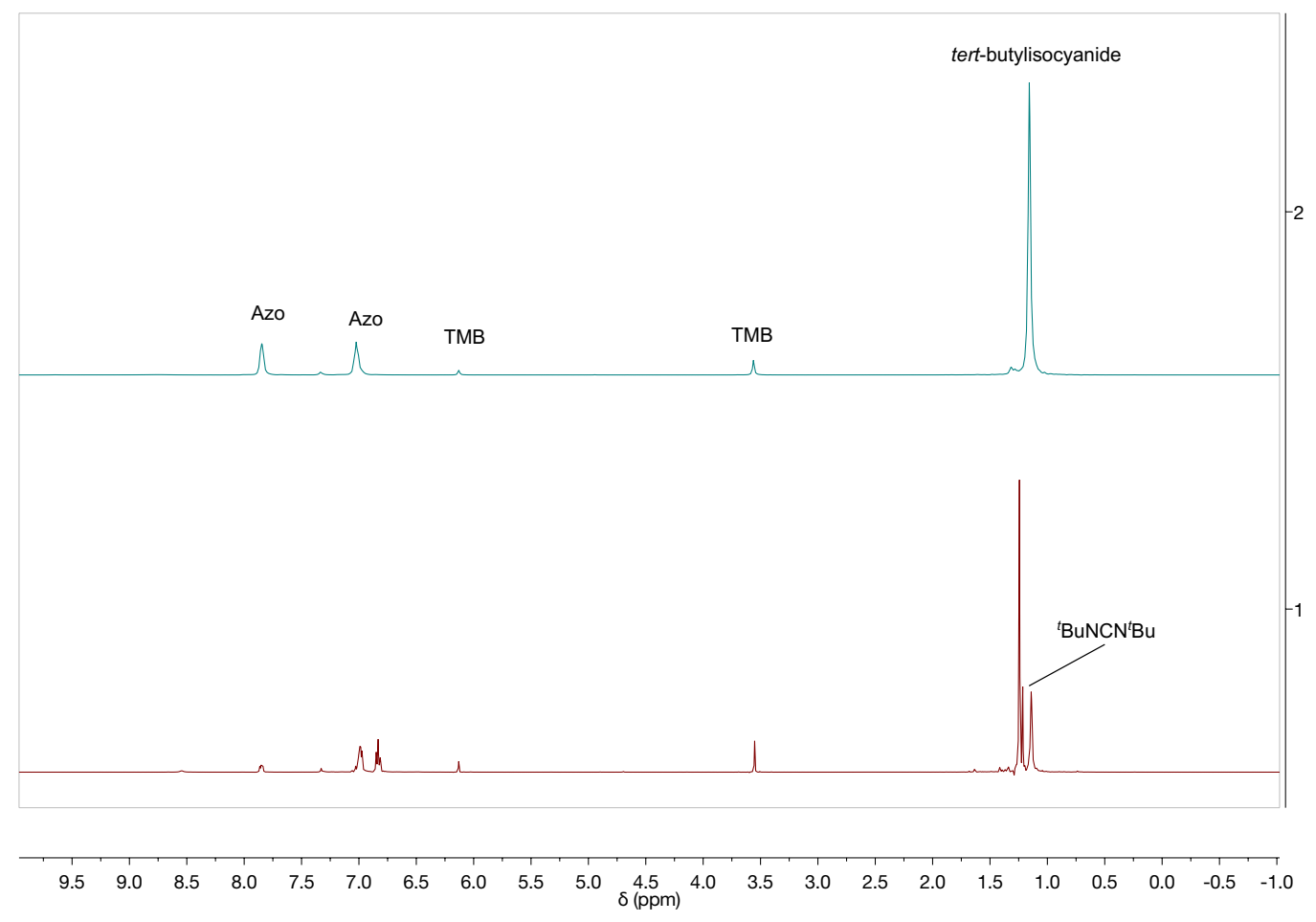

Figure S20. Stacked ${ }^{1} \mathrm{H}$ NMR spectrum of the reaction of 1,2-bis(4-fluorophenyl)diazene and tert-butylisocyanide at $\mathrm{t}=0$ (top) and $\mathrm{t}=24 \mathrm{~h}$ (bottom) in $\mathrm{C}_{6} \mathrm{D}_{5} \mathrm{Br}$ showing the formation of 1-tert-butyl-3-(4-fluorophenyl)carbodiimide (2c) and 1,3-di-tertbutylcarbodiimide (3). 
NMR tube reaction of 1,2-bis(4-chlorophenyl)diazene and tert-butylisocyanide to form 1tert-butyl-3-(4-chlorophenyl)carbodiimide (2d) and 1,3-di-tert-butylcarbodiimide (3) (Table 2 Entry 4):

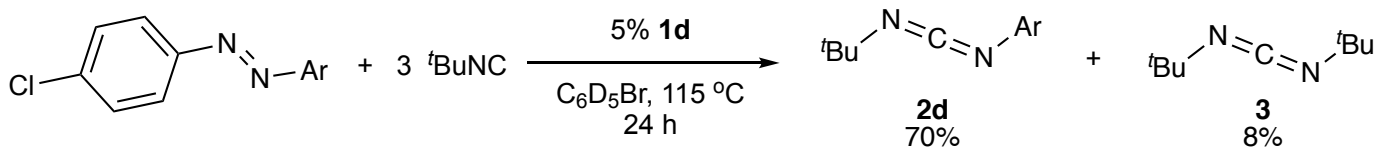

1-tert-butyl-3-(4-chlorophenyl)carbodiimide:

${ }^{1} \mathrm{H}$ NMR $\left(500 \mathrm{MHz}, \mathrm{C}_{6} \mathrm{D}_{5} \mathrm{Br}, 27{ }^{\circ} \mathrm{C}, \delta, \mathrm{ppm}\right): 7.10(\mathrm{~d}, 2 \mathrm{H}, J=8.4 \mathrm{~Hz}, \mathrm{Ar}-H), 6.95$ (d, 2H, $J=8.5 \mathrm{~Hz}, \mathrm{Ar}-\mathrm{H}), 1.24\left(\mathrm{~s}, 9 \mathrm{H},-\mathrm{C}\left(\mathrm{CH}_{3}\right)_{3}\right)$.

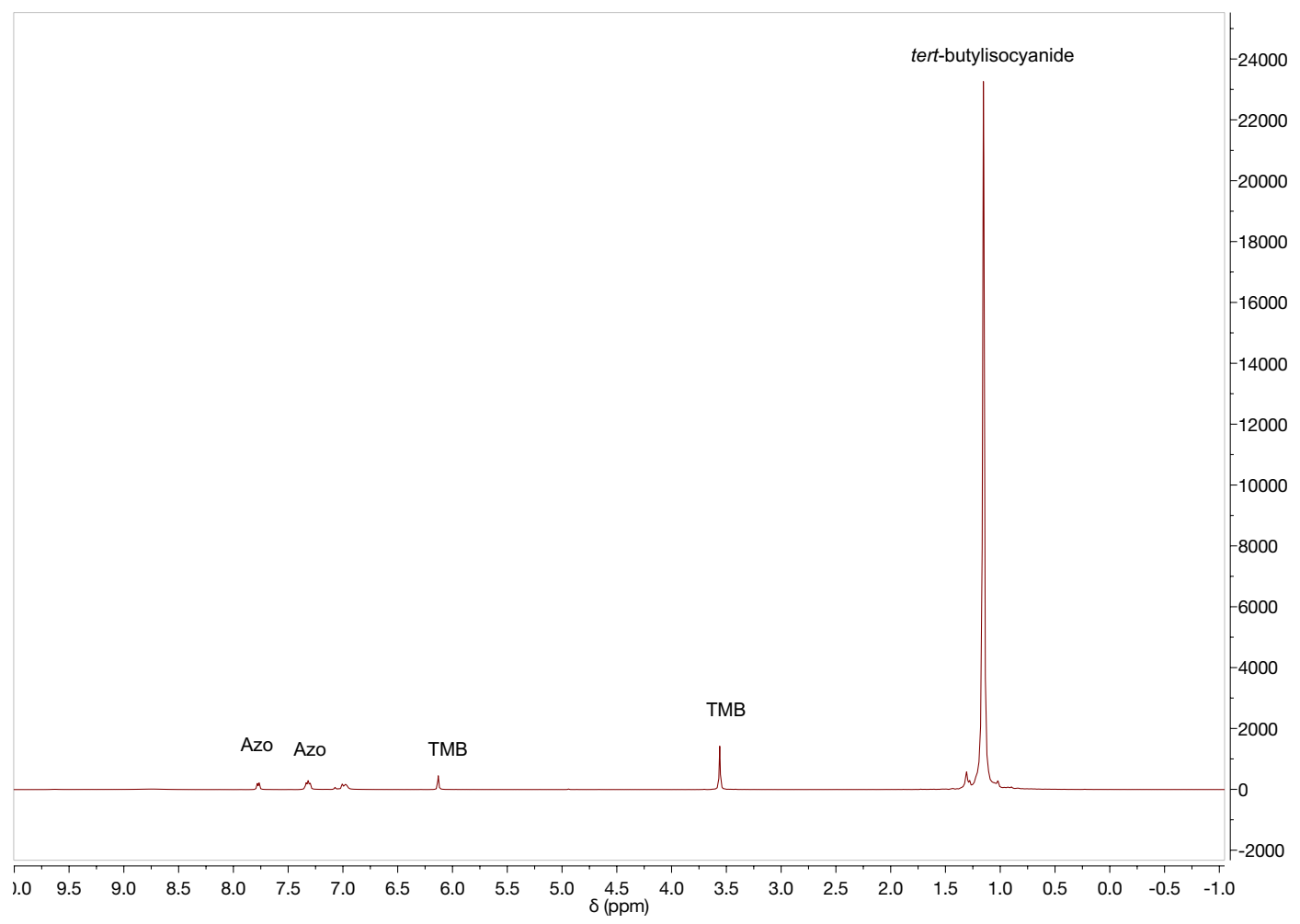

Figure S21. ${ }^{1} \mathrm{H}$ NMR spectrum of the reaction of 1,2-bis(4-chlorophenyl)diazene and tertbutylisocyanide at $\mathrm{t}=0$ in $\mathrm{C}_{6} \mathrm{D}_{5} \mathrm{Br}$. The concentration of diazene is low due to its poor solubility at the start of the reaction. 


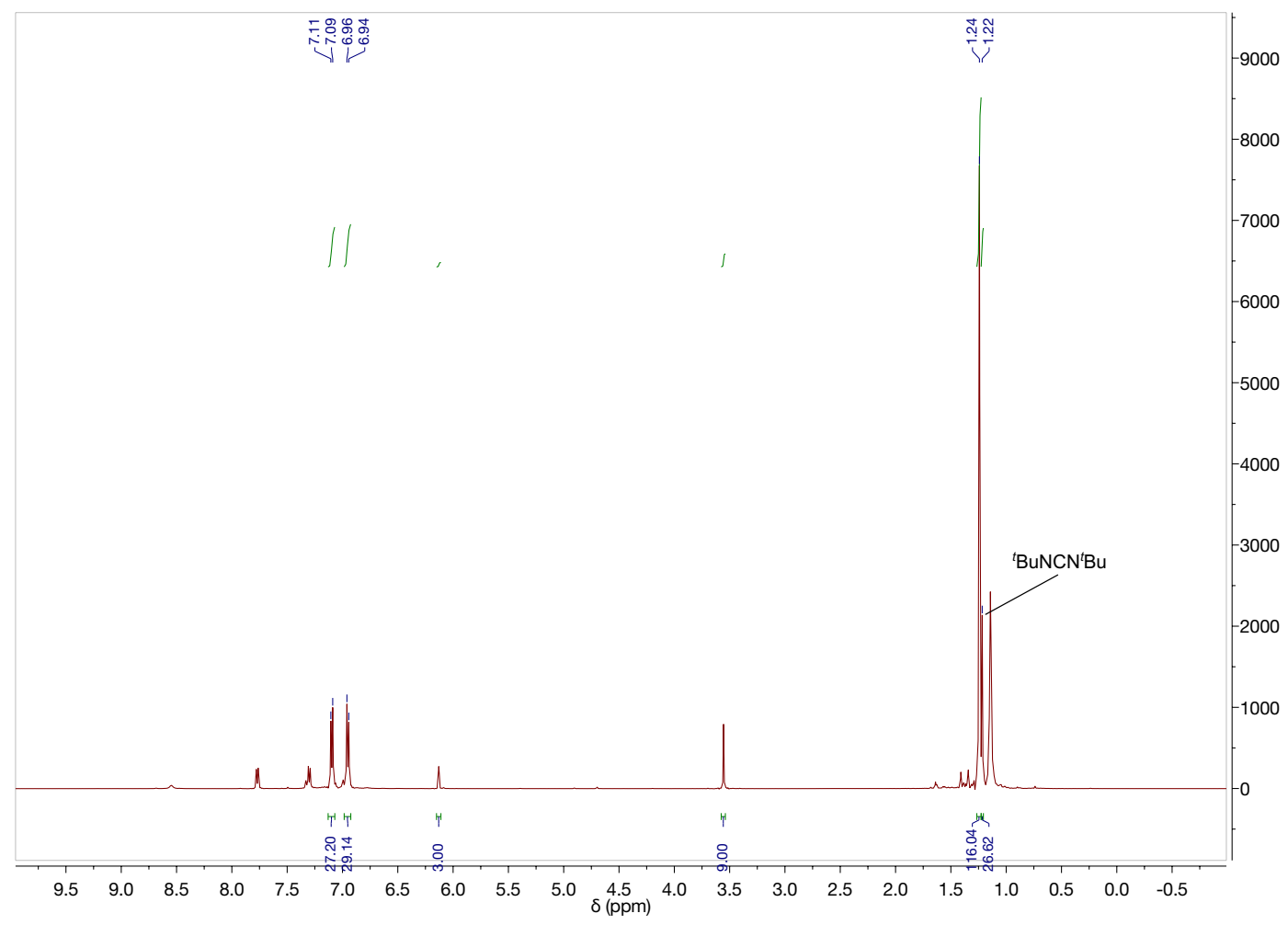

Figure S22. ${ }^{1} \mathrm{H}$ NMR spectrum of the reaction of 1,2-bis(4-chlorophenyl)diazene and tertbutylisocyanide at $\mathrm{t}=24 \mathrm{~h}$ in $\mathrm{C}_{6} \mathrm{D}_{5} \mathrm{Br}$ showing the formation of 1-tert-butyl-3-(4chlorophenyl)carbodiimide (2d) and 1,3-di-tert-butylcarbodiimide (3). 


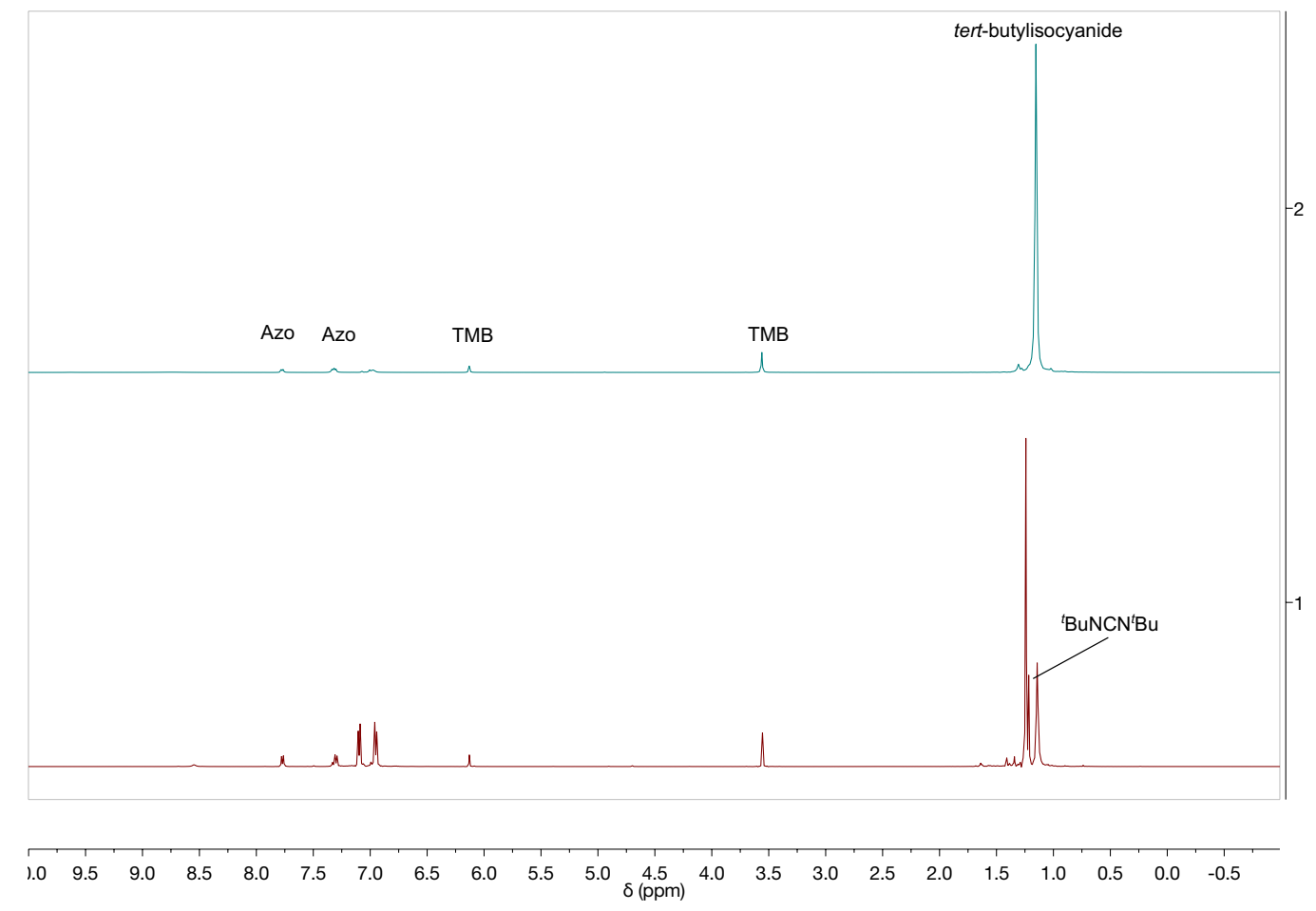

Figure S23. Stacked ${ }^{1} \mathrm{H}$ NMR spectrum of the reaction of 1,2-bis(4-chlorophenyl)diazene and tert-butylisocyanide at $\mathrm{t}=0$ (top) and $\mathrm{t}=24 \mathrm{~h}$ (bottom) in $\mathrm{C}_{6} \mathrm{D}_{5} \mathrm{Br}$ showing the formation of 1-tert-butyl-3-(4-chlorophenyl)carbodiimide (2d) and 1,3-di-tertbutylcarbodiimide (3). 
NMR tube reaction of 1,2-bis(4-(trifluoromethoxy)phenyl)diazene and tertbutylisocyanide to form 1-tert-butyl-3-(4-(trifluoromethoxy)phenyl))carbodiimide (2e) and 1,3-di-tert-butylcarbodiimide (3) (Table 2 Entry 5):

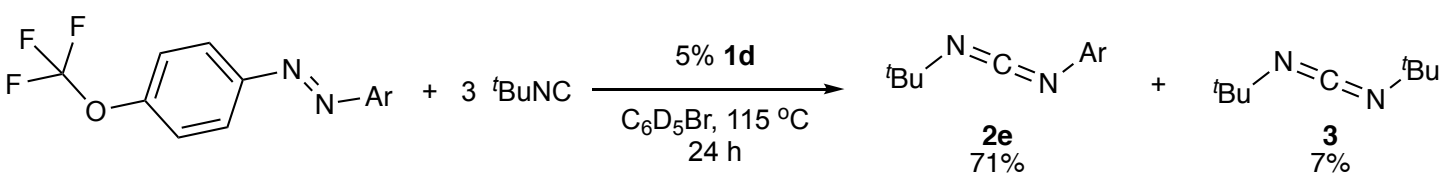

1-tert-butyl-3-(4-(trifluoromethoxy)phenyl))carbodiimide:

${ }^{1} \mathrm{H}$ NMR (500 MHz, $\mathrm{C}_{6} \mathrm{D}_{5} \mathrm{Br}, 27{ }^{\circ} \mathrm{C}, \delta$, ppm): 7.03-6.95 (m, 4H, Ar-H), 1.25 (s, 9H, $\left.\mathrm{C}\left(\mathrm{CH}_{3}\right)_{3}\right)$.

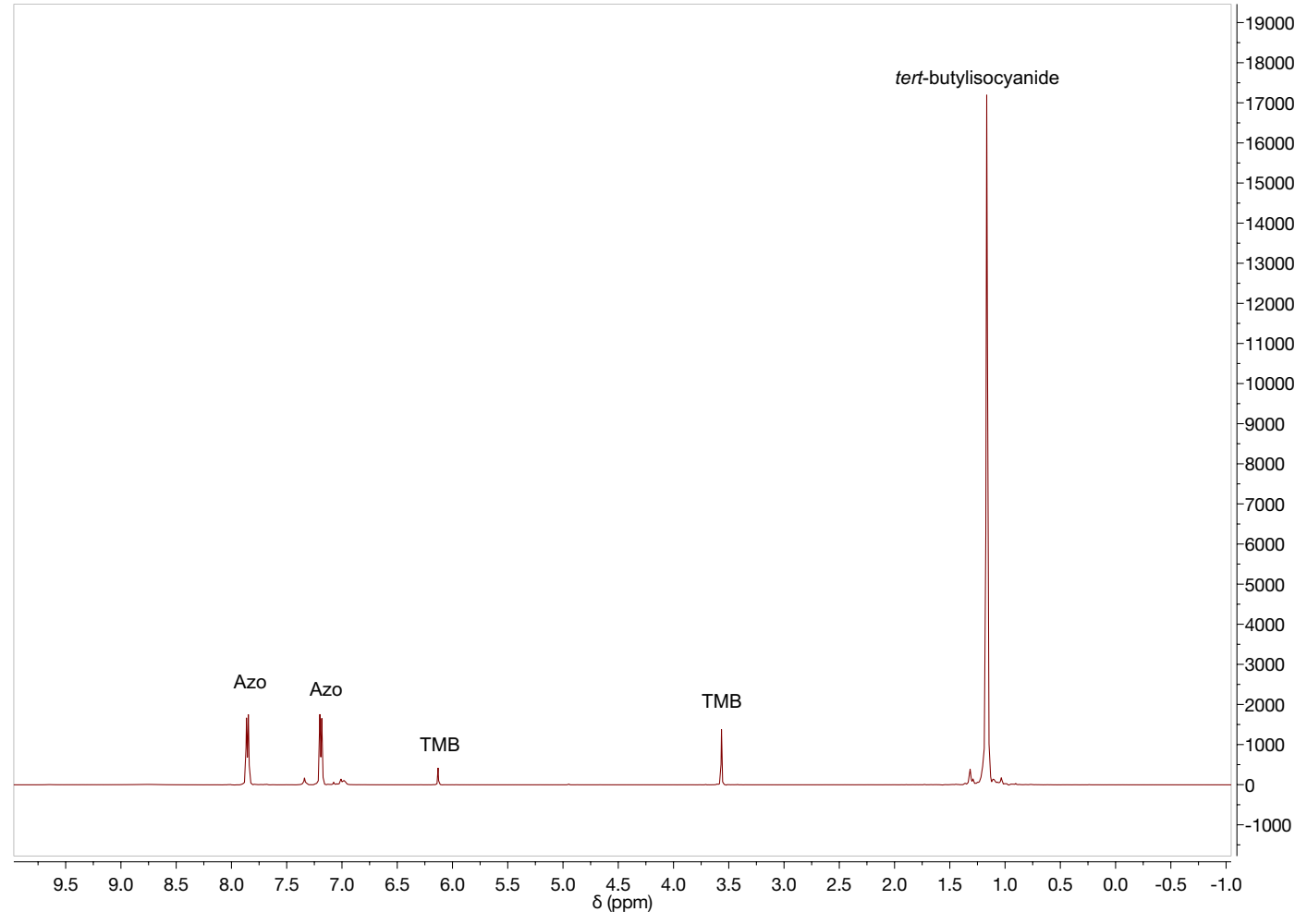

Figure S24. ${ }^{1} \mathrm{H}$ NMR spectrum of the reaction of 1,2-bis(4(trifluoromethoxy)phenyl)diazene and tert-butylisocyanide at $\mathrm{t}=0$ in $\mathrm{C}_{6} \mathrm{D}_{5} \mathrm{Br}$. 


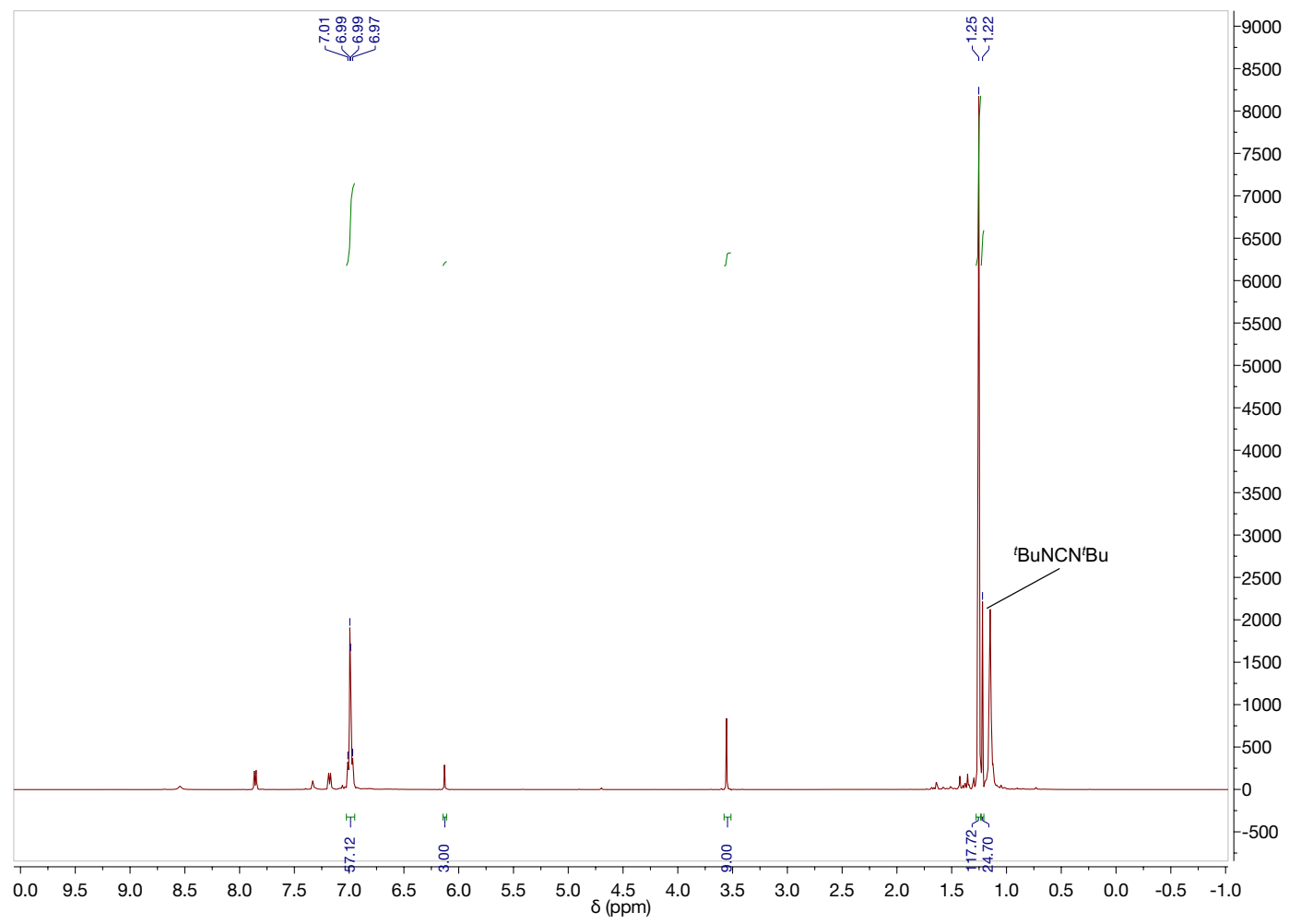

Figure S25. ${ }^{1} \mathrm{H} \quad \mathrm{NMR}$ spectrum of the reaction of 1,2-bis(4(trifluoromethoxy)phenyl)diazene and tert-butylisocyanide at $\mathrm{t}=24 \mathrm{~h}$ in $\mathrm{C}_{6} \mathrm{D}_{5} \mathrm{Br}$ showing the formation of 1-tert-butyl-3-(4-(trifluoromethoxy)phenyl))carbodiimide (2e) and 1,3-ditert-butylcarbodiimide (3). 


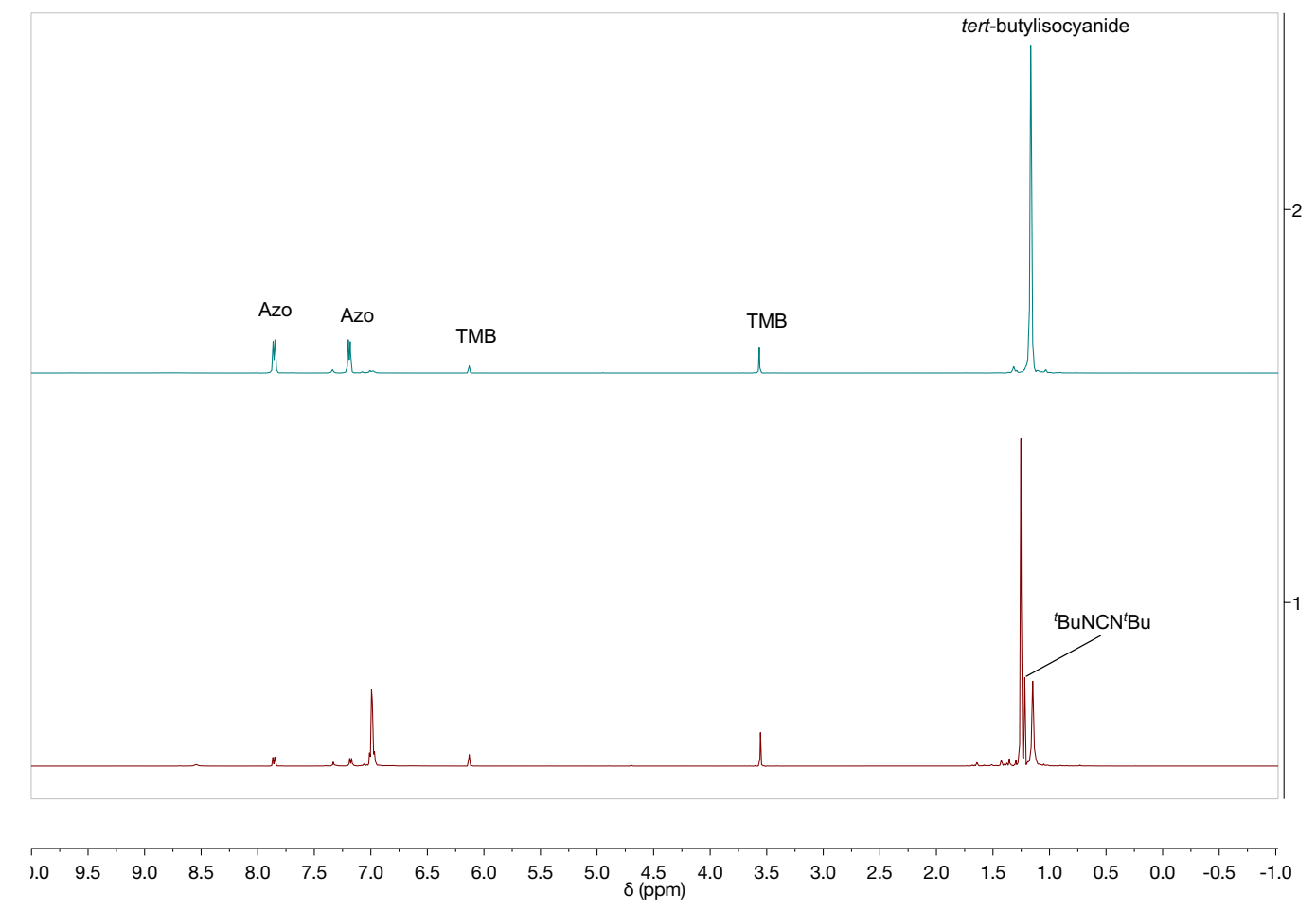

Figure S26. Stacked ${ }^{1} \mathrm{H}$ NMR spectrum of the reaction of 1,2-bis(4(trifluoromethoxy)phenyl)diazene and tert-butylisocyanide at $\mathrm{t}=0$ (top) and $\mathrm{t}=24 \mathrm{~h}$ (bottom) in $\mathrm{C}_{6} \mathrm{D}_{5} \mathrm{Br}$ showing the formation of 1-tert-butyl-3-(4(trifluoromethoxy)phenyl))carbodiimide (2e) and 1,3-di-tert-butylcarbodiimide (3). 
NMR tube reaction of 1,2-bis(4-(trifluoromethyl)phenyl)diazene and tert-butylisocyanide to form 1-tert-butyl-3-(4-(trifluoromethyl)phenyl)carbodiimide (2f) and 1,3-di-tertbutylcarbodiimide (3) (Table 2 Entry 6):

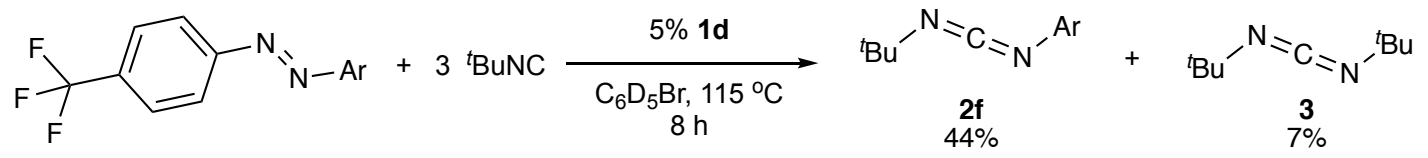

For Table 2, Entry 6, a separate stock solution was used in the NMR tube reaction of 1tert-butyl-3-(4-(trifluoromethyl)phenyl)carbodiimide (2f). A stock solution of $\mathrm{C}_{6} \mathrm{D}_{5} \mathrm{Br}$ containing $0.0165 \mathrm{M}$ [py $\left.2 \mathrm{TiBr}_{2}\left(\mathrm{~N}^{t} \mathrm{Bu}\right)\right]_{2}(7.2 \mathrm{mg}, 0.0824 \mathrm{mmol}, 10 \mathrm{~mol} \%$ in Ti), $0.330 \mathrm{M}$ 1,2-bis(4-(trifluoromethyl)phenyl)diazene $(52.5 \mathrm{mg}, 0.165 \mathrm{mmol}), 0.986 \mathrm{M}$ tert-butyl

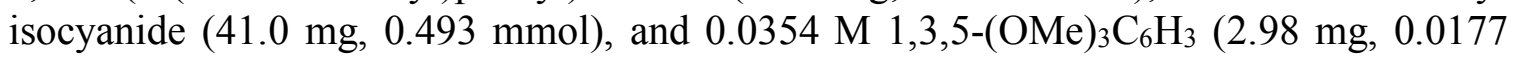
mmol) as an internal standard was prepared. In an $\mathrm{N}_{2}$ glovebox, $0.5 \mathrm{~mL}$ of the stock solution was added to an NMR tube. The NMR tube was sealed, then wrapped with electric tape and parafilm, and an initial $\mathrm{t}=0{ }^{1} \mathrm{H}$ NMR spectrum was taken. The reaction was then heated in an oil bath for $8 \mathrm{~h}$ at $115^{\circ} \mathrm{C}$. After $8 \mathrm{~h}$, a final ${ }^{1} \mathrm{H}$ NMR spectrum was taken. Yields were determined by referencing to the internal standard, 1,3,5-(OMe ${ }_{3} \mathrm{C}_{6} \mathrm{H}_{3}$.

1-tert-butyl-3-(4-(trifluoromethyl)phenyl))carbodiimide:

${ }^{1} \mathrm{H}$ NMR (400 MHz, $\mathrm{C}_{6} \mathrm{D}_{5} \mathrm{Br}, 25^{\circ} \mathrm{C}, \delta$, ppm): 7.38 (d, 2H, $\left.J=8.1 \mathrm{~Hz}, \operatorname{Ar}-H\right), 7.07$ (d, 2H, $J=8.0 \mathrm{~Hz}, \mathrm{Ar}-\mathrm{H}), 1.28\left(\mathrm{~s}, 9 \mathrm{H},-\mathrm{C}\left(\mathrm{CH}_{3}\right)_{3}\right)$.

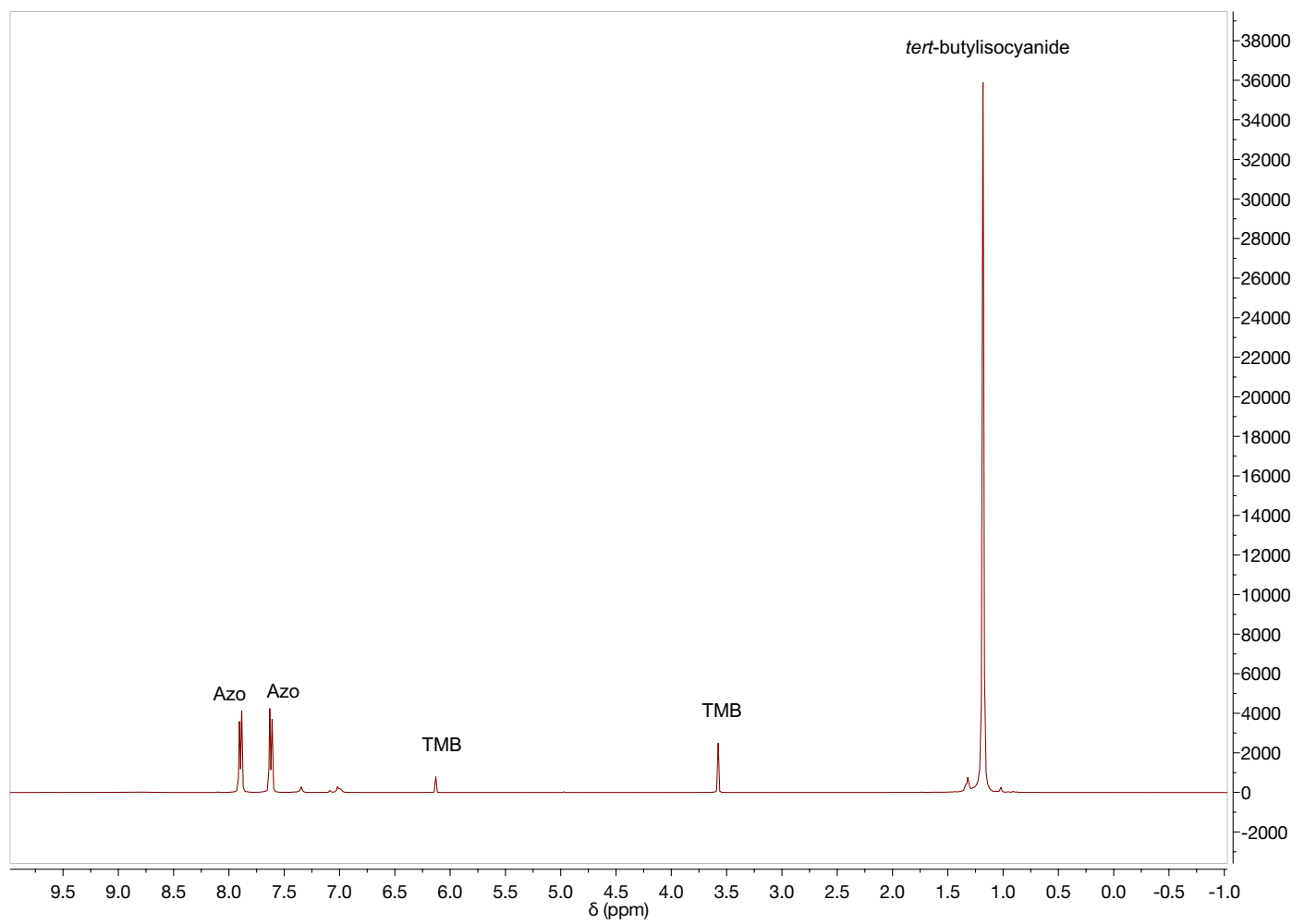


Figure S27. ${ }^{1} \mathrm{H}$ NMR spectrum of the reaction of 1,2-bis(4(trifluoromethyl)phenyl)diazene and tert-butylisocyanide at $\mathrm{t}=0$ in $\mathrm{C}_{6} \mathrm{D}_{5} \mathrm{Br}$.

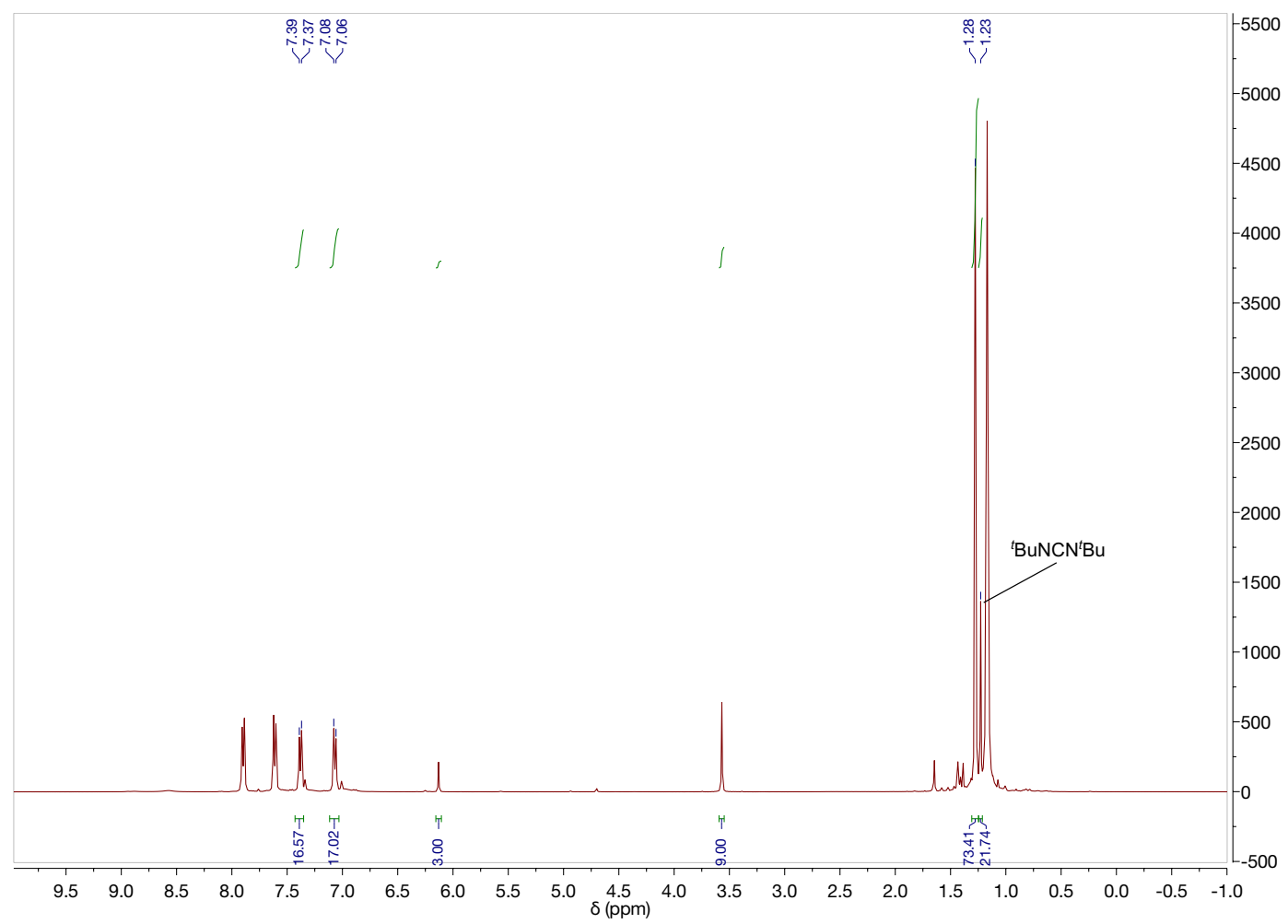

Figure S28. ${ }^{1} \mathrm{H} \quad \mathrm{NMR}$ spectrum of the reaction of 1,2-bis(4(trifluoromethyl)phenyl)diazene and tert-butylisocyanide at $\mathrm{t}=8 \mathrm{~h}$ in $\mathrm{C}_{6} \mathrm{D}_{5} \mathrm{Br}$ showing the formation of 1-tert-butyl-3-(4-(trifluoromethyl)phenyl)carbodiimide (2f) and 1,3-di-tertbutylcarbodiimide (3). 


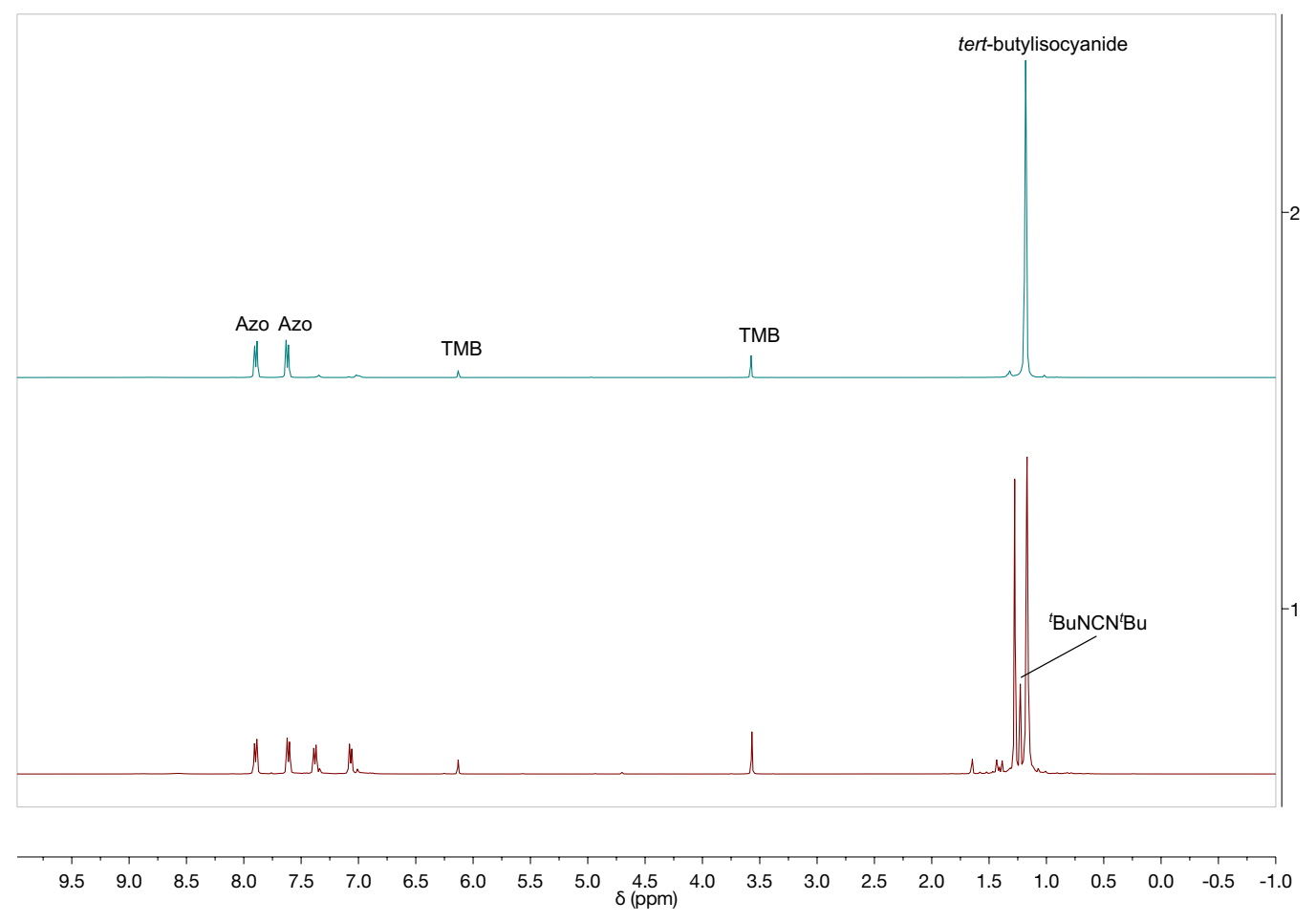

Figure S29. Stacked ${ }^{1} \mathrm{H}$ NMR spectrum of the reaction of 1,2-bis(4(trifluoromethyl)phenyl)diazene and tert-butylisocyanide at $\mathrm{t}=0$ (top) and $\mathrm{t}=8 \mathrm{~h}$ (bottom) in $\mathrm{C}_{6} \mathrm{D}_{5} \mathrm{Br}$ showing the formation of 1-tert-butyl-3-(4(trifluoromethyl)phenyl)carbodiimide (2f) and 1,3-di-tert-butylcarbodiimide (3). 
NMR tube reaction of 1,2-di-o-tolyldiazene and tert-butylisocyanide to form 1-tert-butyl3-(o-tolyl)carbodiimide (2g) and 1,3-di-tert-butylcarbodiimide (3) (Table 2 Entry 7):

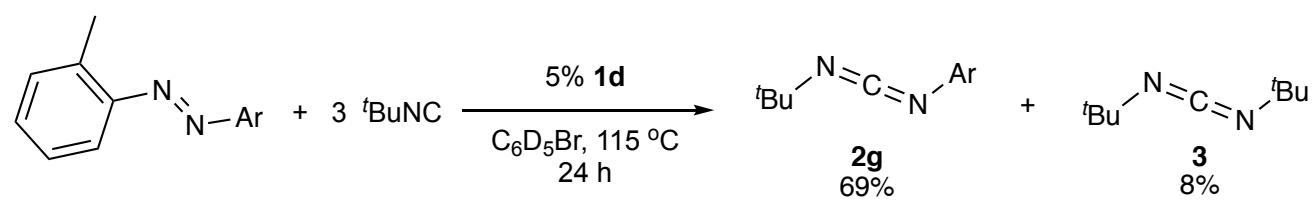

1-tert-butyl-3-(o-tolyl)carbodiimide:

${ }^{1} \mathrm{H}$ NMR $\left(500 \mathrm{MHz}, \mathrm{C}_{6} \mathrm{D}_{5} \mathrm{Br}, 27^{\circ} \mathrm{C}, \delta\right.$, ppm): $7.17(\mathrm{~d}, 1 \mathrm{H}, J=7.5 \mathrm{~Hz}, \mathrm{Ar}-H)$, 7.07-7.02 $(\mathrm{m}, 2 \mathrm{H}, \mathrm{Ar}-H), 6.94$ (t, $1 \mathrm{H}, J=7.4 \mathrm{~Hz}, \mathrm{Ar}-H), 2.28\left(\mathrm{~s}, 3 \mathrm{H}, \mathrm{Ar}-\mathrm{CH}_{3}\right), 1.24$ (s, $\left.9 \mathrm{H},-\mathrm{C}\left(\mathrm{CH}_{3}\right)_{3}\right)$.

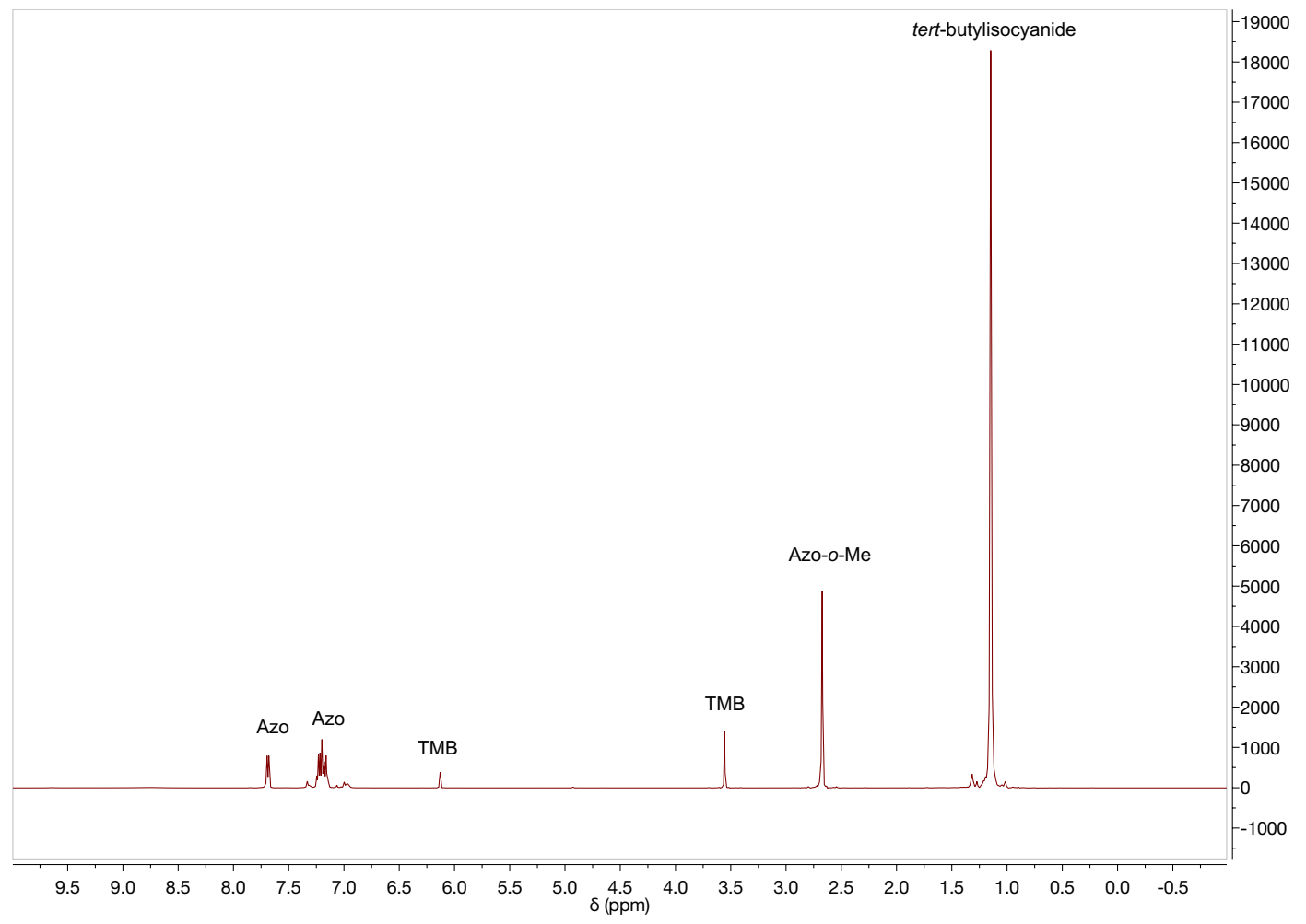

Figure S30. ${ }^{1} \mathrm{H}$ NMR spectrum of the reaction of 1,2-di-o-tolyldiazene and tertbutylisocyanide at $\mathrm{t}=0$ in $\mathrm{C}_{6} \mathrm{D}_{5} \mathrm{Br}$. 


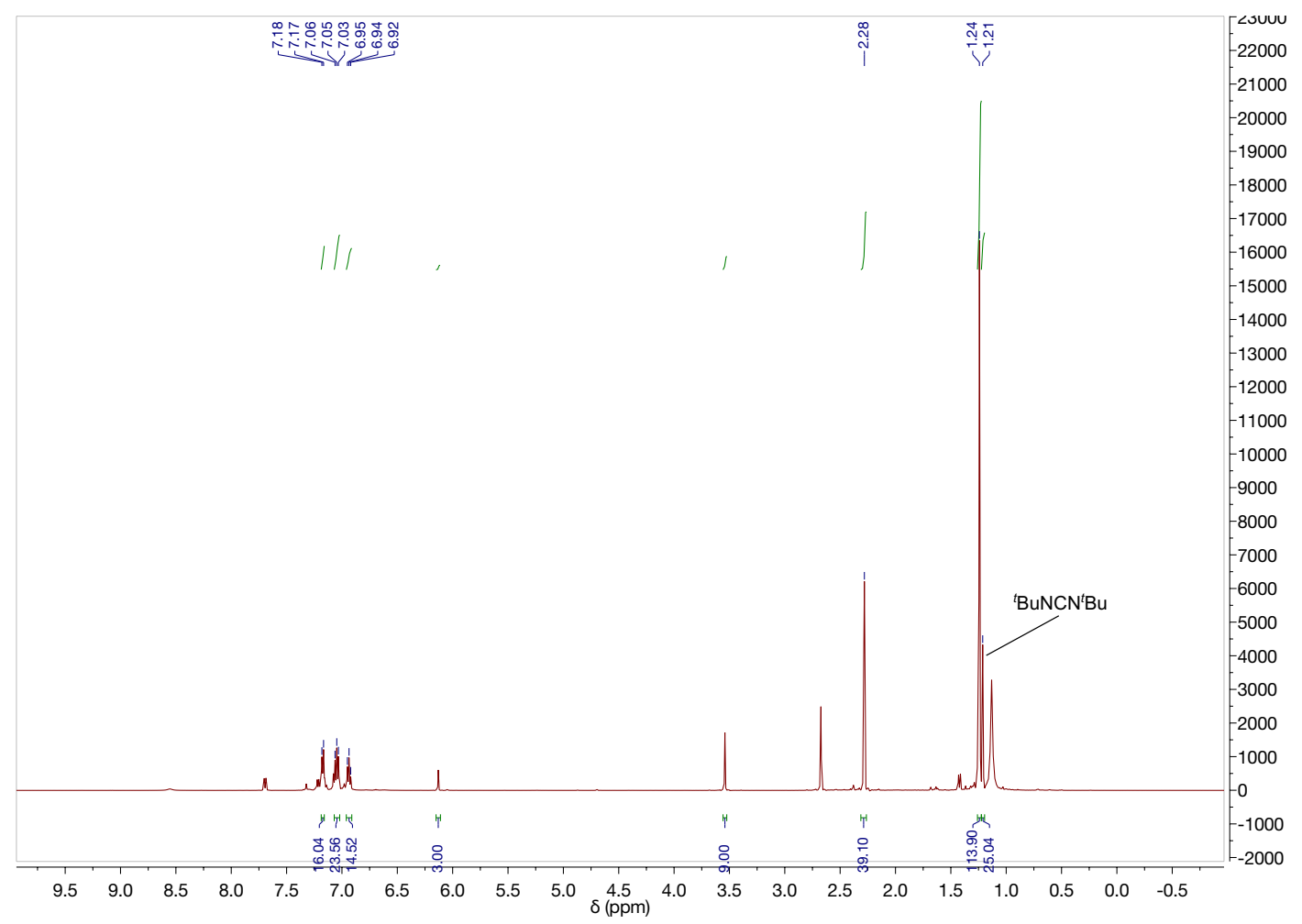

Figure S31. ${ }^{1} \mathrm{H}$ NMR spectrum of the reaction of 1,2-di-o-tolyldiazene and tertbutylisocyanide at $\mathrm{t}=24 \mathrm{~h}$ in $\mathrm{C}_{6} \mathrm{D}_{5} \mathrm{Br}$ showing the formation of 1-tert-butyl-3-(otolyl)carbodiimide (2g) and 1,3-di-tert-butylcarbodiimide (3). 


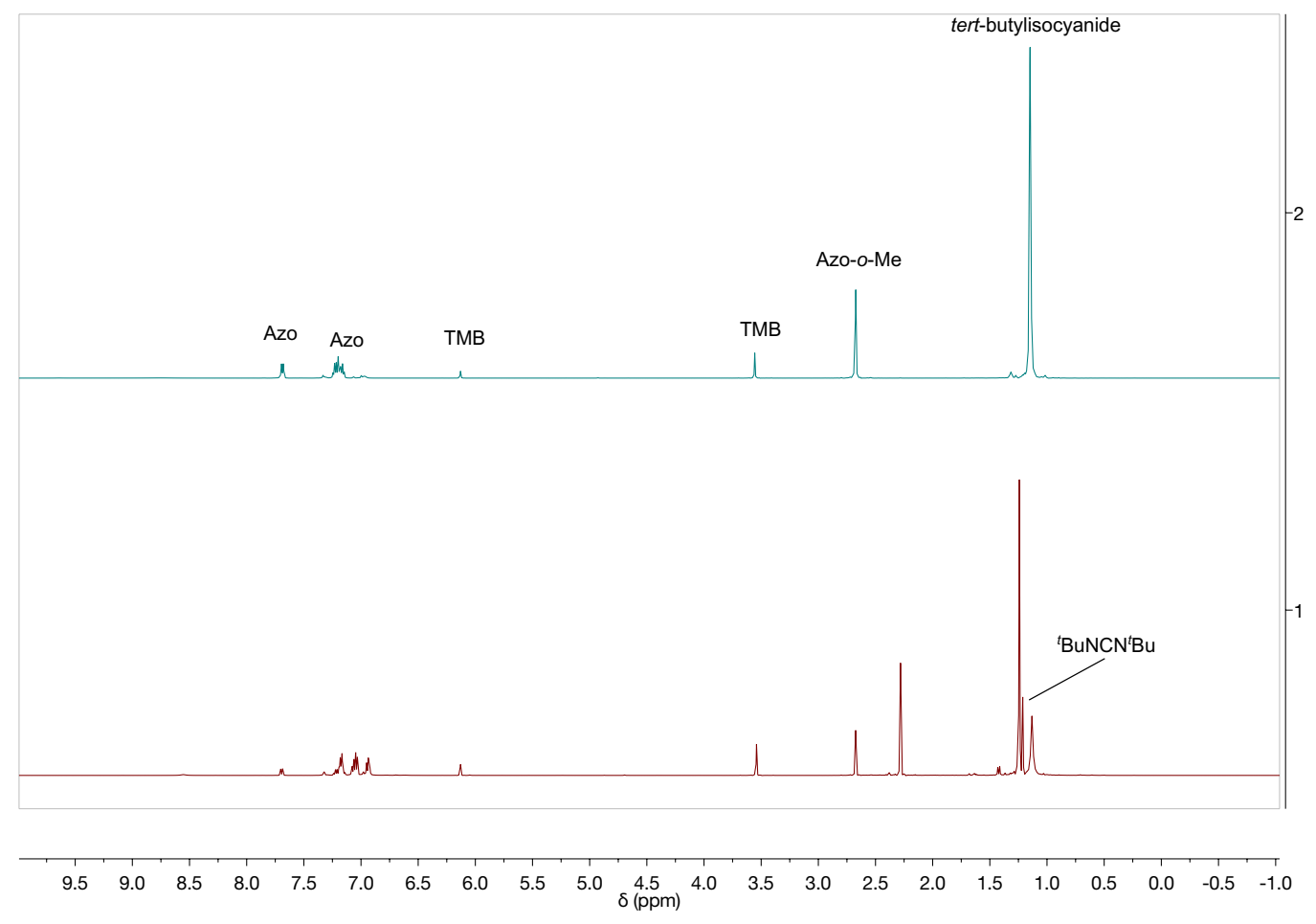

Figure S32. Stacked ${ }^{1} \mathrm{H}$ NMR spectrum of the reaction of 1,2-di-o-tolyldiazene and tertbutylisocyanide at $\mathrm{t}=0$ (top) and $\mathrm{t}=24 \mathrm{~h}$ (bottom) in $\mathrm{C}_{6} \mathrm{D}_{5} \mathrm{Br}$ showing the formation of 1 tert-butyl-3-(o-tolyl)carbodiimide (2g) and 1,3-di-tert-butylcarbodiimide (3). 
NMR tube reaction of 1,2-bis(2-ethylphenyl)diazene and tert-butylisocyanide to form 1tert-butyl-3-(2-ethylphenyl)carbodiimide (2h) and 1,3-di-tert-butylcarbodiimide (3) (Table 2 Entry 8):

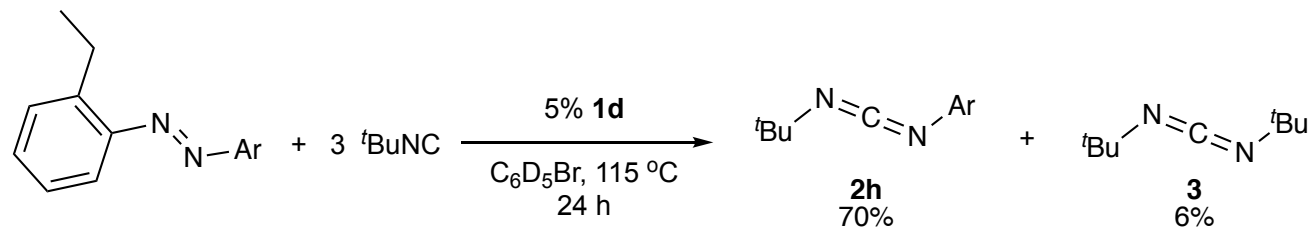

1-tert-butyl-3-(2-ethylphenyl)carbodiimide:

${ }^{1} \mathrm{H}$ NMR $\left(500 \mathrm{MHz}, \mathrm{C}_{6} \mathrm{D}_{5} \mathrm{Br}, 27^{\circ} \mathrm{C}, \delta\right.$, ppm): 7.19 (d, $\left.1 \mathrm{H}, J=7.7 \mathrm{~Hz}, \mathrm{Ar}-H\right), 7.08-7.06$ (m, 2H, Ar- $H$ ), 6.98 (t, $1 \mathrm{H}, J=7.3 \mathrm{~Hz}, \mathrm{Ar}-H), 2.70$ (q, $\left.2 \mathrm{H}, J=7.5 \mathrm{~Hz}, \operatorname{Ar}-\mathrm{CH}_{2}\right), 1.25$ (s, $\left.9 \mathrm{H},-\mathrm{C}\left(\mathrm{CH}_{3}\right)_{3}\right), 1.17\left(\mathrm{t}, 3 \mathrm{H}, J=7.5 \mathrm{~Hz},-\mathrm{CH}_{2} \mathrm{CH}_{3}\right)$.

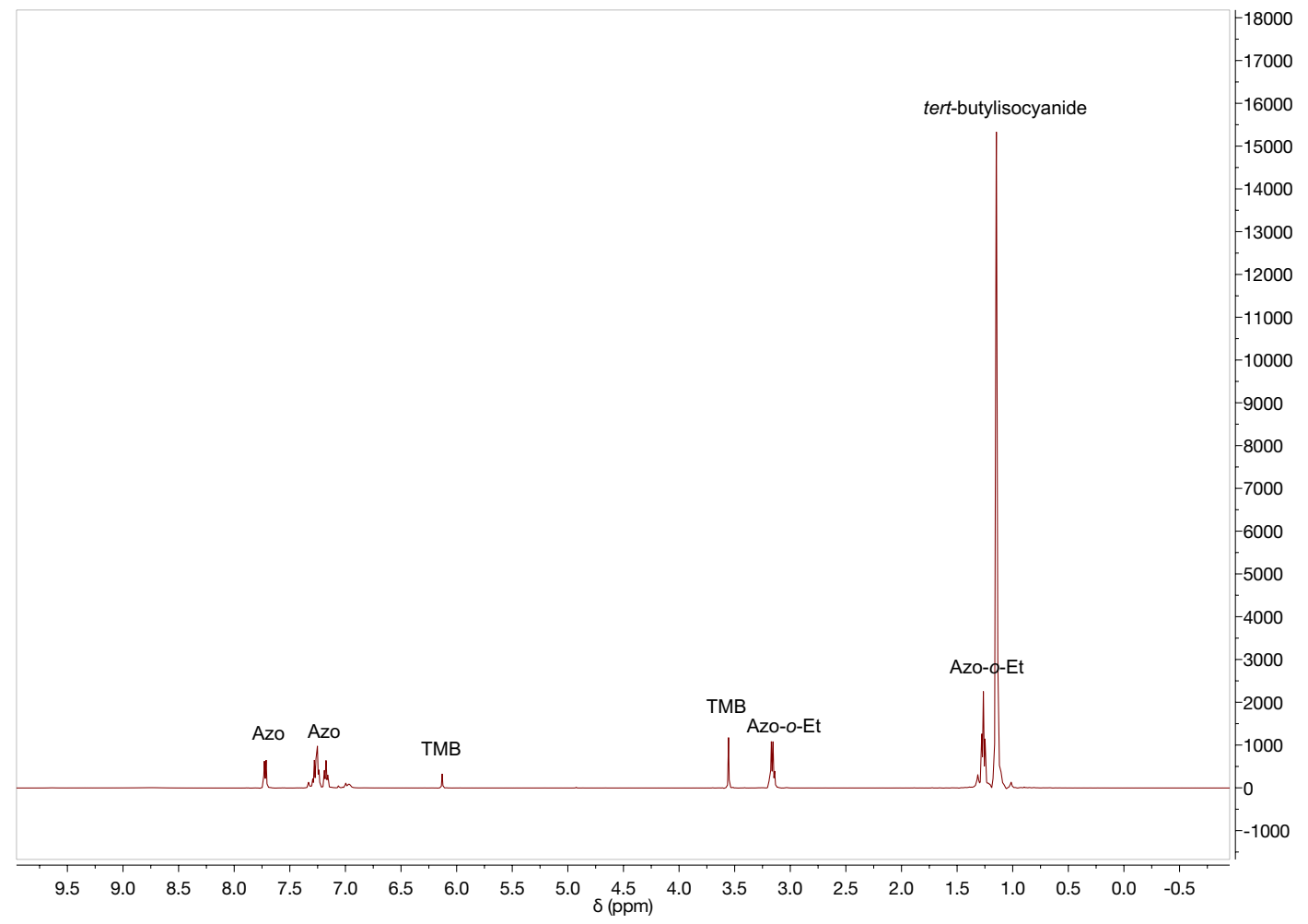

Figure S33. ${ }^{1} \mathrm{H}$ NMR spectrum of the reaction of 1,2-bis(2-ethylphenyl)diazene and tertbutylisocyanide at $\mathrm{t}=0$ in $\mathrm{C}_{6} \mathrm{D}_{5} \mathrm{Br}$. 


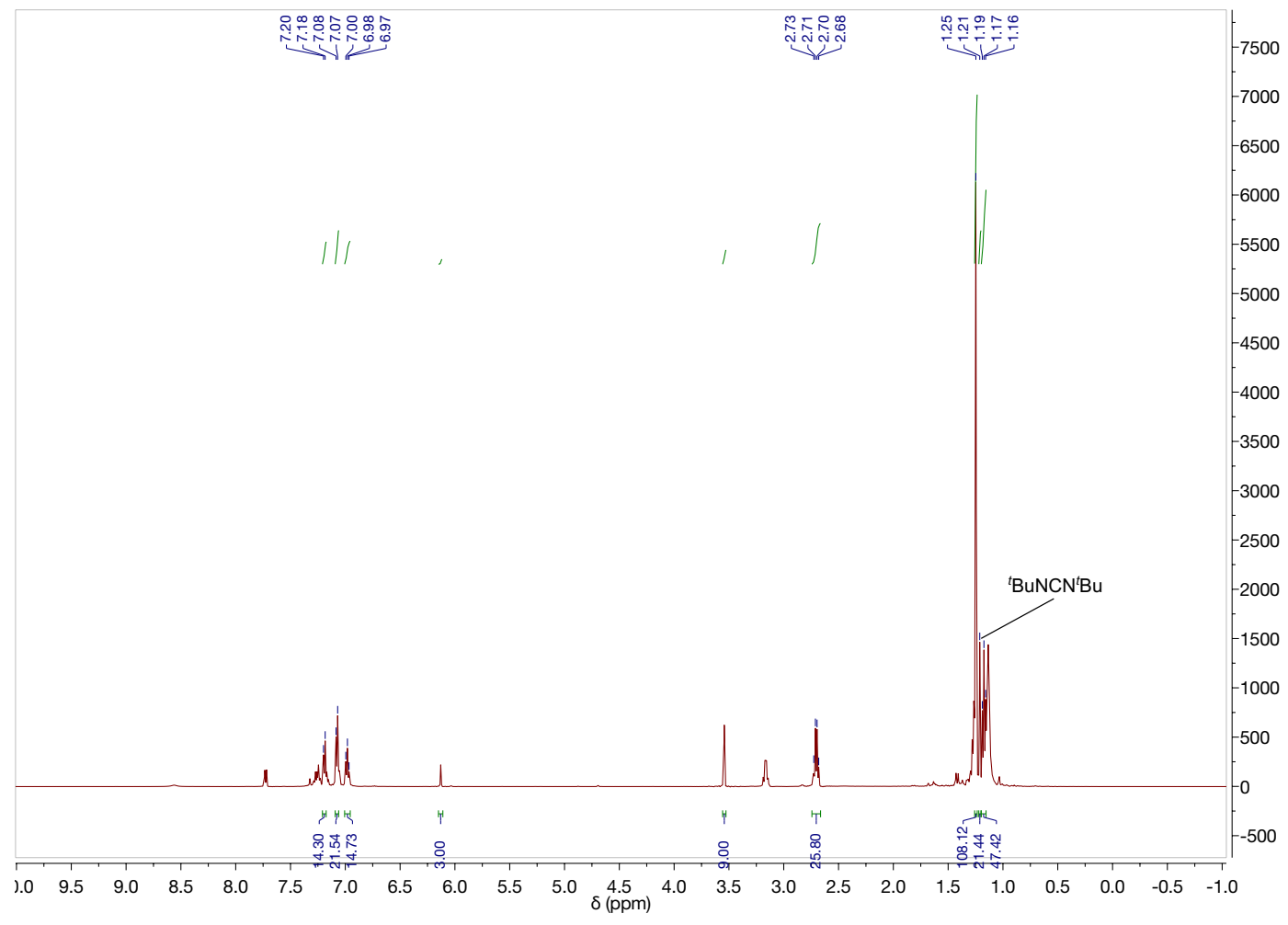

Figure S34. ${ }^{1} \mathrm{H}$ NMR spectrum of the reaction of 1,2-bis(2-ethylphenyl)diazene and tertbutylisocyanide at $\mathrm{t}=24 \mathrm{~h}$ in $\mathrm{C}_{6} \mathrm{D}_{5} \mathrm{Br}$ showing the formation of 1-tert-butyl-3-(2ethylphenyl)carbodiimide (2h) and 1,3-di-tert-butylcarbodiimide (3). 


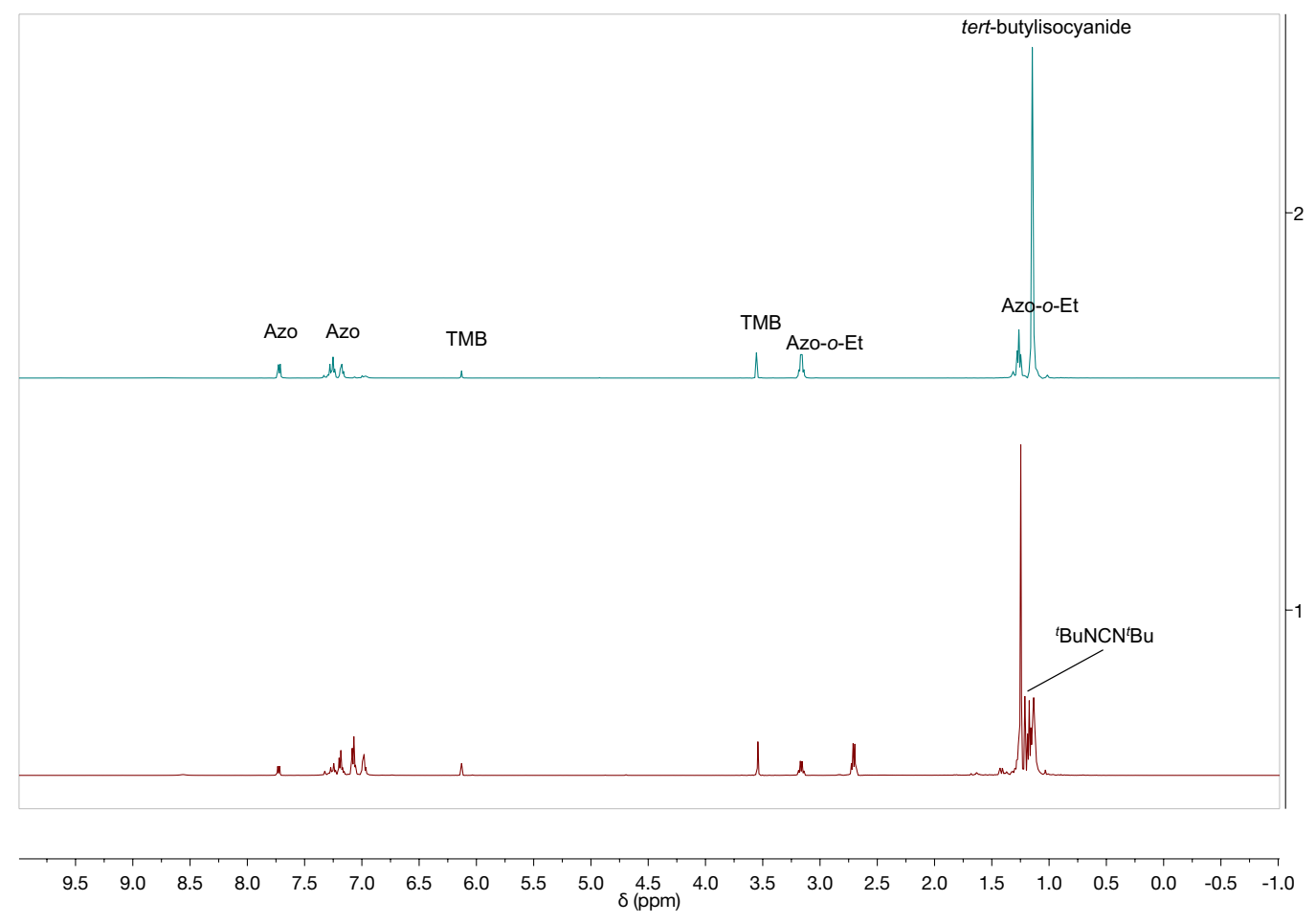

Figure S35. Stacked ${ }^{1} \mathrm{H}$ NMR spectrum of the reaction of 1,2-bis(2-ethylphenyl)diazene and tert-butylisocyanide at $\mathrm{t}=0$ (top) and $\mathrm{t}=24 \mathrm{~h}$ (bottom) in $\mathrm{C}_{6} \mathrm{D}_{5} \mathrm{Br}$ showing the formation of 1-tert-butyl-3-(2-ethylphenyl)carbodiimide (2h) and 1,3-di-tertbutylcarbodiimide (3). 
NMR tube reaction of 1,2-bis(2-isopropylphenyl)diazene and tert-butylisocyanide to form 1-tert-butyl-3-(2-isopropylphenyl)carbodiimide (2i) and 1,3-di-tert-butylcarbodiimide (3) (Table 2 Entry 9):

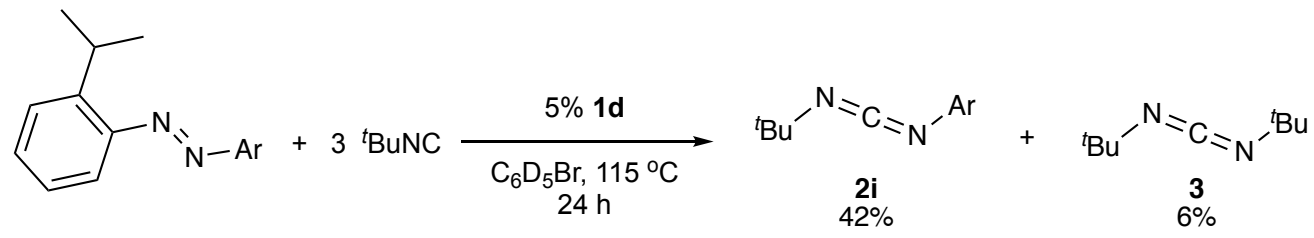

1-tert-butyl-3-(2-isopropylphenyl)carbodiimide:

${ }^{1} \mathrm{H}$ NMR $\left(500 \mathrm{MHz}, \mathrm{C}_{6} \mathrm{D}_{5} \mathrm{Br}, 2{ }^{\circ} \mathrm{C}, \delta\right.$, ppm): 7.23-7.14 (m, 2H, Ar-H, overlaps with residual diazene), 7.08-7.01 (m, 2H, Ar- $H$ ), 3.49 (septet, $1 \mathrm{H}, J=6.9 \mathrm{~Hz}, \mathrm{Ar}-\mathrm{CH}), 1.25$ (s, $\left.9 \mathrm{H},-\mathrm{C}\left(\mathrm{CH}_{3}\right)_{3}\right), 1.19\left(\mathrm{~d}, 6 \mathrm{H}, \mathrm{J}=6.9 \mathrm{~Hz},-\mathrm{CH}\left(\mathrm{CH}_{3}\right)_{2}\right)$.

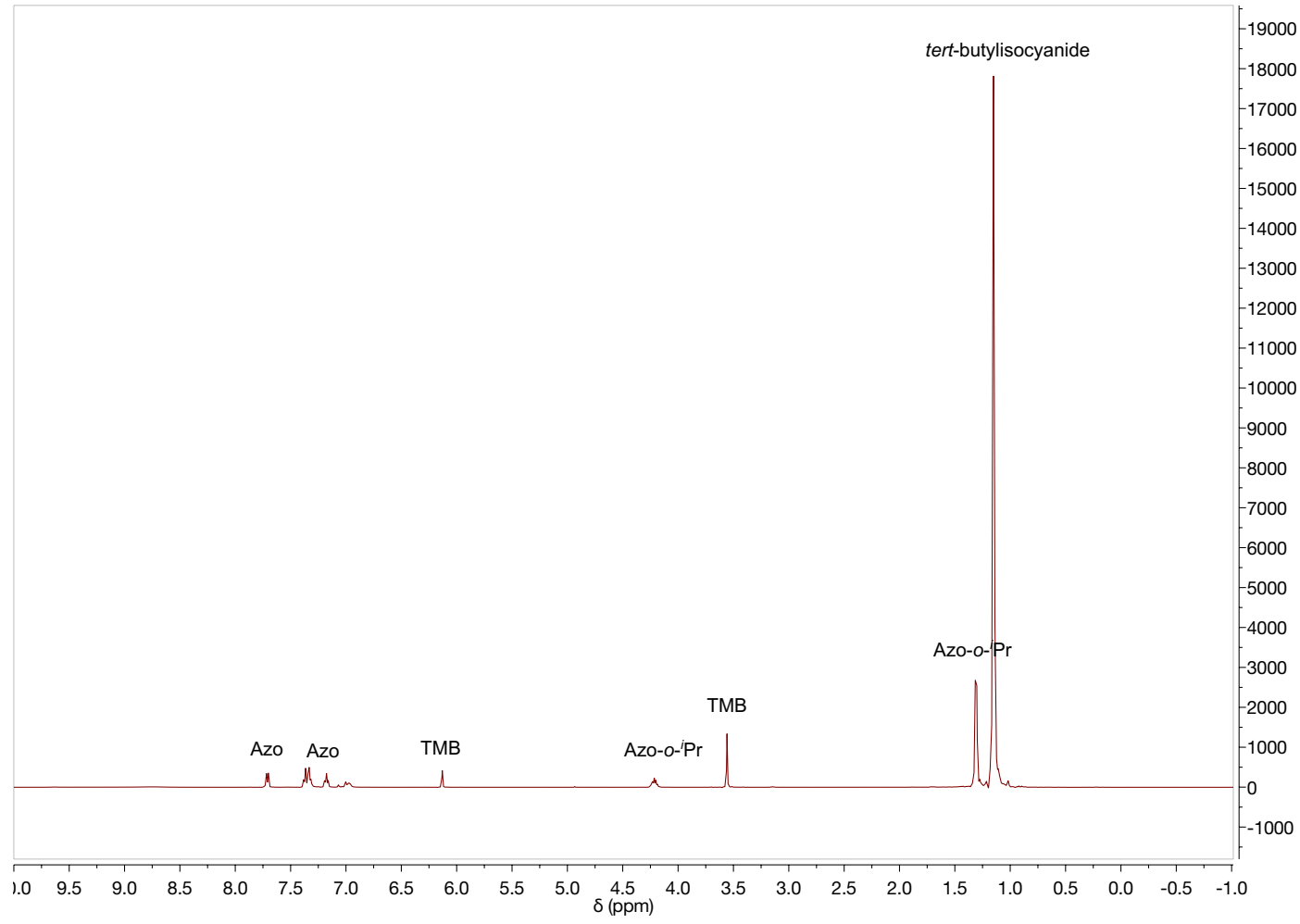

Figure S36. ${ }^{1} \mathrm{H}$ NMR spectrum of the reaction of 1,2-bis(2-isopropylphenyl)diazene and tert-butylisocyanide at $\mathrm{t}=0$ in $\mathrm{C}_{6} \mathrm{D}_{5} \mathrm{Br}$. 


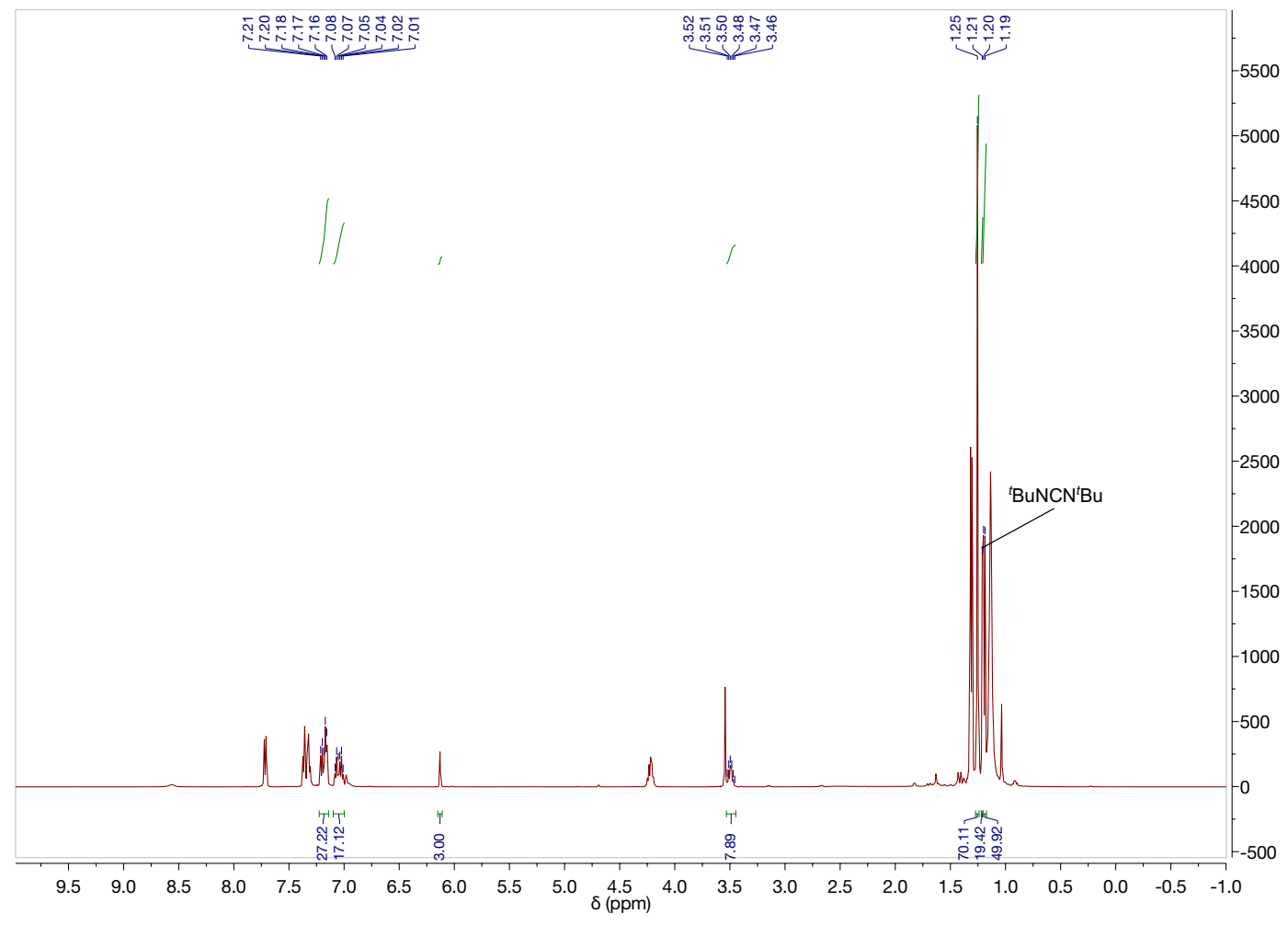

Figure S37. ${ }^{1} \mathrm{H}$ NMR spectrum of the reaction of 1,2-bis(2-isopropylphenyl)diazene and tert-butylisocyanide at $\mathrm{t}=24 \mathrm{~h}$ in $\mathrm{C}_{6} \mathrm{D}_{5} \mathrm{Br}$ showing the formation of 1-tert-butyl-3-(2isopropylphenyl)carbodiimide (2i) and 1,3-di-tert-butylcarbodiimide (3). 


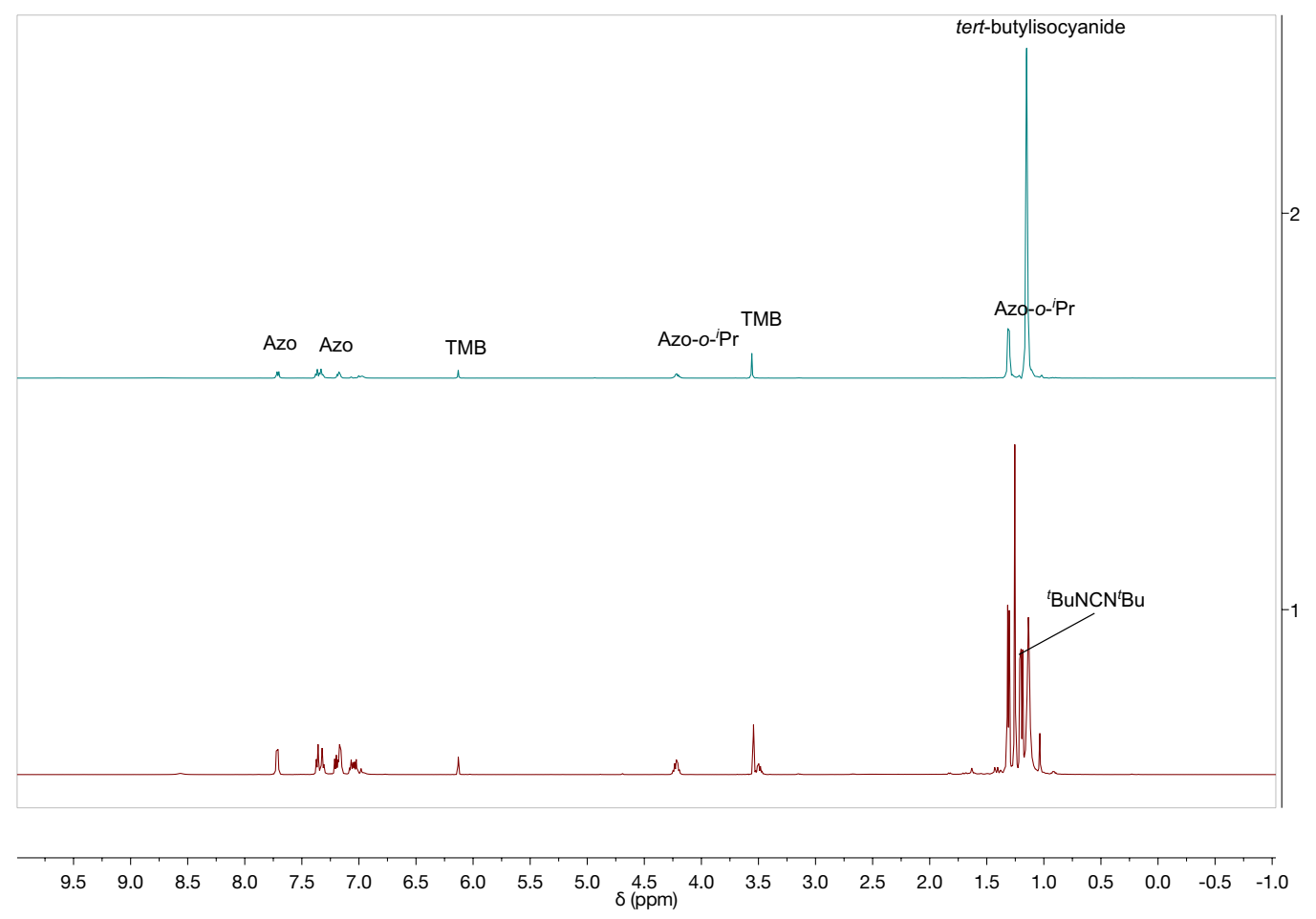

Figure S38. Stacked ${ }^{1} \mathrm{H}$ NMR spectrum of the reaction of 1,2-bis(2isopropylphenyl)diazene and tert-butylisocyanide at $\mathrm{t}=0$ (top) and $\mathrm{t}=24 \mathrm{~h}$ (bottom) in $\mathrm{C}_{6} \mathrm{D}_{5} \mathrm{Br}$ showing the formation of 1-tert-butyl-3-(2-isopropylphenyl)carbodiimide (2i) and 1,3-di-tert-butylcarbodiimide (3). 


\section{Isolation of new carbodiimides from Table 2:}

All new carbodiimides from the diazene scope (Table 2, entries 5 (2e), 8 (2h), and $9(\mathbf{2 i})$ ), were synthesized following the general procedure: in an $\mathrm{N}_{2}$-filled glovebox, an NMR tube was loaded with substituted diazene $\left(0.17 \mathrm{mmol}, 1\right.$ equiv.), $\left[\mathrm{py}_{2} \mathrm{TiBr}_{2}\left(\mathrm{~N}^{t} \mathrm{Bu}\right)\right]_{2}(7.2 \mathrm{mg}$, $0.0083 \mathrm{mmol}, 0.05$ equiv., $10 \mathrm{~mol} \%$ in Ti), tert-butyl isocyanide (41 mg, $0.49 \mathrm{mmol}, 3$ equiv.), and $\mathrm{PhCF}_{3}$ (approximately $0.5 \mathrm{~mL}$ ). The tube was capped and removed from the glovebox, then wrapped with electric tape and parafilm, and heated in an oil bath at $115^{\circ} \mathrm{C}$ for 24 hours. The reaction mixture was then transferred to a round bottom flask using $\mathrm{CH}_{2} \mathrm{Cl}_{2}$ to aid in transfer, and the volatiles were removed on a rotary evaporator under reduced pressure. The resulting oil was purified via column chromatography (silica) to afford pure 1-tert-butyl-3-aryl carbodiimide.

Synthesis of 1-tert-butyl-3-(4-(trifluoromethoxy)phenyl))carbodiimide (2e):

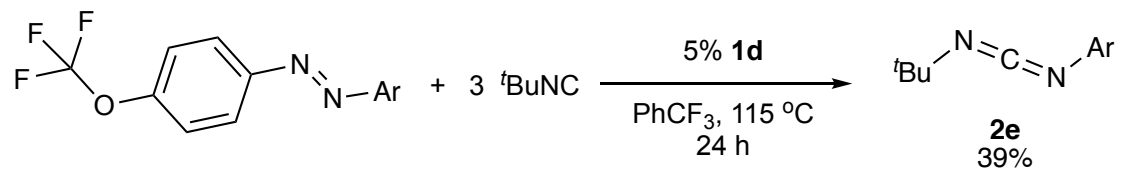

From 0.17 mmol 1,2-bis(4-(trifluoromethoxy)phenyl)diazene. Purified using an eluent of $2 \% \mathrm{EtOAc} / \mathrm{hexanes}$ (34 $\mathrm{mg}$ isolated, 39\%).

${ }^{1} \mathrm{H}$ NMR $\left(400 \mathrm{MHz}, \mathrm{CDCl}_{3}, 25^{\circ} \mathrm{C}, \delta, \mathrm{ppm}\right): 7.13$ (d, $\left.2 \mathrm{H}, J=8.7 \mathrm{~Hz}, \mathrm{Ar}-H\right), 7.10-7.05$ (m, $2 \mathrm{H}, \mathrm{Ar}-\mathrm{H}), 1.41\left(\mathrm{~s}, 9 \mathrm{H},-\mathrm{C}\left(\mathrm{CH}_{3}\right)_{3}\right)$.

${ }^{13} \mathrm{C}$ NMR (101 MHz, $\left.\mathrm{CDCl}_{3}, 25{ }^{\circ} \mathrm{C}, \delta, \mathrm{ppm}\right): 145.9,140.1,135.6,124.4,122.3,120.6$ (q, $\left.J_{\mathrm{C}-\mathrm{F}}=257.6 \mathrm{~Hz}\right), 57.9,31.7$.

${ }^{19} \mathrm{~F}$ NMR $\left(376 \mathrm{MHz}, \mathrm{CDCl}_{3}, 25^{\circ} \mathrm{C}, \delta, \mathrm{ppm}\right):-57.0\left(\mathrm{~s},-\mathrm{OC} F_{3}\right)$.

GC-HRMS (m/z): calcd. for $\mathrm{C}_{12} \mathrm{H}_{13} \mathrm{~N}_{2} \mathrm{~F}_{3} \mathrm{O}, 258.0980$; found, 258.0964. 


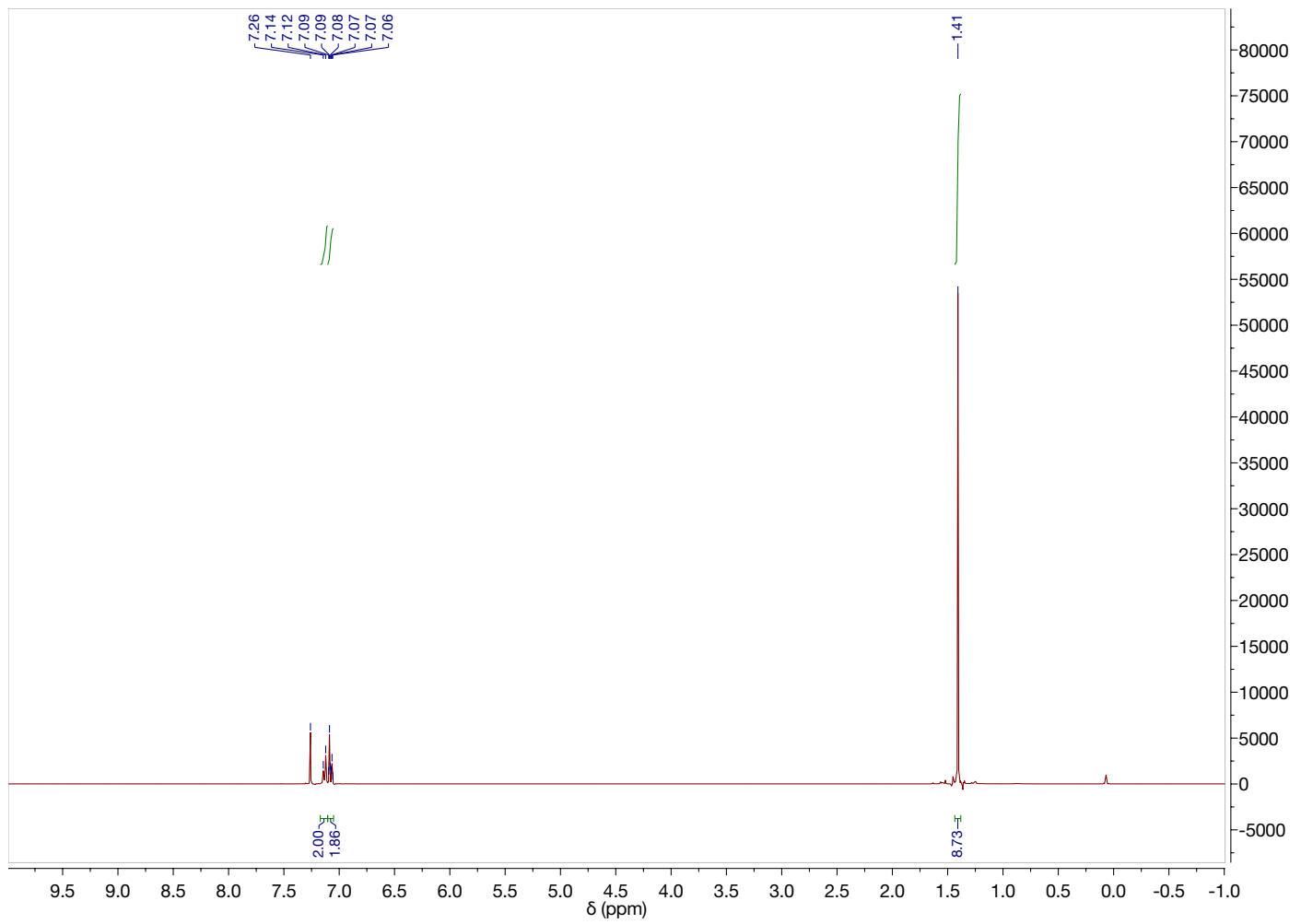

Figure S39. ${ }^{1} \mathrm{H}$ NMR of 1-tert-butyl-3-(4-(trifluoromethoxy)phenyl))carbodiimide (2e) in $\mathrm{CDCl}_{3}$. 


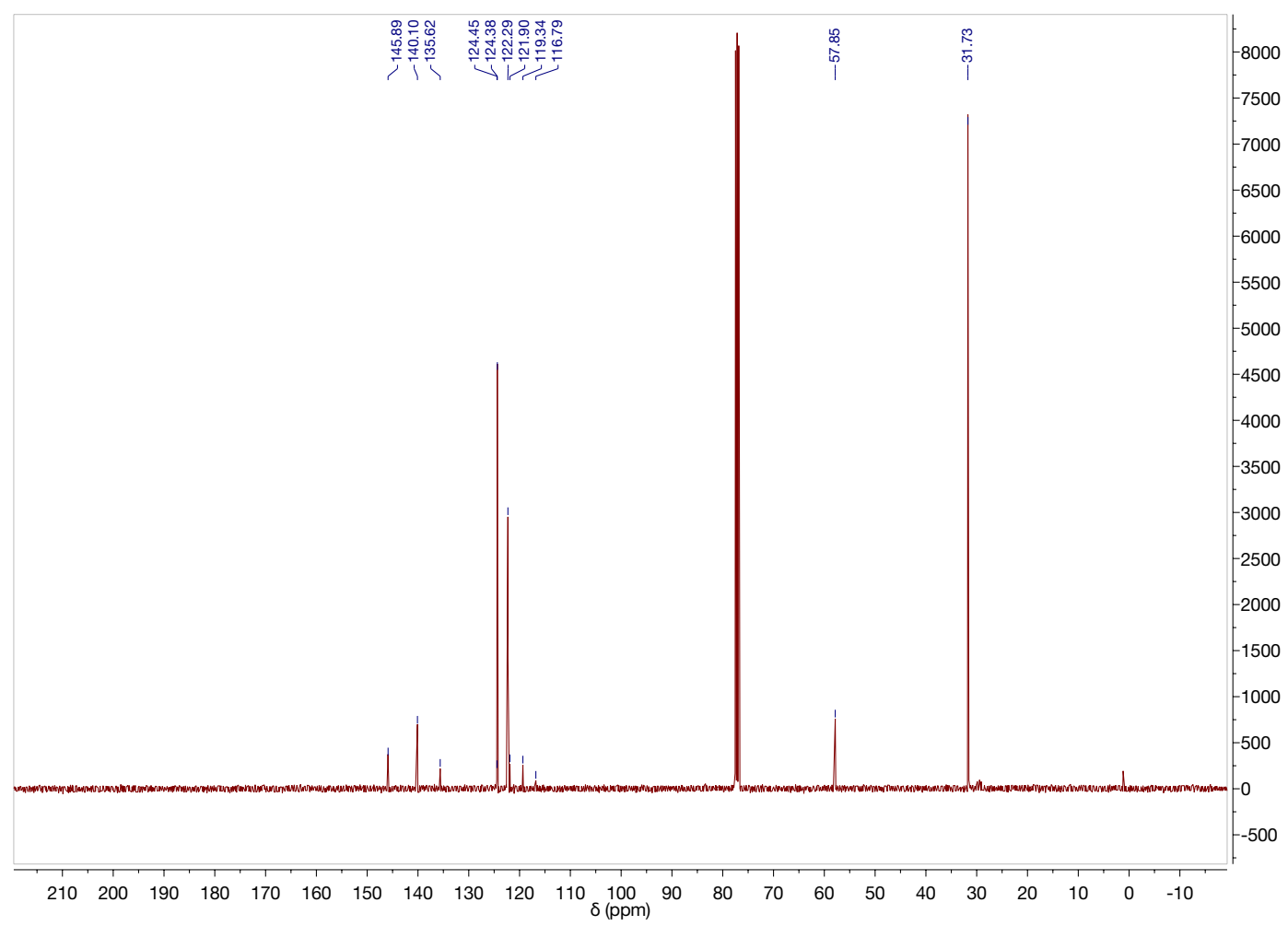

Figure S40. ${ }^{13} \mathrm{C}$ NMR of 1-tert-butyl-3-(4-(trifluoromethoxy)phenyl))carbodiimide (2e) in $\mathrm{CDCl}_{3}$. 


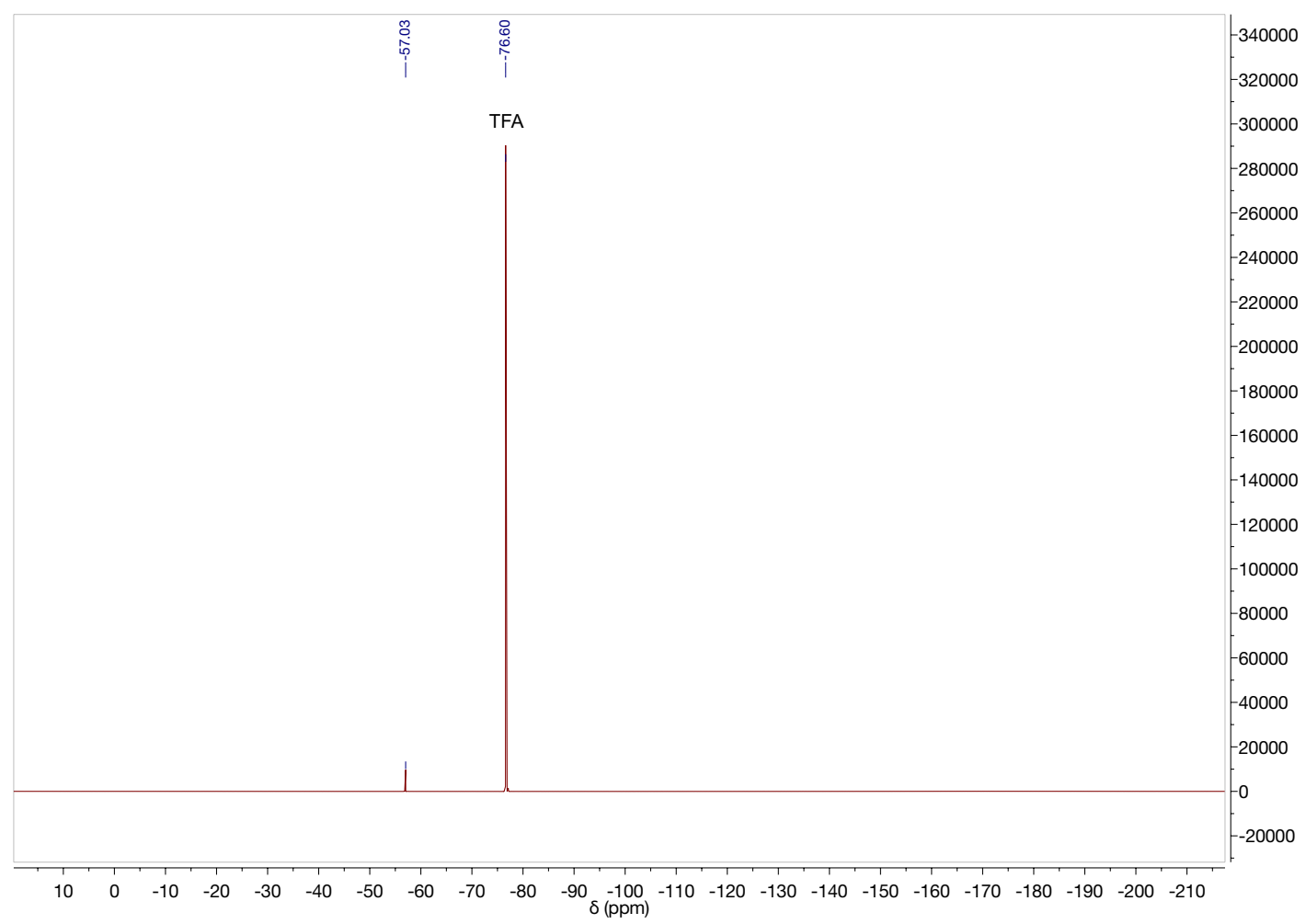

Figure S41. ${ }^{19} \mathrm{~F}$ NMR of 1-tert-butyl-3-(4-(trifluoromethoxy)phenyl))carbodiimide (2e) in $\mathrm{CDCl}_{3}$ with a trifluoroacetic acid internal reference. 
Synthesis of 1-tert-butyl-3-(2-ethylphenyl)carbodiimide (2h):

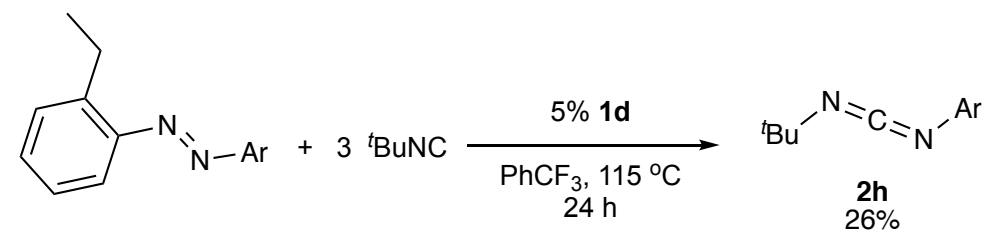

From 0.17 mmol 1,2-bis(2-ethylphenyl)diazene. Purified using an eluent of 5\% EtOAc/hexanes (17 mg isolated, 26\%).

${ }^{1} \mathrm{H}$ NMR $\left(400 \mathrm{MHz}, \mathrm{CDCl}_{3}, 25^{\circ} \mathrm{C}, \delta, \mathrm{ppm}\right): 7.19-7.10(\mathrm{~m}, 3 \mathrm{H}, \mathrm{Ar}-H), 7.08-7.01(\mathrm{~m}, 1 \mathrm{H}$, $\mathrm{Ar}-\mathrm{H}), 2.69$ (q, $\left.2 \mathrm{H}, J=7.5 \mathrm{~Hz}, \mathrm{Ar}-\mathrm{CH}_{2}\right), 1.41\left(\mathrm{~s}, 9 \mathrm{H},-\mathrm{C}\left(\mathrm{CH}_{3}\right)_{3}\right), 1.21(\mathrm{t}, 3 \mathrm{H}, J=7.5 \mathrm{~Hz}$, $\left.\mathrm{ArCH}_{2}-\mathrm{CH}_{3}\right)$.

${ }^{13} \mathrm{C}$ NMR $\left(101 \mathrm{MHz}, \mathrm{CDCl}_{3}, 25{ }^{\circ} \mathrm{C}, \delta, \mathrm{ppm}\right): 138.9,138.1,136.1,129.3,126.8,124.8$, $123.8,57.2,31.7,25.2,14.9$.

GC-HRMS (m/z): calcd. for $\mathrm{C}_{13} \mathrm{H}_{18} \mathrm{~N}_{2}, 202.1470$; found, 202.1436.

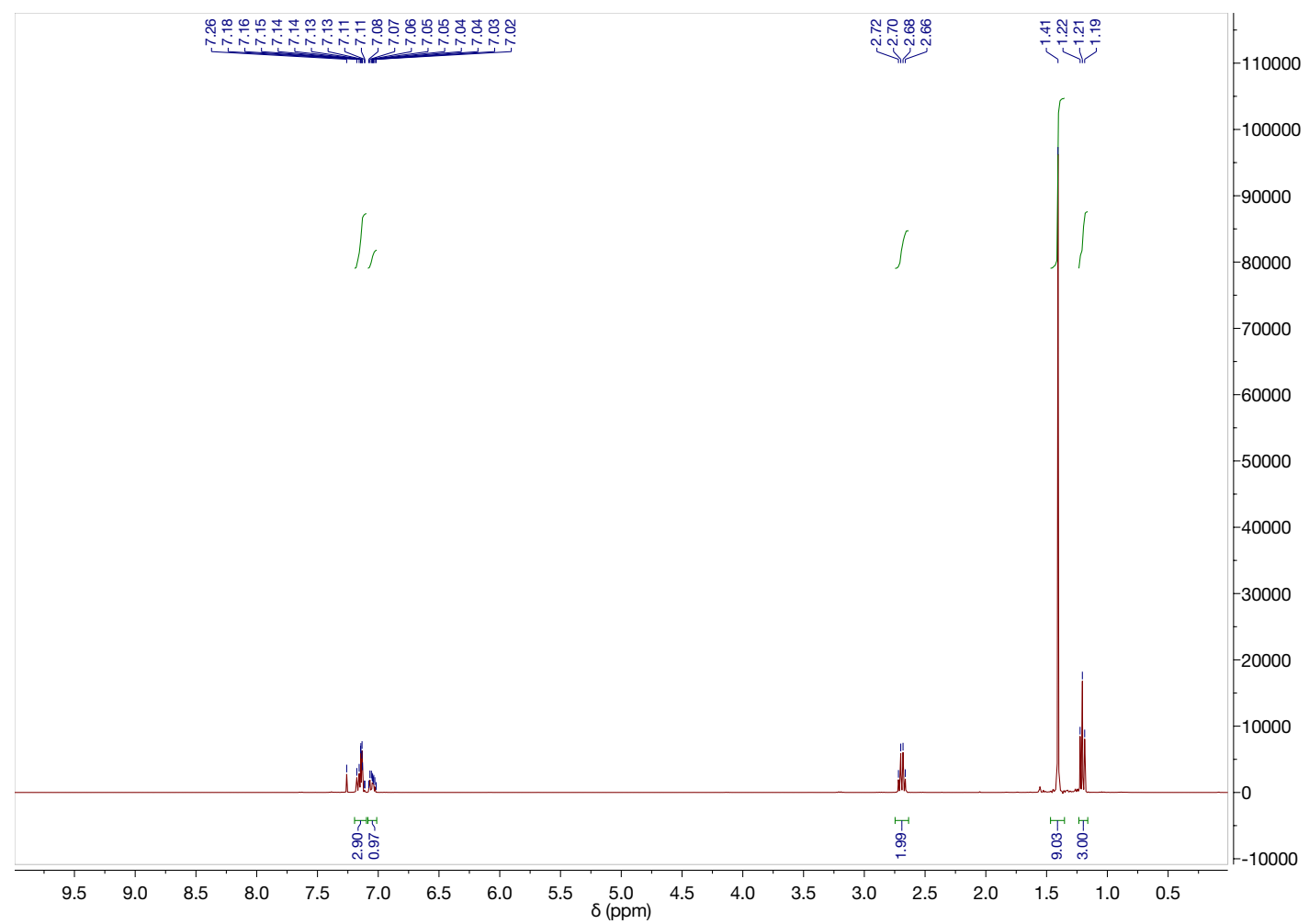

Figure S42. ${ }^{1} \mathrm{H}$ NMR of 1-tert-butyl-3-(2-ethylphenyl)carbodiimide (2h) in $\mathrm{CDCl}_{3}$. 


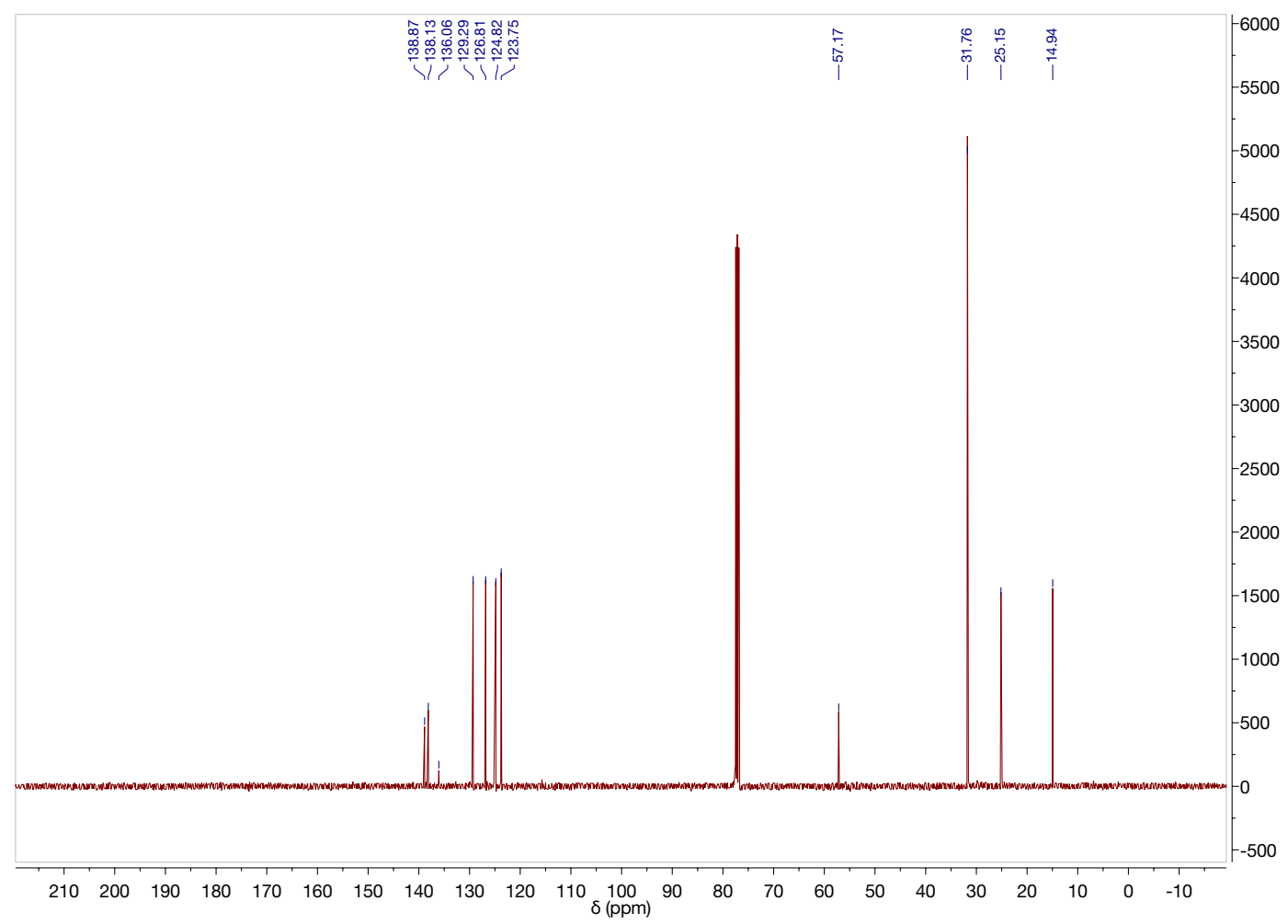

Figure S43. ${ }^{13} \mathrm{C}$ NMR of 1-tert-butyl-3-(2-ethylphenyl)carbodiimide (2h) in $\mathrm{CDCl}_{3}$. 
Synthesis of 1-tert-butyl-3-(2-isopropylphenyl)carbodiimide (2i):

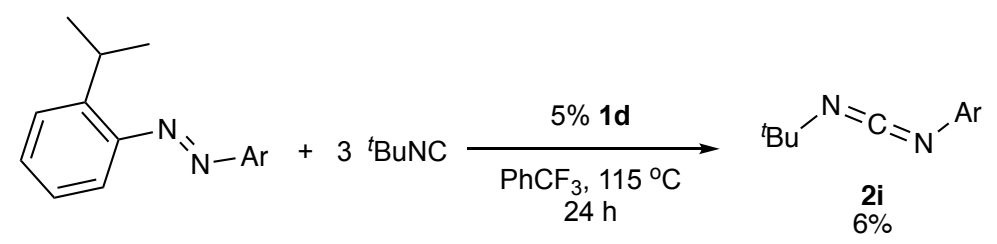

From $0.17 \mathrm{mmol}$ 1,2-bis(2-isopropylphenyl)diazene. Purified using an eluent of $2 \%$ EtOAc/hexanes (4 mg isolated, 6\%).

${ }^{1} \mathrm{H}$ NMR $\left(400 \mathrm{MHz}, \mathrm{CDCl}_{3}, 25^{\circ} \mathrm{C}, \delta, \mathrm{ppm}\right): 7.25-7.21(\mathrm{~m}, 1 \mathrm{H}, \mathrm{Ar}-\mathrm{H}), 7.16-7.06(\mathrm{~m}, 3 \mathrm{H}$, Ar- $H$ ), 3.39 (septet, $\left.1 \mathrm{H}, J=6.9 \mathrm{~Hz},-\mathrm{CH}\left(\mathrm{CH}_{3}\right)_{2}\right), 1.40\left(\mathrm{~s}, 9 \mathrm{H},-\mathrm{C}\left(\mathrm{CH}_{3}\right)_{3}\right), 1.21(\mathrm{~d}, 6 \mathrm{H}, J=$ $6.9 \mathrm{~Hz},-\mathrm{CH}\left(\mathrm{CH}_{3}\right)_{2}$.

${ }^{13} \mathrm{C}$ NMR $\left(101 \mathrm{MHz}, \mathrm{CDCl}_{3}, 25{ }^{\circ} \mathrm{C}, \delta, \mathrm{ppm}\right): 142.3,138.3,136.3,126.6,126.2,125.0$, $123.8,57.2,31.8,28.5,23.1$.

GC-HRMS (m/z): calcd. for $\mathrm{C}_{14} \mathrm{H}_{20} \mathrm{~N}_{2}, 216.1626$; found, 216.1570 .

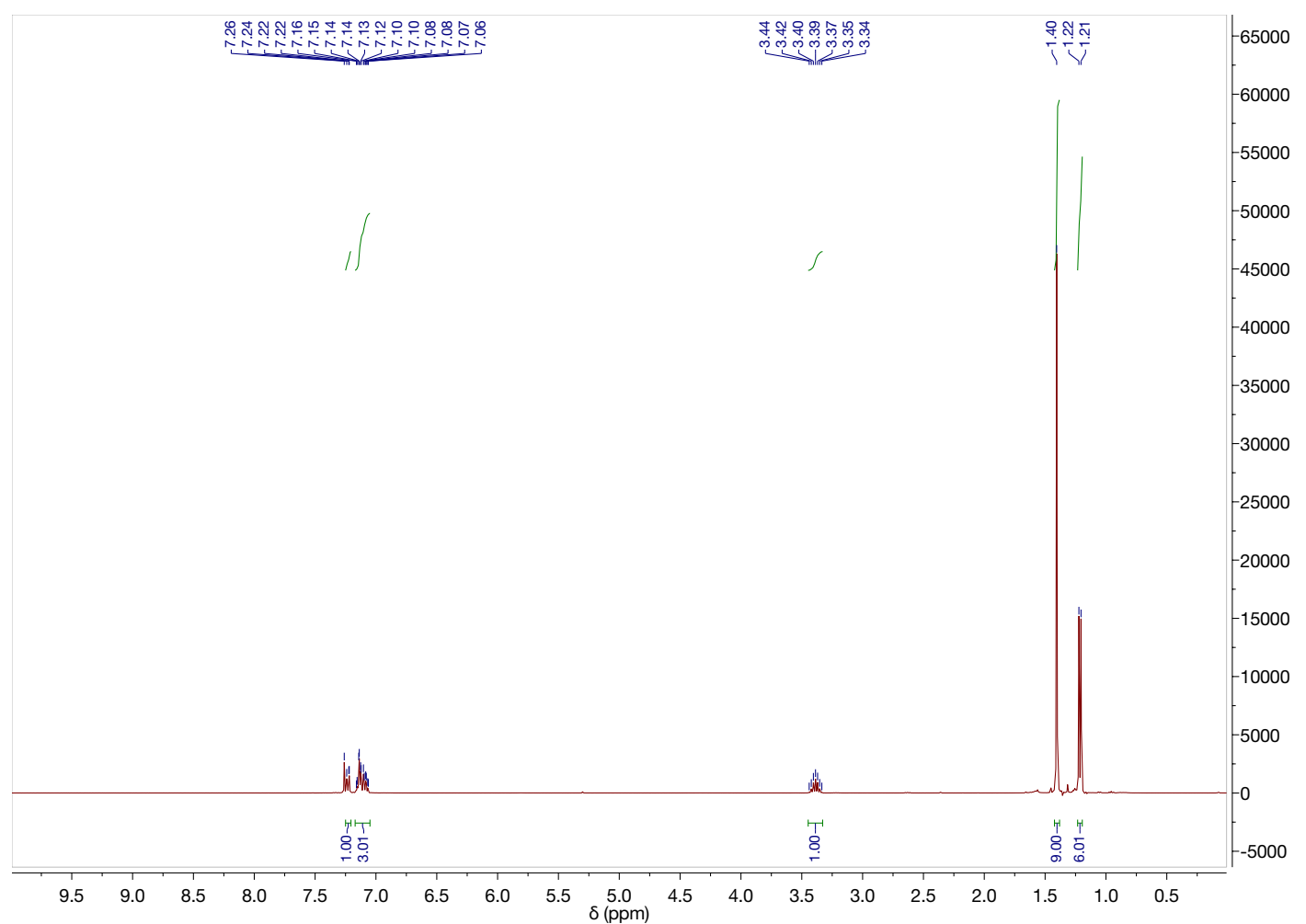

Figure S44. ${ }^{1} \mathrm{H}$ NMR of 1-tert-butyl-3-(2-isopropylphenyl)carbodiimide (2i) in $\mathrm{CDCl}_{3}$. 


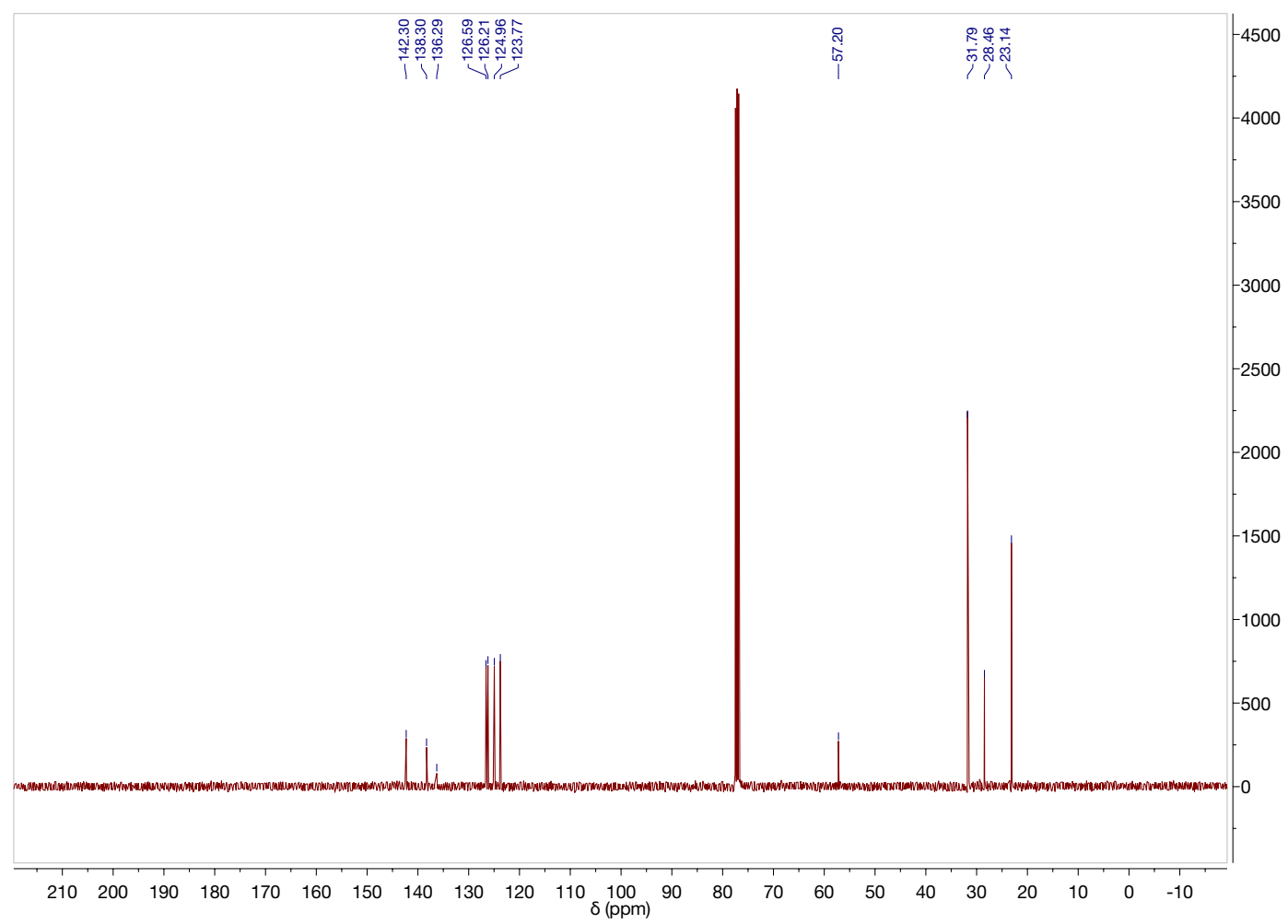

Figure S45. ${ }^{13} \mathrm{C}$ NMR of 1-tert-butyl-3-(2-isopropylphenyl)carbodiimide (2i) in $\mathrm{CDCl}_{3}$. 


\section{Isolation of known carbodiimides from Table 2:}

Known carbodiimides from the diazene scope (Table 2, entries 1-4 (2a-d) and 7 (2g)), were synthesized following the general procedure: in an $\mathrm{N}_{2}$-filled glovebox, an NMR tube was loaded with substituted diazene (0.27 mmol, 1 equiv.), [py2 $\left.\operatorname{TiBr}_{2}\left(\mathrm{~N}^{t} \mathrm{Bu}\right)\right]_{2}(12 \mathrm{mg}, 0.0014$ mmol, 0.05 equiv., $10 \mathrm{~mol} \%$ in Ti), tert-butyl isocyanide (68 $\mathrm{mg}, 0.82 \mathrm{mmol}, 3$ equiv.), $\mathrm{PhCF}_{3}$ (approximately $0.5 \mathrm{~mL}$ ), and spiked with 1,2-dichloroethane as an internal standard. The tube was capped and removed from the glovebox, then wrapped with electric tape and parafilm, and heated in an oil bath at $115{ }^{\circ} \mathrm{C}$ for 24 hours. The reaction was monitored via No-D ${ }^{1} \mathrm{H}$ NMR spectroscopy. Following completion, the mixture was then transferred to a round bottom flask using $\mathrm{CH}_{2} \mathrm{Cl}_{2}$ to aid in transfer, and the volatiles were removed on a rotary evaporator under reduced pressure. The resulting oil was purified via column chromatography (silica) to afford pure 1-tert-butyl-3-aryl carbodiimide. Known $\mathbf{2 f}^{1}{ }^{\text {(1-tert- }}$ butyl-3-(4-trifluoromethylphenyl)carbodiimide) was not isolated due to the relatively poor conversions observed prior to product decomposition.

Synthesis of 1-tert-butyl-3-phenylcarbodiimide (2a):

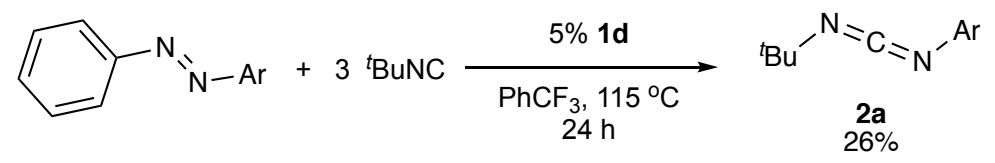

From $0.27 \mathrm{mmol}$ azobenzene. Purified using hexanes as eluent (25 mg isolated, 26\%). Chemical shifts were matched to that of the known compound. ${ }^{2}$

${ }^{1} \mathrm{H}$ NMR (400 MHz, $\left.\mathrm{CDCl}_{3}, 25^{\circ} \mathrm{C}, \delta, \mathrm{ppm}\right): 7.29$ (t, 2H, J = 7.8 Hz, Ar- $H$ ), 7.12-7.08 (m, $3 \mathrm{H}, \mathrm{Ar}-\mathrm{H}), 1.41\left(\mathrm{~s}, 9 \mathrm{H},-\mathrm{C}\left(\mathrm{CH}_{3}\right)_{3}\right)$.

${ }^{13} \mathrm{C}$ NMR (101 MHz, $\mathrm{CDCl}_{3}, 25{ }^{\circ} \mathrm{C}, \delta$, ppm): 141.1, 136.5, 129.5, 124.8, 123.4, 57.6, 31.8 . 


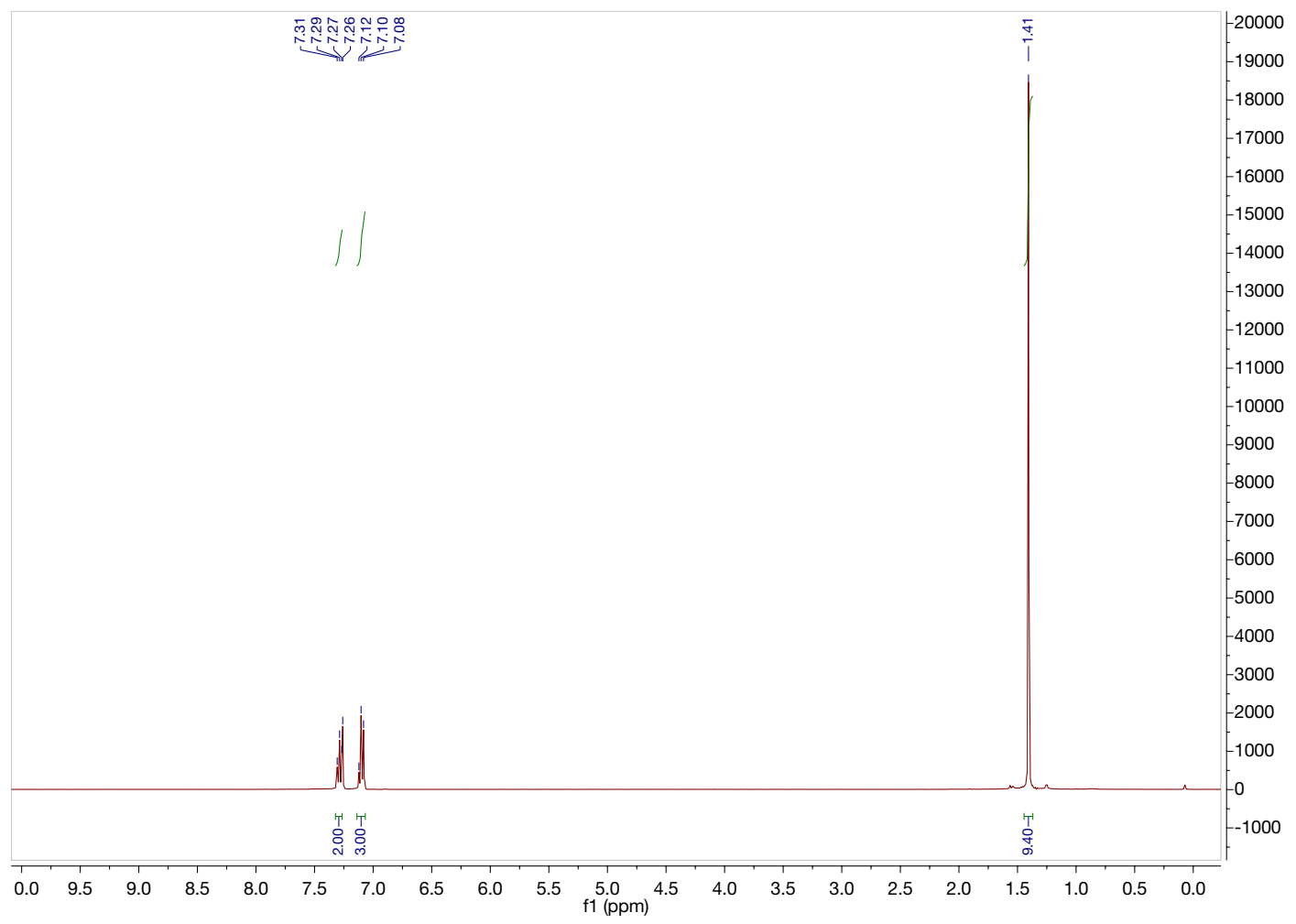

Figure S46. ${ }^{1} \mathrm{H}$ NMR of 1-tert-butyl-3-phenylcarbodiimide (2a) in $\mathrm{CDCl}_{3}$.

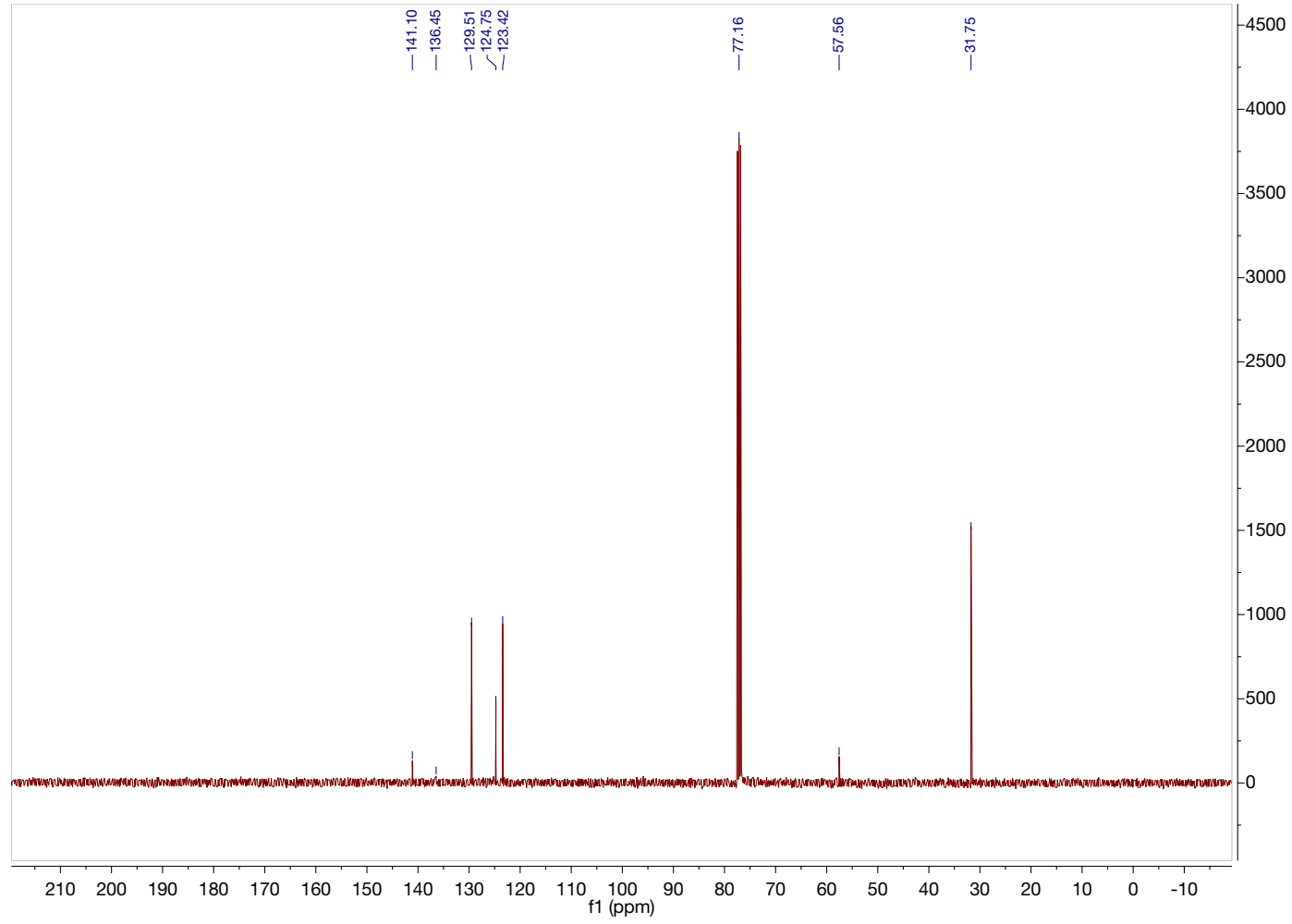

Figure S47. ${ }^{13} \mathrm{C}$ NMR of 1-tert-butyl-3-phenylcarbodiimide (2a) in $\mathrm{CDCl}_{3}$. 
Synthesis of 1-tert-butyl-3-(p-tolyl)carbodiimide (2b):

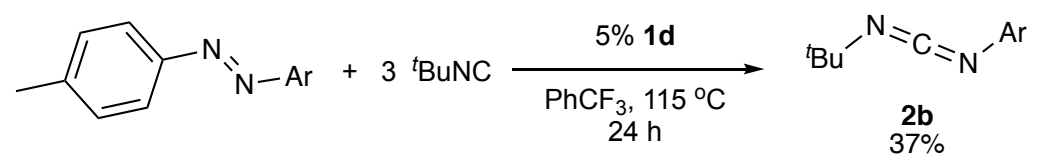

From $0.27 \mathrm{mmol}$ 1,2-di-p-tolyldiazene. Purified using hexanes as eluent, which coeluted with a trace of diazene (39 $\mathrm{mg}$ isolated, $37 \%$ corrected yield). The spectral data were matched to that of the known compound. ${ }^{1}$

${ }^{1} \mathrm{H}$ NMR (400 MHz, $\left.\mathrm{CDCl}_{3}, 25{ }^{\circ} \mathrm{C}, \delta, \mathrm{ppm}\right): 7.09$ (d, 2H, $J=8.3 \mathrm{~Hz}, \mathrm{Ar}-H$ ), $6.98(\mathrm{~d}, 2 \mathrm{H}, J$ $=8.3 \mathrm{~Hz}, \mathrm{Ar}-\mathrm{H}), 2.31\left(\mathrm{~s}, 3 \mathrm{H}, \mathrm{Ar}-\mathrm{CH}_{3}\right), 1.39\left(\mathrm{~s}, 9 \mathrm{H},-\mathrm{C}\left(\mathrm{CH}_{3}\right)_{3}\right)$.

${ }^{13} \mathrm{C}$ NMR (101 MHz, $\left.\mathrm{CDCl}_{3}, 25{ }^{\circ} \mathrm{C}, \delta, \mathrm{ppm}\right): 138.2,137.1,134.5,130.1,123.2,57.4$, 31.7, 21.1.

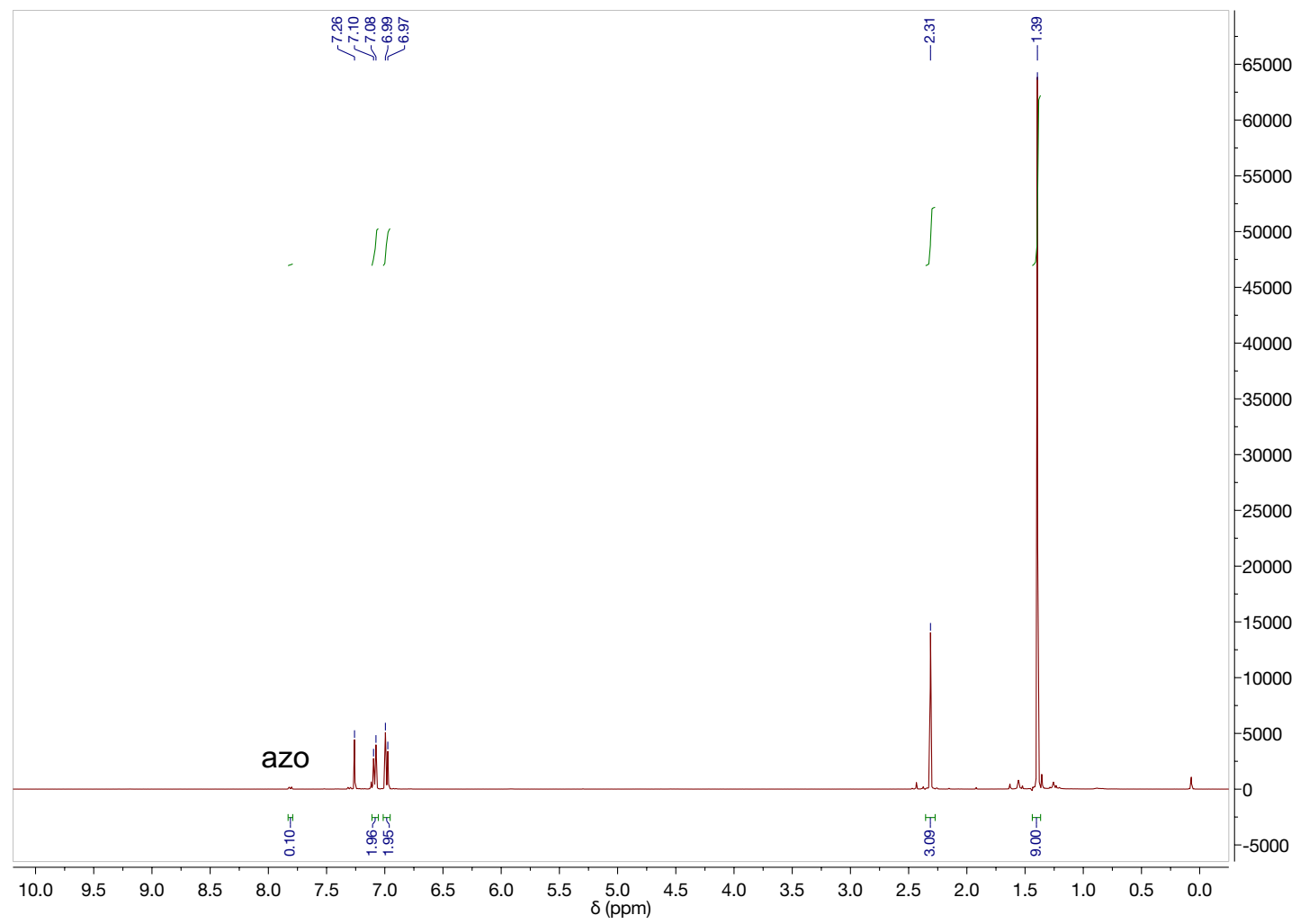

Figure S48. ${ }^{1} \mathrm{H}$ NMR of 1-tert-butyl-3-(4-tolyl)carbodiimide (2b) in $\mathrm{CDCl}_{3}$. 


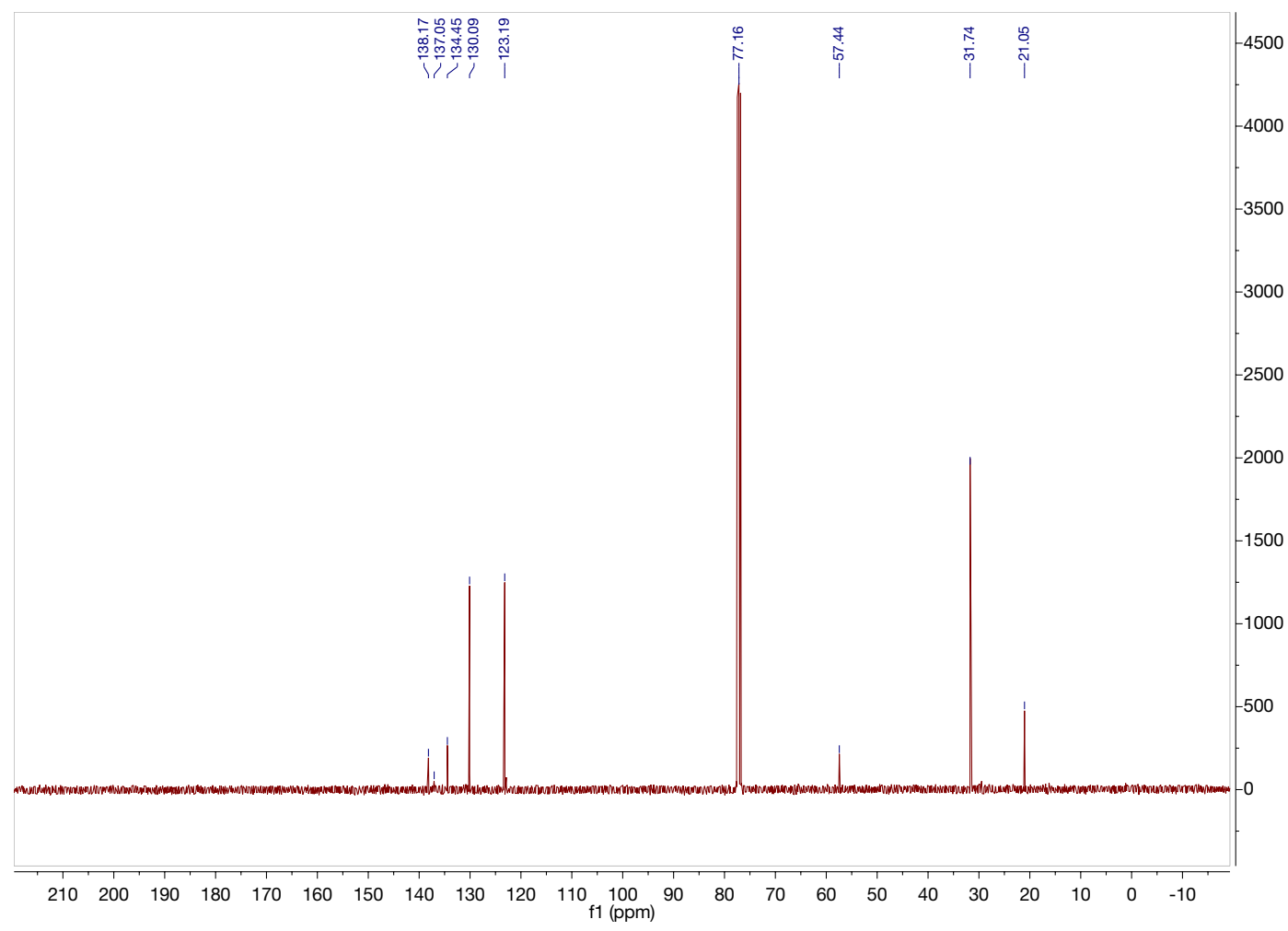

Figure S49. ${ }^{13} \mathrm{C}$ NMR of 1-tert-butyl-3-(4-tolyl)carbodiimide (2b) in $\mathrm{CDCl}_{3}$. 
Synthesis of 1-tert-butyl-3-(4-fluorophenyl)carbodiimide (2c):

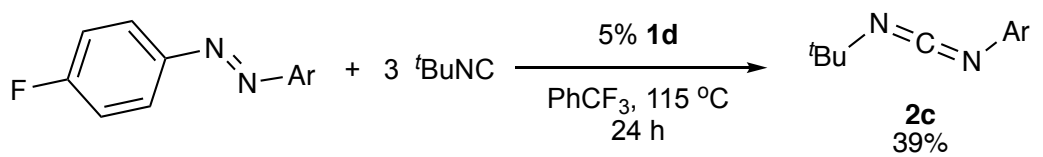

From $0.27 \mathrm{mmol}$ 1,2-bis(4-fluorophenyl)diazene. Purified using hexanes as eluent, which coeluted with a trace of diazene (43 mg isolated, $39 \%$ corrected yield). The spectral data were matched to that of the known compound. ${ }^{2}$

${ }^{1} \mathrm{H}$ NMR $\left(400 \mathrm{MHz}, \mathrm{CDCl}_{3}, 25^{\circ} \mathrm{C}, \delta\right.$, ppm): 7.06-7.01 (m, 2H, Ar- H), 7.00-6.93 (m, 2H, Ar- $H$ ), $1.40\left(\mathrm{~s}, 9 \mathrm{H},-\mathrm{C}\left(\mathrm{CH}_{3}\right)_{3}\right)$.

${ }^{13} \mathrm{C}$ NMR (101 MHz, $\left.\mathrm{CDCl}_{3}, 25{ }^{\circ} \mathrm{C}, \delta, \mathrm{ppm}\right): 160.0\left(\mathrm{~d}, J_{\mathrm{C}-\mathrm{F}}=244.4 \mathrm{~Hz}\right), 137.0\left(\mathrm{~d}, J_{\mathrm{C}-\mathrm{F}}=\right.$ $3.0 \mathrm{~Hz}) 136.4,124.5\left(\mathrm{~d}, J_{\mathrm{C}-\mathrm{F}}=9.1 \mathrm{~Hz}\right), 116.2\left(\mathrm{~d}, J_{\mathrm{C}-\mathrm{F}}=23.2 \mathrm{~Hz}\right), 57.6,31.7$.

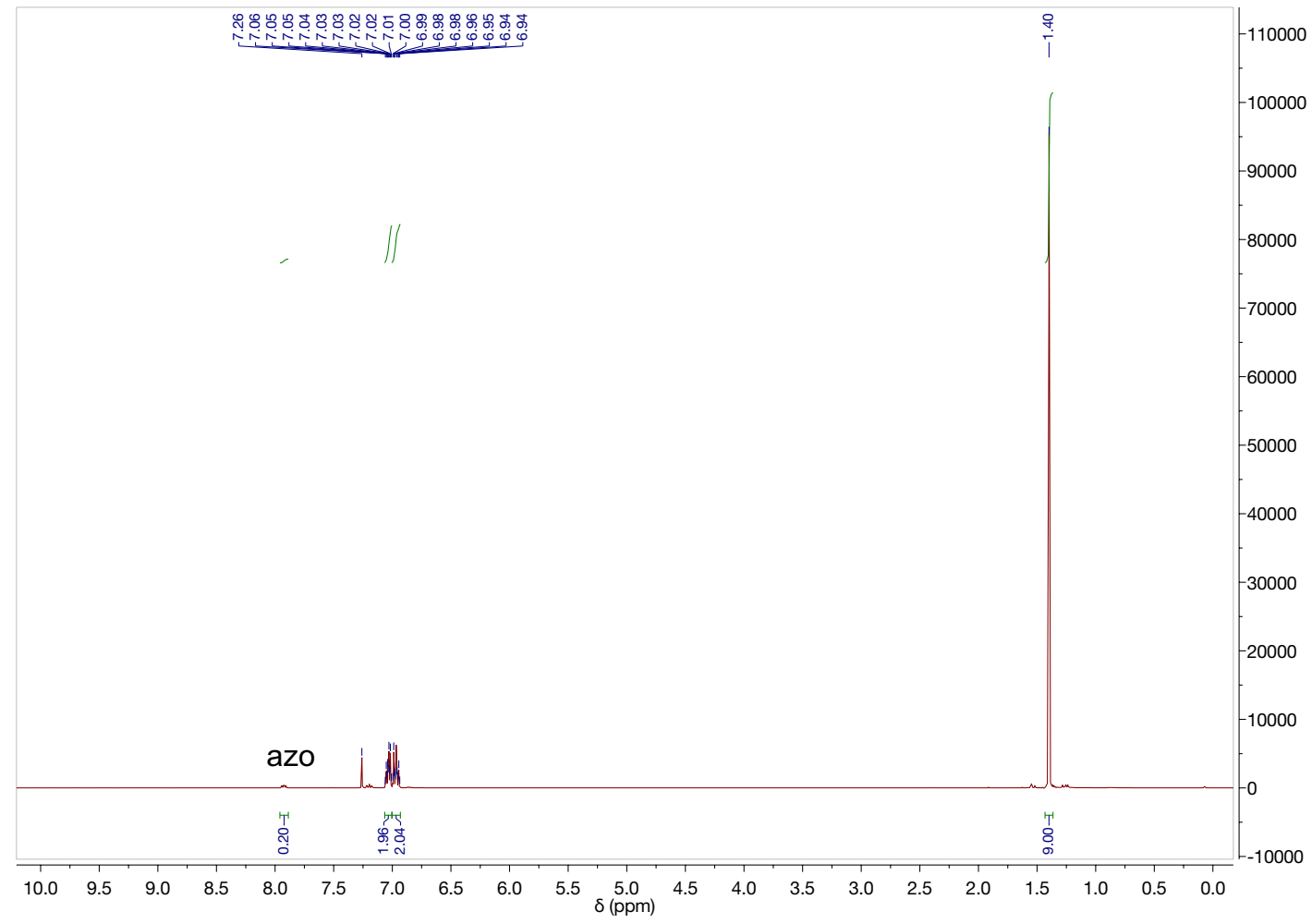

Figure S50. ${ }^{1} \mathrm{H}$ NMR of 1-tert-butyl-3-(4-fluorophenyl)carbodiimide (2c) in $\mathrm{CDCl}_{3}$. 


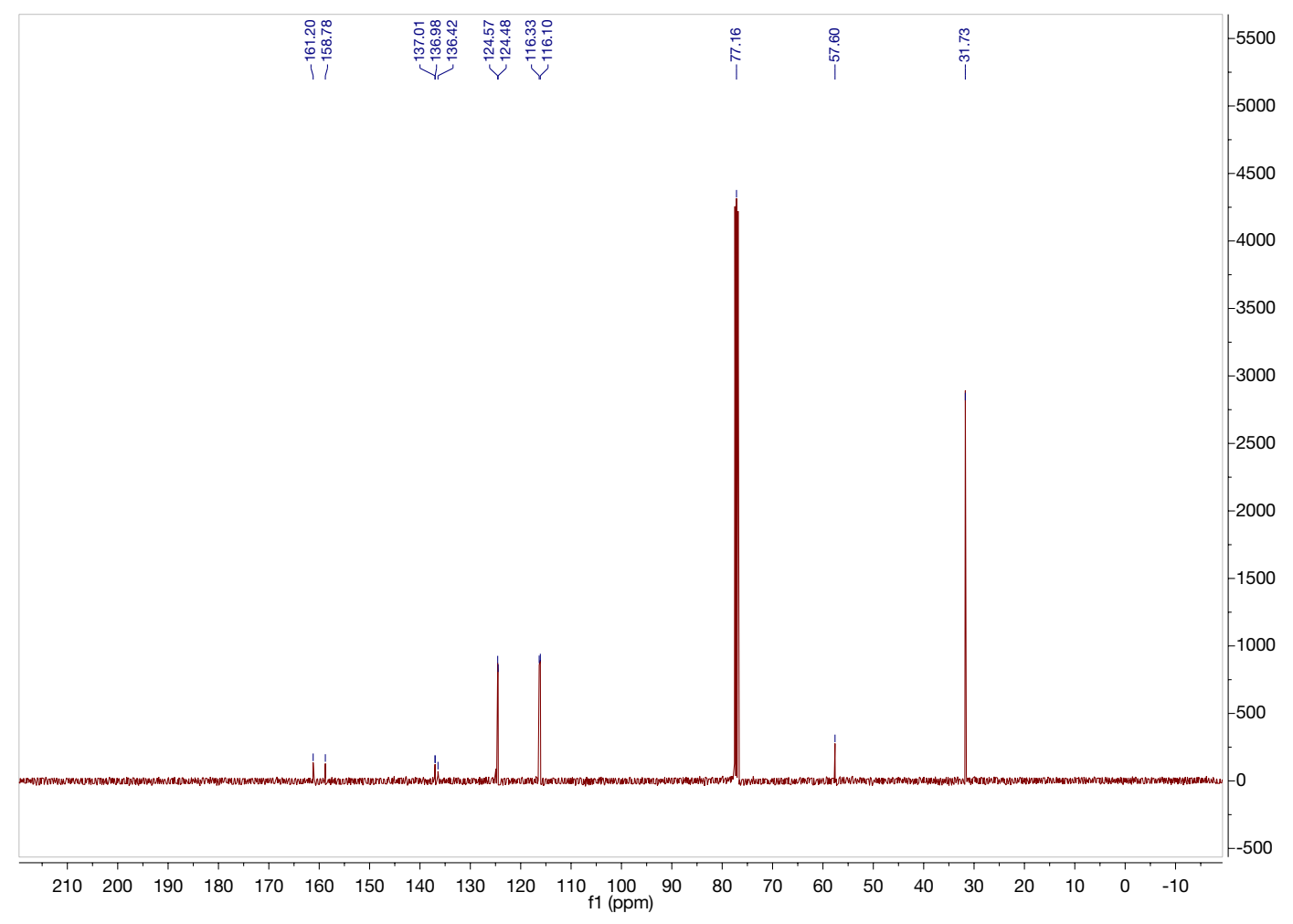

Figure S51. ${ }^{13} \mathrm{C}$ NMR of 1-tert-butyl-3-(4-fluorophenyl)carbodiimide (2c) in $\mathrm{CDCl}_{3}$. 
Synthesis of 1-tert-butyl-3-(4-chlorophenyl)carbodiimide (2d):

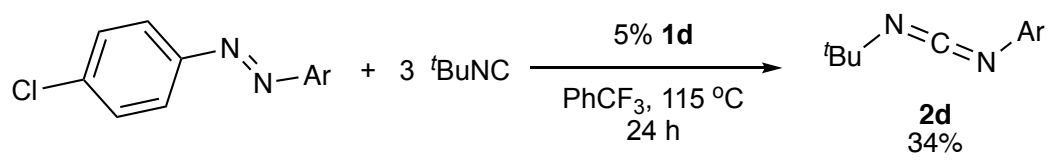

From $0.27 \mathrm{mmol}$ 1,2-bis(4-chlorophenyl)diazene. Purified using hexanes as eluent (39 mg isolated, $34 \%$ ). The spectral data were matched to that of the known compound. ${ }^{1}$

${ }^{1} \mathrm{H}$ NMR (400 MHz, $\left.\mathrm{CDCl}_{3}, 25{ }^{\circ} \mathrm{C}, \delta, \mathrm{ppm}\right): 7.24(\mathrm{~d}, 2 \mathrm{H}, J=8.7 \mathrm{~Hz}, \mathrm{Ar}-H$ ), $7.00(\mathrm{~d}, 2 \mathrm{H}, J$ $=8.7 \mathrm{~Hz}, \mathrm{Ar}-\mathrm{H}), 1.40\left(\mathrm{~s}, 9 \mathrm{H},-\mathrm{C}\left(\mathrm{CH}_{3}\right)_{3}\right)$.

${ }^{13} \mathrm{C}$ NMR (101 MHz, $\left.\mathrm{CDCl}_{3}, 25{ }^{\circ} \mathrm{C}, \delta, \mathrm{ppm}\right): 139.9,135.8,129.9,129.6,124.6,57.8$, 31.7.

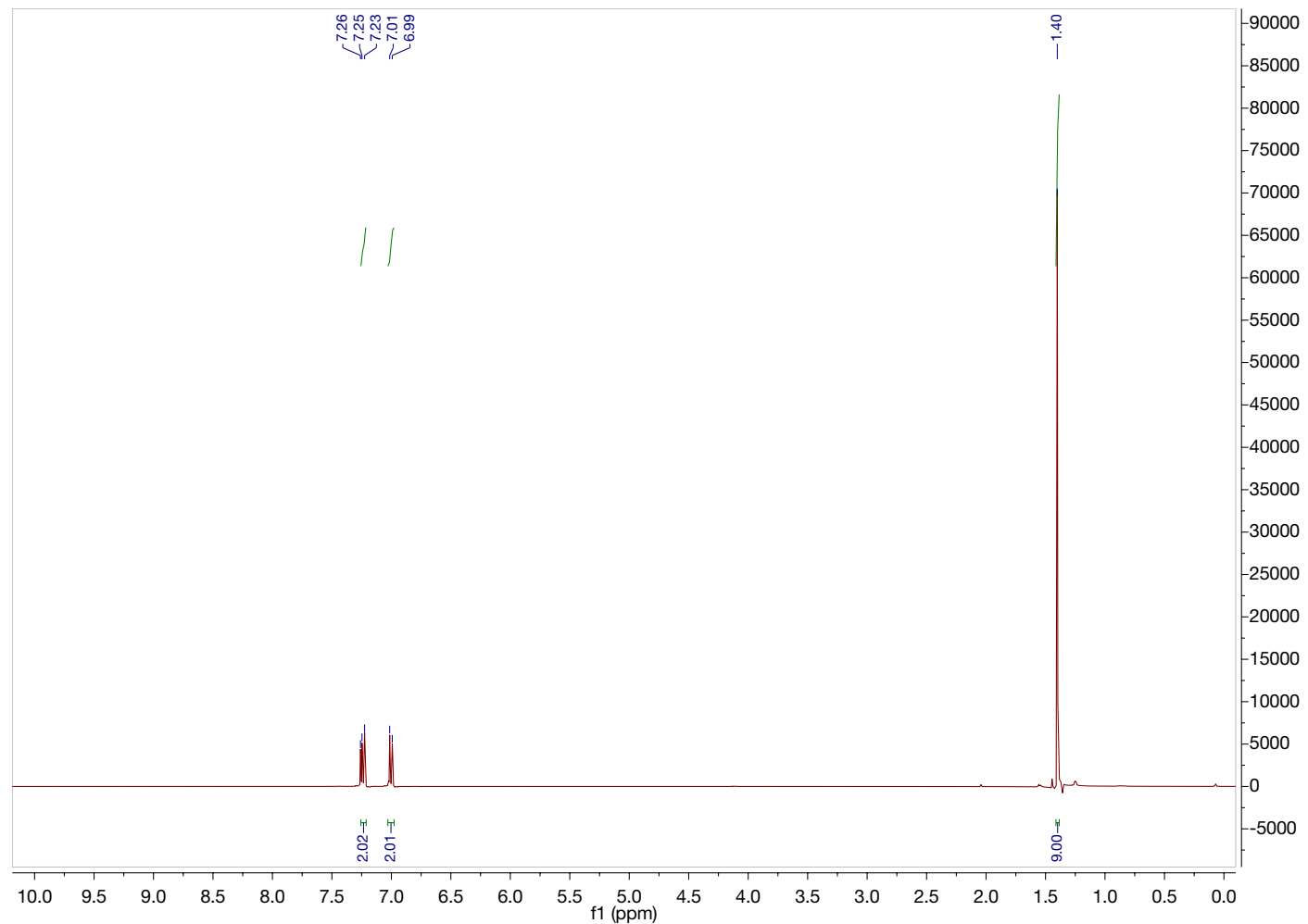

Figure S52. ${ }^{13} \mathrm{C}$ NMR of 1-tert-butyl-3-(4-chlorophenyl)carbodiimide (2d) in $\mathrm{CDCl}_{3}$. 


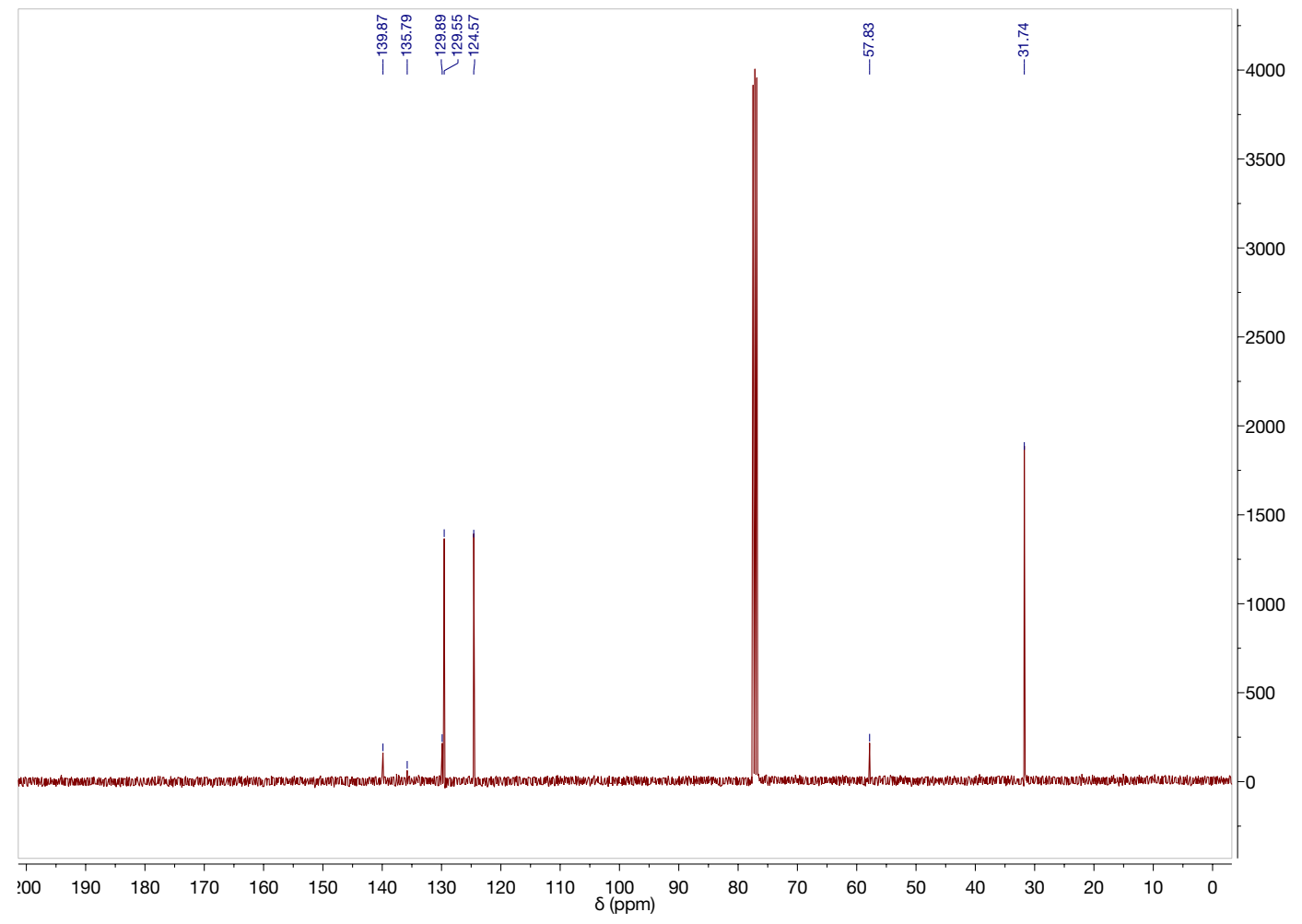

Figure S53. ${ }^{13} \mathrm{C}$ NMR of 1-tert-butyl-3-(4-chlorophenyl)carbodiimide (2d) in $\mathrm{CDCl}_{3}$. 
Synthesis of 1-tert-butyl-3-(o-tolyl)carbodiimide (2g):

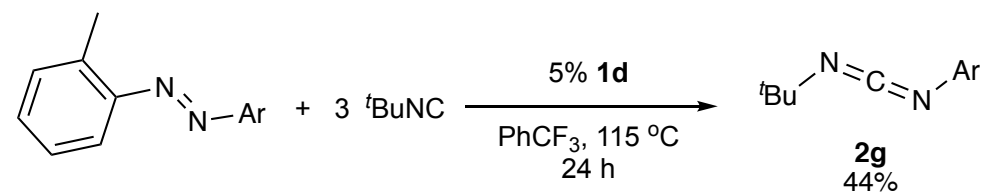

From 0.27 mmol 1,2-di-o-tolyldiazene. Purified using 2\% EtOAc/hexanes as eluent (45 $\mathrm{mg}$ isolated, $44 \%$ ). The spectral data were matched to that of the known compound. ${ }^{1}$

${ }^{1} \mathrm{H}$ NMR $\left(400 \mathrm{MHz}, \mathrm{CDCl}_{3}, 25^{\circ} \mathrm{C}, \delta, \mathrm{ppm}\right): 7.16-7.11(\mathrm{~m}, 3 \mathrm{H}, \mathrm{Ar}-H), 7.04-6.98(\mathrm{~m}$, $1 \mathrm{H}, \mathrm{Ar}-\mathrm{H}), 2.30\left(\mathrm{~s}, 3 \mathrm{H}, \mathrm{Ar}-\mathrm{CH}_{3}\right), 1.40\left(\mathrm{~s}, 9 \mathrm{H},-\mathrm{C}\left(\mathrm{CH}_{3}\right)_{3}\right)$.

${ }^{13} \mathrm{C} \mathrm{NMR}\left(101 \mathrm{MHz}, \mathrm{CDCl}_{3}, 25{ }^{\circ} \mathrm{C}, \delta, \mathrm{ppm}\right): 139.4,135.8,132.2,130.8,126.8,124.6$, 123.6, 57.1, 31.7, 18.3.

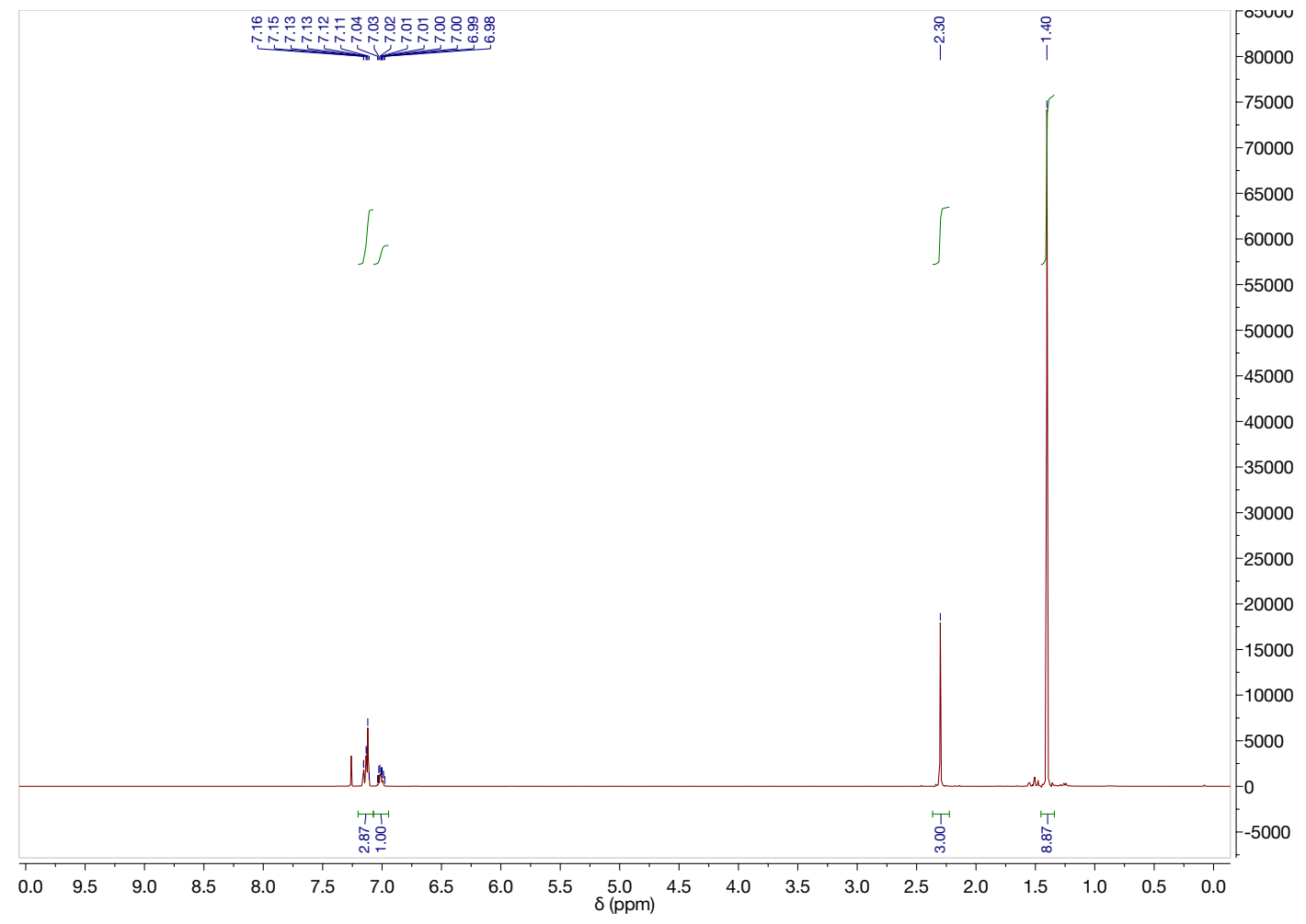

Figure S54. ${ }^{1} \mathrm{H}$ NMR of 1-tert-butyl-3-(o-tolyl)carbodiimide (2g) in $\mathrm{CDCl}_{3}$. 


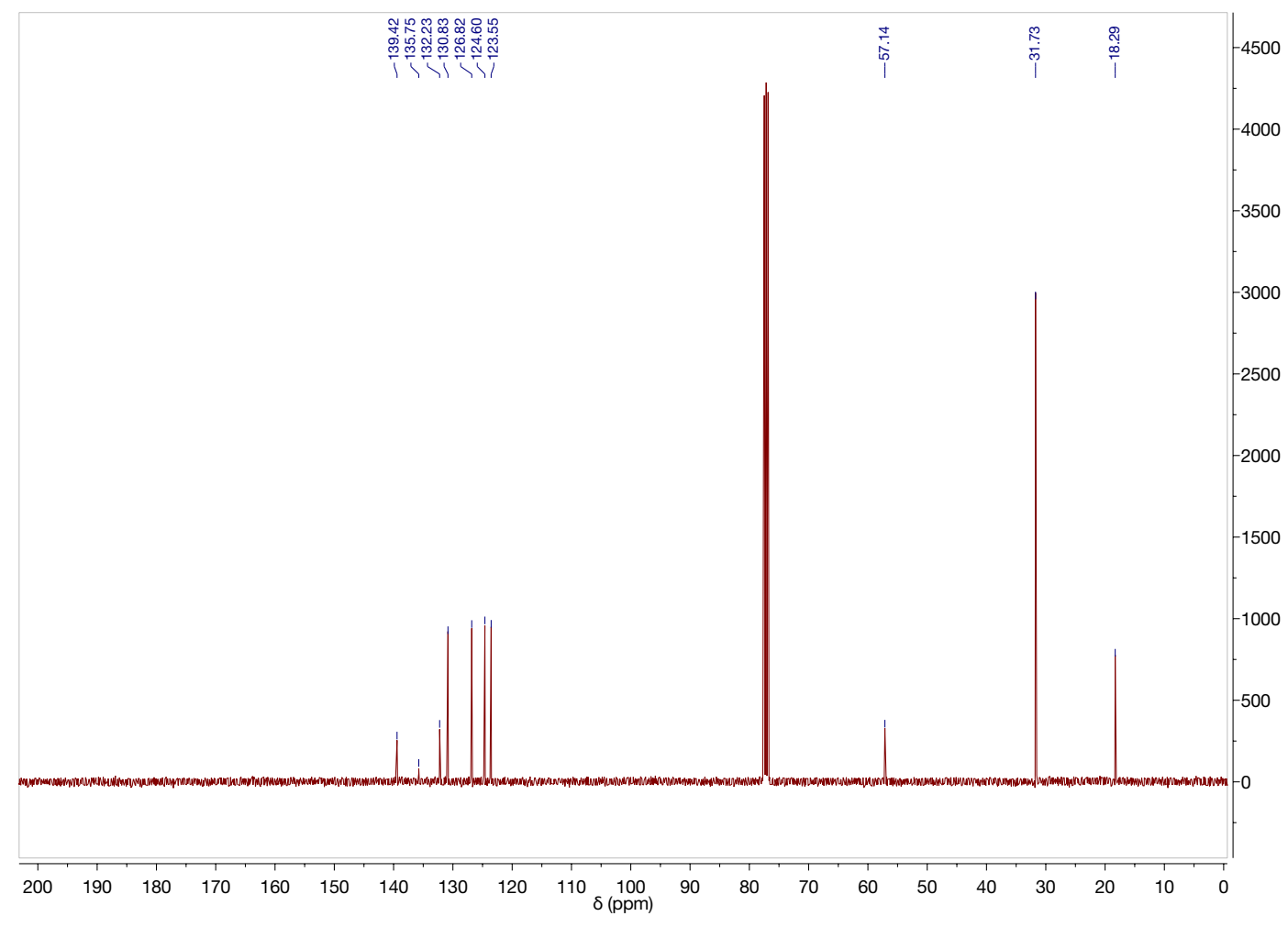

Figure S55. ${ }^{13} \mathrm{C}$ NMR of 1-tert-butyl-3-(o-tolyl)carbodiimide (2g) in $\mathrm{CDCl}_{3}$. 


\section{Scaled up synthesis of 1-tert-butyl-3-phenylcarbodiimide (2a):}

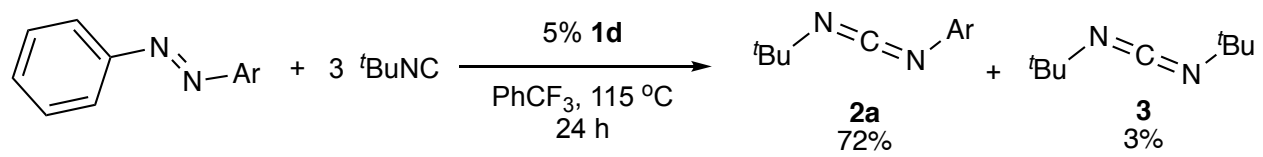

In an $\mathrm{N}_{2}$-filled glovebox, a $100 \mathrm{~mL}$ pressure tube containing a Teflon stir bar was charged with azobenzene $(1.00 \mathrm{~g}, 5.49 \mathrm{mmol}, 1$ equiv. $)$, [py $\left.\mathrm{TiBr}_{2}\left(\mathrm{~N}^{t} \mathrm{Bu}\right)\right]_{2}(0.239 \mathrm{mg}, 0.275 \mathrm{mmol}$, 0.05 equiv.), tert-butylisocyanide (1.37 g, $16.5 \mathrm{mmol}, 3$ equiv.), and $\mathrm{PhCF}_{3}(20 \mathrm{~mL})$. The tube was sealed and removed from the glovebox, then heated in an oil bath at $115{ }^{\circ} \mathrm{C}$ for 40 hours. The reaction was cooled to room temperature, then run through a plug of neutral alumina using $\mathrm{CH}_{2} \mathrm{Cl}_{2}$ as eluent in order to remove Ti. The filtrate was collected and volatiles were removed under reduced pressure using a rotary evaporator. The residual oil was distilled under reduced pressure to afford 1.43 grams of the title compound as a lightorange oil (75\% yield with $97 \%$ purity, $72 \%$ corrected yield of 2 a with $3 \%{ }^{t} \mathrm{BuNCN}^{t} \mathrm{Bu}(3)$ which codistilled with the title compound). The chemical shifts of $2 \mathbf{a}$ were matched with the line list presented on page S51.

1,3-di-tert-butylcarbodiimide:

${ }^{1} \mathrm{H}$ NMR (400 MHz, $\mathrm{CDCl}_{3}, 25^{\circ} \mathrm{C}, \delta$, ppm): 1.29 (s, $\left.18 \mathrm{H},-\mathrm{C}\left(\mathrm{CH}_{3}\right)_{3}\right)$.

The chemical shift matched that of the commercially available material (TCI Chemicals).

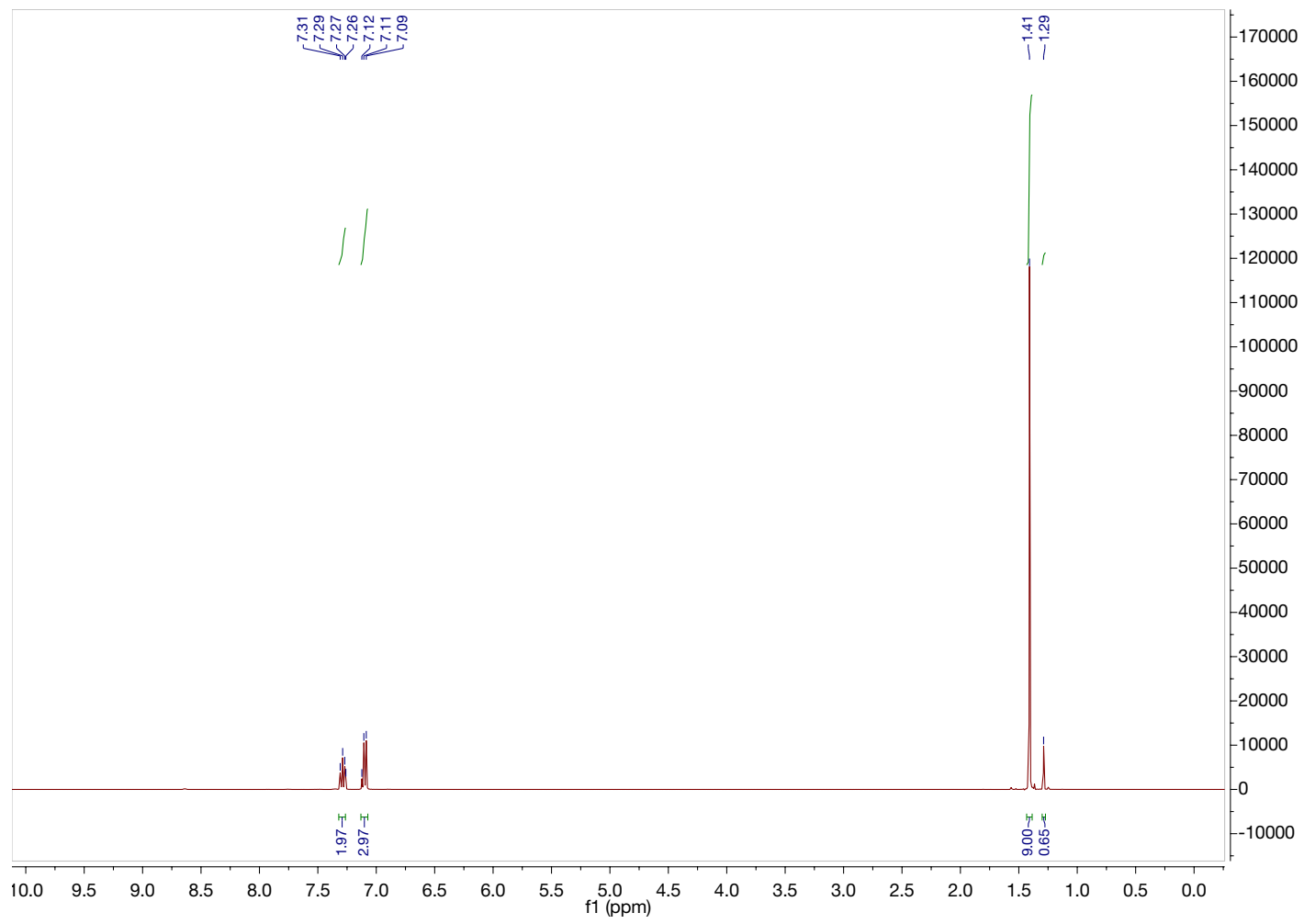

Figure S56. ${ }^{1} \mathrm{H}$ NMR of 1-tert-butyl-3-phenylcarbodiimide and 1,3-di-tertbutylcarbodiimide in $\mathrm{CDCl}_{3}$. 


\section{Isolation of Adamantyl-Substituted Carbodiimides (Table 3):}

Adamantyl-substituted carbodiimides were synthesized following the general procedure: in an $\mathrm{N}_{2}$-filled glovebox, an $20 \mathrm{~mL}$ scintillation vial was loaded with 1-azidoadamantane (50 mg, $0.28 \mathrm{mmol}, 1$ equiv.), [py $\left.2 \mathrm{TiBr}_{2}\left(\mathrm{~N}^{t} \mathrm{Bu}\right)\right]_{2}(13 \mathrm{mg}, 0.014 \mathrm{mmol}, 0.05$ equiv., $10 \mathrm{~mol}$ $\%$ in $\mathrm{Ti})$, requisite isocyanide $(0.42 \mathrm{mmol}, 1.5$ equiv. $)$, and $\mathrm{PhCF}_{3}(1 \mathrm{~mL})$. The vial was sealed with a Teflon cap and removed from the glovebox, then wrapped with electric tape and heated in an oil bath at $115^{\circ} \mathrm{C}$ for 24 hours. The reaction mixture was then transferred to a round bottom flask using $\mathrm{CH}_{2} \mathrm{Cl}_{2}$ to aid in transfer, and the volatiles were removed on a rotary evaporator under reduced pressure. The residual material was run through a plug of neutral alumina using hexanes as eluent, and then dried in vacuo for several hours to afford the corresponding carbodiimide.

Synthesis of 1-adamantyl-3-tert-butylcarbodiimide (4a) (Table 3 Entry 1):

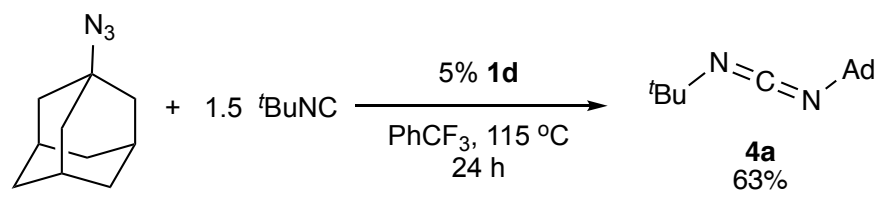

The reaction was performed with $0.42 \mathrm{mmol}$ tert-butylisocyanide. Isolated $41 \mathrm{mg}, 63 \%$.

${ }^{1} \mathrm{H}$ NMR (400 MHz, $\left.\mathrm{C}_{6} \mathrm{D}_{6}, 25{ }^{\circ} \mathrm{C}, \delta, \mathrm{ppm}\right): 1.87$ (s, 3H, adamantyl-CH), 1.83 (s, $6 \mathrm{H}$, adamantyl- $\left.\mathrm{CH}_{2}\right), 1.46\left(\mathrm{~s}, 6 \mathrm{H}\right.$, adamantyl- $\left.\mathrm{CH}_{2}\right), 1.22\left(\mathrm{~s}, 9 \mathrm{H},-\mathrm{C}\left(\mathrm{CH}_{3}\right)_{3}\right)$.

The chemical shifts of the title compound were matched to the literature. ${ }^{3}$ 


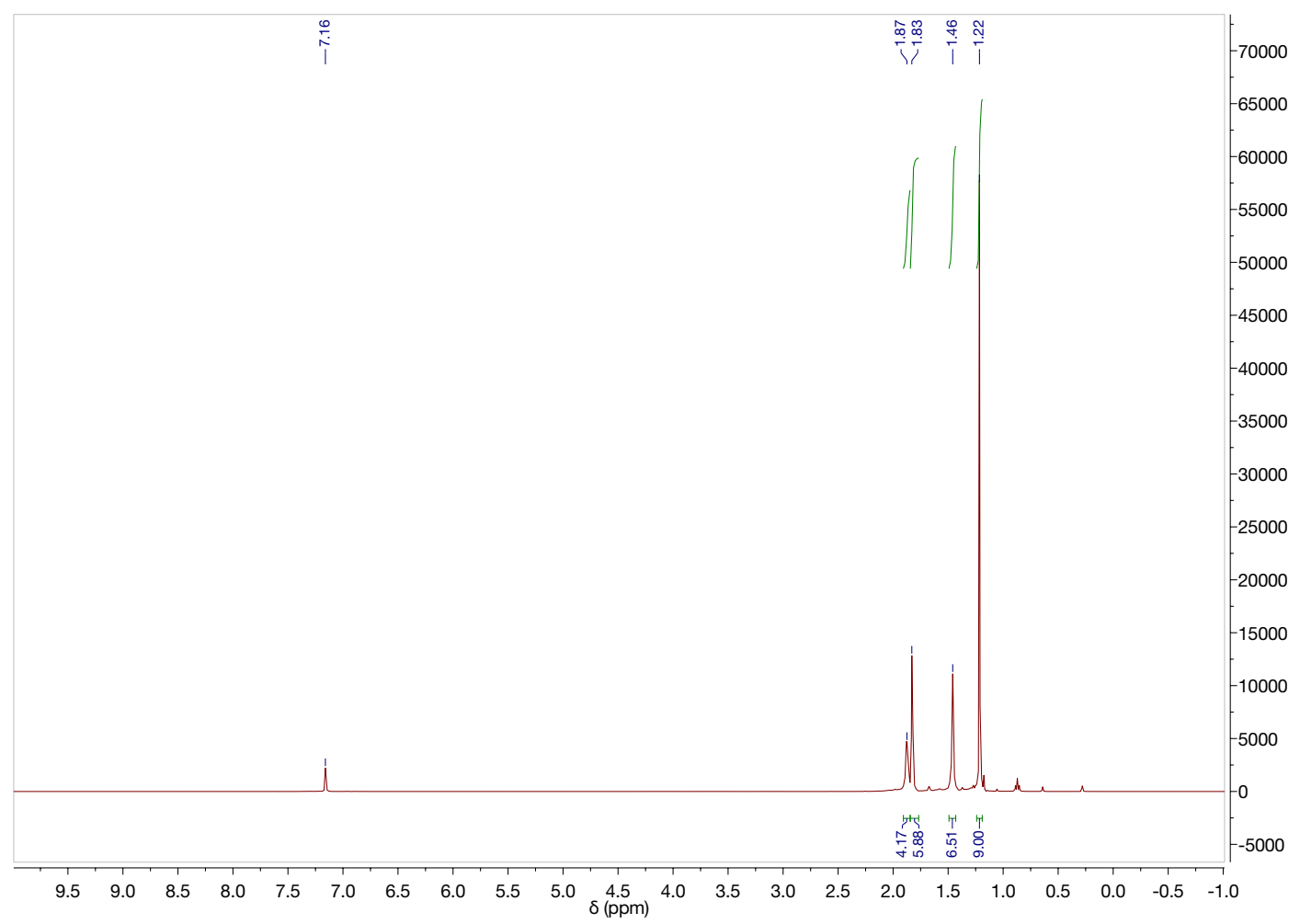

Figure S57. ${ }^{1} \mathrm{H}$ NMR of 1-adamantyl-3-tert-butylcarbodiimide (4a) in $\mathrm{C}_{6} \mathrm{D}_{6}$. 
Synthesis of 1-adamantyl-3-cyclohexylcarbodiimide (4b) (Table 3 Entry 2):

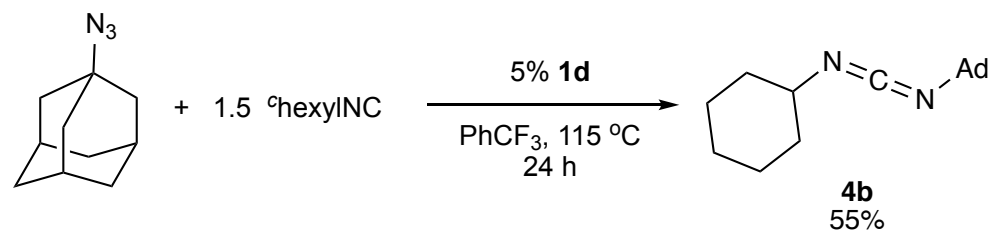

The reaction was performed with $0.42 \mathrm{mmol}$ cyclohexylisocyanide. Isolated $40 \mathrm{mg}, 55 \%$.

${ }^{1} \mathrm{H}$ NMR (400 MHz, $\mathrm{C}_{6} \mathrm{D}_{6}, 25^{\circ} \mathrm{C}, \delta$, ppm): 3.13 (tt, $\left.1 \mathrm{H}, J=10.0,3.8 \mathrm{~Hz}, \mathrm{Cy}-H\right), 1.89$ (s, $3 \mathrm{H}$, Ad- $H$ ), 1.87 (s, 6H, Ad- $H$ ), $1.64-1.54$ (m, 2H, Cy- $H$ ), 1.47 (s, 6H, Ad- $H$ ), 1.43 $1.29(\mathrm{~m}, 4 \mathrm{H}, \mathrm{Cy}-H), 1.14-0.85(\mathrm{~m}, 4 \mathrm{H}, \mathrm{Cy}-H)$.

${ }^{13} \mathrm{C}$ NMR (101 MHz, $\left.\mathrm{C}_{6} \mathrm{D}_{6}, 25{ }^{\circ} \mathrm{C}, \delta, \mathrm{ppm}\right): 139.6,55.9,54.9,45.4,36.3,35.5,30.3,25.8$, 25.0 .

GC-HRMS (m/z): calcd. for $\mathrm{C}_{17} \mathrm{H}_{26} \mathrm{~N}_{2}$, 258.2096; found, 258.2184.

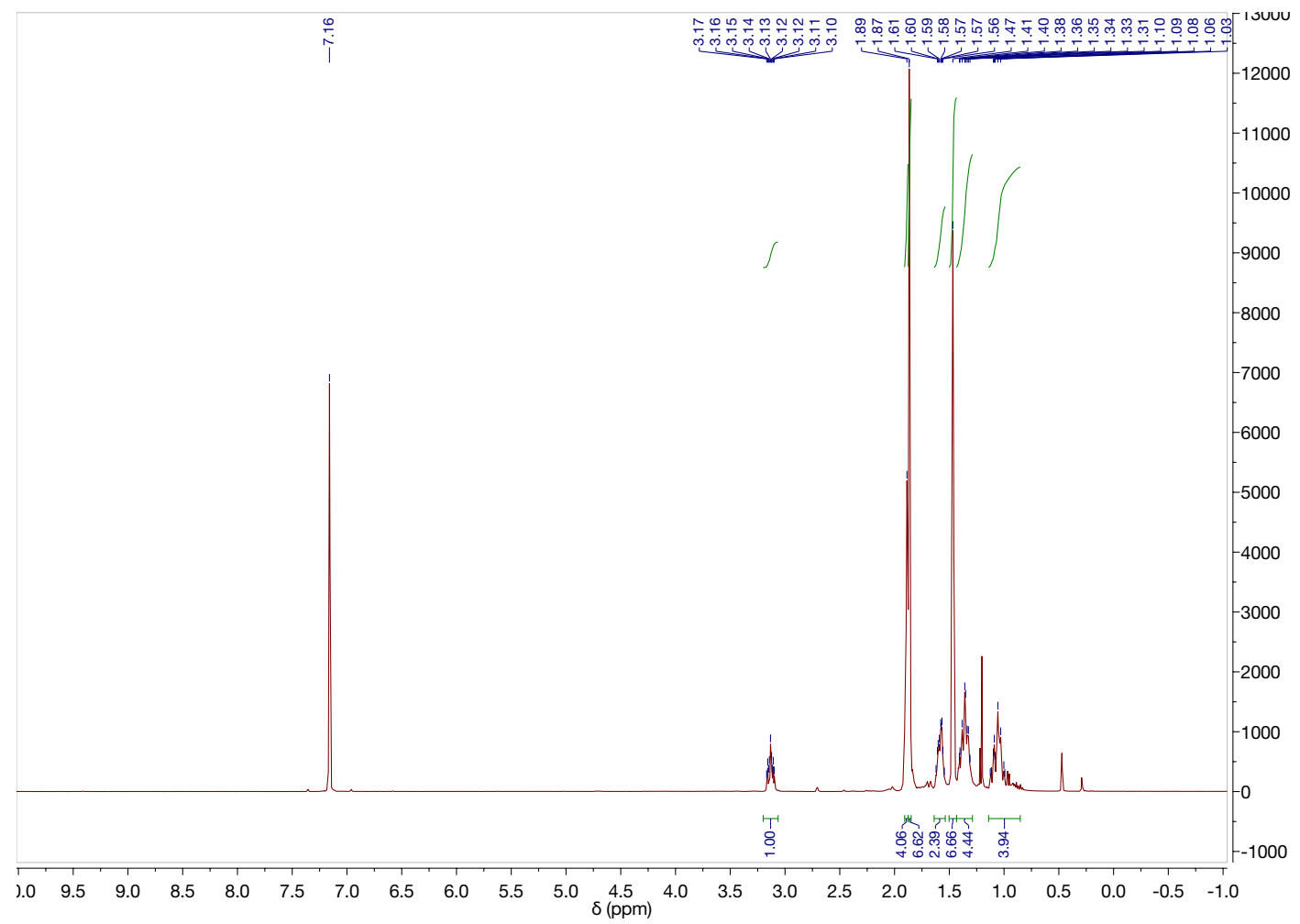

Figure S58. ${ }^{1} \mathrm{H}$ NMR of 1-adamantyl-3-cyclohexylcarbodiimide (4b) in $\mathrm{C}_{6} \mathrm{D}_{6}$. 


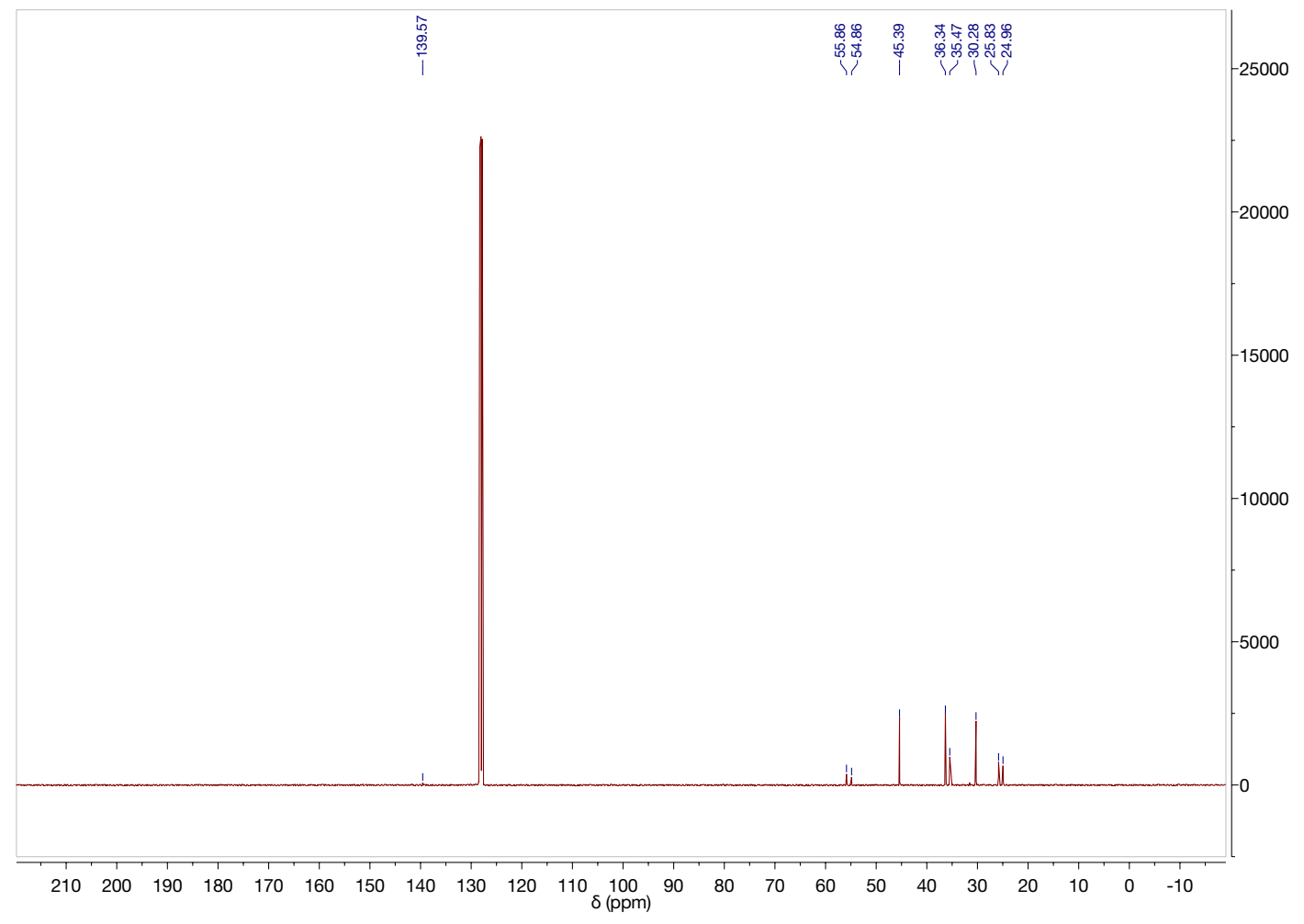

Figure S59. ${ }^{13} \mathrm{C}$ NMR of 1-adamantyl-3-cyclohexylcarbodiimide (4b) in $\mathrm{C}_{6} \mathrm{D}_{6}$. 
Synthesis of 1-adamantyl-3-(2,6-dimethylphenyl)carbodiimide (4c) (Table 3 Entry 3):

The reaction was performed with $0.42 \mathrm{mmol}$ 2,6-dimethylphenyl isocyanide. Isolated 74 mg, $92 \%$ pure with $8 \%$ impurity of ${ }^{t} \mathrm{BuNCN}\left(2,6-\mathrm{Me}_{2} \mathrm{Ph}\right), 86 \%$ yield. The ${ }^{t} \mathrm{BuNCN}(2,6-$ $\mathrm{Me}_{2} \mathrm{Ph}$ ) impurity was identified by matching the aliphatic resonances to the literature. ${ }^{4}$

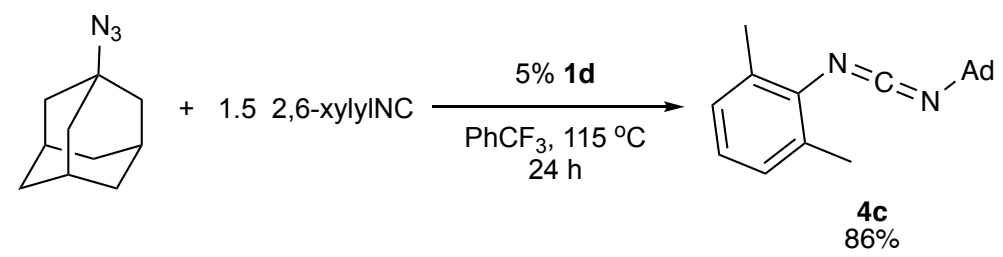

${ }^{1} \mathrm{H}$ NMR (400 MHz, $\left.\mathrm{CDCl}_{3}, 25^{\circ} \mathrm{C}, \delta, \mathrm{ppm}\right): 7.00$ (d, $\left.2 \mathrm{H}, J=7.5 \mathrm{~Hz}, \mathrm{Ar}-H\right), 6.93-6.89$ (m, $1 \mathrm{H}, \mathrm{Ar}-\mathrm{H}), 2.35$ (s, 6H, $\left.\operatorname{Ar}\left(\mathrm{CH}_{3}\right)_{2}\right), 2.11$ (s, 3H, adamantyl- $\left.\mathrm{CH}\right), 1.89$ (s, 6H, adamantyl$\left.\mathrm{CH}_{2}\right), 1.66\left(\mathrm{~s}, 6 \mathrm{H}\right.$, adamantyl- $\mathrm{CH}_{2}$ ).

${ }^{13} \mathrm{C}$ NMR (101 MHz, $\left.\mathrm{CDCl}_{3}, 25^{\circ} \mathrm{C}, \delta, \mathrm{ppm}\right): 137.1,136.1,132.6,128.2,124.1,56.5,44.9$, $36.1,30.0,19.3$.

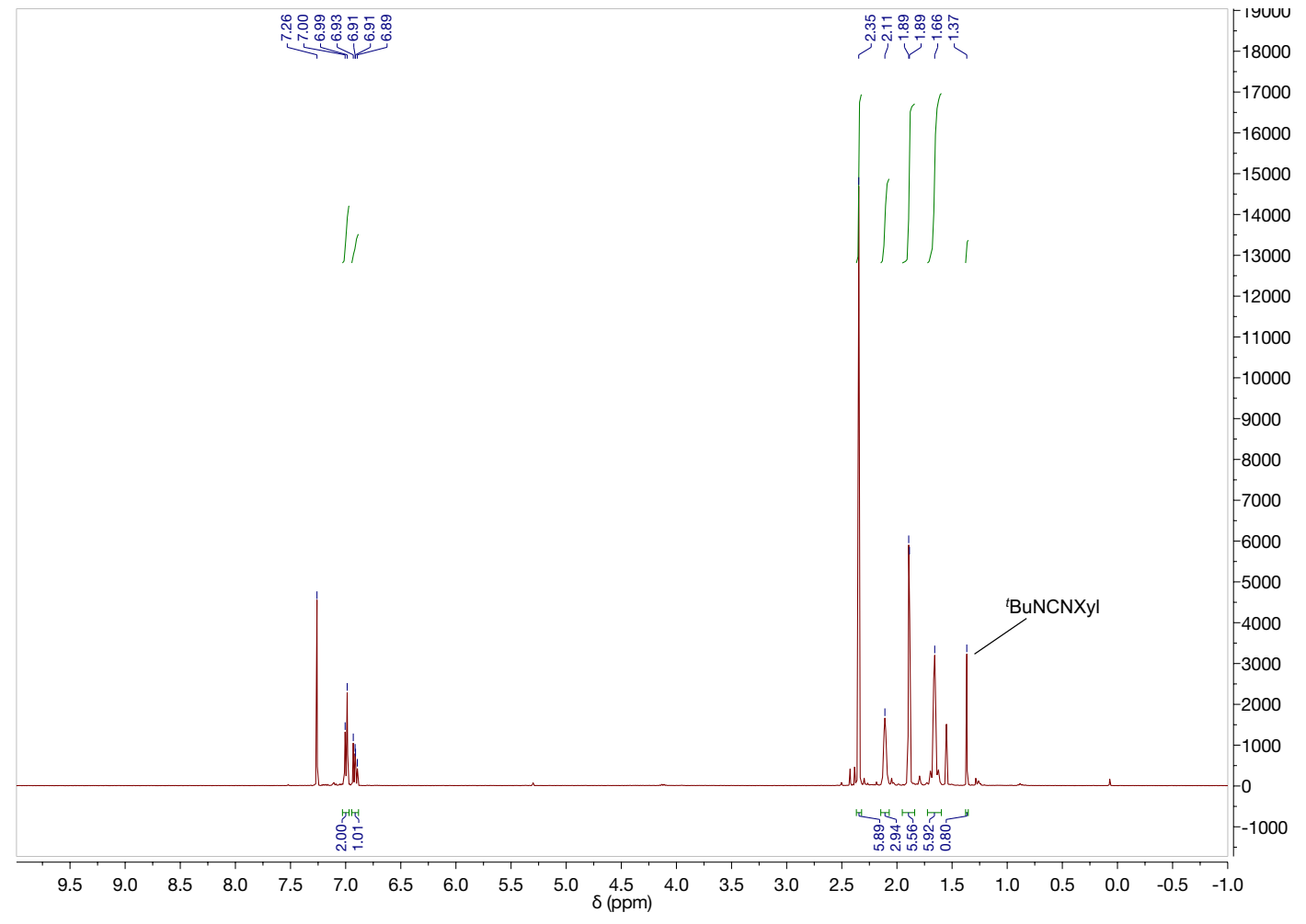

Figure S60. ${ }^{1} \mathrm{H}$ NMR of 1-adamantyl-3-(2,6-dimethylphenyl)carbodiimide (4c) and trace 1-tert-butyl-3-(2,6-dimethylphenyl)carbodiimide in $\mathrm{CDCl}_{3}$. 


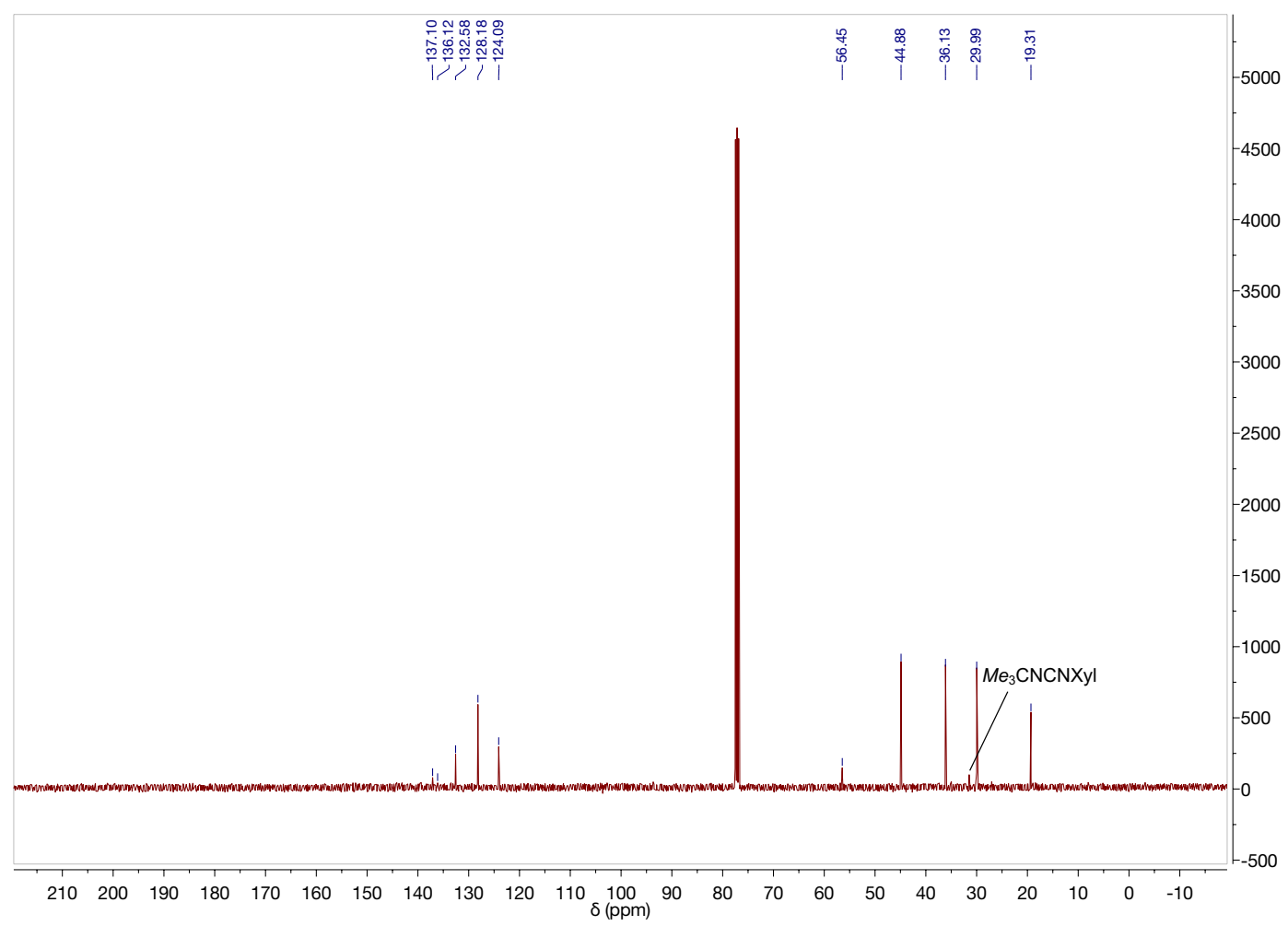

Figure S61. ${ }^{13} \mathrm{C}$ NMR of 1-adamantyl-3-(2,6-dimethylphenyl)carbodiimide (4c) in $\mathrm{CDCl}_{3}$. 


\title{
Metathesis Reaction of 1-tert-butyl-3-phenylcarbodiimide Catalyzed by $1 \mathrm{~b}$ and Discussion:
}

\author{
$\mathrm{PhN}=\mathrm{C}=\mathrm{N}^{t} \mathrm{Bu} \underset{\mathrm{PhCF}_{3}, 115^{\circ} \mathrm{C}, 24 \mathrm{~h}}{\stackrel{5 \% \mathrm{py}_{3} \mathrm{TiBr}_{2}(\mathrm{NPh})}{\rightleftharpoons}} 0.5 \mathrm{PhN}=\mathrm{C}=\mathrm{NPh}+0.5{ }^{t} \mathrm{BuN}=\mathrm{C}=\mathrm{N}^{t} \mathrm{Bu}$
}

$0.5 \mathrm{~mL}$ of a stock solution of $\mathrm{PhCF}_{3}$ containing $0.661 \mathrm{M}$ 1-tert-butyl-3-phenylcarbodiimide

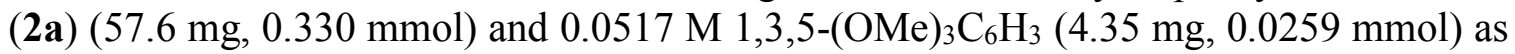
an internal standard was prepared and used for the NMR tube reaction for the metathesis of 1-tert-butyl-3-phenylcarbodiimide. In an $\mathrm{N}_{2}$ glovebox, $0.5 \mathrm{~mL}$ of the stock solution was added to an NMR tube containing $\mathbf{1 b}(8.7 \mathrm{mg}, 0.0162 \mathrm{mmol}, 5 \mathrm{~mol} \%)$. The NMR tube was sealed, then wrapped with electric tape and parafilm, and an initial $\mathrm{t}=0{ }^{1} \mathrm{H}$ NMR spectrum was taken. The reaction was then heated in an oil bath for $24 \mathrm{~h}$ at $115^{\circ} \mathrm{C}$. After $24 \mathrm{~h}$, a final ${ }^{1} \mathrm{H}$ NMR spectrum was taken, and showed the presence of 1,3-di-tertbutylcarbodiimide. After $24 \mathrm{~h}, 0.0113 \mathrm{mmol}$ of 1,3-di-tert-butylcarbodiimide was generated (only $44 \%$ of what was observed in Table 1 entry $2 /$ Figure S3). The yield was determined by referencing to the internal standard, 1,3,5-(OMe) ${ }_{3} \mathrm{C}_{6} \mathrm{H}_{3}$ (acquisition $=5$, delay $=30, \mathrm{~ns}=4)$.

In the formation of 1-tert-butyl-3-phenylcarbodiimide catalyzed by $\mathbf{1 b}, 0.0256 \mathrm{mmol}$ of 1,3-di-tert-butylcarbodiimide was generated in the $24 \mathrm{~h}$ time period (Table 1 , entry 2/Figure S3), ruling out carbodiimide metathesis as the sole reaction pathway for the generation of 1,3-di-tert-butylcarbodiimide based on the additional $0.0143 \mathrm{mmol}$ of this product formed. In addition, the starting concentration of 1-tert-butyl-3phenylcarbodiimide in this metathesis reaction was equivalent to that of the catalytic reaction of azobenzene and tert-butylisocyanide at the completion of the reaction (assuming quantitative yield), therefore it is likely that the extent of carbodiimide metathesis under catalytic conditions would be less than what is demonstrated by this reaction. 


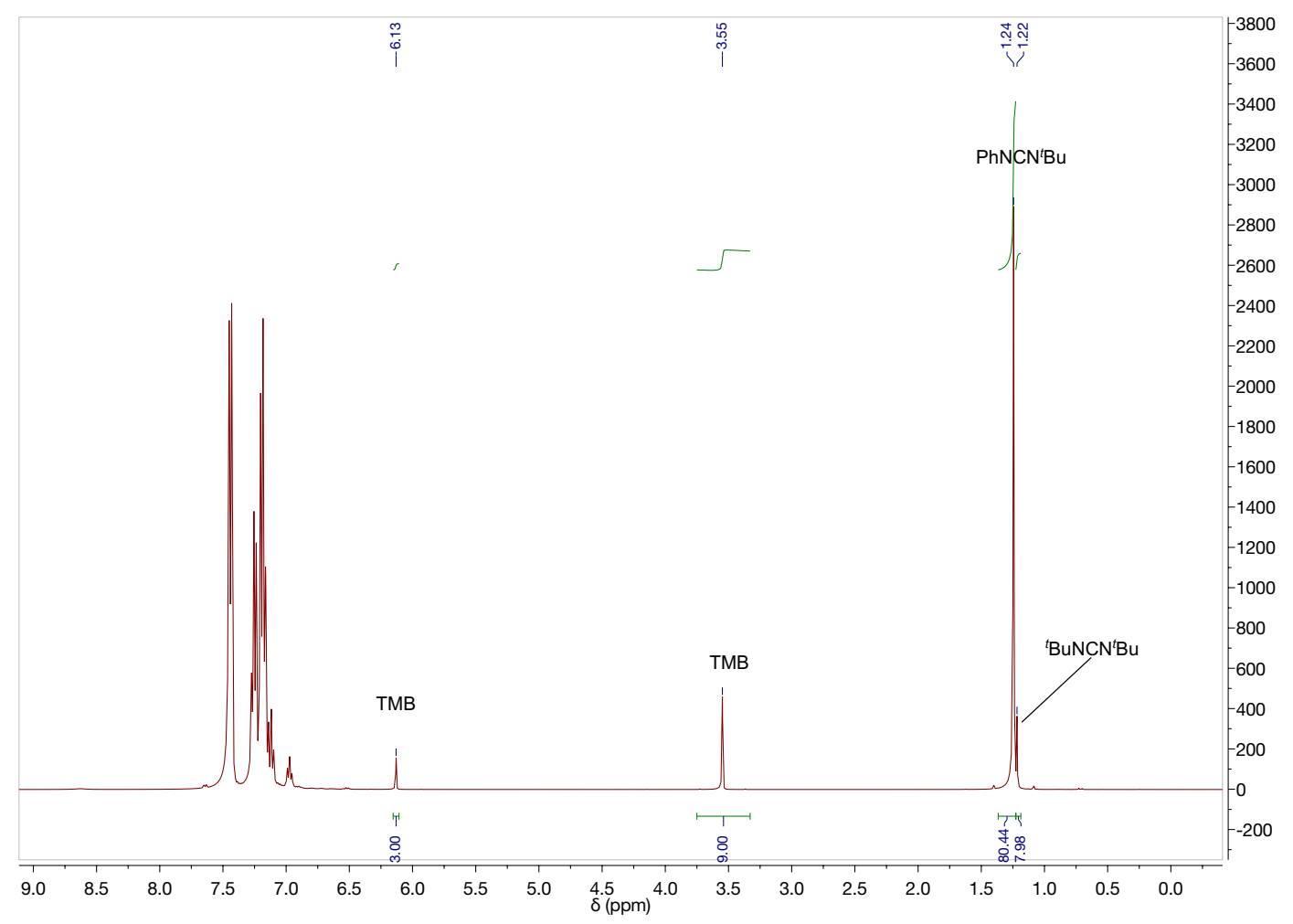

Figure S62. ${ }^{1} \mathrm{H}$ NMR spectrum of the reaction of 1-tert-butyl-3-phenylcarbodiimide catalyzed by $\mathbf{1 b}$ at $\mathrm{t}=24 \mathrm{~h}$ in $\mathrm{PhCF}_{3}$ showing the formation of 1,3-di-tertbutylcarbodiimide. 


\section{Same Excess Experiment and Discussion:}

All three experiments performed in the same excess analysis had NMR spectra collected with a delay time $=10$, acquisition time $=5$, and number of scans $=2$. Spectra were collected every 5 minutes for 1 hour, then every 10 minutes for the next 1 hour and 10 minutes.

Two stock solutions were generated for performing the same excess experiments. The first stock solution $(\mathrm{A})$ included azobenzene $(0.823 \mathrm{M})$ and tert-butylisocyanide $(2.47 \mathrm{M})$ in $\mathrm{C}_{6} \mathrm{D}_{5} \mathrm{Br}$. The second stock solution (B) included $\left[\mathrm{py}_{2} \operatorname{TiBr}_{2}\left(\mathrm{~N}^{t} \mathrm{Bu}\right)\right]_{2}(0.0414 \mathrm{M}, 0.0828 \mathrm{M}$ in $\mathrm{Ti})$ and 1,3,5-trimethoxybenzene $(0.0951 \mathrm{M})$ as an internal standard in $\mathrm{C}_{6} \mathrm{D}_{5} \mathrm{Br}$.

The first reaction (0.32 $\mathrm{M}$ [Azo], blue diamonds) was prepared in an NMR tube in an $\mathrm{N}_{2}$ glovebox using $0.20 \mathrm{~mL}$ of $\mathrm{A}, 0.20 \mathrm{~mL}$ of $\mathrm{B}$, and diluted with an additional $0.10 \mathrm{~mL}$ of $\mathrm{C}_{6} \mathrm{D}_{5} \mathrm{Br}$, then sealed, wrapped with electric tape and parafilm. The second reaction $(0.16$ $\mathrm{M}$ [Azo], orange squares) was prepared in an NMR tube in an $\mathrm{N}_{2}$ glovebox using $0.10 \mathrm{~mL}$ of $\mathrm{A}, 0.20 \mathrm{~mL}$ of $\mathrm{B}$, and diluted with an additional $0.20 \mathrm{~mL}$ of $\mathrm{C}_{6} \mathrm{D}_{5} \mathrm{Br}$, then sealed, wrapped with electric tape and parafilm. The "Time Adjusted" plot (green triangles) was made by adjusting the time of the reaction profile of the $0.16 \mathrm{M}$ [Azo] plot to the time in which the $0.32 \mathrm{M}$ [Azo] reaction had reached approximately $0.16 \mathrm{M}$ in azobenzene concentration. The lack of overlay in the "Time Adjusted" plot (green triangles) with the $0.32 \mathrm{M}$ [Azo] plot (blue diamonds) indicates that this catalytic system is not robust, either through catalyst decomposition after several turnovers and/or product inhibition. 


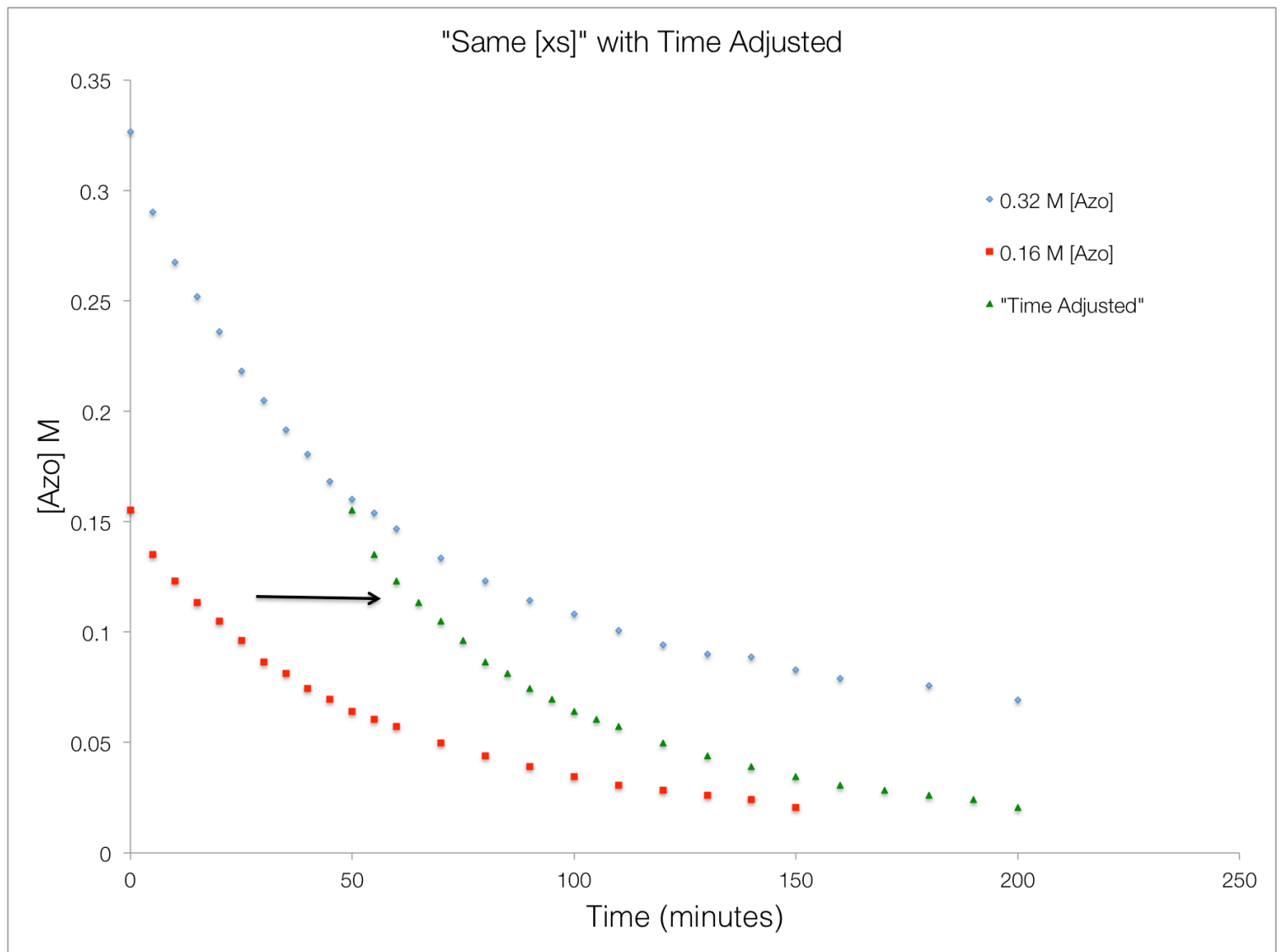

Figure S63. Same excess plot showing a lack of overlay with "Time Adjusted."

Given the above indication that this catalytic system was not robust, a third experiment was run in order to indicate if catalyst decomposition and/or product inhibition was occurring. This third experiment (0.16 M [Azo] with $0.16 \mathrm{M}$ [PhNCNtBu] "Time Adjusted," orange triangles) was prepared in an NMR tube in an $\mathrm{N}_{2}$ glovebox using $0.10 \mathrm{~mL}$ of $\mathrm{A}, 0.20 \mathrm{~mL}$ of $\mathrm{B}$, diluted with an additional $0.20 \mathrm{~mL}$ of $\mathrm{C}_{6} \mathrm{D}_{5} \mathrm{Br}$, and $0.16 \mathrm{mmol} \mathrm{1-tert-butyl-3-}$ phenylcarbodiimide which contained $0.0060 \mathrm{mmol}$ 1,3-di-tert-butylcarbodiimide was added. The tube was then sealed, wrapped with electric tape and parafilm. Once again, the time of the reaction profile was adjusted to the time in which the $0.32 \mathrm{M}$ [Azo] reaction had reached approximately $0.16 \mathrm{M}$ in azobenzene concentration. An overlay of the reaction profiles for the $0.32 \mathrm{M}$ [Azo] reaction (blue diamonds) with the $0.16 \mathrm{M}$ [Azo] with $0.16 \mathrm{M}$ [PhNCNtBu] "Time Adjusted" reaction (orange triangles) would indicate that 1-tert-butyl3-phenylcarbodiimide plays an inhibitive role in catalysis. A lack of overlay in these two plots indicates that some extent of catalyst decomposition is occurring. Alternatively, overlay of the reaction profiles for $0.16 \mathrm{M}$ [Azo] "Time Adjusted" (green squares) and the $0.16 \mathrm{M}$ [Azo] with $0.16 \mathrm{M}$ [PhNCNtBu] "Time Adjusted" reaction (orange triangles) would indicate that the catalyst decomposes after several turnovers. A lack of overlay in these two plots indicates that some extent of product inhibition by 1-tert-butyl-3-phenyl carbodiimide occurs. Given the lack of overlay in any of the reaction profiles, our current conclusion is that catalyst decomposition and product inhibition by 1-tert-butyl-3-phenyl carbodiimide both occur. 


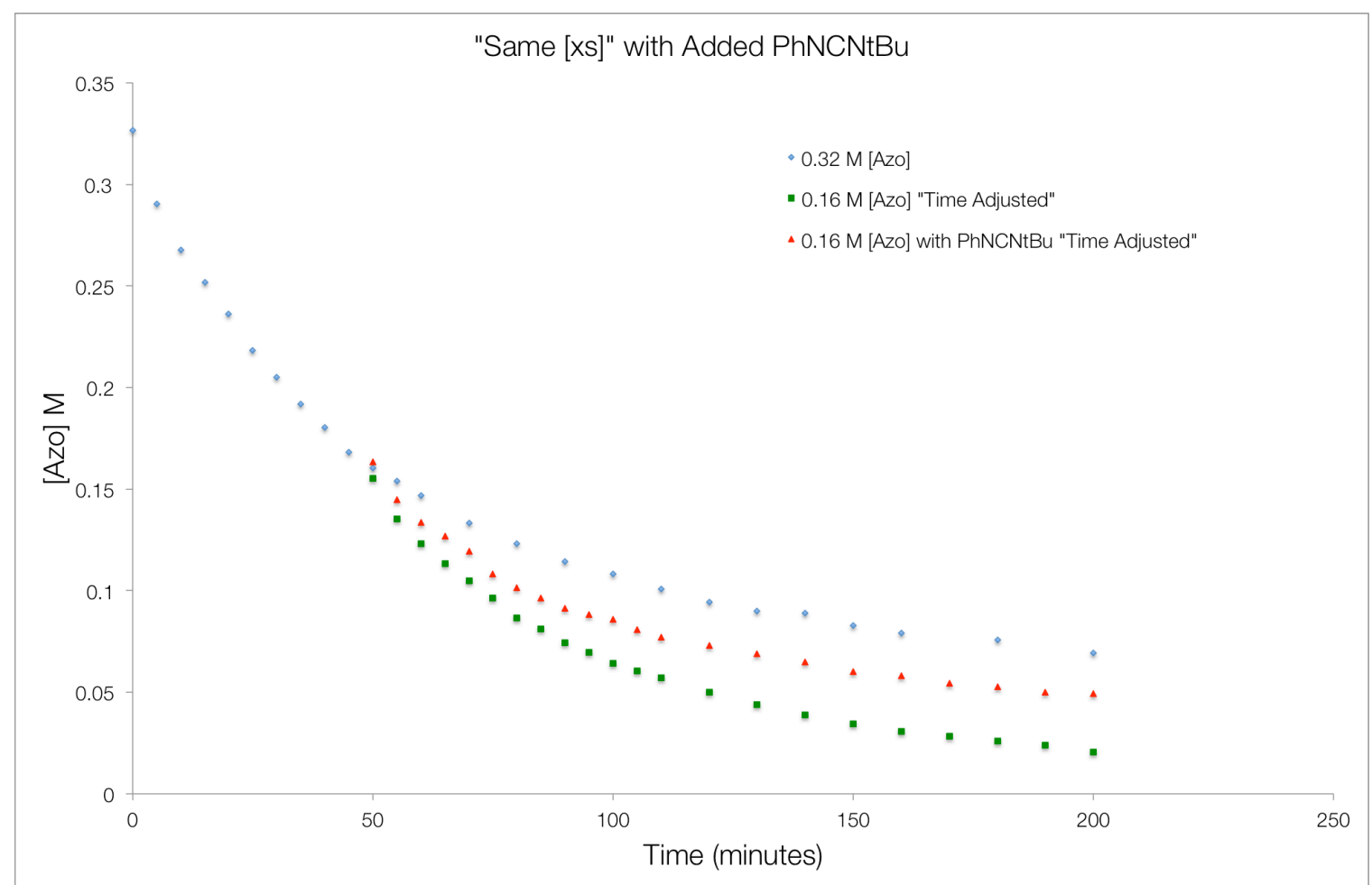

Figure S64. Same excess plot with added 1-tert-butyl-3-phenylcarbodiimide product suggesting product inhibition and catalyst decomposition both playing a role during catalysis. 


\section{Carbodiimide Additives Test on the Catalytic Formation of 1-tert-butyl-3- phenylcarbodiimide:}

All three experiments performed in the carbodiimide additives test had NMR spectra collected with a delay time $=10$, acquisition time $=5$, and number of scans $=2$. Spectra were collected after 30 minutes, 1 h, 2 h, 3 h, 4 h, 6 h, and 8 h.

For carbodiimide additive reactions, $0.5 \mathrm{~mL}$ of a stock solution of $\mathrm{C}_{6} \mathrm{D}_{5} \mathrm{Br}$ containing $0.0167 \mathrm{M}\left[\mathrm{py}_{2} \mathrm{TiBr}_{2}\left(\mathrm{~N}^{t} \mathrm{Bu}\right)\right]_{2}(7.30 \mathrm{mg}, 0.00835 \mathrm{mmol}, 0.334 \mathrm{M}$ in Ti), $0.993 \mathrm{M}$ tert-butyl isocyanide (41.3 $\mathrm{mg}, 0.497 \mathrm{mmol}), 0.332 \mathrm{M}$ azobenzene $(30.3 \mathrm{mg}, 0.166 \mathrm{mmol}$ ) and $0.0309 \mathrm{M} 1,3,5-(\mathrm{OMe})_{3} \mathrm{C}_{6} \mathrm{H}_{3}(2.60 \mathrm{mg}, 0.0155 \mathrm{mmol})$ as an internal standard was prepared and used for NMR tube reactions related to the carbodiimide additives reactions. In an $\mathrm{N}_{2}$ glovebox, the requisite carbodiimide (approximately $10 \mathrm{~mol} \%$ with respect to azobenzene loading) was added to an NMR tube and was dissolved with $0.5 \mathrm{~mL}$ of the stock solution used for the additive reactions.

Additive carbodiimides included 1-(2,6-xylyl)-3-phenylcarbodiimide (4.20 mg, 0.0189 $\mathrm{mmol}$ ) and 1-cyclohexyl-3-phenylcarbodiimide $(4.20 \mathrm{mg}, 0.0210 \mathrm{mmol})$.

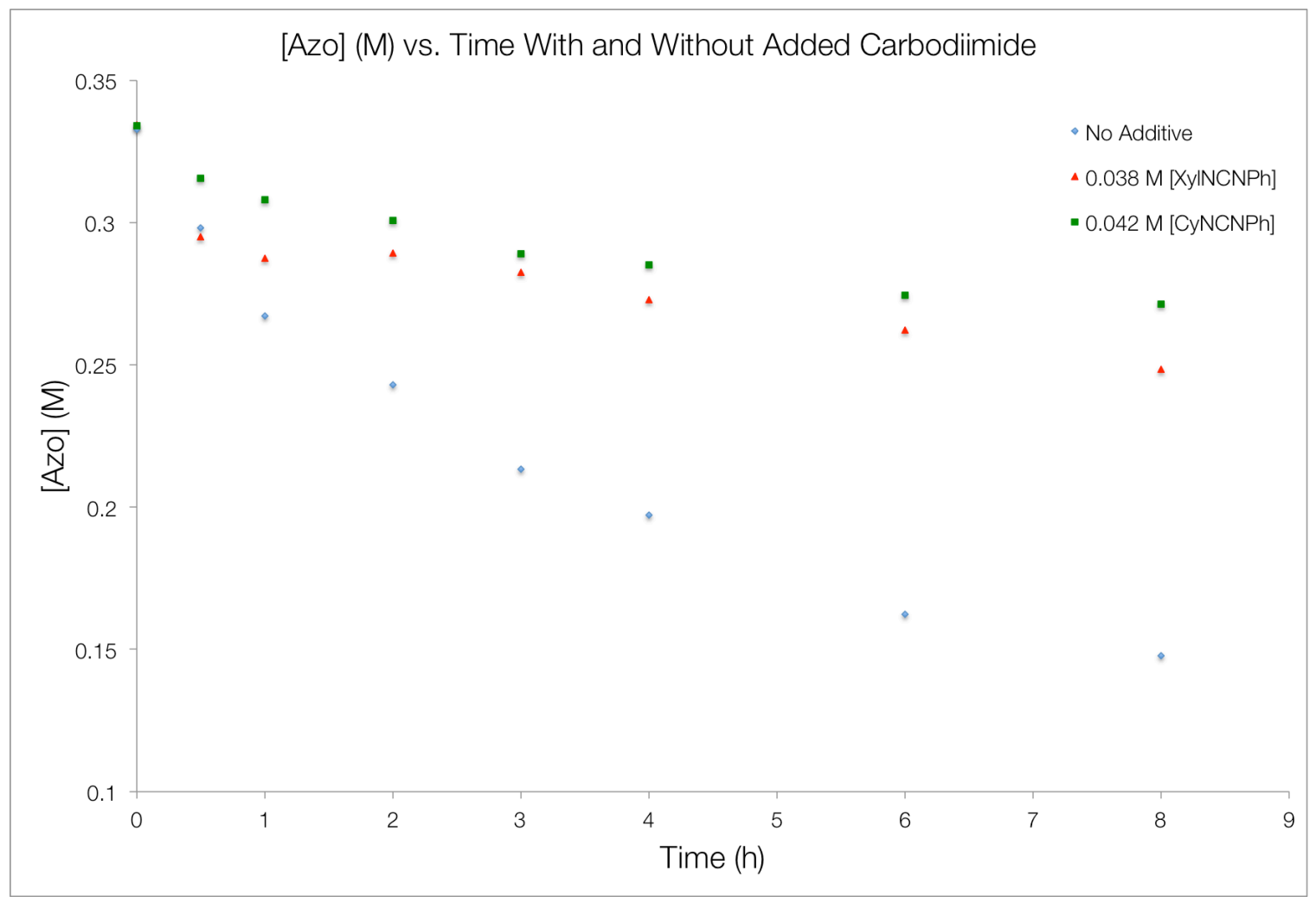

Figure S65. Catalytic formation of 1-tert-butyl-3-phenylcarbodiimide in the presence of substoichiometric quantities of 1-(2,6-xylyl)-3-phenylcarbodiimide and 1-cyclohexyl-3phenylcarbodiimide demonstrating the sluggish consumption of azobenzene in the presence carbodiimides not containing a tert-butyl substituent. 
NMR Spectra for Ti complexes 1b and 1d, and Single Crystal XRD Information for 1d:

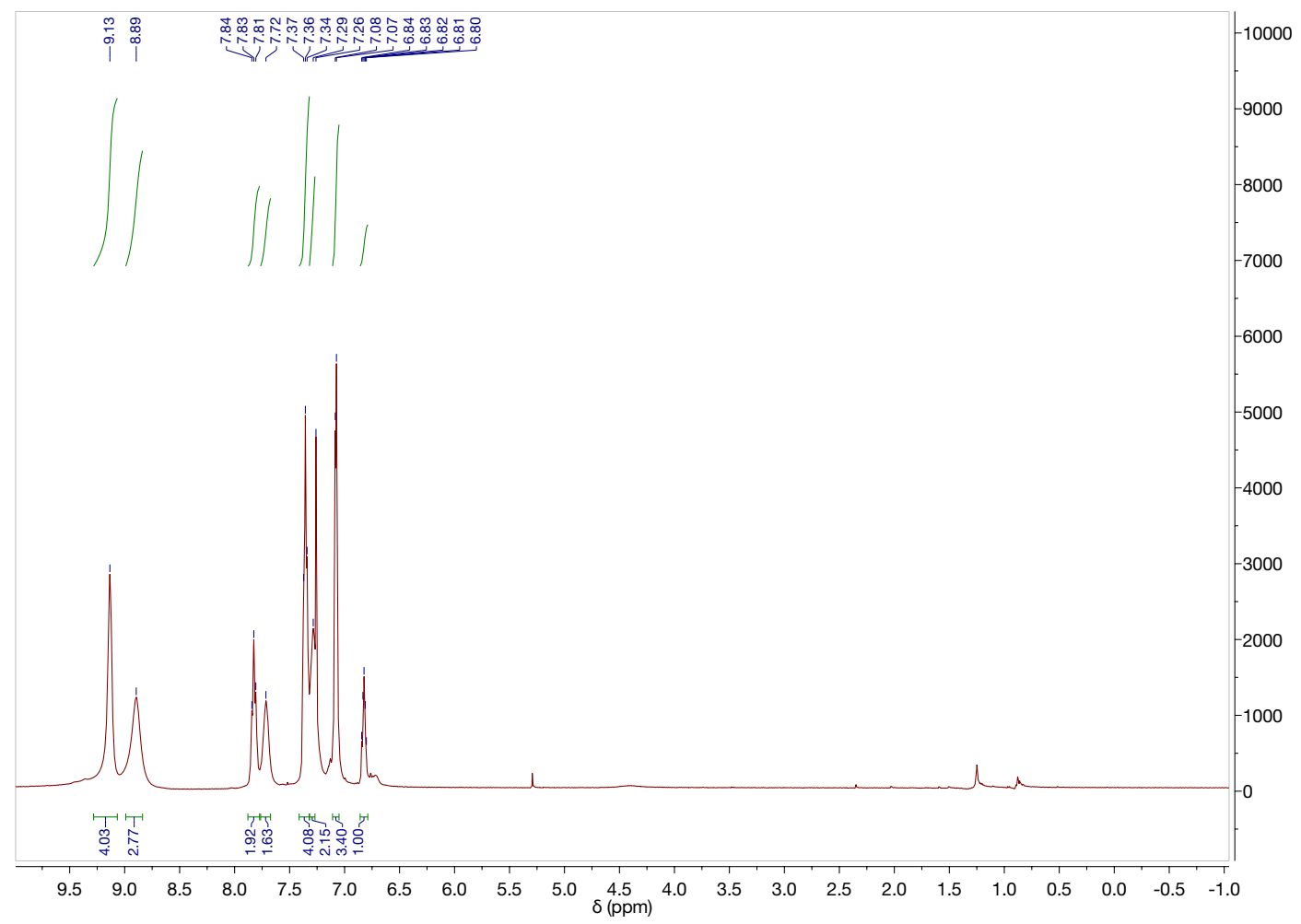

Figure S66. ${ }^{1} \mathrm{H}$ NMR of $\mathrm{Br}_{2} \mathrm{Ti}(\mathrm{NPh}) \mathrm{py}_{3}(\mathbf{1 b})$ in $\mathrm{CDCl}_{3}$. 


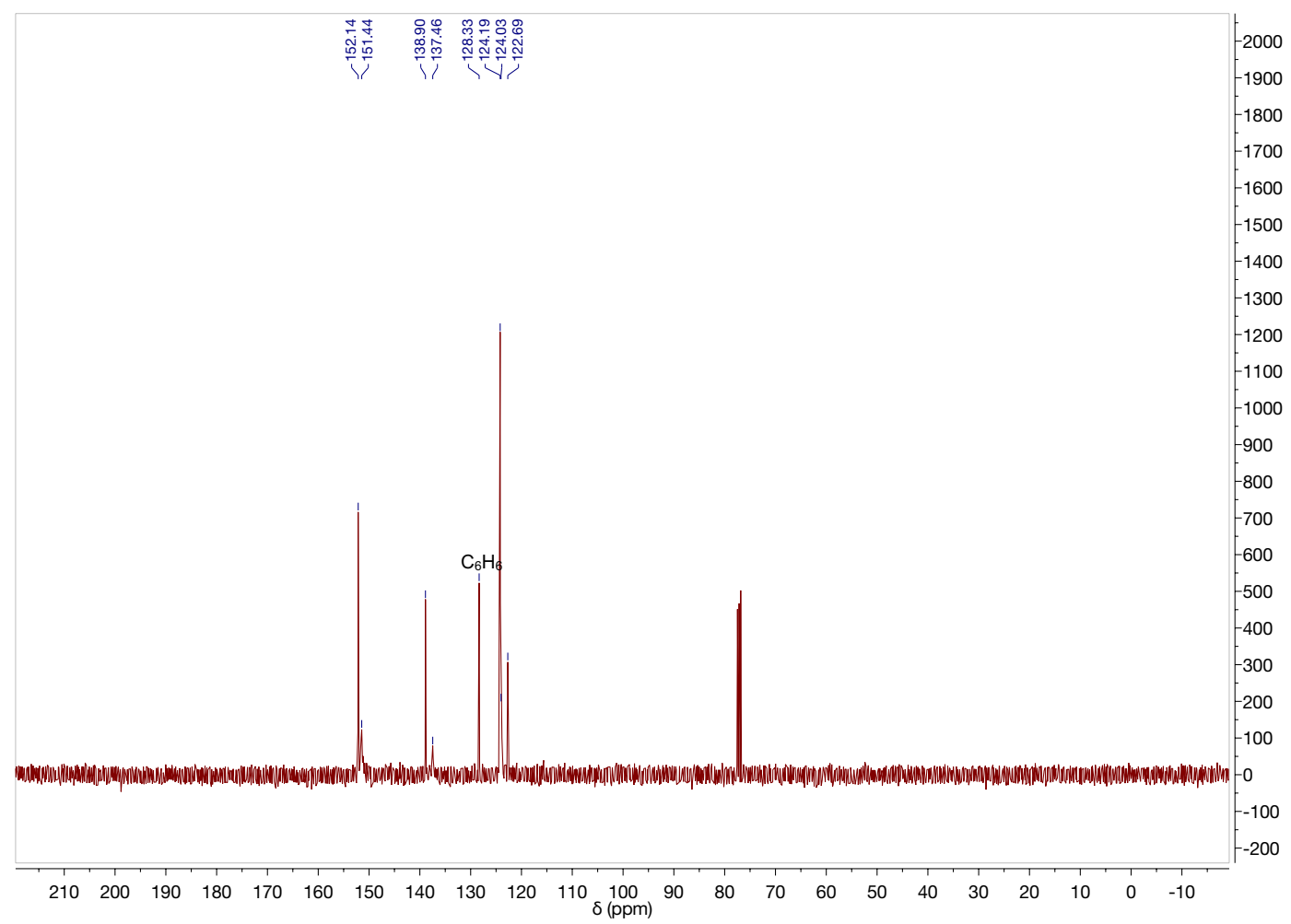

Figure S67. ${ }^{13} \mathrm{C}$ NMR of $\mathrm{Br}_{2} \mathrm{Ti}(\mathrm{NPh}) \mathrm{py}_{3}(\mathbf{1 b})$ in $\mathrm{CDCl}_{3}$. 


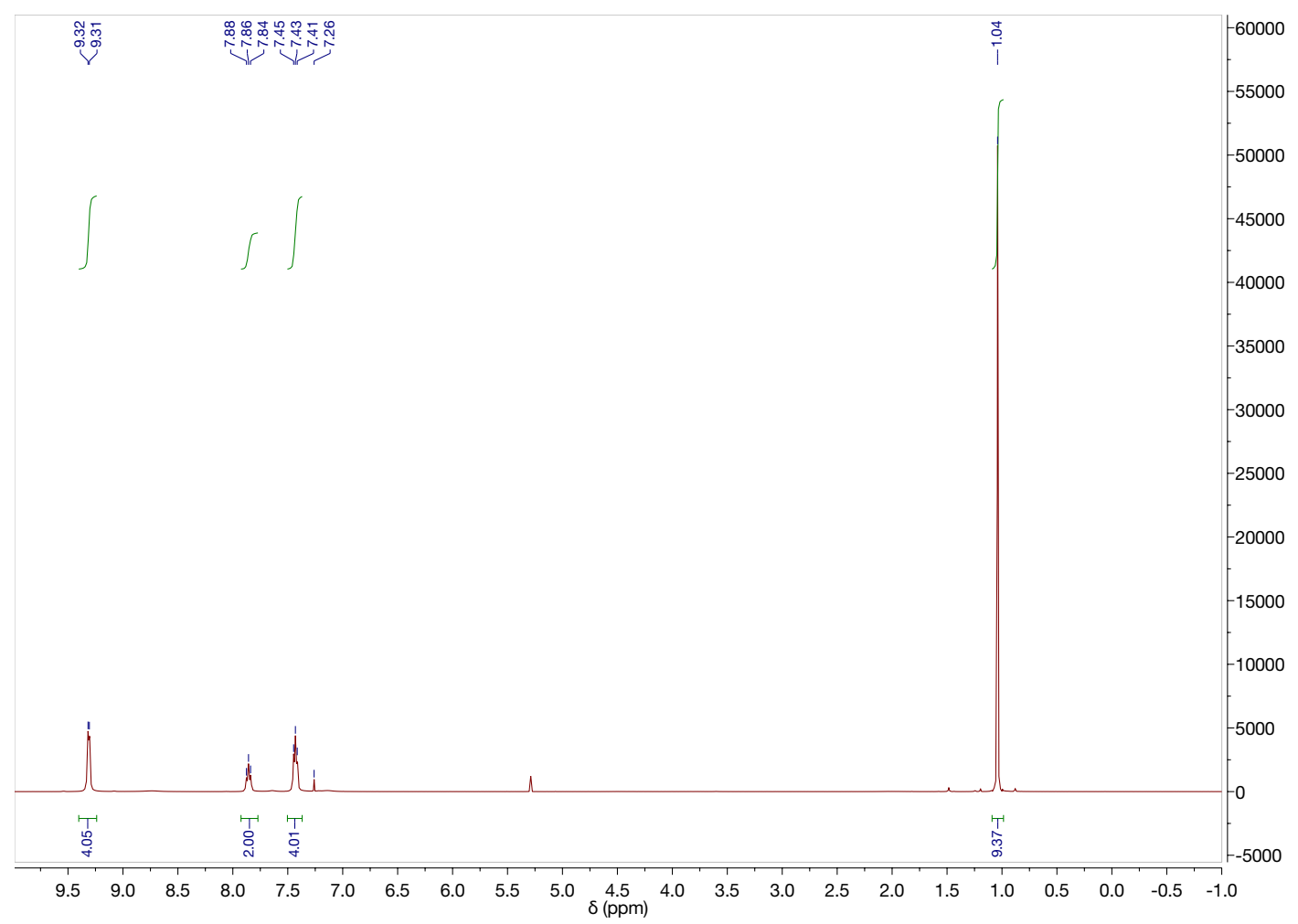

Figure S68. ${ }^{1} \mathrm{H} \mathrm{NMR}$ of $\left[\mathrm{py}_{2} \mathrm{TiBr}_{2}\left(\mathrm{~N}^{t} \mathrm{Bu}\right)\right]_{2}(\mathbf{1 d})$ in $\mathrm{CDCl}_{3}$.

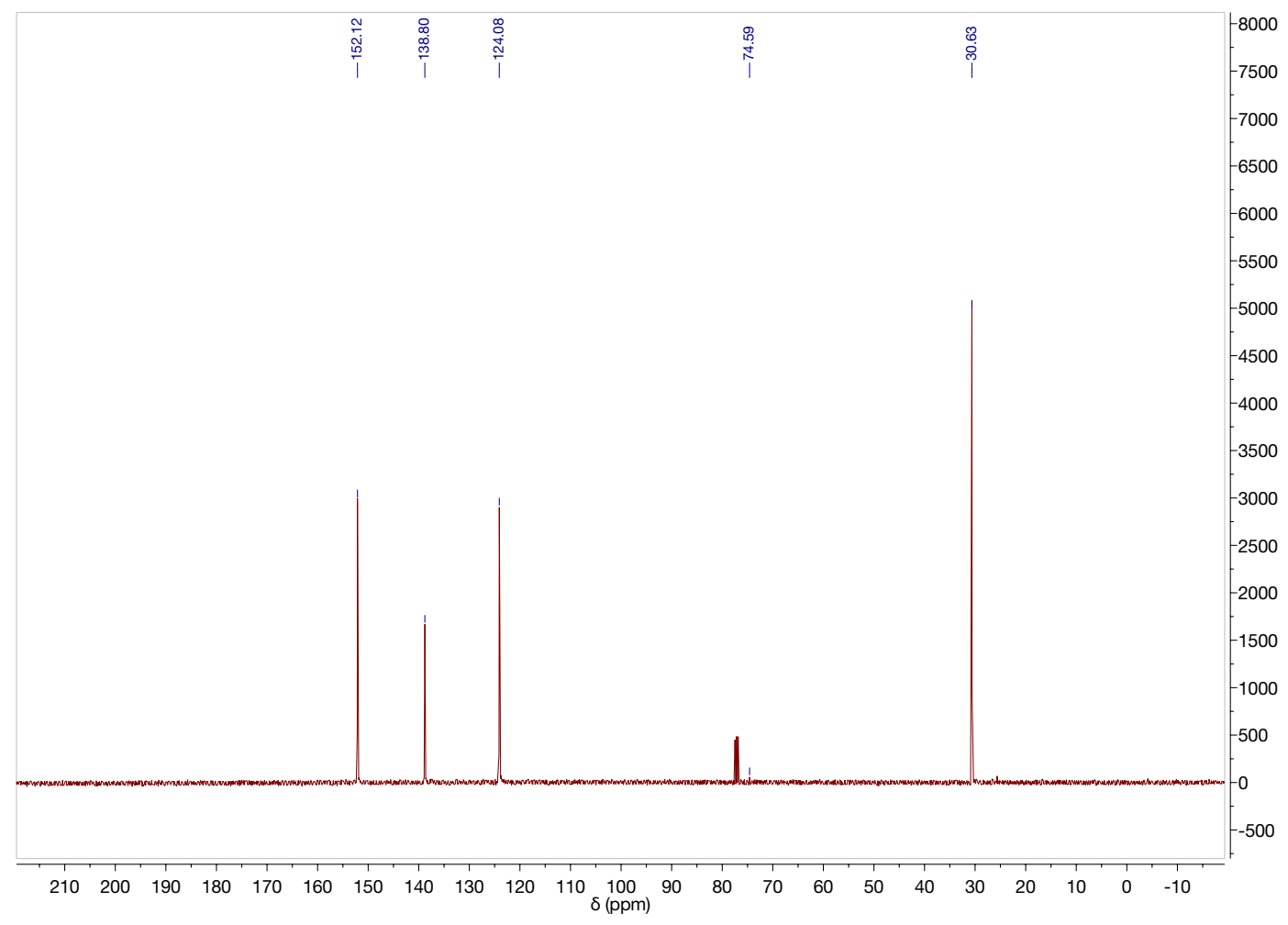

Figure S69. ${ }^{13} \mathrm{C}$ NMR of $\left[\mathrm{py}_{2} \mathrm{TiBr}_{2}\left(\mathrm{~N}^{t} \mathrm{Bu}\right)\right]_{2}(\mathbf{1 d})$ in $\mathrm{CDCl}_{3}$. 

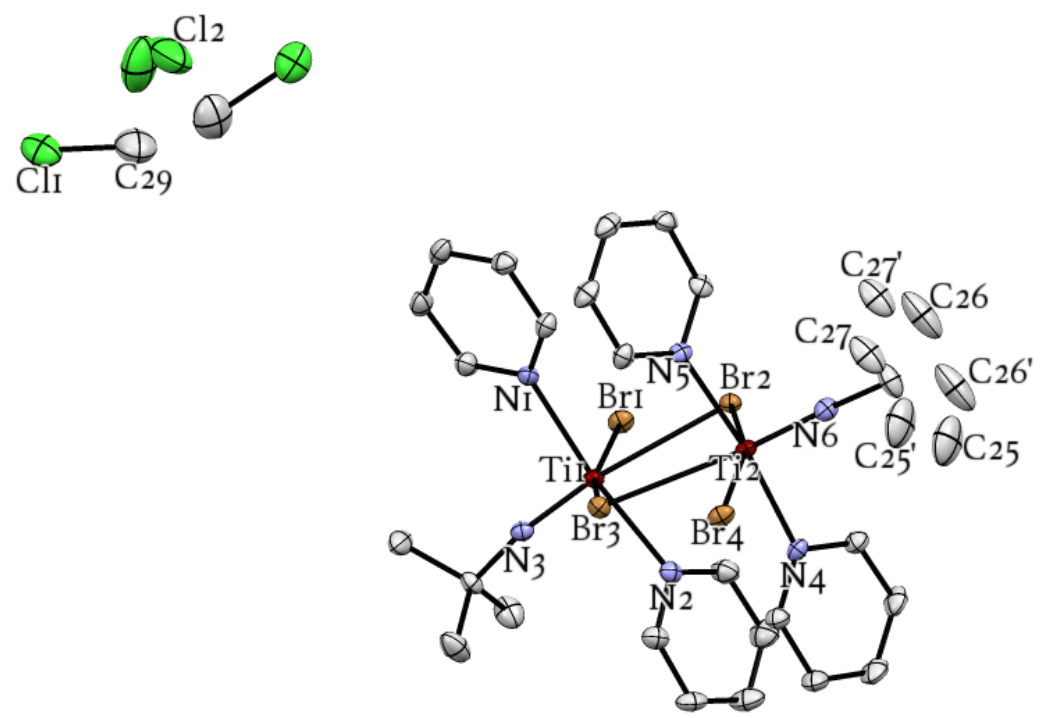

Figure S70. 50\% Thermal ellipsoid drawing of 1d. Hydrogen atoms are omitted for clarity. Tertiary-butyl carbons C25, C26, and C27 (C25', C26', C27') were rotationally disordered and therefore divided into two parts. The occupancy was refined freely (87.3/12.7). Half of a $\mathrm{CH}_{2} \mathrm{Cl}_{2}$ solvent molecule found in the asymmetric unit was disordered near a crystallographic two-fold axis, therefore atoms $\mathrm{C} 29, \mathrm{Cl1}$ and $\mathrm{Cl} 2$ were modeled with DFIX and DANG commands and refined to half occupancy. 
Table S5. Refined data and cell parameters for structures $1 \mathbf{d}$.

\begin{tabular}{|c|c|}
\hline & 1d \\
\hline CCDC Number & 1923119 \\
\hline Empirical Formula & $\mathrm{C}_{28.5} \mathrm{H}_{39} \mathrm{Br}_{4} \mathrm{ClN}_{6} \mathrm{Ti}_{2}$ \\
\hline Formula Weight & 916.54 \\
\hline Temparature (K) & $100(2)$ \\
\hline$a, \AA$ & $24.481(2)$ \\
\hline$b, \AA$ & $9.2829(7)$ \\
\hline$c, \AA$ & $32.174(3)$ \\
\hline$\alpha,{ }^{\circ}$ & 90 \\
\hline$\beta, \AA$ & 103.789(3) \\
\hline$\gamma,{ }^{\circ}$ & 90 \\
\hline Volume, $\AA^{3}$ & $7101.0(10)$ \\
\hline $\mathrm{Z}$ & 8 \\
\hline Crystal System & Monoclinic \\
\hline Space Group & $\mathrm{C} 2 / \mathrm{c}$ \\
\hline $\mathrm{d}_{\text {calc, }}, \mathrm{g} / \mathrm{cm}^{3}$ & 1.715 \\
\hline$\theta$ Range, ${ }^{\circ}$ & 2.355 to 28.280 \\
\hline$\mu, \mathrm{mm}^{-1}$ & 5.055 \\
\hline Abs. Correction & Multi-scan \\
\hline GOF & 1.033 \\
\hline$R_{l}^{a}$ & $R_{1}=0.0454$ \\
\hline $\mathrm{wR}_{2}^{b}[\mathrm{I}>2 \sigma(\mathrm{I})]$ & $w R_{2}=0.0875$ \\
\hline
\end{tabular}




\section{Computational Protocol}

All geometry optimization and frequency calculations were performed using the Gaussian 09 program version e01. All geometries were optimized using M06/6-311 g(d,p) with SMD solvation model indicative of a trifluorotoluene solvent $(\varepsilon=9.18)$ with thermal corrections at $388.15 \mathrm{~K}$ and 1 atm to match experiment. Frequency calculations were performed after geometry optimization to verify the optimized geometries were either at a minimum via the lack of an imaginary frequency for the intermediates or at a transition state with the presence of one imaginary frequency, as well as to obtain the Gibbs free energy. All non-imaginary frequencies smaller than $50 \mathrm{~cm}^{-1}$ were shifted to $50 \mathrm{~cm}-1$ for the thermal energy calculation to correct the fictitious large contribution caused by small frequencies due to the harmonic oscillator approximation. The free energies before and after the frequency calculation are shown with the corresponding geometries with the corrected frequencies reported in parentheses.

As in the previous paper, we used the "superfine" grid in conjunction with the Minnesota functional since these functionals are sensitive to the numeric integration grid. Additionally, the SMD solvent input for trifluorortoluene is the same as the previous work, as shown in the SI, with a change in the temperature setting from the previously used $383.15 \mathrm{~K}$ to $388.15 \mathrm{~K}^{5}$

\section{Natural Bond Orbital Anaylsis}

The Natural Bond Orbital analysis calculates the occupation numbers for the $3 \mathrm{~d}$ orbitals of various compounds. The $3 \mathrm{~d}_{\mathrm{z}^{2}}$ occupation numbers are presented in Table 5; occupation numbers of all 3d orbitals are shown in Table S6. Determination of the formal oxidation date is determined by a comparison of the calculated occupation numbers for our system with calculated occupation numbers for known $\mathrm{Ti}$ oxidation states, as shown in

previous work. ${ }^{5}$ The orbital occupations for $\mathrm{d}_{\mathrm{xy}}, \mathrm{d}_{\mathrm{xz}}, \mathrm{d}_{\mathrm{yz}}$, and $\mathrm{d}_{\mathrm{x}^{2}-\mathrm{y}^{2}}$ remain more consistent than the $\mathrm{d}_{\mathrm{z}^{2}}$ orbital, therefore it is a reasonable assumption that the $3 \mathrm{~d}_{\mathrm{z}^{2}}$ occupation number is more correlated with the formal oxidation state. 
Table S6: The occupation numbers for the $3 \mathrm{~d}$ orbitals from the NBO Analysis for the carbodiimide formation pathway for all six ligand combinations tested. All complexes tested have a singlet multiplicity.

\begin{tabular}{|c|c|c|c|c|c|c|c|}
\hline \multirow{2}{*}{ Ligands } & \multirow[b]{2}{*}{ Complex } & \multicolumn{5}{|c|}{ Occupation Numbers (3d orbitals) } & \multirow[b]{2}{*}{ Formal Oxidation State } \\
\hline & & xy & $\mathrm{xz}$ & $\mathrm{yz}$ & $x^{2}-y^{2}$ & $\mathrm{z}^{2}$ & \\
\hline \multirow[t]{6}{*}{ pyridine/pyridine } & IM0 & 0.09 & 0.16 & 0.27 & 0.28 & 0.31 & +4 \\
\hline & IM1 & 0.07 & 0.24 & 0.26 & 0.27 & 0.31 & +4 \\
\hline & TS1 & 0.08 & 0.15 & 0.24 & 0.30 & 0.35 & +4 \\
\hline & IM2 & 0.11 & 0.12 & 0.17 & 0.28 & 0.44 & +4 \\
\hline & TS2 & 0.07 & 0.10 & 0.15 & 0.21 & 0.65 & +2 \\
\hline & IM3 & 0.06 & 0.14 & 0.17 & 0.17 & 0.63 & +2 \\
\hline \multirow[t]{6}{*}{ pyridine/isocyanide } & IM0 & 0.09 & 0.23 & 0.26 & 0.29 & 0.30 & +4 \\
\hline & IM1 & 0.07 & 0.24 & 0.27 & 0.27 & 0.32 & +4 \\
\hline & TS1 & 0.09 & 0.18 & 0.24 & 0.31 & 0.36 & +4 \\
\hline & IM2 & 0.10 & 0.15 & 0.17 & 0.30 & 0.46 & +4 \\
\hline & TS2 & 0.08 & 0.11 & 0.21 & 0.24 & 0.56 & $+2 /+4$ \\
\hline & IM3 & 0.07 & 0.15 & 0.15 & 0.23 & 0.62 & +2 \\
\hline \multirow[t]{6}{*}{ isocyanide/isocyanide } & IM0 & 0.10 & 0.24 & 0.27 & 0.29 & 0.31 & +4 \\
\hline & IM1 & 0.07 & 0.26 & 0.27 & 0.28 & 0.32 & +4 \\
\hline & TS1 & 0.09 & 0.20 & 0.25 & 0.31 & 0.37 & +4 \\
\hline & IM2 & 0.11 & 0.17 & 0.17 & 0.30 & 0.47 & +4 \\
\hline & TS2 & 0.09 & 0.11 & 0.22 & 0.27 & 0.57 & $+2 /+4$ \\
\hline & IM3 & 0.08 & 0.15 & 0.19 & 0.23 & 0.62 & +2 \\
\hline \multirow[t]{6}{*}{ pyridine } & IM0 & 0.12 & 0.15 & 0.26 & 0.31 & 0.32 & +4 \\
\hline & IM1 & 0.07 & 0.24 & 0.25 & 0.29 & 0.31 & +4 \\
\hline & TS1 & 0.10 & 0.15 & 0.25 & 0.29 & 0.36 & +4 \\
\hline & IM2 & 0.11 & 0.15 & 0.22 & 0.24 & 0.45 & +4 \\
\hline & $\mathrm{TS} 2$ & \multicolumn{5}{|c|}{ no optimized geometry } & \\
\hline & IM3 & 0.05 & 0.05 & 0.14 & 0.14 & 0.76 & +2 \\
\hline \multirow[t]{6}{*}{ isocyanide } & IM0 & 0.10 & 0.17 & 0.27 & 0.31 & 0.32 & +4 \\
\hline & IM1 & 0.08 & 0.24 & 0.27 & 0.30 & 0.31 & +4 \\
\hline & TS1 & 0.10 & 0.16 & 0.25 & 0.28 & 0.39 & +4 \\
\hline & IM2 & 0.13 & 0.13 & 0.24 & 0.24 & 0.45 & +4 \\
\hline & TS2 & 0.09 & 0.16 & 0.17 & 0.23 & 0.58 & $+2 /+4$ \\
\hline & IM3 & 0.07 & 0.07 & 0.14 & 0.22 & 0.67 & +2 \\
\hline \multirow[t]{6}{*}{ azobenzene } & IM0 & 0.12 & 0.22 & 0.26 & 0.29 & 0.31 & +4 \\
\hline & IM1 & 0.07 & 0.24 & 0.26 & 0.29 & 0.31 & +4 \\
\hline & TS 1 & 0.16 & 0.18 & 0.25 & 0.28 & 0.35 & +4 \\
\hline & IM2 & 0.10 & 0.20 & 0.21 & 0.26 & 0.44 & +4 \\
\hline & $\mathrm{TS} 2$ & 0.06 & 0.17 & 0.22 & 0.38 & 0.40 & +4 \\
\hline & IM3 & 0.11 & 0.14 & 0.20 & 0.25 & 0.39 & +4 \\
\hline
\end{tabular}

Carbodiimide Formation pathways selected bond lengths for IM1, TS1, IM2 and TS2 for tested ligand combinations

The bond lengths for Ti-N, Ti-C, and $\mathrm{C}-\mathrm{N}$ (where the $\mathrm{C}$ and $\mathrm{N}$ are forming the $\mathrm{C}=\mathrm{N}$ bond in the carbodiimide), were analyzed and presented below in Table S7. In general, as the carbodiimide is formed and released, the Ti-N bond length increases, the C-N bond length decreases, and the $\mathrm{Ti}-\mathrm{C}$ bond shortens then elongates on the release of the carbodiimide. There is one notable deviation in the TS2 bond lengths for the azobenzene ligand catalyst. As shown in the previous NBO analysis, the Ti(IV) does not reduce to Ti(II) upon dissociation of the carbodiimide product, which explains the difference in the TS2 geometry. This geometry has a shorter Ti-C bond length than the other ligand combinations tested, and a longer Ti-N bond. The $\mathrm{C}-\mathrm{N}$ bond length for the azobenzene TS2 is the same as the azobenzene C-N bond length in IM2. 
Table S7: Selected calculated bond lengths (in $\AA$ ) for all ligand combinations studied in the carbodiimide formation pathway for IM1, TS1, IM2, and TS2.

\begin{tabular}{|c|c|c|c|c|}
\hline Ligands & Complex & Ti-N Bond Length $(\AA)$ & Ti-C Bond Length $(\AA)$ & C-N Bond Length $(\AA)$ \\
\hline pyridine/pyridine & IM1 & 1.70 & 2.24 & 2.89 \\
& TS1 & 1.76 & 2.02 & 1.71 \\
& IM2 & 1.90 & 2.10 & 1.34 \\
& TS2 & 2.07 & 2.53 & 1.27 \\
\hline pyridine/isocyanide & IM1 & 1.71 & 2.24 & 2.84 \\
& TS1 & 1.77 & 2.01 & 1.75 \\
& IM2 & 1.90 & 2.53 & 1.33 \\
& TS2 & 2.07 & 2.25 & 2.85 \\
isocyanide/isocyanide & IM1 & 1.71 & 2.01 & 1.75 \\
& TS1 & 1.77 & 2.12 & 1.33 \\
& IM2 & 1.91 & 2.51 & 1.27 \\
\hline pyridine & TS2 & 2.07 & 2.24 & 2.79 \\
& IM1 & 1.69 & 2.01 & 1.7 \\
& TS1 & 1.76 & 2.06 & 1.35 \\
\hline isocyanide & IM2 & 1.88 & 2.24 & 1.64 \\
& IM1 & 1.69 & 2.01 & 1.35 \\
& TS1 & 1.76 & 2.08 & 1.27 \\
\hline azobenzene & IM2 & 1.88 & 2.58 & 2.81 \\
& TS2 & 2.04 & 2.23 & 1.79 \\
& IM1 & 1.68 & 2.02 & 1.34 \\
& TS1 & 1.77 & 2.06 & 1.34 \\
\hline
\end{tabular}

\section{Carbodiimide Formation pathway with tert-butyl imido starting catalyst}

The carbodiimide formation pathway was studied upon starting catalysis with $\operatorname{py}_{2} \mathrm{TiBr}_{2}(\mathrm{NPh})$ and starting catalysis with $\mathrm{py}_{2} \mathrm{TiBr}_{2}\left(\mathrm{~N}^{t} \mathrm{Bu}\right)$ (Figure $\mathrm{S} 71$ ). The calculations for the $\mathrm{py}_{2} \mathrm{TiBr}_{2}\left(\mathrm{~N}^{t} \mathrm{Bu}\right)$ pathway were performed in the same manner as the $\mathrm{py}_{2} \mathrm{TiBr}_{2}(\mathrm{NPh})$ calculations. The py $\operatorname{TiBr}_{2}\left(\mathrm{~N}^{t} \mathrm{Bu}\right)$ catalyst was higher in energy than $\mathrm{py}_{2} \mathrm{TiBr}_{2}(\mathrm{NPh})$ at every step in the reaction path by $3.9-9.4 \mathrm{kcal} / \mathrm{mol}$. The initial insertion of ${ }^{t} \mathrm{Bu}$ isocyanide is much higher in energy for the ${ }^{t} \mathrm{Bu}$ imido catalyst than the $\mathrm{Ph}$ imido catalyst, indicating that it is unlikely for the catalysis to proceed through the ${ }^{t} \mathrm{Bu}$ imido catalyst if the $\mathrm{Ph}$ imido catalyst is available. 


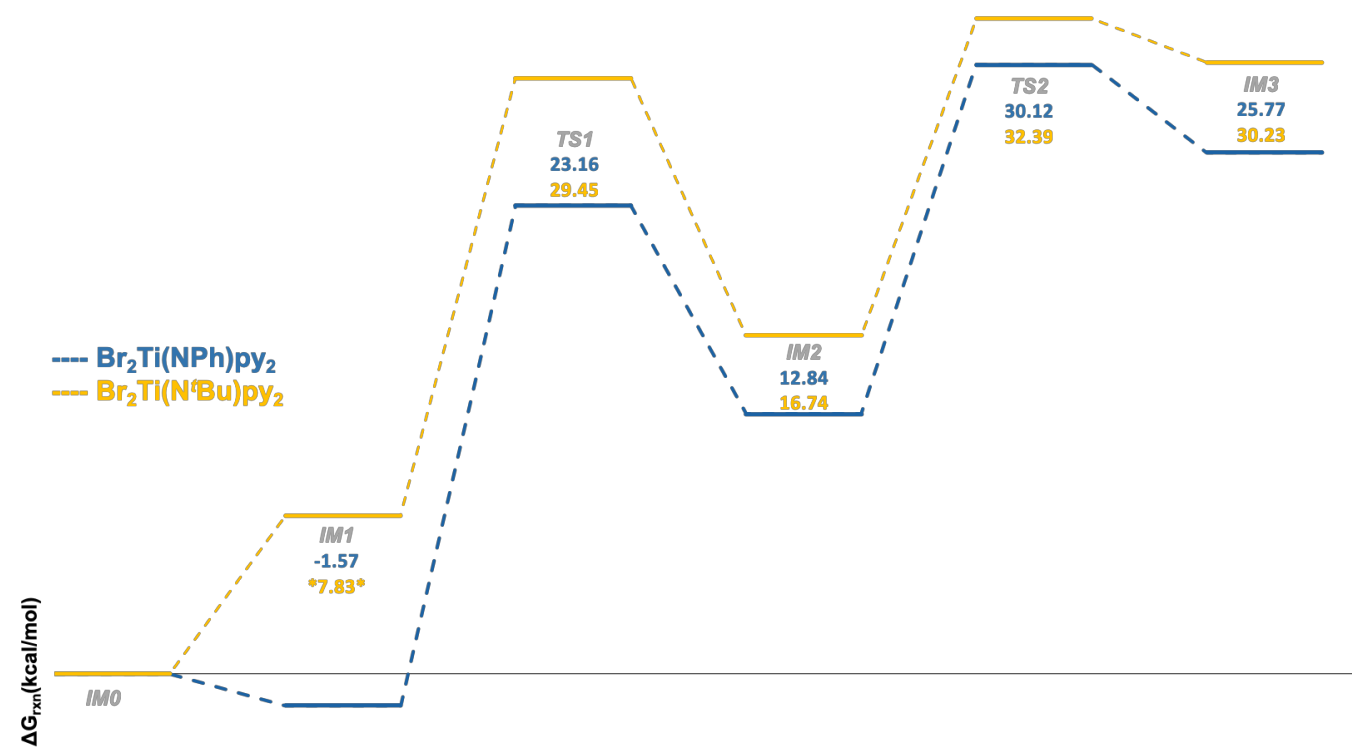

Figure S71: Comparison of phenyl imido catalyst (blue) with tert-butyl imido catalyst (yellow) for carbodiimide formation pathway. The free energies are reported in $\mathrm{kcal} / \mathrm{mol}$, and the individual steps are the same as in Figure 4. *This geometry (yellow IM1) was not fully optimized - included the presence of a small imaginary frequency $\left(-24.7 \mathrm{~cm}^{-1}\right)$ however prior work suggests the energy will not change by more than a couple $\mathrm{kcal} / \mathrm{mol}$. 


\section{Carbodiimide Metathesis pathways for imido and carbodiimide combinations}

We studied possible combinations of the carbodiimide metathesis pathway to determine the lowest energy combination of the starting phenyl imido Ti catalyst reacting with various symmetric and unsymmetric carbodiimides to regenerate either the phenyl imido catalyst or the $t$-butyl imido catalyst. The four pathways studied were:

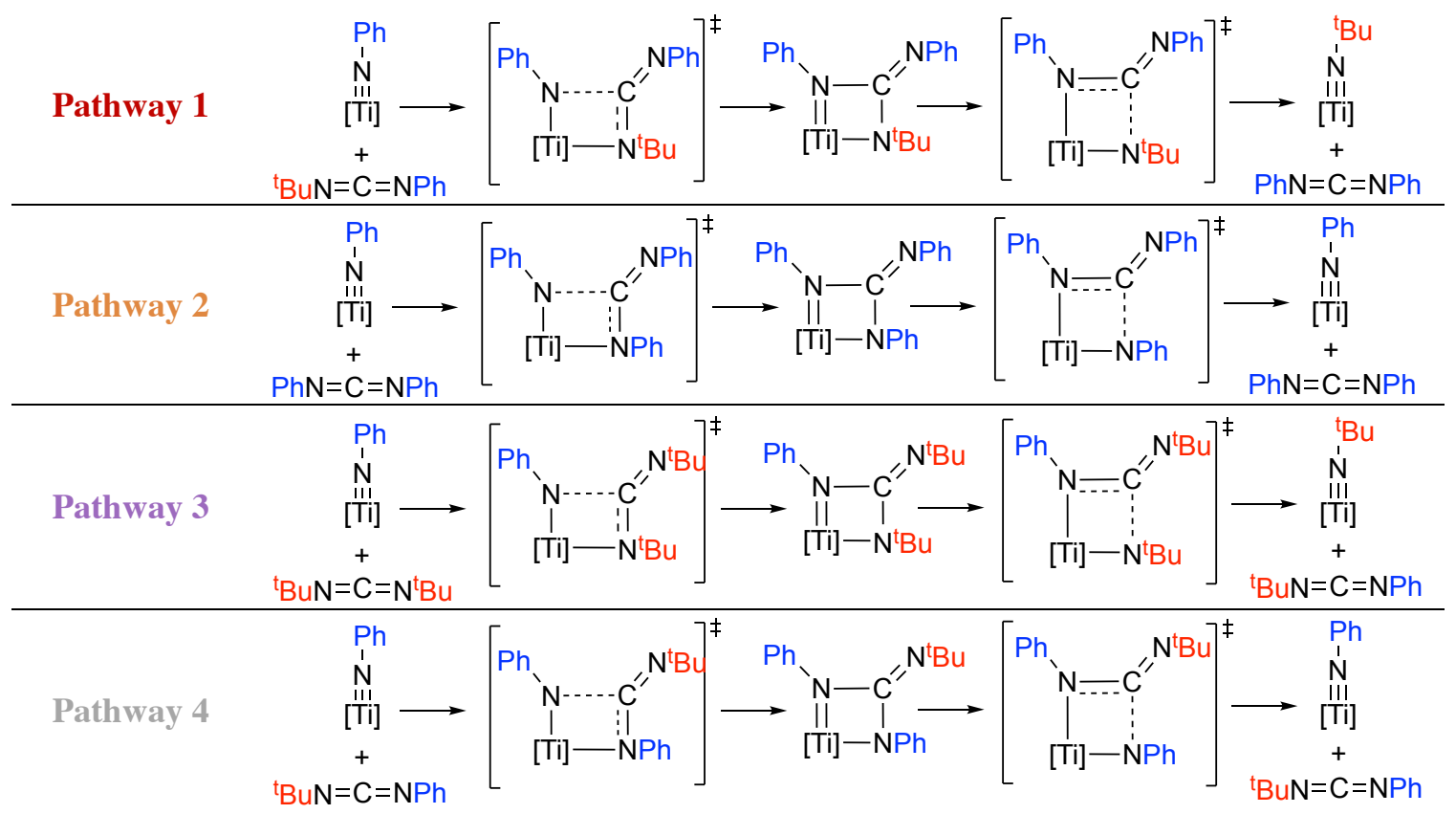

where pathway 1 is the carbodiimide metathesis pathway shown in Figure 7 (red). Pathway 1 is the reaction of the phenyl imido catalyst with the carbodiimide formation pathway carbodiimide product, ${ }^{t} \mathrm{BuNCNPh}$.

Figure S72 shows the mechanism for these 4 pathways. The rate determining step for pathways 1-3 is TS2-CM. Pathway 2 (orange) has the lowest barrier at $23.7 \mathrm{kcal} / \mathrm{mol}$ compared to $34.7 \mathrm{kcal} / \mathrm{mol}$ and $33.5 \mathrm{kcal} / \mathrm{mol}$ for pathways 1 (red) and 3 (purple), respectively. Pathway 4 (grey) is the same carbodiimide reactant as pathway 1 ( ${ }^{t} \mathrm{BuNCNPh}$ ), however the orientation of the two $\mathrm{R}$ groups is swapped. Interestingly, pathway 4 shows that TS1-CM is higher energy than TS2-CM, indicating that this is the rate-determining step at $24.1 \mathrm{kcal} / \mathrm{mol}$. These results show that all of these pathways should be possible under reaction conditions accounting for scrambling. 


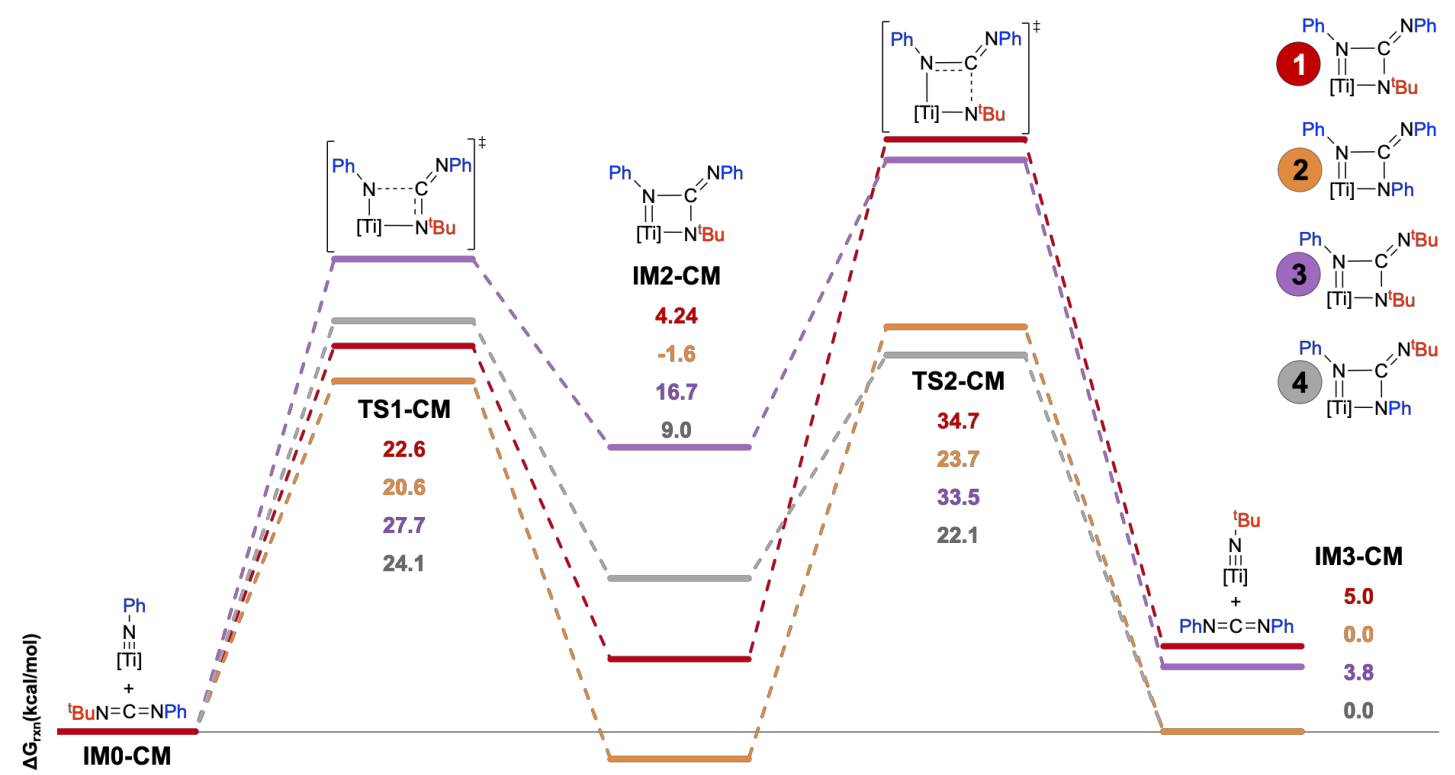

Figure S72. Comparison of carbodiimide metathesis pathways with various combinations of the phenyl imido catalyst with symmetric and unsymmetric carbodiimides. All free energies are reported in $\mathrm{kcal} / \mathrm{mol}$ at $388.15 \mathrm{~K}$ and $1 \mathrm{~atm}$. Pathway 1 (red) is the same carbodiimide metathesis pathway seen in Figure 7. [Ti] $=p_{2} \mathrm{TiBr}_{2}$ for all pathways investigated. 


\section{Isodesmic Reactions}

Calculations for various isodesmic reactions were calculated using the same computational protocol listed above. The free energies of these reactions were calculated using the formula:

$$
\Delta \mathrm{G}=\Sigma \mathrm{G}_{\text {products }}-\Sigma \mathrm{G}_{\text {reactants }}
$$

For most of these reactions, the forward reaction is highly favored.

Table S8: Various isodesmic reaction calculations and free energies (in $\mathrm{kcal} / \mathrm{mol}$ ) calculated using equation 1 above. $[\mathrm{Ti}]=\mathrm{py}_{2} \mathrm{TiBr}_{2}$

(5)




\section{Cartesian Coordinates in $\AA$, Electron Energies and Free Energies before and after (within bracket) elimination of low frequency modes at $388.15 \mathrm{~K}$ at $1 \mathrm{~atm}$ for the optimized structures.}

I. The effects of different ligands during carbodiimide formation (Fig. 3).

\section{$\mathbf{L}=$ pyridine/pyridine (blue)}

IM0 M06/6-311g(d,p)/superfine in PhCF3 Solvent Electronic energy -6780.283704 a.u.

Gibbs free energy -6780.089629 (-6780.087578) a.u. 37

$\begin{array}{lrrr}\mathrm{Ti} & -0.112681 & -0.528258 & 0.055953 \\ \mathrm{~N} & -2.297000 & 0.159125 & -0.393705 \\ \mathrm{~N} & 0.066308 & 1.690964 & 0.016634 \\ \mathrm{~N} & 1.550220 & -0.645895 & -0.231417 \\ \mathrm{C} & 2.899819 & -0.482861 & -0.359631 \\ \mathrm{C} & 3.614771 & -1.056436 & -1.424869 \\ \mathrm{C} & 4.983650 & -0.869982 & -1.533486 \\ \mathrm{C} & 3.606490 & 0.287784 & 0.581740 \\ \mathrm{C} & 4.973744 & 0.469467 & 0.460277 \\ \mathrm{C} & 5.672251 & -0.107125 & -0.595999 \\ \mathrm{H} & 3.073086 & -1.654178 & -2.152761 \\ \mathrm{H} & 5.521225 & -1.325945 & -2.360631 \\ \mathrm{H} & 5.502493 & 1.066859 & 1.198700 \\ \mathrm{H} & 6.744687 & 0.035790 & -0.686769 \\ \mathrm{H} & 3.050243 & 0.730703 & 1.404944 \\ \mathrm{C} & 0.827322 & 2.240771 & -0.940674 \\ \mathrm{C} & -0.572167 & 2.506181 & 0.867299 \\ \mathrm{C} & 0.969520 & 3.608205 & -1.087159 \\ \mathrm{C} & -0.467749 & 3.882584 & 0.799116 \\ \mathrm{C} & 0.313424 & 4.445354 & -0.198752 \\ \mathrm{H} & 1.336694 & 1.550167 & -1.606920 \\ \mathrm{H} & 1.592302 & 4.000612 & -1.882916 \\ \mathrm{H} & 0.411136 & 5.523255 & -0.281694 \\ \mathrm{H} & -0.997511 & 4.497052 & 1.517605 \\ \mathrm{H} & -1.184421 & 2.030442 & 1.628210 \\ \mathrm{C} & -3.327788 & -0.194966 & 0.381149 \\ \mathrm{C} & -4.641288 & 0.084085 & 0.047784 \\ \mathrm{C} & -4.901145 & 0.745657 & -1.142385 \\ \mathrm{C} & -3.836707 & 1.107158 & -1.954883 \\ \mathrm{C} & -2.554482 & 0.798914 & -1.539511 \\ \mathrm{H} & -3.082987 & -0.725330 & 1.298581 \\ \mathrm{H} & -5.442068 & -0.219899 & 0.712122 \\ \mathrm{H} & -5.920844 & 0.974025 & -1.435201 \\ \mathrm{H} & -1.694465 & 1.068997 & -2.150446 \\ \mathrm{H} & -3.992076 & 1.621503 & -2.896319 \\ \mathrm{Br} & -0.293276 & -0.749414 & 2.482166 \\ \mathrm{Br} & -0.936243 & -2.701171 & -0.866114\end{array}$

IM1 M06/6-311g(d,p)/superfine in PhCF3 Solvent Electronic energy -7030.863351 a.u.

Gibbs free energy $-7030.558280(-7030.553853)$ a.u. 52

$\begin{array}{lrrr}\mathrm{Ti} & -0.324331 & -0.098811 & 0.085680 \\ \mathrm{~N} & 0.916080 & -2.168101 & -0.242948 \\ \mathrm{~N} & -2.123289 & -1.408083 & 0.204397 \\ \mathrm{~N} & -1.104913 & 1.405089 & 0.212440 \\ \mathrm{C} & -1.636084 & 2.654282 & 0.108483 \\ \mathrm{C} & -0.954644 & 3.669782 & -0.588462 \\ \mathrm{C} & -1.500282 & 4.937436 & -0.699868 \\ \mathrm{C} & -2.882561 & 2.964195 & 0.682569 \\ \mathrm{C} & -3.419779 & 4.235147 & 0.559628\end{array}$

\begin{tabular}{lrrr} 
& & & \\
$\mathrm{C}$ & -2.734990 & 5.230890 & -0.129169 \\
$\mathrm{H}$ & 0.006406 & 3.431160 & -1.038025 \\
$\mathrm{H}$ & -0.957175 & 5.707798 & -1.241382 \\
$\mathrm{H}$ & -4.384355 & 4.453624 & 1.010635 \\
$\mathrm{H}$ & -3.158890 & 6.226333 & -0.219979 \\
$\mathrm{H}$ & -3.410945 & 2.185776 & 1.227477 \\
$\mathrm{C}$ & -3.232935 & -1.021122 & -0.442513 \\
$\mathrm{C}$ & -2.166315 & -2.542478 & 0.916475 \\
$\mathrm{C}$ & -4.407117 & -1.749051 & -0.407685 \\
$\mathrm{C}$ & -3.300929 & -3.327946 & 0.999938 \\
$\mathrm{C}$ & -4.442849 & -2.925385 & 0.325233 \\
$\mathrm{H}$ & -3.163200 & -0.095689 & -1.006399 \\
$\mathrm{H}$ & -5.275936 & -1.391198 & -0.947807 \\
$\mathrm{H}$ & -5.350260 & -3.518938 & 0.372510 \\
$\mathrm{H}$ & -3.281862 & -4.237397 & 1.589358 \\
$\mathrm{H}$ & -1.256237 & -2.816641 & 1.441971 \\
$\mathrm{C}$ & 2.078054 & -2.394115 & 0.381605 \\
$\mathrm{C}$ & 2.848099 & -3.524332 & 0.166521 \\
$\mathrm{C}$ & 2.390222 & -4.483536 & -0.722619 \\
$\mathrm{C}$ & 1.182848 & -4.266275 & -1.367670 \\
$\mathrm{C}$ & 0.489800 & -3.097083 & -1.107185 \\
$\mathrm{H}$ & 2.397386 & -1.638767 & 1.095202 \\
$\mathrm{H}$ & 3.786315 & -3.645395 & 0.696676 \\
$\mathrm{H}$ & 2.964928 & -5.385190 & -0.910335 \\
$\mathrm{H}$ & -0.443981 & -2.886845 & -1.621222 \\
$\mathrm{H}$ & 0.779634 & -4.985572 & -2.071787 \\
$\mathrm{C}$ & 1.713409 & 0.816948 & -0.028412 \\
$\mathrm{~N}$ & 2.768877 & 1.291748 & -0.017211 \\
$\mathrm{C}$ & 4.108575 & 1.837009 & 0.084447 \\
$\mathrm{C}$ & 4.056016 & 3.284435 & -0.377847 \\
$\mathrm{H}$ & 3.723579 & 3.348692 & -1.418583 \\
$\mathrm{H}$ & 3.373496 & 3.867790 & 0.247994 \\
$\mathrm{H}$ & 5.057464 & 3.719780 & -0.303448 \\
$\mathrm{C}$ & 5.009692 & 0.996805 & -0.807287 \\
$\mathrm{H}$ & 5.003162 & -0.050896 & -0.488608 \\
$\mathrm{H}$ & 4.684943 & 1.050331 & -1.850903 \\
$\mathrm{H}$ & 6.034015 & 1.376514 & -0.739413 \\
$\mathrm{C}$ & 4.518062 & 1.730454 & 1.546124 \\
$\mathrm{H}$ & 3.839427 & 2.305733 & 2.183560 \\
$\mathrm{H}$ & 4.509798 & 0.686005 & 1.876016 \\
$\mathrm{H}$ & 5.531550 & 2.126718 & 1.664474 \\
$\mathrm{Br}$ & 0.224347 & -0.468538 & 2.547961 \\
$\mathrm{Br}$ & -0.320604 & -0.093200 & -2.464632 \\
& & & \\
\hline
\end{tabular}

TS1 M06/6-311g(d,p)/superfine in PhCF3 Solvent Electronic energy -7030.825905 a.u. Gibbs free energy -7030.518227 (-7030.514441) a.u.

$\begin{array}{lrrr}52 & & & \\ \mathrm{Ti} & -0.326669 & -0.230948 & 0.028368 \\ \mathrm{~N} & -1.770501 & 1.596268 & 0.021952 \\ \mathrm{~N} & -2.081468 & -1.657452 & -0.085148 \\ \mathrm{~N} & 1.305854 & -0.895752 & 0.022866 \\ \mathrm{C} & 2.516205 & -1.552748 & -0.056198 \\ \mathrm{C} & 2.857104 & -2.474970 & 0.938961 \\ \mathrm{C} & 4.051517 & -3.173805 & 0.859857 \\ \mathrm{C} & 3.397275 & -1.332212 & -1.121451 \\ \mathrm{C} & 4.586322 & -2.040528 & -1.191844 \\ \mathrm{C} & 4.920027 & -2.960861 & -0.204444 \\ \mathrm{H} & 2.167836 & -2.629012 & 1.765143 \\ \mathrm{H} & 4.306358 & -3.890204 & 1.635716\end{array}$




$\begin{array}{lrrr}\mathrm{H} & 5.260226 & -1.872904 & -2.027328 \\ \mathrm{H} & 5.854098 & -3.511252 & -0.265073 \\ \mathrm{H} & 3.127494 & -0.617020 & -1.892932 \\ \mathrm{C} & -1.871397 & -2.884934 & 0.408813 \\ \mathrm{C} & -3.254164 & -1.403252 & -0.679173 \\ \mathrm{C} & -2.814914 & -3.892009 & 0.332713 \\ \mathrm{C} & -4.257615 & -2.348148 & -0.779201 \\ \mathrm{C} & -4.034243 & -3.616899 & -0.266148 \\ \mathrm{H} & -0.908153 & -3.061424 & 0.882248 \\ \mathrm{H} & -2.591323 & -4.870581 & 0.741482 \\ \mathrm{H} & -4.799955 & -4.382942 & -0.335919 \\ \mathrm{H} & -5.193372 & -2.089405 & -1.261245 \\ \mathrm{H} & -3.383486 & -0.408223 & -1.094877 \\ \mathrm{C} & -1.523662 & 2.642188 & -0.779469 \\ \mathrm{C} & -2.317488 & 3.773586 & -0.809984 \\ \mathrm{C} & -3.431607 & 3.830415 & 0.012818 \\ \mathrm{C} & -3.701418 & 2.752093 & 0.839740 \\ \mathrm{C} & -2.845421 & 1.665554 & 0.819854 \\ \mathrm{H} & -0.655615 & 2.559495 & -1.426304 \\ \mathrm{H} & -2.060902 & 4.591106 & -1.474098 \\ \mathrm{H} & -4.078551 & 4.701969 & 0.009904 \\ \mathrm{H} & -3.015651 & 0.816160 & 1.474712 \\ \mathrm{H} & -4.559433 & 2.746350 & 1.502387 \\ \mathrm{C} & 1.405488 & 0.808310 & 0.127810 \\ \mathrm{~N} & 2.522898 & 1.295101 & 0.180362 \\ \mathrm{C} & 2.847556 & 2.730772 & 0.239098 \\ \mathrm{C} & 4.136680 & 2.858821 & 1.036134 \\ \mathrm{H} & 3.992982 & 2.500161 & 2.061468 \\ \mathrm{H} & 4.933492 & 2.265830 & 0.574715 \\ \mathrm{H} & 4.457976 & 3.905682 & 1.078026 \\ \mathrm{C} & 1.740413 & 3.539520 & 0.898167 \\ \mathrm{H} & 0.814090 & 3.497867 & 0.315010 \\ \mathrm{H} & 1.529091 & 3.160702 & 1.905082 \\ \mathrm{H} & 2.042953 & 4.589550 & 0.982965 \\ \mathrm{C} & 3.068628 & 3.185654 & -1.197203 \\ \mathrm{H} & 3.842403 & 2.577984 & -1.679854 \\ \mathrm{H} & 2.144828 & 3.090983 & -1.780317 \\ \mathrm{H} & 3.387574 & 4.234103 & -1.217957 \\ \mathrm{Br} & -0.532901 & -0.152852 & -2.486608 \\ \mathrm{Br} & -0.670454 & -0.299449 & 2.525168\end{array}$

IM2 M06/6-311g(d,p)/superfine in PhCF3 Solvent Electronic energy -7030.846491 a.u.

Gibbs free energy -7030.533390 (-7030.530888) a.u.

$\begin{array}{lrrr}52 & & & \\ \mathrm{Ti} & -0.201263 & -0.273810 & 0.040289 \\ \mathrm{~N} & -1.410559 & 1.528065 & -0.134902 \\ \mathrm{~N} & -2.332123 & -1.270689 & 0.187682 \\ \mathrm{~N} & 1.681761 & -0.450543 & -0.080513 \\ \mathrm{C} & 2.775747 & -1.300763 & -0.130290 \\ \mathrm{C} & 2.562306 & -2.682778 & -0.075016 \\ \mathrm{C} & 3.633839 & -3.556925 & -0.124224 \\ \mathrm{C} & 4.081156 & -0.808711 & -0.235318 \\ \mathrm{C} & 5.146054 & -1.695856 & -0.284674 \\ \mathrm{C} & 4.931862 & -3.067680 & -0.230080 \\ \mathrm{H} & 1.544393 & -3.057688 & 0.005764 \\ \mathrm{H} & 3.456915 & -4.627712 & -0.080566 \\ \mathrm{H} & 6.157931 & -1.308853 & -0.367118 \\ \mathrm{H} & 5.772170 & -3.754296 & -0.269419 \\ \mathrm{H} & 4.228867 & 0.264858 & -0.274151 \\ \mathrm{C} & -2.352569 & -2.528955 & 0.645562 \\ \mathrm{C} & -3.465270 & -0.781600 & -0.328865 \\ \mathrm{C} & -3.480730 & -3.327243 & 0.617213 \\ \mathrm{C} & -4.643408 & -1.504506 & -0.383375 \\ \mathrm{C} & -4.654339 & -2.803278 & 0.098889 \\ \mathrm{H} & -1.423273 & -2.915862 & 1.056080\end{array}$

$\begin{array}{lrrr}\mathrm{H} & -3.431331 & -4.340367 & 0.999416 \\ \mathrm{H} & -5.560730 & -3.399252 & 0.066763 \\ \mathrm{H} & -5.531822 & -1.049662 & -0.806508 \\ \mathrm{H} & -3.432254 & 0.228374 & -0.727085 \\ \mathrm{C} & -1.517592 & 2.188402 & -1.299124 \\ \mathrm{C} & -2.331475 & 3.294216 & -1.453705 \\ \mathrm{C} & -3.062648 & 3.746739 & -0.365852 \\ \mathrm{C} & -2.951591 & 3.072520 & 0.840282 \\ \mathrm{C} & -2.121792 & 1.970659 & 0.916122 \\ \mathrm{H} & -0.929686 & 1.809344 & -2.129698 \\ \mathrm{H} & -2.382951 & 3.787798 & -2.417203 \\ \mathrm{H} & -3.708478 & 4.613910 & -0.456685 \\ \mathrm{H} & -2.015469 & 1.413515 & 1.842370 \\ \mathrm{H} & -3.500962 & 3.387819 & 1.719672 \\ \mathrm{C} & 1.548988 & 0.880858 & -0.018930 \\ \mathrm{~N} & 2.442747 & 1.785792 & -0.009053 \\ \mathrm{C} & 2.174732 & 3.222624 & 0.108985 \\ \mathrm{C} & 3.483390 & 3.852029 & 0.578875 \\ \mathrm{H} & 3.761032 & 3.463830 & 1.565991 \\ \mathrm{H} & 4.295023 & 3.613907 & -0.118098 \\ \mathrm{H} & 3.394027 & 4.942809 & 0.648762 \\ \mathrm{C} & 1.083650 & 3.557322 & 1.118761 \\ \mathrm{H} & 0.096657 & 3.260662 & 0.758459 \\ \mathrm{H} & 1.269477 & 3.046760 & 2.071748 \\ \mathrm{H} & 1.058977 & 4.637436 & 1.308889 \\ \mathrm{C} & 1.819822 & 3.783801 & -1.263556 \\ \mathrm{H} & 2.613292 & 3.558489 & -1.985626 \\ \mathrm{H} & 0.888358 & 3.343571 & -1.636832 \\ \mathrm{H} & 1.692048 & 4.872987 & -1.221587 \\ \mathrm{Br} & -0.452718 & -1.154764 & -2.270762 \\ \mathrm{Br} & -0.190653 & -0.673298 & 2.482983\end{array}$

TS2 M06/6-311g(d,p)/superfine in PhCF3 Solvent Electronic energy -7030.815281 a.u. Gibbs free energy -7030.506411 (-7030.503344) a.u. 52

$\begin{array}{lrrr}\mathrm{Ti} & -0.486608 & -0.412059 & 0.021739 \\ \mathrm{~N} & -0.943354 & 1.527768 & -0.372686 \\ \mathrm{~N} & -2.700072 & -0.718149 & 0.335593 \\ \mathrm{~N} & 1.610460 & -0.506630 & -0.289116 \\ \mathrm{C} & 2.592873 & -1.530790 & -0.292533 \\ \mathrm{C} & 2.189104 & -2.836837 & -0.036144 \\ \mathrm{C} & 3.123599 & -3.860738 & -0.033461 \\ \mathrm{C} & 3.934892 & -1.253111 & -0.544324 \\ \mathrm{C} & 4.862354 & -2.283814 & -0.539985 \\ \mathrm{C} & 4.462607 & -3.589849 & -0.284934 \\ \mathrm{H} & 1.141311 & -3.044992 & 0.159614 \\ \mathrm{H} & 2.801780 & -4.878250 & 0.167409 \\ \mathrm{H} & 5.906855 & -2.062965 & -0.739393 \\ \mathrm{H} & 5.192364 & -4.393633 & -0.282009 \\ \mathrm{H} & 4.248536 & -0.232707 & -0.749477 \\ \mathrm{C} & -3.180523 & -1.679963 & 1.138890 \\ \mathrm{C} & -3.579958 & -0.065734 & -0.440939 \\ \mathrm{C} & -4.519034 & -2.015572 & 1.200010 \\ \mathrm{C} & -4.934922 & -0.345268 & -0.447144 \\ \mathrm{C} & -5.418158 & -1.337273 & 0.389781 \\ \mathrm{H} & -2.452910 & -2.196818 & 1.757437 \\ \mathrm{H} & -4.843491 & -2.803410 & 1.870382 \\ \mathrm{H} & -6.475803 & -1.579940 & 0.410102 \\ \mathrm{H} & -5.593594 & 0.214838 & -1.101321 \\ \mathrm{H} & -3.181903 & 0.707884 & -1.091155 \\ \mathrm{C} & -0.801764 & 2.066386 & -1.621007 \\ \mathrm{C} & -1.269924 & 3.316061 & -1.958688 \\ \mathrm{C} & -1.877075 & 4.118630 & -0.996876 \\ \mathrm{C} & -1.993900 & 3.596980 & 0.288582 \\ \mathrm{C} & -1.545115 & 2.324486 & 0.560956\end{array}$




$\begin{array}{lrrr}\mathrm{H} & -0.302275 & 1.443249 & -2.357685 \\ \mathrm{H} & -1.136222 & 3.662418 & -2.978488 \\ \mathrm{H} & -2.240812 & 5.111013 & -1.238239 \\ \mathrm{H} & -1.668563 & 1.891430 & 1.550260 \\ \mathrm{H} & -2.455299 & 4.167284 & 1.088369 \\ \mathrm{C} & 1.872388 & 0.721665 & -0.265060 \\ \mathrm{~N} & 2.336757 & 1.820421 & -0.434267 \\ \mathrm{C} & 2.598693 & 3.034762 & 0.349287 \\ \mathrm{C} & 4.109705 & 3.108524 & 0.533457 \\ \mathrm{H} & 4.474787 & 2.241034 & 1.094492 \\ \mathrm{H} & 4.617325 & 3.135731 & -0.436545 \\ \mathrm{H} & 4.372967 & 4.015539 & 1.088956 \\ \mathrm{C} & 1.904942 & 2.965792 & 1.699618 \\ \mathrm{H} & 0.819322 & 2.881873 & 1.579999 \\ \mathrm{H} & 2.261071 & 2.108441 & 2.281359 \\ \mathrm{H} & 2.117584 & 3.877915 & 2.268474 \\ \mathrm{C} & 2.107641 & 4.227959 & -0.453878 \\ \mathrm{H} & 2.568658 & 4.239967 & -1.447343 \\ \mathrm{H} & 1.019401 & 4.197838 & -0.575696 \\ \mathrm{H} & 2.372221 & 5.157262 & 0.062377 \\ \mathrm{Br} & -0.786459 & -1.698745 & -2.084564 \\ \mathrm{Br} & -0.151113 & -0.751350 & 2.455694\end{array}$

IM3 M06/6-311g(d,p)/superfine in PhCF3 Solvent Electronic energy -6493.947404 a.u.

Gibbs free energy -6493.839924 (-6493.837541) a.u.

$\begin{array}{lrrr}25 & & & \\ \mathrm{~N} & -0.722687 & -1.300001 & -0.403481 \\ \mathrm{~N} & -0.719119 & 1.308484 & 0.394437 \\ \mathrm{C} & -1.286816 & 2.076191 & -0.578506 \\ \mathrm{C} & -1.320971 & 1.324224 & 1.617434 \\ \mathrm{C} & -2.401644 & 2.853713 & -0.359978 \\ \mathrm{C} & -2.435422 & 2.085090 & 1.891369 \\ \mathrm{C} & -2.998915 & 2.875318 & 0.895856 \\ \mathrm{H} & -0.800833 & 2.065886 & -1.550401 \\ \mathrm{H} & -2.793586 & 3.445256 & -1.180561 \\ \mathrm{H} & -3.872679 & 3.486386 & 1.091760 \\ \mathrm{H} & -2.854128 & 2.054850 & 2.891682 \\ \mathrm{H} & -0.861757 & 0.717155 & 2.392977 \\ \mathrm{C} & -1.316440 & -2.013436 & 0.594724 \\ \mathrm{C} & -2.428274 & -2.800004 & 0.389772 \\ \mathrm{C} & -2.997517 & -2.882083 & -0.875745 \\ \mathrm{C} & -2.409932 & -2.142319 & -1.896839 \\ \mathrm{C} & -1.297493 & -1.374665 & -1.637348 \\ \mathrm{H} & -0.853394 & -1.954715 & 1.576071 \\ \mathrm{H} & -2.840673 & -3.348771 & 1.229814 \\ \mathrm{H} & -3.868860 & -3.499988 & -1.060642 \\ \mathrm{H} & -0.818052 & -0.807734 & -2.430877 \\ \mathrm{H} & -2.807507 & -2.159771 & -2.906016 \\ \mathrm{Br} & 2.035240 & 0.609029 & -1.973974 \\ \mathrm{Br} & 2.058398 & -0.613206 & 1.910775 \\ \mathrm{Ti} & 0.768414 & 0.006489 & -0.020631\end{array}$




\section{$\mathbf{L}=$ pyridine/isocyanide (green)}

IM0 M06/6-311g(d,p)/superfine in PhCF3 Solvent Electronic energy -6782.674877 a.u.

Gibbs free energy -6782.445253 (-6782.442749) a.u. 41

$\begin{array}{lrrr}\mathrm{Ti} & -0.419490 & 0.588956 & -0.598063 \\ \mathrm{~N} & -1.241514 & -0.729903 & 0.048115 \\ \mathrm{C} & -2.005654 & -1.753219 & 0.541183 \\ \mathrm{C} & -1.663606 & -3.092788 & 0.295355 \\ \mathrm{C} & -2.435526 & -4.119139 & 0.815243 \\ \mathrm{C} & -3.142731 & -1.479880 & 1.318550 \\ \mathrm{C} & -3.908834 & -2.514722 & 1.829660 \\ \mathrm{C} & -3.560389 & -3.838779 & 1.584090 \\ \mathrm{H} & -0.784753 & -3.302287 & -0.308695 \\ \mathrm{H} & -2.157818 & -5.150848 & 0.617282 \\ \mathrm{H} & -4.787698 & -2.286279 & 2.426530 \\ \mathrm{H} & -4.162668 & -4.647060 & 1.987622 \\ \mathrm{H} & -3.408367 & -0.440914 & 1.499667 \\ \mathrm{Br} & -1.966421 & 2.533875 & -0.498518 \\ \mathrm{Br} & -0.283526 & 0.256557 & -3.055552 \\ \mathrm{C} & 1.593186 & -0.417056 & -0.544602 \\ \mathrm{~N} & 2.601803 & -0.965767 & -0.401856 \\ \mathrm{C} & 3.870403 & -1.627250 & -0.151918 \\ \mathrm{C} & 4.505233 & -0.922403 & 1.038015 \\ \mathrm{C} & 3.570851 & -3.085719 & 0.158170 \\ \mathrm{C} & 4.720745 & -1.486114 & -1.404140 \\ \mathrm{H} & 3.863967 & -0.998662 & 1.922340 \\ \mathrm{H} & 5.467030 & -1.394569 & 1.261672 \\ \mathrm{H} & 4.678379 & 0.135830 & 0.816409 \\ \mathrm{H} & 3.080340 & -3.571691 & -0.690823 \\ \mathrm{H} & 4.512414 & -3.605376 & 0.361845 \\ \mathrm{H} & 2.925563 & -3.172976 & 1.037730 \\ \mathrm{H} & 5.684970 & -1.975520 & -1.234814 \\ \mathrm{H} & 4.234262 & -1.960995 & -2.261512 \\ \mathrm{H} & 4.900470 & -0.432158 & -1.637534 \\ \mathrm{~N} & 0.503780 & 1.370063 & 1.257300 \\ \mathrm{C} & 1.500210 & 2.261616 & 1.175919 \\ \mathrm{C} & 0.062351 & 1.000308 & 2.464996 \\ \mathrm{C} & 2.091335 & 2.816711 & 2.293730 \\ \mathrm{H} & 1.827694 & 2.534426 & 0.173851 \\ \mathrm{C} & 0.603294 & 1.508680 & 3.632243 \\ \mathrm{H} & -0.749134 & 0.278915 & 2.481848 \\ \mathrm{C} & 1.635041 & 2.430275 & 3.546283 \\ \mathrm{H} & 2.893021 & 3.537108 & 2.179507 \\ \mathrm{H} & 0.216116 & 1.181446 & 4.590195 \\ \mathrm{H} & 2.079175 & 2.845595 & 4.445163 \\ & & & \end{array}$

IM1 M06/6-311g(d,p)/superfine in PhCF3 Solvent Electronic energy -7033.244093 a.u.

Gibbs free energy -7032.905531 (-7032.899701) a.u.

$\begin{array}{ll}56 & \\ \mathrm{Ti} & -0.121179 \\ \mathrm{~N} & 0.849937 \\ \mathrm{~N} & -1.741400 \\ \mathrm{C} & -3.074668 \\ \mathrm{C} & -3.939446 \\ \mathrm{C} & -5.293822 \\ \mathrm{C} & -3.624215 \\ \mathrm{C} & -4.979961 \\ \mathrm{C} & -5.824946 \\ \mathrm{H} & -3.513955 \\ \mathrm{H} & -5.944820 \\ \mathrm{H} & -5.384448 \\ \mathrm{H} & -6.887502 \\ \mathrm{H} & -2.961221\end{array}$

$$
\begin{array}{r}
-0.364121 \\
-2.376186 \\
-0.866397 \\
-1.134357 \\
-0.303458 \\
-0.581977 \\
-2.253956 \\
-2.525261 \\
-1.692963 \\
0.555613 \\
0.072961 \\
-3.395753 \\
-1.908055 \\
-2.897008
\end{array}
$$

$\begin{array}{lrrr}\mathrm{C} & 0.168045 & -3.389954 & -0.490346 \\ \mathrm{C} & 2.071838 & -2.627552 & 0.551513 \\ \mathrm{C} & 0.680182 & -4.670536 & -0.582059 \\ \mathrm{C} & 2.656769 & -3.878737 & 0.494910 \\ \mathrm{C} & 1.949057 & -4.920909 & -0.083390 \\ \mathrm{H} & -0.820205 & -3.153144 & -0.872500 \\ \mathrm{H} & 0.085731 & -5.454113 & -1.037605 \\ \mathrm{H} & 2.378788 & -5.915875 & -0.141019 \\ \mathrm{H} & 3.649700 & -4.026253 & 0.904191 \\ \mathrm{H} & 2.590591 & -1.793378 & 1.015866 \\ \mathrm{C} & -0.744451 & 1.789149 & 0.061713 \\ \mathrm{~N} & -1.157141 & 2.871119 & 0.060159 \\ \mathrm{C} & -1.684956 & 4.222914 & 0.068404 \\ \mathrm{C} & -3.117032 & 4.155976 & -0.440083 \\ \mathrm{H} & -3.149798 & 3.761123 & -1.460419 \\ \mathrm{H} & -3.730052 & 3.519858 & 0.206060 \\ \mathrm{H} & -3.541614 & 5.164872 & -0.442327 \\ \mathrm{C} & -0.808710 & 5.061907 & -0.849088 \\ \mathrm{H} & 0.226697 & 5.074376 & -0.494635 \\ \mathrm{H} & -0.828256 & 4.670975 & -1.871032 \\ \mathrm{H} & -1.186250 & 6.089206 & -0.860650 \\ \mathrm{C} & -1.628075 & 4.725100 & 1.503041 \\ \mathrm{H} & -2.234033 & 4.094332 & 2.160605 \\ \mathrm{H} & -0.597990 & 4.733344 & 1.872594 \\ \mathrm{H} & -2.020459 & 5.746341 & 1.538403 \\ \mathrm{Br} & 0.566535 & 0.004433 & 2.510666 \\ \mathrm{Br} & -0.133051 & -0.278543 & -2.459294 \\ \mathrm{C} & 2.078297 & 0.508625 & -0.250134 \\ \mathrm{~N} & 3.183003 & 0.857033 & -0.314073 \\ \mathrm{C} & 4.581205 & 1.240052 & -0.288419 \\ \mathrm{C} & 5.360436 & 0.165058 & -1.030955 \\ \mathrm{C} & 4.708252 & 2.591206 & -0.973805 \\ \mathrm{C} & 4.995589 & 1.315473 & 1.173693 \\ \mathrm{H} & 5.030603 & 0.093633 & -2.071944 \\ \mathrm{H} & 6.424945 & 0.419578 & -1.017624 \\ \mathrm{H} & 5.229136 & -0.810940 & -0.551788 \\ \mathrm{H} & 4.115736 & 3.349301 & -0.452089 \\ \mathrm{H} & 5.758143 & 2.900542 & -0.962767 \\ \mathrm{H} & 4.371956 & 2.533474 & -2.013589 \\ \mathrm{H} & 6.052506 & 1.593824 & 1.235484 \\ \mathrm{H} & 4.403353 & 2.065310 & 1.707796 \\ \mathrm{H} & 4.859608 & 0.346588 & 1.666290\end{array}$

TS1 M06/6-311g(d,p)/superfine in PhCF3 Solvent Electronic energy -7033.209891 a.u. Gibbs free energy -7032.867819 (-7032.863381) a.u. 56

$\begin{array}{lrrr}\mathrm{Ti} & 0.017858 & 0.579581 & 0.009306 \\ \mathrm{~N} & 1.268329 & 2.439834 & 0.140169 \\ \mathrm{~N} & -1.746850 & 0.631539 & -0.098116 \\ \mathrm{C} & -3.121981 & 0.730623 & -0.120499 \\ \mathrm{C} & -3.901740 & 0.283529 & 0.953475 \\ \mathrm{C} & -5.278590 & 0.437030 & 0.920139 \\ \mathrm{C} & -3.749480 & 1.307949 & -1.229873 \\ \mathrm{C} & -5.127783 & 1.453300 & -1.253336 \\ \mathrm{C} & -5.897826 & 1.020533 & -0.179912 \\ \mathrm{H} & -3.410427 & -0.167383 & 1.811469 \\ \mathrm{H} & -5.875532 & 0.098170 & 1.762334 \\ \mathrm{H} & -5.604806 & 1.907681 & -2.117226 \\ \mathrm{H} & -6.977212 & 1.137446 & -0.200011 \\ \mathrm{H} & -3.132887 & 1.639700 & -2.061197 \\ \mathrm{C} & 0.622179 & 3.571799 & -0.166356 \\ \mathrm{C} & 2.552665 & 2.514928 & 0.507602 \\ \mathrm{C} & 1.228479 & 4.812935 & -0.116399 \\ \mathrm{C} & 3.234846 & 3.714961 & 0.572903 \\ \mathrm{C} & 2.561149 & 4.885494 & 0.257629\end{array}$




$\begin{array}{lrrr}\mathrm{H} & -0.420264 & 3.471549 & -0.464235 \\ \mathrm{H} & 0.660770 & 5.700832 & -0.369373 \\ \mathrm{H} & 3.069343 & 5.843226 & 0.304189 \\ \mathrm{H} & 4.276751 & 3.725595 & 0.871505 \\ \mathrm{H} & 3.044929 & 1.580073 & 0.761430 \\ \mathrm{C} & -1.195489 & -1.025718 & -0.070265 \\ \mathrm{~N} & -2.029576 & -1.908054 & -0.086929 \\ \mathrm{C} & -1.779860 & -3.352966 & 0.048034 \\ \mathrm{C} & -2.415856 & -3.763022 & 1.369217 \\ \mathrm{H} & -1.931161 & -3.245451 & 2.205886 \\ \mathrm{H} & -3.481594 & -3.509146 & 1.378642 \\ \mathrm{H} & -2.311457 & -4.843322 & 1.521441 \\ \mathrm{C} & -0.293393 & -3.678624 & 0.047355 \\ \mathrm{H} & 0.176764 & -3.354610 & -0.889708 \\ \mathrm{H} & 0.217679 & -3.181416 & 0.881172 \\ \mathrm{H} & -0.147645 & -4.760270 & 0.149700 \\ \mathrm{C} & -2.478466 & -4.037297 & -1.116129 \\ \mathrm{H} & -3.545123 & -3.789942 & -1.124685 \\ \mathrm{H} & -2.043250 & -3.717953 & -2.069673 \\ \mathrm{H} & -2.371854 & -5.124825 & -1.033970 \\ \mathrm{Br} & 0.570174 & 0.605165 & -2.452824 \\ \mathrm{Br} & 0.217846 & 0.506324 & 2.518110 \\ \mathrm{C} & 1.892621 & -0.742473 & 0.063615 \\ \mathrm{~N} & 2.778645 & -1.487464 & 0.011003 \\ \mathrm{C} & 3.894204 & -2.400820 & -0.149378 \\ \mathrm{C} & 5.130906 & -1.706691 & 0.401033 \\ \mathrm{C} & 3.575568 & -3.667192 & 0.630016 \\ \mathrm{C} & 4.029222 & -2.681671 & -1.638519 \\ \mathrm{H} & 5.009711 & -1.481665 & 1.465319 \\ \mathrm{H} & 5.995129 & -2.367352 & 0.280341 \\ \mathrm{H} & 5.326285 & -0.774561 & -0.138863 \\ \mathrm{H} & 2.681009 & -4.156620 & 0.232121 \\ \mathrm{H} & 4.418583 & -4.359924 & 0.542886 \\ \mathrm{H} & 3.415388 & -3.443610 & 1.689466 \\ \mathrm{H} & 4.860475 & -3.375658 & -1.798669 \\ \mathrm{H} & 3.113992 & -3.135130 & -2.033105 \\ \mathrm{H} & 4.230762 & -1.758970 & -2.191940\end{array}$

IM2 M06/6-311g(d,p)/superfine in PhCF3 Solvent Electronic energy -7033.232472 a.u.

Gibbs free energy -7032.883003 (-7032.880328) a.u. 56

$\begin{array}{lrrr}\mathrm{Ti} & 0.203932 & -0.528405 & -0.034155 \\ \mathrm{~N} & 1.959670 & 0.198890 & 0.012177 \\ \mathrm{C} & 3.320994 & -0.059529 & 0.085213 \\ \mathrm{C} & 3.755950 & -1.388047 & 0.129833 \\ \mathrm{C} & 5.107625 & -1.675727 & 0.204745 \\ \mathrm{C} & 4.258087 & 0.977112 & 0.115426 \\ \mathrm{C} & 5.609666 & 0.675036 & 0.191152 \\ \mathrm{C} & 6.041534 & -0.644959 & 0.236347 \\ \mathrm{H} & 3.017347 & -2.187406 & 0.100412 \\ \mathrm{H} & 5.437017 & -2.710177 & 0.238333 \\ \mathrm{H} & 6.335239 & 1.483349 & 0.214913 \\ \mathrm{H} & 7.101821 & -0.871416 & 0.295163 \\ \mathrm{H} & 3.901786 & 2.001017 & 0.077540 \\ \mathrm{C} & 1.237997 & 1.314026 & -0.075662 \\ \mathrm{~N} & 1.574420 & 2.536521 & -0.124874 \\ \mathrm{C} & 0.592684 & 3.626666 & -0.226647 \\ \mathrm{C} & 1.400450 & 4.916553 & -0.315042 \\ \mathrm{H} & 2.036796 & 5.031022 & 0.570154 \\ \mathrm{H} & 2.049450 & 4.902423 & -1.198318 \\ \mathrm{H} & 0.741601 & 5.790722 & -0.383702 \\ \mathrm{C} & -0.277892 & 3.678731 & 1.024576 \\ \mathrm{H} & -0.860448 & 2.761066 & 1.148793 \\ \mathrm{H} & 0.351837 & 3.795938 & 1.914812 \\ \mathrm{H} & -0.972385 & 4.528236 & 0.983927\end{array}$

$\begin{array}{lrrr}\mathrm{C} & -0.249571 & 3.489689 & -1.490291 \\ \mathrm{H} & 0.401729 & 3.446581 & -2.371679 \\ \mathrm{H} & -0.855370 & 2.578857 & -1.479439 \\ \mathrm{H} & -0.922567 & 4.349058 & -1.605353 \\ \mathrm{Br} & 0.173011 & -0.915192 & -2.477894 \\ \mathrm{Br} & -0.017136 & -0.715555 & 2.430819 \\ \mathrm{C} & -1.652965 & 0.602000 & -0.042545 \\ \mathrm{~N} & -2.679788 & 1.132199 & 0.034100 \\ \mathrm{C} & -3.959686 & 1.797678 & 0.209264 \\ \mathrm{C} & -5.039627 & 0.841787 & -0.273798 \\ \mathrm{C} & -4.102747 & 2.093155 & 1.695398 \\ \mathrm{C} & -3.939305 & 3.074989 & -0.615304 \\ \mathrm{H} & -5.031217 & -0.084170 & 0.310141 \\ \mathrm{H} & -6.016351 & 1.320221 & -0.151509 \\ \mathrm{H} & -4.901679 & 0.599669 & -1.332455 \\ \mathrm{H} & -3.304455 & 2.757068 & 2.041776 \\ \mathrm{H} & -5.065113 & 2.585711 & 1.866722 \\ \mathrm{H} & -4.073469 & 1.168776 & 2.280913 \\ \mathrm{H} & -4.902128 & 3.582534 & -0.500006 \\ \mathrm{H} & -3.147435 & 3.749239 & -0.274718 \\ \mathrm{H} & -3.786358 & 2.854470 & -1.676514 \\ \mathrm{~N} & -1.139328 & -2.379952 & -0.037373 \\ \mathrm{C} & -2.388594 & -2.465486 & -0.508199 \\ \mathrm{C} & -0.547275 & -3.502876 & 0.387155 \\ \mathrm{C} & -3.090488 & -3.655956 & -0.550406 \\ \mathrm{H} & -2.839150 & -1.547567 & -0.873767 \\ \mathrm{C} & -1.169016 & -4.737017 & 0.361660 \\ \mathrm{H} & 0.468322 & -3.410075 & 0.768423 \\ \mathrm{C} & -2.470432 & -4.814526 & -0.109222 \\ \mathrm{H} & -4.105007 & -3.667442 & -0.932114 \\ \mathrm{H} & -0.638208 & -5.614804 & 0.711514 \\ \mathrm{H} & -2.992881 & -5.765268 & -0.135041 \\ & & & \end{array}$

TS2 M06/6-311g(d,p)/superfine in PhCF3 Solvent Electronic energy -7033.209550 a.u. Gibbs free energy -7032.864251 (-7032.860688) a.u. 56

$\begin{array}{lrrr}\mathrm{Ti} & 0.221771 & -0.614214 & 0.080192 \\ \mathrm{~N} & 2.170812 & -1.659437 & -0.406826 \\ \mathrm{~N} & -1.764736 & -0.145416 & 0.439939 \\ \mathrm{C} & -2.984427 & -0.856920 & 0.458770 \\ \mathrm{C} & -2.941986 & -2.247627 & 0.523600 \\ \mathrm{C} & -4.120462 & -2.975943 & 0.553976 \\ \mathrm{C} & -4.214234 & -0.200946 & 0.422606 \\ \mathrm{C} & -5.387825 & -0.939180 & 0.453526 \\ \mathrm{C} & -5.348275 & -2.326237 & 0.519603 \\ \mathrm{H} & -1.980449 & -2.754021 & 0.553489 \\ \mathrm{H} & -4.078452 & -4.059904 & 0.604999 \\ \mathrm{H} & -6.342843 & -0.422636 & 0.426377 \\ \mathrm{H} & -6.270236 & -2.898928 & 0.542865 \\ \mathrm{H} & -4.246752 & 0.884095 & 0.374322 \\ \mathrm{C} & 2.319702 & -2.967603 & -0.161545 \\ \mathrm{C} & 3.142836 & -1.036145 & -1.085722 \\ \mathrm{C} & 3.430565 & -3.686559 & -0.562147 \\ \mathrm{C} & 4.287742 & -1.677922 & -1.520214 \\ \mathrm{C} & 4.437979 & -3.029461 & -1.250881 \\ \mathrm{H} & 1.513554 & -3.454483 & 0.380725 \\ \mathrm{H} & 3.496287 & -4.744450 & -0.334889 \\ \mathrm{H} & 5.325146 & -3.563383 & -1.576072 \\ \mathrm{H} & 5.044210 & -1.120287 & -2.060623 \\ \mathrm{H} & 2.988120 & 0.019883 & -1.291038 \\ \mathrm{C} & -1.652702 & 1.087839 & 0.158001 \\ \mathrm{~N} & -2.009319 & 2.239164 & 0.055762 \\ \mathrm{C} & -1.786155 & 3.411956 & -0.791300 \\ \mathrm{C} & -3.159676 & 3.815002 & -1.317154 \\ \mathrm{H} & -3.592461 & 3.011014 & -1.923051\end{array}$




$\begin{array}{lrrr}\mathrm{H} & -3.842497 & 4.030601 & -0.488210 \\ \mathrm{H} & -3.074636 & 4.712175 & -1.940354 \\ \mathrm{C} & -0.859462 & 3.090809 & -1.953888 \\ \mathrm{H} & 0.134478 & 2.796832 & -1.604113 \\ \mathrm{H} & -1.267426 & 2.278452 & -2.565471 \\ \mathrm{H} & -0.752990 & 3.978012 & -2.588598 \\ \mathrm{C} & -1.214171 & 4.525086 & 0.074477 \\ \mathrm{H} & -1.884077 & 4.743097 & 0.913089 \\ \mathrm{H} & -0.237910 & 4.233871 & 0.475082 \\ \mathrm{H} & -1.097550 & 5.437758 & -0.520909 \\ \mathrm{Br} & 0.427942 & -1.545783 & 2.349717 \\ \mathrm{Br} & -0.269860 & -1.073009 & -2.298031 \\ \mathrm{C} & 1.031601 & 1.176071 & 0.351560 \\ \mathrm{~N} & 1.409314 & 2.279427 & 0.638025 \\ \mathrm{C} & 2.707050 & 2.901299 & 0.963816 \\ \mathrm{C} & 3.722235 & 1.836064 & 1.344382 \\ \mathrm{C} & 3.143840 & 3.661950 & -0.279393 \\ \mathrm{C} & 2.469428 & 3.855562 & 2.123015 \\ \mathrm{H} & 3.933431 & 1.171661 & 0.500198 \\ \mathrm{H} & 4.661040 & 2.310020 & 1.651336 \\ \mathrm{H} & 3.352393 & 1.228685 & 2.178426 \\ \mathrm{H} & 2.402804 & 4.420018 & -0.555786 \\ \mathrm{H} & 4.097329 & 4.165204 & -0.085101 \\ \mathrm{H} & 3.277248 & 2.979634 & -1.126782 \\ \mathrm{H} & 3.407108 & 4.356577 & 2.386723 \\ \mathrm{H} & 1.730721 & 4.618885 & 1.857833 \\ \mathrm{H} & 2.108436 & 3.313305 & 3.003488\end{array}$

IM3 M06/6-311g(d,p)/superfine in PhCF3 Solvent Electronic energy -6496.342688 a.u.

Gibbs free energy -6496.196729 (-6496.194431) a.u.

$\begin{array}{lccc}29 & & & \\ \mathrm{~N} & 1.948937 & 0.856781 & -0.080507 \\ \mathrm{C} & 3.151533 & 0.265932 & 0.037896 \\ \mathrm{C} & 1.905074 & 2.190323 & -0.236986 \\ \mathrm{C} & 4.336420 & 0.972017 & 0.007061 \\ \mathrm{C} & 3.047531 & 2.966326 & -0.278576 \\ \mathrm{C} & 4.282849 & 2.348995 & -0.154041 \\ \mathrm{H} & 3.154226 & -0.815250 & 0.162644 \\ \mathrm{H} & 5.279569 & 0.447744 & 0.108174 \\ \mathrm{H} & 5.196109 & 2.934506 & -0.181798 \\ \mathrm{H} & 2.961625 & 4.039118 & -0.406777 \\ \mathrm{H} & 0.915659 & 2.625869 & -0.328554 \\ \mathrm{Br} & 0.311477 & -1.852402 & -1.920122 \\ \mathrm{Br} & 0.152784 & -1.320051 & 2.239578 \\ \mathrm{Ti} & 0.238433 & -0.436025 & 0.012231 \\ \mathrm{C} & -1.169102 & 0.862164 & -0.183046 \\ \mathrm{~N} & -2.132973 & 1.607751 & -0.247377 \\ \mathrm{C} & -3.563009 & 1.197694 & -0.150499 \\ \mathrm{C} & -3.750015 & -0.271519 & -0.487104 \\ \mathrm{C} & -3.977911 & 1.479996 & 1.286645 \\ \mathrm{C} & -4.338372 & 2.077519 & -1.116053 \\ \mathrm{H} & -3.172565 & -0.910842 & 0.191005 \\ \mathrm{H} & -4.808012 & -0.542716 & -0.400466 \\ \mathrm{H} & -3.421698 & -0.482094 & -1.512083 \\ \mathrm{H} & -3.801508 & 2.530186 & 1.543634 \\ \mathrm{H} & -5.044680 & 1.264946 & 1.417041 \\ \mathrm{H} & -3.408118 & 0.851935 & 1.981960 \\ \mathrm{H} & -5.409556 & 1.854317 & -1.055954 \\ \mathrm{H} & -4.188542 & 3.136305 & -0.878242 \\ \mathrm{H} & -4.008919 & 1.905963 & -2.147201 \\ & & & \\ & & & \end{array}$




\section{$\mathrm{L}=$ isocyanide/isocyanide (black)}

IM0 M06/6-311g(d,p)/superfine in PhCF3 Solvent Electronic energy -6785.053321 a.u.

Gibbs free energy -6784.789875 (-6784.786078) a.u. 45

$\begin{array}{lrrr}\mathrm{Ti} & 0.024534 & -0.265640 & 1.669948 \\ \mathrm{~N} & 1.138003 & -0.446723 & 0.416490 \\ \mathrm{C} & 2.218671 & -0.410530 & -0.424203 \\ \mathrm{C} & 2.426754 & -1.408903 & -1.387759 \\ \mathrm{C} & 3.524007 & -1.349720 & -2.231844 \\ \mathrm{C} & 3.144316 & 0.642872 & -0.334438 \\ \mathrm{C} & 4.236325 & 0.692569 & -1.184363 \\ \mathrm{C} & 4.432946 & -0.301474 & -2.137614 \\ \mathrm{H} & 1.712909 & -2.225205 & -1.453721 \\ \mathrm{H} & 3.672684 & -2.131308 & -2.971894 \\ \mathrm{H} & 4.944303 & 1.512736 & -1.101229 \\ \mathrm{H} & 5.291104 & -0.260486 & -2.801542 \\ \mathrm{H} & 2.984566 & 1.409834 & 0.420201 \\ \mathrm{Br} & 1.338971 & 0.377169 & 3.657959 \\ \mathrm{Br} & -0.872055 & -2.489566 & 2.316373 \\ \mathrm{C} & -0.113566 & 1.931331 & 1.267914 \\ \mathrm{~N} & -0.013472 & 3.048526 & 0.984295 \\ \mathrm{C} & 0.186051 & 4.447077 & 0.646594 \\ \mathrm{C} & 0.559640 & 4.508109 & -0.826512 \\ \mathrm{C} & 1.312462 & 4.961315 & 1.530152 \\ \mathrm{C} & -1.118156 & 5.178237 & 0.922812 \\ \mathrm{H} & 0.726904 & 5.552668 & -1.107216 \\ \mathrm{H} & 1.476403 & 3.942405 & -1.020139 \\ \mathrm{H} & -0.243804 & 4.103203 & -1.449588 \\ \mathrm{H} & 1.491284 & 6.016313 & 1.300191 \\ \mathrm{H} & 1.048825 & 4.873557 & 2.588690 \\ \mathrm{H} & 2.236101 & 4.402436 & 1.348594 \\ \mathrm{H} & -0.991215 & 6.236128 & 0.672810 \\ \mathrm{H} & -1.930634 & 4.770897 & 0.313044 \\ \mathrm{H} & -1.393053 & 5.099897 & 1.979082 \\ \mathrm{C} & -1.837690 & -0.171981 & 0.419163 \\ \mathrm{~N} & -2.765737 & -0.231893 & -0.268541 \\ \mathrm{C} & -3.928359 & -0.407334 & -1.122082 \\ \mathrm{C} & -3.477258 & -0.184113 & -2.557129 \\ \mathrm{C} & -4.968294 & 0.617869 & -0.699098 \\ \mathrm{C} & -4.424632 & -1.829193 & -0.907213 \\ \mathrm{H} & -4.335112 & -0.319518 & -3.223123 \\ \mathrm{H} & -3.087917 & 0.829886 & -2.690625 \\ \mathrm{H} & -2.700392 & -0.901865 & -2.837472 \\ \mathrm{H} & -5.855335 & 0.502983 & -1.329696 \\ \mathrm{H} & -5.261010 & 0.469315 & 0.344802 \\ \mathrm{H} & -4.584594 & 1.635776 & -0.819385 \\ \mathrm{H} & -5.302187 & -1.998658 & -1.538959 \\ \mathrm{H} & -3.652191 & -2.555621 & -1.178299 \\ \mathrm{H} & -4.708700 & -1.989378 & 0.137570 \\ & & & \end{array}$

IM1 M06/6-311g(d,p)/superfine in PhCF3 Solvent Electronic energy -7035.622424 a.u.

Gibbs free energy -7035.252197 (-7035.243888) a.u. 60

$\begin{array}{llll}\mathrm{Ti} & -0.071521 & -0.277815 & 0.142676 \\ \mathrm{~N} & -1.173559 & -1.581059 & 0.106024 \\ \mathrm{C} & -2.172470 & -2.489552 & -0.066345 \\ \mathrm{C} & -3.277818 & -2.187672 & -0.884357 \\ \mathrm{C} & -4.300504 & -3.105266 & -1.055780 \\ \mathrm{C} & -2.134487 & -3.747011 & 0.562382 \\ \mathrm{C} & -3.159465 & -4.659655 & 0.375583 \\ \mathrm{C} & -4.249796 & -4.347052 & -0.429939 \\ \mathrm{H} & -3.303031 & -1.219197 & -1.378494 \\ \mathrm{H} & -5.146353 & -2.851944 & -1.689795\end{array}$

\begin{tabular}{|c|c|c|}
\hline-3.110080 & -5.627078 & 0.868604 \\
\hline-5.052369 & -5.064972 & -0.569580 \\
\hline-1.283482 & -3.984473 & 1.195222 \\
\hline-1.756362 & 1.206020 & 0.175214 \\
\hline-2.693715 & 1.885305 & 0.182832 \\
\hline-3.879351 & 2.723104 & 0.190712 \\
\hline-4.988022 & 1.946963 & -0.503796 \\
\hline-4.713776 & 1.717897 & -1.538385 \\
\hline-5.196473 & 1.010581 & 0.023185 \\
\hline-5.897952 & 2.555368 & -0.510017 \\
\hline-3.540354 & 4.001448 & -0.560458 \\
\hline-2.717492 & 4.533333 & -0.072618 \\
\hline-3.257301 & 3.782297 & -1.594620 \\
\hline-4.420259 & 4.652431 & -0.569567 \\
\hline-4.226597 & 3.007731 & 1.643951 \\
\hline-4.433866 & 2.078950 & 2.184055 \\
\hline-3.407760 & 3.533037 & 2.145060 \\
\hline-5.119962 & 3.639302 & 1.677770 \\
\hline 0.242223 & 0.004277 & 2.636916 \\
\hline 0.128099 & 0.028065 & -2.376915 \\
\hline 1.310766 & 1.665170 & 0.060870 \\
\hline 1.981234 & 2.605464 & -0.049274 \\
\hline 2.815671 & 3.772453 & -0.261289 \\
\hline 3.448942 & 3.629701 & -1.637233 \\
\hline 1.914857 & 4.996448 & -0.191049 \\
\hline 3.868331 & 3.796873 & 0.835811 \\
\hline 2.680017 & 3.566554 & -2.413891 \\
\hline 4.077692 & 4.503346 & -1.836542 \\
\hline 4.072604 & 2.731442 & -1.686395 \\
\hline 1.434736 & 5.070570 & 0.789664 \\
\hline 2.519006 & 5.894799 & -0.352654 \\
\hline 1.139590 & 4.953494 & -0.962508 \\
\hline 4.513056 & 4.670103 & 0.694217 \\
\hline 3.400663 & 3.864104 & 1.822930 \\
\hline 4.488796 & 2.895875 & 0.800163 \\
\hline 1.854917 & -1.446833 & 0.075679 \\
\hline 2.834904 & -2.060983 & 0.035502 \\
\hline 4.065623 & -2.829485 & -0.019941 \\
\hline 5.220520 & -1.844688 & 0.081640 \\
\hline 4.054163 & -3.795233 & 1.154977 \\
\hline 4.081512 & -3.569523 & -1.348678 \\
\hline 5.178560 & -1.290890 & 1.024642 \\
\hline 6.163796 & -2.398571 & 0.043489 \\
\hline 5.199544 & -1.132719 & -0.749385 \\
\hline 3.199342 & -4.475457 & 1.092259 \\
\hline 4.974419 & -4.387542 & 1.136416 \\
\hline 4.006223 & -3.253347 & 2.104481 \\
\hline 5.003301 & -4.155820 & -1.416915 \\
\hline 3.227756 & -4.249553 & -1.426031 \\
\hline 4.050729 & -2.866703 & -2.186983 \\
\hline
\end{tabular}

TS1 M06/6-311 g(d,p)/superfine in PhCF3 Solvent Electronic energy -7035.588532 a.u. Gibbs free energy -7035.212645 (-7035.206834) a.u. 60

$\begin{array}{lllr}\mathrm{Ti} & 0.002965 & -0.491166 & 0.090730 \\ \mathrm{~N} & -1.601821 & -1.238290 & 0.052129 \\ \mathrm{C} & -2.835859 & -1.843558 & -0.069038 \\ \mathrm{C} & -3.641500 & -1.627531 & -1.193846 \\ \mathrm{C} & -4.859010 & -2.279040 & -1.309077 \\ \mathrm{C} & -3.284400 & -2.700079 & 0.941700 \\ \mathrm{C} & -4.505319 & -3.344679 & 0.816942 \\ \mathrm{C} & -5.296621 & -3.138689 & -0.307189 \\ \mathrm{H} & -3.290279 & -0.956720 & -1.973458 \\ \mathrm{H} & -5.473225 & -2.114781 & -2.190065 \\ \mathrm{H} & -4.842327 & -4.012586 & 1.604714\end{array}$




$\begin{array}{lrrr}\mathrm{H} & -6.251832 & -3.646208 & -0.402852 \\ \mathrm{H} & -2.654151 & -2.849997 & 1.814136 \\ \mathrm{C} & -1.744991 & 0.498067 & 0.210738 \\ \mathrm{~N} & -2.853249 & 0.988480 & 0.217782 \\ \mathrm{C} & -3.210716 & 2.415337 & 0.188706 \\ \mathrm{C} & -3.920696 & 2.635906 & -1.140142 \\ \mathrm{H} & -3.245049 & 2.420483 & -1.976836 \\ \mathrm{H} & -4.793023 & 1.978474 & -1.224491 \\ \mathrm{H} & -4.255877 & 3.676037 & -1.222036 \\ \mathrm{C} & -1.983642 & 3.308344 & 0.294418 \\ \mathrm{H} & -1.448977 & 3.129391 & 1.235118 \\ \mathrm{H} & -1.292902 & 3.121541 & -0.537707 \\ \mathrm{H} & -2.284293 & 4.362006 & 0.263913 \\ \mathrm{C} & -4.159781 & 2.664650 & 1.349849 \\ \mathrm{H} & -5.032129 & 2.006281 & 1.282702 \\ \mathrm{H} & -3.658849 & 2.477318 & 2.306056 \\ \mathrm{H} & -4.504256 & 3.704735 & 1.337381 \\ \mathrm{Br} & 0.505092 & -0.682295 & 2.541459 \\ \mathrm{Br} & 0.271139 & -0.123585 & -2.394933 \\ \mathrm{C} & 1.192888 & 1.466397 & 0.187539 \\ \mathrm{~N} & 1.706557 & 2.504625 & 0.159001 \\ \mathrm{C} & 2.350343 & 3.798888 & 0.030967 \\ \mathrm{C} & 2.334926 & 4.158705 & -1.447429 \\ \mathrm{C} & 1.554232 & 4.798612 & 0.855458 \\ \mathrm{C} & 3.771319 & 3.657153 & 0.554556 \\ \mathrm{H} & 1.308388 & 4.213842 & -1.824449 \\ \mathrm{H} & 2.810368 & 5.135237 & -1.583872 \\ \mathrm{H} & 2.884769 & 3.415956 & -2.034211 \\ \mathrm{H} & 1.516238 & 4.495164 & 1.906370 \\ \mathrm{H} & 2.039617 & 5.777620 & 0.792023 \\ \mathrm{H} & 0.531682 & 4.892669 & 0.476600 \\ \mathrm{H} & 4.284355 & 4.619156 & 0.458623 \\ \mathrm{H} & 3.770314 & 3.365399 & 1.609295 \\ \mathrm{H} & 4.324899 & 2.907865 & -0.019928 \\ \mathrm{C} & 2.049686 & -1.497547 & -0.111031 \\ \mathrm{~N} & 3.088426 & -2.002660 & -0.180623 \\ \mathrm{C} & 4.395738 & -2.633049 & -0.231020 \\ \mathrm{C} & 4.929553 & -2.680077 & 1.192461 \\ \mathrm{C} & 4.205489 & -4.030155 & -0.801223 \\ \mathrm{C} & 5.277579 & -1.781191 & -1.130874 \\ \mathrm{H} & 4.265467 & -3.262793 & 1.838473 \\ \mathrm{H} & 5.916418 & -3.153405 & 1.186910 \\ \mathrm{H} & 5.027796 & -1.671246 & 1.605384 \\ \mathrm{H} & 3.786780 & -3.985477 & -1.811155 \\ \mathrm{H} & 5.178699 & -4.528636 & -0.848051 \\ & 3.539648 & -4.623068 & -0.166846 \\ \mathrm{H} & 4.271542 & -2.235935 & -1.186822 \\ \mathrm{H} & 5.379784 & -0.767762 & -0.730500\end{array}$

IM2 M06/6-311g(d,p)/superfine in PhCF3 Solvent Electronic energy -7035.615512 a.u.

Gibbs free energy -7035.233603 (-7035.228792) a.u. 60

$\begin{array}{llll}\mathrm{Ti} & 0.222248 & -0.464574 & 0.007555 \\ \mathrm{~N} & 2.135565 & -0.443168 & -0.064244 \\ \mathrm{C} & 3.317011 & -1.172428 & -0.094675 \\ \mathrm{C} & 3.250483 & -2.569557 & -0.101057 \\ \mathrm{C} & 4.412684 & -3.320629 & -0.130955 \\ \mathrm{C} & 4.563027 & -0.538939 & -0.118505 \\ \mathrm{C} & 5.719660 & -1.303736 & -0.148574 \\ \mathrm{C} & 5.653223 & -2.691639 & -0.155189 \\ \mathrm{H} & 2.277158 & -3.055537 & -0.079464 \\ \mathrm{H} & 4.351700 & -4.405081 & -0.134953 \\ \mathrm{H} & 6.685932 & -0.807431 & -0.167054 \\ \mathrm{H} & 6.563953 & -3.282413 & -0.178525\end{array}$

\begin{tabular}{|c|c|c|}
\hline 4.595875 & 0.545392 & -0.111182 \\
\hline 1.875588 & 0.856038 & 0.001448 \\
\hline 2.618545 & 1.882361 & 0.035093 \\
\hline 2.103215 & 3.254153 & 0.146596 \\
\hline 3.326911 & 4.159781 & 0.230934 \\
\hline 3.933210 & 3.903742 & 1.107478 \\
\hline 3.953520 & 4.040851 & -0.660483 \\
\hline 3.032159 & 5.213221 & 0.309269 \\
\hline 1.280715 & 3.426414 & 1.419314 \\
\hline 0.385306 & 2.797890 & 1.416389 \\
\hline 1.881431 & 3.147442 & 2.293438 \\
\hline 0.966471 & 4.470833 & 1.541291 \\
\hline 1.303080 & 3.628775 & -1.096698 \\
\hline 1.929397 & 3.526707 & -1.990887 \\
\hline 0.429730 & 2.982769 & -1.227216 \\
\hline 0.959038 & 4.669761 & -1.039750 \\
\hline-0.049943 & -0.997999 & -2.385505 \\
\hline 0.110025 & -0.998306 & 2.407898 \\
\hline-1.861588 & -1.389549 & 0.071566 \\
\hline-2.894001 & -1.914516 & 0.091690 \\
\hline-4.171387 & -2.605970 & 0.099756 \\
\hline-4.835315 & -2.354237 & -1.245082 \\
\hline-3.881933 & -4.085250 & 0.306091 \\
\hline-4.994740 & -2.038133 & 1.245163 \\
\hline-4.211631 & -2.727847 & -2.063306 \\
\hline-5.795944 & -2.878166 & -1.270946 \\
\hline-5.016792 & -1.285903 & -1.398529 \\
\hline-3.370020 & -4.253407 & 1.258529 \\
\hline-4.829047 & -4.633601 & 0.316738 \\
\hline-3.260565 & -4.477334 & -0.504879 \\
\hline-5.962225 & -2.549111 & 1.273879 \\
\hline-4.489114 & -2.194127 & 2.203124 \\
\hline-5.170796 & -0.966799 & 1.107824 \\
\hline-1.070405 & 1.287100 & -0.022452 \\
\hline-1.843427 & 2.147784 & -0.069147 \\
\hline-2.838933 & 3.203329 & -0.140068 \\
\hline-4.168695 & 2.592248 & 0.274874 \\
\hline-2.410665 & 4.309200 & 0.811518 \\
\hline-2.875407 & 3.690928 & -1.580831 \\
\hline-4.120049 & 2.213973 & 1.300807 \\
\hline-4.946242 & 3.360623 & 0.222083 \\
\hline-4.442705 & 1.770477 & -0.394542 \\
\hline-1.445194 & 4.730236 & 0.513947 \\
\hline-3.160974 & 5.105632 & 0.785415 \\
\hline-2.334090 & 3.935903 & 1.837612 \\
\hline-3.625085 & 4.483866 & -1.664813 \\
\hline-1.904641 & 4.095832 & -1.882909 \\
\hline-3.148062 & 2.878294 & -2.261123 \\
\hline
\end{tabular}

TS2 M06/6-311g(d,p)/superfine in PhCF3 Solvent Electronic energy -7035.599735 a.u. Gibbs free energy -7035.220300 (-7035.215649) a.u.

$\begin{array}{llll}60 & & & \\ \mathrm{Ti} & 0.004733 & -0.522487 & -0.039939 \\ \mathrm{~N} & 2.047797 & -0.518426 & -0.343905 \\ \mathrm{C} & 3.088046 & -1.464926 & -0.257737 \\ \mathrm{C} & 2.752068 & -2.815958 & -0.198689 \\ \mathrm{C} & 3.749982 & -3.774299 & -0.123913 \\ \mathrm{C} & 4.427533 & -1.079998 & -0.241859 \\ \mathrm{C} & 5.418321 & -2.047566 & -0.167349 \\ \mathrm{C} & 5.086930 & -3.395402 & -0.108078 \\ \mathrm{H} & 1.705449 & -3.111330 & -0.215610 \\ \mathrm{H} & 3.480478 & -4.825276 & -0.078452 \\ \mathrm{H} & 6.460734 & -1.742798 & -0.156383 \\ \mathrm{H} & 5.867196 & -4.147918 & -0.049476 \\ \mathrm{H} & 4.686135 & -0.026067 & -0.290874\end{array}$




$\begin{array}{lrrr}\mathrm{C} & 2.168823 & 0.741807 & -0.240193 \\ \mathrm{~N} & 2.766459 & 1.795976 & -0.268346 \\ \mathrm{C} & 2.652022 & 3.172350 & 0.213737 \\ \mathrm{C} & 4.075897 & 3.655855 & 0.460592 \\ \mathrm{H} & 4.567360 & 3.039093 & 1.220899 \\ \mathrm{H} & 4.666247 & 3.606386 & -0.460589 \\ \mathrm{H} & 4.063508 & 4.693693 & 0.810866 \\ \mathrm{C} & 1.854213 & 3.226327 & 1.508017 \\ \mathrm{H} & 0.830264 & 2.871268 & 1.361189 \\ \mathrm{H} & 2.328598 & 2.611696 & 2.281152 \\ \mathrm{H} & 1.811637 & 4.260540 & 1.869121 \\ \mathrm{C} & 2.002386 & 4.017317 & -0.874687 \\ \mathrm{H} & 2.577597 & 3.955631 & -1.804618 \\ \mathrm{H} & 0.979685 & 3.681698 & -1.071604 \\ \mathrm{H} & 1.972173 & 5.066385 & -0.557300 \\ \mathrm{Br} & -0.405065 & -1.379871 & -2.318528 \\ \mathrm{Br} & 0.223838 & -0.824113 & 2.386804 \\ \mathrm{C} & -0.667233 & 1.365497 & -0.245653 \\ \mathrm{~N} & -1.061385 & 2.478926 & -0.379473 \\ \mathrm{C} & -2.294728 & 3.272826 & -0.400859 \\ \mathrm{C} & -3.472920 & 2.367018 & -0.079418 \\ \mathrm{C} & -2.134337 & 4.367644 & 0.641924 \\ \mathrm{C} & -2.417657 & 3.865888 & -1.795472 \\ \mathrm{H} & -3.353465 & 1.916416 & 0.912594 \\ \mathrm{H} & -4.403323 & 2.945657 & -0.089851 \\ \mathrm{H} & -3.552850 & 1.563232 & -0.821189 \\ \mathrm{H} & -1.262287 & 4.992147 & 0.418207 \\ \mathrm{H} & -3.026345 & 5.003045 & 0.646431 \\ \mathrm{H} & -2.009418 & 3.937959 & 1.641786 \\ \mathrm{H} & -3.321053 & 4.482605 & -1.849452 \\ \mathrm{H} & -1.552508 & 4.494804 & -2.030138 \\ \mathrm{H} & -2.490348 & 3.074911 & -2.549277 \\ \mathrm{C} & -2.087156 & -1.106224 & 0.260147 \\ \mathrm{~N} & -3.198666 & -1.431930 & 0.360402 \\ \mathrm{C} & -4.576325 & -1.877813 & 0.405088 \\ \mathrm{H} & -4.617575 & -3.174598 & 1.199862 \\ \mathrm{H} & -4.400761 & -2.855855 & -1.521356 \\ \mathrm{C} & -5.402567 & -0.792899 & 1.079865 \\ \mathrm{C} & -5.020937 & -2.096751 & -1.033945 \\ \mathrm{H} & -4.263819 & -3.015529 & 2.223284 \\ \mathrm{H} & -5.649255 & -3.538363 & 1.239868 \\ \mathrm{H} & -3.995266 & -3.940321 & 0.726471 \\ \mathrm{H} & -5.374863 & 0.137145 & 0.503071 \\ \mathrm{H} & -6.442623 & -1.127418 & 1.149056 \\ \mathrm{H} & -5.033118 & -0.593792 & 2.090934 \\ \mathrm{H} & -6.061325 & -2.437247 & -1.040843 \\ \mathrm{H} & & & -1.607968 \\ \mathrm{H} & & \end{array}$

$\begin{array}{lrrr}\mathrm{H} & 2.123861 & -3.693665 & 1.701993 \\ \mathrm{H} & 4.084467 & -3.140593 & -1.459800 \\ \mathrm{H} & 2.392657 & -3.179883 & -2.004135 \\ \mathrm{H} & 3.262177 & -1.628797 & -1.906536 \\ \mathrm{C} & -0.182484 & 1.651045 & -0.049814 \\ \mathrm{~N} & 0.481282 & 2.653697 & -0.056010 \\ \mathrm{C} & 1.951070 & 2.864562 & -0.044568 \\ \mathrm{C} & 2.213539 & 4.321709 & -0.375250 \\ \mathrm{C} & 2.434702 & 2.527724 & 1.358131 \\ \mathrm{C} & 2.588205 & 1.946328 & -1.075566 \\ \mathrm{H} & 1.728747 & 4.977255 & 0.355780 \\ \mathrm{H} & 3.290249 & 4.522648 & -0.362669 \\ \mathrm{H} & 1.827710 & 4.568703 & -1.370135 \\ \mathrm{H} & 2.229603 & 1.477875 & 1.596633 \\ \mathrm{H} & 3.514922 & 2.699389 & 1.425323 \\ \mathrm{H} & 1.937718 & 3.157155 & 2.103898 \\ \mathrm{H} & 3.672935 & 2.102474 & -1.089127 \\ \mathrm{H} & 2.388640 & 0.895975 & -0.835567 \\ \mathrm{H} & 2.196642 & 2.154859 & -2.077148\end{array}$

IM3 M06/6-311g(d,p)/superfine in PhCF3 Solvent Electronic energy -6498.730864 a.u.

Gibbs free energy -6498.548946 (-6498.546781) a.u.

$\begin{array}{lrrr}33 & & & \\ \mathrm{Br} & -2.387236 & -0.316541 & -2.100785 \\ \mathrm{Br} & -2.325307 & -0.226679 & 2.136710 \\ \mathrm{Ti} & -1.301782 & 0.024777 & -0.003699 \\ \mathrm{C} & 0.445307 & -1.120509 & 0.003200 \\ \mathrm{~N} & 1.425718 & -1.753353 & 0.008201 \\ \mathrm{C} & 2.692278 & -2.454646 & 0.017542 \\ \mathrm{C} & 3.685485 & -1.612387 & 0.806274 \\ \mathrm{C} & 2.475304 & -3.810871 & 0.672111 \\ \mathrm{C} & 3.129332 & -2.606661 & -1.433047 \\ \mathrm{H} & 3.341313 & -1.466521 & 1.835211 \\ \mathrm{H} & 4.650356 & -2.129019 & 0.832868 \\ \mathrm{H} & 3.827184 & -0.632969 & 0.336968 \\ \mathrm{H} & 1.740716 & -4.398742 & 0.113244 \\ \mathrm{H} & 3.422866 & -4.358718 & 0.687774\end{array}$




\section{$\mathrm{L}=$ single pyridine (red)}

IM0 M06/6-311g(d,p)/superfine in PhCF3 Solvent Electronic energy -6532.097299 a.u.

Gibbs free energy -6531.983527 (-6531.980787) a.u. 26

$\begin{array}{lrrr}\mathrm{Ti} & -0.401580 & -0.515321 & 0.060836 \\ \mathrm{~N} & -1.544345 & 1.252559 & -0.139602 \\ \mathrm{~N} & 1.171130 & 0.059484 & 0.109770 \\ \mathrm{C} & 2.503822 & 0.389319 & 0.077142 \\ \mathrm{C} & 3.392037 & -0.308520 & -0.754765 \\ \mathrm{C} & 4.733269 & 0.034648 & -0.789265 \\ \mathrm{C} & 2.999130 & 1.435978 & 0.868984 \\ \mathrm{C} & 4.342371 & 1.773227 & 0.822389 \\ \mathrm{C} & 5.216343 & 1.076639 & -0.004576 \\ \mathrm{H} & 3.004362 & -1.119573 & -1.365544 \\ \mathrm{H} & 5.410033 & -0.516056 & -1.436754 \\ \mathrm{H} & 4.712066 & 2.586363 & 1.441009 \\ \mathrm{H} & 6.268597 & 1.342183 & -0.035904 \\ \mathrm{H} & 2.310923 & 1.968364 & 1.520296 \\ \mathrm{C} & -0.990406 & 2.471058 & -0.264027 \\ \mathrm{C} & -2.884833 & 1.139327 & -0.149064 \\ \mathrm{C} & -1.758732 & 3.609479 & -0.399861 \\ \mathrm{C} & -3.714199 & 2.232817 & -0.277907 \\ \mathrm{C} & -3.140253 & 3.489835 & -0.405416 \\ \mathrm{H} & 0.093445 & 2.509787 & -0.253331 \\ \mathrm{H} & -1.274423 & 4.573579 & -0.498894 \\ \mathrm{H} & -3.766597 & 4.369796 & -0.508883 \\ \mathrm{H} & -4.788709 & 2.095602 & -0.278778 \\ \mathrm{H} & -3.295771 & 0.136757 & -0.049204 \\ \mathrm{Br} & -1.015602 & -1.567392 & 2.139195 \\ \mathrm{Br} & -0.739196 & -1.857091 & -1.910777 \\ & & & \\ & & & \end{array}$

IM1 M06/6-311g(d,p)/superfine in PhCF3 Solvent Electronic energy -6782.677960 a.u.

Gibbs free energy -6782.451988 (-6782.447471) a.u.

$\begin{array}{lrrr}41 & & & \\ \mathrm{Ti} & 0.524201 & -0.398118 & -0.017846 \\ \mathrm{~N} & 2.716130 & -0.154363 & 0.058326 \\ \mathrm{~N} & 0.061537 & 1.215846 & -0.177378 \\ \mathrm{C} & -0.511562 & 2.459462 & -0.151508 \\ \mathrm{C} & -1.530495 & 2.749964 & 0.771246 \\ \mathrm{C} & -2.118048 & 4.003675 & 0.796600 \\ \mathrm{C} & -0.099811 & 3.466886 & -1.037935 \\ \mathrm{C} & -0.688625 & 4.720822 & -0.996416 \\ \mathrm{C} & -1.700326 & 4.997166 & -0.083562 \\ \mathrm{H} & -1.839819 & 1.968649 & 1.462107 \\ \mathrm{H} & -2.907097 & 4.211239 & 1.514388 \\ \mathrm{H} & -0.357129 & 5.490669 & -1.687969 \\ \mathrm{H} & -2.160824 & 5.980066 & -0.057770 \\ \mathrm{H} & 0.683143 & 3.240583 & -1.757017 \\ \mathrm{C} & 3.268894 & 1.062453 & -0.035645 \\ \mathrm{C} & 3.524173 & -1.216656 & 0.190456 \\ \mathrm{C} & 4.637675 & 1.258371 & -0.003124 \\ \mathrm{C} & 4.898965 & -1.104645 & 0.231057 \\ \mathrm{C} & 5.467531 & 0.157494 & 0.131346 \\ \mathrm{H} & 2.581096 & 1.895785 & -0.138507 \\ \mathrm{H} & 5.037614 & 2.262584 & -0.082977 \\ \mathrm{H} & 6.545502 & 0.279717 & 0.159273 \\ \mathrm{H} & 5.508701 & -1.994129 & 0.338554 \\ \mathrm{H} & 3.043946 & -2.189073 & 0.265746 \\ \mathrm{C} & -1.635593 & -0.999969 & -0.045415 \\ \mathrm{~N} & -2.778966 & -1.179315 & -0.059527 \\ \mathrm{C} & -4.216084 & -1.386468 & -0.077102 \\ \mathrm{C} & -4.863331 & -0.103053 & 0.421051 \\ \mathrm{H} & -4.543669 & 0.123392 & 1.443077\end{array}$

$\begin{array}{lrrr}\mathrm{H} & -4.604026 & 0.740634 & -0.226155 \\ \mathrm{H} & -5.950692 & -0.227913 & 0.414942 \\ \mathrm{C} & -4.520440 & -2.557636 & 0.844130 \\ \mathrm{H} & -4.020962 & -3.467022 & 0.496286 \\ \mathrm{H} & -4.195317 & -2.344274 & 1.867053 \\ \mathrm{H} & -5.600778 & -2.733097 & 0.850225 \\ \mathrm{C} & -4.615330 & -1.689469 & -1.513100 \\ \mathrm{H} & -4.362028 & -0.853683 & -2.172386 \\ \mathrm{H} & -4.112570 & -2.591442 & -1.875428 \\ \mathrm{H} & -5.696948 & -1.852089 & -1.553717 \\ \mathrm{Br} & 0.728717 & -1.571110 & -2.185734 \\ \mathrm{Br} & 0.518225 & -1.093678 & 2.349461\end{array}$

TS1 M06/6-311g(d,p)/superfine in PhCF3 Solvent Electronic energy -6782.636650 a.u.

Gibbs free energy -6782.410856 (-6782.405852) a.u. 41

$\begin{array}{lll}0.535191 & -0.557900 & -0.091059\end{array}$

$\begin{array}{llll}\mathrm{N} & 2.562348 & 0.363926 & 0.193242\end{array}$

$\begin{array}{llll}\mathrm{N} & -0.465618 & 0.880878 & 0.092786\end{array}$

$\begin{array}{llll}\text { C } & -1.096569 & 2.111334 & 0.120670\end{array}$

$\begin{array}{llll}\mathrm{C} & -1.830539 & 2.517991 & 1.239494\end{array}$

$\begin{array}{llll}\mathrm{C} & -2.445603 & 3.759859 & 1.245381\end{array}$

$\begin{array}{llll}\mathrm{C} & -1.002627 & 2.956440 & -0.990316\end{array}$

$\begin{array}{llll}\text { C } & -1.622548 & 4.195464 & -0.972800\end{array}$

$\begin{array}{llll}\mathrm{C} & -2.344792 & 4.601668 & 0.143606\end{array}$

$\begin{array}{llll}\mathrm{C} & -2.344792 & 4.601668 & 0.143606 \\ \mathrm{H} & -1.900526 & 1.854355 & 2.095899\end{array}$

$\begin{array}{llll}\mathrm{H} & -3.010007 & 4.073619 & 2.118718\end{array}$

$\begin{array}{llll}\mathrm{H} & -1.542588 & 4.848411 & -1.837037\end{array}$

$\begin{array}{llll}\mathrm{H} & -2.829213 & 5.573287 & 0.154792\end{array}$

$\begin{array}{llll}\mathrm{H} & -0.436359 & 2.620113 & -1.855260\end{array}$

$\begin{array}{llll}\mathrm{C} & 2.666265 & 1.697261 & 0.275312\end{array}$

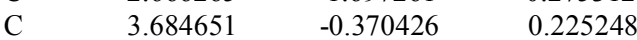

$\begin{array}{llll}\text { C } & 3.884216 & 2.339490 & 0.398975\end{array}$

$\begin{array}{llll}\text { C } & 4.938028 & 0.195287 & 0.341285\end{array}$

$\begin{array}{llll}\text { C } & 5.040087 & 1.576269 & 0.432783\end{array}$

$\begin{array}{llll}\mathrm{H} & 1.737385 & 2.259877 & 0.242091\end{array}$

$\begin{array}{llll}\mathrm{H} & 3.917185 & 3.420606 & 0.466994\end{array}$

$\begin{array}{llll}\mathrm{H} & 6.011197 & 2.050893 & 0.529315\end{array}$

$\begin{array}{llll}\mathrm{H} & 5.815696 & -0.440199 & 0.361414\end{array}$

$\begin{array}{llll}\mathrm{H} & 3.565948 & -1.448873 & 0.156451\end{array}$

$\begin{array}{llll}\mathrm{C} & -1.469452 & -0.491964 & -0.001660\end{array}$

$\begin{array}{llll}\mathrm{N} & -2.675150 & -0.299449 & 0.087739\end{array}$

$\begin{array}{llll}\text { C } & -3.680590 & -1.381087 & 0.032678\end{array}$

$\begin{array}{llll}\mathrm{C} & -4.234579 & -1.517586 & 1.444095\end{array}$

$\begin{array}{llll}\mathrm{H} & -3.449405 & -1.843664 & 2.136417\end{array}$

$\begin{array}{llll}\mathrm{H} & -4.631563 & -0.560166 & 1.798602\end{array}$

$\begin{array}{llll}\mathrm{H} & -4.631563 & -0.560166 & 1.798602 \\ \mathrm{C} & -5.042300 & -2.258189 & 1.463360\end{array}$

$\begin{array}{llll}\text { C } & -3.101751 & -2.705691 & -0.440227\end{array}$

$\begin{array}{llll}\mathrm{C} & -3.101751 & -2.705691 & -0.440227 \\ \mathrm{H} & -2.664412 & -2.609578 & -1.440980\end{array}$

$\begin{array}{llll}\mathrm{H} & -2.323520 & -3.068153 & 0.240737\end{array}$

$\begin{array}{llll}\mathrm{H} & -3.893828 & -3.461766 & -0.485221\end{array}$

$\begin{array}{llll}\text { C } & -4.769458 & -0.910811 & -0.919814\end{array}$

$\begin{array}{llll}\mathrm{H} & -5.183265 & 0.047540 & -0.588632\end{array}$

$\begin{array}{llll}H & -4.367735 & -0.780244 & -1.930988\end{array}$

$\begin{array}{llll}\mathrm{H} & -5.580518 & -1.646574 & -0.963403\end{array}$

$\mathrm{Br} \quad 0.914454 \quad-1.250732 \quad-2.351650$

$\begin{array}{llll}\mathrm{Br} & 0.868235 & -2.018295 & 1.816662\end{array}$

IM2 M06/6-311g(d,p)/superfine in PhCF3 Solvent Electronic energy -6782.663899 a.u.

Gibbs free energy -6782.430594 (-6782.428064) a.u. 41

$\begin{array}{llll}\mathrm{Ti} & -0.166489 & -0.776806 & 0.196707 \\ \mathrm{~N} & -2.209371 & -0.444562 & -0.365746 \\ \mathrm{~N} & 1.344275 & 0.300252 & -0.129552\end{array}$




$\begin{array}{lrrr}\mathrm{C} & 2.723889 & 0.408325 & -0.290966 \\ \mathrm{C} & 3.517426 & -0.733240 & -0.147271 \\ \mathrm{C} & 4.889692 & -0.647190 & -0.305596 \\ \mathrm{C} & 3.320147 & 1.637181 & -0.588029 \\ \mathrm{C} & 4.696437 & 1.708603 & -0.744337 \\ \mathrm{C} & 5.485319 & 0.573356 & -0.606318 \\ \mathrm{H} & 3.045208 & -1.682534 & 0.092998 \\ \mathrm{H} & 5.500264 & -1.538158 & -0.191915 \\ \mathrm{H} & 5.157554 & 2.664610 & -0.975699 \\ \mathrm{H} & 6.562093 & 0.638243 & -0.730067 \\ \mathrm{H} & 2.689610 & 2.514186 & -0.683255 \\ \mathrm{C} & -3.209785 & -0.824613 & 0.445258 \\ \mathrm{C} & -2.512401 & 0.107170 & -1.553095 \\ \mathrm{C} & -4.537857 & -0.648632 & 0.108247 \\ \mathrm{C} & -3.814420 & 0.306611 & -1.960697 \\ \mathrm{C} & -4.846389 & -0.071404 & -1.112928 \\ \mathrm{H} & -2.932738 & -1.274868 & 1.394238 \\ \mathrm{H} & -5.311067 & -0.962968 & 0.798848 \\ \mathrm{H} & -5.880536 & 0.081827 & -1.403281 \\ \mathrm{H} & -4.009954 & 0.758230 & -2.926068 \\ \mathrm{H} & -1.677259 & 0.406428 & -2.180528 \\ \mathrm{C} & 0.350843 & 1.203506 & -0.008474 \\ \mathrm{~N} & 0.372581 & 2.471786 & -0.037132 \\ \mathrm{C} & -0.797903 & 3.316471 & 0.233653 \\ \mathrm{C} & -0.271322 & 4.508667 & 1.028002 \\ \mathrm{H} & 0.128137 & 4.178035 & 1.994130 \\ \mathrm{H} & 0.536406 & 5.007229 & 0.480760 \\ \mathrm{H} & -1.067922 & 5.238608 & 1.215071 \\ \mathrm{C} & -1.904528 & 2.642028 & 1.036284 \\ \mathrm{H} & -2.438301 & 1.892379 & 0.446660 \\ \mathrm{H} & -1.502162 & 2.156443 & 1.934564 \\ \mathrm{H} & -2.638605 & 3.390119 & 1.358451 \\ \mathrm{C} & -1.348524 & 3.804603 & -1.102172 \\ \mathrm{H} & -0.563987 & 4.305153 & -1.680940 \\ \mathrm{H} & -1.725982 & 2.963895 & -1.696851 \\ \mathrm{H} & -2.171198 & 4.514421 & -0.950862 \\ \mathrm{Br} & 0.221180 & -2.506537 & -1.435984 \\ \mathrm{Br} & -0.079264 & -1.442107 & 2.479237 \\ & & & \\ & & & \\ \mathrm{H} & & & \end{array}$

TS2 M06/6-311g(,p)/superfine in PhCF3 Solvent N/A (could not be optimized)

IM3 M06/6-311g(d,p)/superfine in PhCF3 Solvent Electronic energy -6245.729651 a.u.

Gibbs free energy -6245.695176 (-6245.695013) a.u.

$\begin{array}{lrrr}14 & & & \\ \mathrm{~N} & 1.548900 & -0.013973 & 0.048069 \\ \mathrm{C} & 2.265372 & 1.145185 & 0.017387 \\ \mathrm{C} & 2.252679 & -1.179165 & -0.011167 \\ \mathrm{C} & 3.636900 & 1.169105 & -0.095100 \\ \mathrm{C} & 3.623863 & -1.214172 & -0.123460 \\ \mathrm{C} & 4.345417 & -0.025397 & -0.173677 \\ \mathrm{H} & 1.694303 & 2.069127 & 0.068123 \\ \mathrm{H} & 4.143827 & 2.128000 & -0.124540 \\ \mathrm{H} & 5.425354 & -0.029956 & -0.269528 \\ \mathrm{H} & 4.120648 & -2.177120 & -0.175168 \\ \mathrm{H} & 1.671535 & -2.097755 & 0.018652 \\ \mathrm{Br} & -1.624004 & 1.961290 & -0.144719 \\ \mathrm{Br} & -1.679981 & -1.936301 & -0.136922 \\ \mathrm{Ti} & -0.409267 & -0.001929 & 0.559978\end{array}$




\section{$\mathrm{L}=$ single isocyanide (gray)}

IM0 M06/6-311g(d,p)/superfine in PhCF3 Solvent Electronic energy -6534.467205 a.u.

Gibbs free energy -6534.316149 (-6534.313672) a.u. 30

$\begin{array}{lrrr}\mathrm{Ti} & 0.741502 & -0.597533 & -0.235190 \\ \mathrm{~N} & 0.910923 & 1.063855 & -0.269245 \\ \mathrm{C} & 1.017543 & 2.418433 & -0.076685 \\ \mathrm{C} & 1.931743 & 3.179867 & -0.817622 \\ \mathrm{C} & 2.026266 & 4.546656 & -0.612237 \\ \mathrm{C} & 0.202779 & 3.059646 & 0.868222 \\ \mathrm{C} & 0.304910 & 4.426865 & 1.062826 \\ \mathrm{C} & 1.215439 & 5.176620 & 0.325474 \\ \mathrm{H} & 2.561338 & 2.676565 & -1.546039 \\ \mathrm{H} & 2.740290 & 5.127084 & -1.189708 \\ \mathrm{H} & -0.329783 & 4.913312 & 1.798217 \\ \mathrm{H} & 1.293582 & 6.248105 & 0.482390 \\ \mathrm{H} & -0.501257 & 2.459917 & 1.440175 \\ \mathrm{Br} & 0.490744 & -1.145655 & 2.100659 \\ \mathrm{Br} & 2.885664 & -1.588070 & -0.935546 \\ \mathrm{C} & -1.495280 & -0.473760 & -0.568643 \\ \mathrm{~N} & -2.628719 & -0.251610 & -0.560935 \\ \mathrm{C} & -4.047121 & 0.062010 & -0.473767 \\ \mathrm{C} & -4.808059 & -1.253939 & -0.481319 \\ \mathrm{C} & -4.247984 & 0.817309 & 0.831889 \\ \mathrm{C} & -4.399611 & 0.922353 & -1.676448 \\ \mathrm{H} & -4.519114 & -1.876614 & 0.370746 \\ \mathrm{H} & -5.879199 & -1.041283 & -0.410842 \\ \mathrm{H} & -4.622452 & -1.807713 & -1.406607 \\ \mathrm{H} & -3.670084 & 1.746565 & 0.837391 \\ \mathrm{H} & -5.309191 & 1.064000 & 0.935493 \\ \mathrm{H} & -3.945990 & 0.205285 & 1.687475 \\ \mathrm{H} & -5.462343 & 1.178401 & -1.625172 \\ \mathrm{H} & -3.816682 & 1.848304 & -1.677931 \\ \mathrm{H} & -4.215271 & 0.383675 & -2.610863 \\ & & & \end{array}$

IM1 M06/6-311g(d,p)/superfine in PhCF3 Solvent Electronic energy -6785.055559 a.u.

Gibbs free energy -6784.795323 (-6784.789938) a.u. 45

$\begin{array}{lrrr}\mathrm{Ti} & 0.201706 & -0.490558 & -0.025545 \\ \mathrm{~N} & -0.153629 & 1.148399 & -0.204576 \\ \mathrm{C} & -0.637508 & 2.429462 & -0.189451 \\ \mathrm{C} & -1.611960 & 2.800591 & 0.752094 \\ \mathrm{C} & -2.120715 & 4.088442 & 0.764742 \\ \mathrm{C} & -0.186296 & 3.390309 & -1.106900 \\ \mathrm{C} & -0.694627 & 4.678939 & -1.077211 \\ \mathrm{C} & -1.664639 & 5.035465 & -0.146715 \\ \mathrm{H} & -1.951097 & 2.053217 & 1.466196 \\ \mathrm{H} & -2.876874 & 4.359264 & 1.496610 \\ \mathrm{H} & -0.332994 & 5.413216 & -1.791890 \\ \mathrm{H} & -2.062300 & 6.045643 & -0.130960 \\ \mathrm{H} & 0.566235 & 3.101723 & -1.835376 \\ \mathrm{C} & -1.985917 & -0.993321 & -0.038473 \\ \mathrm{~N} & -3.138288 & -1.096170 & -0.039114 \\ \mathrm{C} & -4.587998 & -1.189102 & -0.038104 \\ \mathrm{C} & -5.124298 & 0.175293 & 0.368794 \\ \mathrm{H} & -4.782541 & 0.444342 & 1.373173 \\ \mathrm{H} & -4.798384 & 0.947798 & -0.334691 \\ \mathrm{H} & -6.218302 & 0.140606 & 0.369751 \\ \mathrm{C} & -4.977476 & -2.262776 & 0.965801 \\ \mathrm{H} & -4.556367 & -3.232427 & 0.683177 \\ \mathrm{H} & -4.627790 & -2.003589 & 1.969824 \\ \mathrm{H} & -6.068372 & -2.348613 & 0.987102 \\ \mathrm{C} & -5.021903 & -1.560202 & -1.447699 \\ & & & \end{array}$

$\begin{array}{lrrr}\mathrm{H} & -4.706598 & -0.797447 & -2.166079 \\ \mathrm{H} & -4.598196 & -2.524234 & -1.745303 \\ \mathrm{H} & -6.113511 & -1.635349 & -1.473509 \\ \mathrm{Br} & 0.440276 & -1.665262 & -2.177671 \\ \mathrm{Br} & 0.245180 & -1.122293 & 2.350136 \\ \mathrm{C} & 2.448422 & -0.311046 & 0.049710 \\ \mathrm{~N} & 3.596666 & -0.175635 & 0.076022 \\ \mathrm{C} & 5.039169 & -0.001427 & 0.104319 \\ \mathrm{C} & 5.658870 & -1.372878 & 0.323671 \\ \mathrm{C} & 5.450541 & 0.587774 & -1.236183 \\ \mathrm{C} & 5.359948 & 0.944908 & 1.250876 \\ \mathrm{H} & 5.391866 & -2.056076 & -0.488293 \\ \mathrm{H} & 6.748020 & -1.268551 & 0.348607 \\ \mathrm{H} & 5.327384 & -1.803445 & 1.273446 \\ \mathrm{H} & 4.968977 & 1.556584 & -1.400318 \\ \mathrm{H} & 6.535505 & 0.731648 & -1.241349 \\ \mathrm{H} & 5.183016 & -0.084774 & -2.056851 \\ \mathrm{H} & 6.443287 & 1.094779 & 1.293078 \\ \mathrm{H} & 4.878321 & 1.915978 & 1.101261 \\ \mathrm{H} & 5.027273 & 0.527644 & 2.206145\end{array}$

TS1 M06/6-311g(d,p)/superfine in PhCF3 Solvent Electronic energy -6785.010969 a.u. Gibbs free energy -6784.747499 (-6784.743155) a.u. 45

$\mathrm{N}$

C

$\mathrm{C}$

C

C

C

$\mathrm{C}$
$\mathrm{H}$

$\mathrm{H}$

$\mathrm{H}$

$\mathrm{H}$

$\mathrm{C}$

$\mathrm{N}$

$\mathrm{C}$
$\mathrm{C}$

C

$\mathrm{H}$

H

$\mathrm{C}$
$\mathrm{H}$

$\mathrm{H}$
$\mathrm{H}$

$\mathrm{C}$
$\mathrm{H}$

$\mathrm{H}$
$\mathrm{H}$

$\mathrm{H}$

$\mathrm{Br}$
$\mathrm{Br}$

$\mathrm{Br}$

C

0.320394

$-1.105969$

$-2.090212$

$-2.225683$

$-3.183053$

$-2.931923$

$-3.885313$

$-4.014736$

$-1.568979$

$-3.280168$

$-4.531861$

$-4.762625$

$-2.817340$

$-1.605834$

$-2.803101$

$-3.411275$

$-4.514458$

$-4.097342$

$-5.235707$

$-5.044480$

$-2.404947$

$-1.602935$

$-1.951738$

$-2.905353$

$-4.003060$

$-4.708912$

$-3.211746$

$-4.534182$

0.497449

0.939733

2.587007

3.733912

5.181428

5.750375

5.517048

5.626328

5.389754

6.841757

5.474202

5.068035

6.603818

$\begin{array}{cc}-0.056055 & 0.054341 \\ 0.966738 & 0.233295 \\ 1.945914 & 0.184942 \\ 2.837782 & 1.249913 \\ 3.839231 & 1.194402 \\ 2.055062 & -0.926000 \\ 3.059174 & -0.969455 \\ 3.953729 & 0.087378 \\ 2.734310 & 2.108625 \\ 4.534510 & 2.023079 \\ 3.146073 & -1.837815 \\ 4.739783 & 0.046404 \\ 1.356625 & -1.750740 \\ -0.596326 & 0.164191 \\ -0.840402 & 0.192807 \\ -2.171241 & 0.015890 \\ -2.293821 & 1.055431 \\ -2.254521 & 2.067978 \\ -1.476517 & 0.949213 \\ -3.245679 & 0.937475 \\ -3.299844 & 0.175193 \\ -3.227556 & -0.568133 \\ -3.282343 & 1.172915 \\ -4.265968 & 0.043635 \\ -2.175013 & -1.387622 \\ -1.345936 & -1.510760 \\ -2.068269 & -2.139342 \\ -3.115572 & -1.573661 \\ -0.702967 & -2.295843 \\ -1.095542 & 2.184007 \\ 0.362789 & -0.092836 \\ 0.503857 & -0.122249 \\ 0.643267 & -0.119369 \\ -0.560415 & -0.855011 \\ 1.943388 & -0.832606 \\ 0.669919 & 1.334758 \\ -0.594043 & -1.887487 \\ -0.480861 & -0.868198 \\ -1.491782 & -0.351463 \\ 2.798487 & -0.318308 \\ 2.071840 & -0.838974\end{array}$




$\begin{array}{rrrr}\mathrm{H} & 5.161792 & 1.923826 & -1.867288 \\ \mathrm{H} & 6.716339 & 0.761909 & 1.369321 \\ \mathrm{H} & 5.186848 & 1.522141 & 1.861986 \\ \mathrm{H} & 5.336713 & -0.252359 & 1.848101\end{array}$

IM2 M06/6-311g(d,p)/superfine in PhCF3 Solvent Electronic energy -6785.042394 a.u.

Gibbs free energy -6784.777268 (-6784.772282) a.u. 45

$\begin{array}{lrrr}\mathrm{Ti} & 0.125619 & 0.815571 & -0.021635 \\ \mathrm{~N} & 1.678554 & -0.237191 & 0.017662 \\ \mathrm{C} & 3.072416 & -0.285758 & 0.035120 \\ \mathrm{C} & 3.790654 & 0.913435 & 0.035958 \\ \mathrm{C} & 5.174245 & 0.893293 & 0.053388 \\ \mathrm{C} & 3.755073 & -1.504579 & 0.051953 \\ \mathrm{C} & 5.142214 & -1.509942 & 0.069387 \\ \mathrm{C} & 5.856526 & -0.318740 & 0.070091 \\ \mathrm{H} & 3.253622 & 1.859016 & 0.023503 \\ \mathrm{H} & 5.725070 & 1.829152 & 0.053935 \\ \mathrm{H} & 5.670668 & -2.458900 & 0.082490 \\ \mathrm{H} & 6.942114 & -0.332766 & 0.083679 \\ \mathrm{H} & 3.181090 & -2.424308 & 0.050988 \\ \mathrm{C} & 0.714937 & -1.181057 & 0.007598 \\ \mathrm{~N} & 0.814724 & -2.443337 & 0.015860 \\ \mathrm{C} & -0.294332 & -3.398238 & -0.009566 \\ \mathrm{C} & -0.113771 & -4.241304 & -1.268625 \\ \mathrm{H} & -0.213412 & -3.618597 & -2.165606 \\ \mathrm{H} & 0.880173 & -4.701783 & -1.283500 \\ \mathrm{H} & -0.865890 & -5.037983 & -1.315418 \\ \mathrm{C} & -1.682548 & -2.781481 & -0.009747 \\ \mathrm{H} & -1.846818 & -2.175782 & 0.888679 \\ \mathrm{H} & -1.836849 & -2.151330 & -0.892904 \\ \mathrm{H} & -2.439350 & -3.575532 & -0.025185 \\ \mathrm{C} & -0.133504 & -4.283502 & 1.222676 \\ \mathrm{H} & 0.859826 & -4.745255 & 1.236918 \\ \mathrm{H} & -0.246151 & -3.691393 & 2.138615 \\ \mathrm{H} & -0.886686 & -5.080451 & 1.231335 \\ \mathrm{Br} & 0.134665 & 2.068933 & 2.000437 \\ \mathrm{Br} & 0.152940 & 1.974185 & -2.096750 \\ \mathrm{C} & -2.036913 & 0.360644 & 0.000684 \\ \mathrm{~N} & -3.182332 & 0.214946 & 0.019063 \\ \mathrm{C} & -4.621921 & 0.002754 & 0.047127 \\ \mathrm{C} & -4.932601 & -0.800723 & 1.300817 \\ \mathrm{C} & -5.280736 & 1.372762 & 0.082115 \\ \mathrm{C} & -4.989026 & -0.762865 & -1.214797 \\ \mathrm{H} & -4.622553 & -0.258889 & 2.199395 \\ \mathrm{H} & -6.013096 & -0.967482 & 1.349399 \\ \mathrm{H} & -4.431186 & -1.773088 & 1.279120 \\ \mathrm{H} & -5.018726 & 1.954834 & -0.806512 \\ \mathrm{H} & -6.366565 & 1.239151 & 0.104596 \\ \mathrm{H} & -4.978575 & 1.928809 & 0.974664 \\ \mathrm{H} & -6.070447 & -0.930538 & -1.218929 \\ \mathrm{H} & -4.720843 & -0.193385 & -2.109777 \\ \mathrm{H} & -4.486117 & -1.734272 & -1.245748 \\ & & & \end{array}$

TS2 M06/6-311g(d,p)/superfine in PhCF3 Solvent Electronic energy -6785.016383 a.u.

Gibbs free energy -6784.750577 (-6784.747100) a.u. 45

$\begin{array}{lrrr}\mathrm{Ti} & 0.120623 & -1.037159 & 0.125730 \\ \mathrm{~N} & 1.364617 & 0.463074 & -0.464824 \\ \mathrm{C} & 2.780760 & 0.607947 & -0.450552 \\ \mathrm{C} & 3.556978 & -0.527843 & -0.247412 \\ \mathrm{C} & 4.939035 & -0.425217 & -0.235464 \\ \mathrm{C} & 3.387214 & 1.845875 & -0.643856 \\ \mathrm{C} & 4.771014 & 1.937444 & -0.630464\end{array}$

$\begin{array}{lrrr}\mathrm{C} & 5.551395 & 0.806723 & -0.426321 \\ \mathrm{H} & 3.080209 & -1.494747 & -0.103685 \\ \mathrm{H} & 5.539435 & -1.315685 & -0.076932 \\ \mathrm{H} & 5.241990 & 2.903936 & -0.782548 \\ \mathrm{H} & 6.633914 & 0.885273 & -0.416574 \\ \mathrm{H} & 2.779317 & 2.731381 & -0.807602 \\ \mathrm{C} & 0.549997 & 1.441535 & -0.450882 \\ \mathrm{~N} & 0.089404 & 2.536330 & -0.588477 \\ \mathrm{C} & -0.869635 & 3.485664 & -0.013017 \\ \mathrm{C} & -0.119525 & 4.801135 & 0.147503 \\ \mathrm{H} & 0.731893 & 4.681985 & 0.826480 \\ \mathrm{H} & 0.251854 & 5.156210 & -0.819444 \\ \mathrm{H} & -0.790849 & 5.560278 & 0.562794 \\ \mathrm{C} & -1.356712 & 2.981668 & 1.336581 \\ \mathrm{H} & -1.884227 & 2.028185 & 1.236402 \\ \mathrm{H} & -0.518673 & 2.850838 & 2.030429 \\ \mathrm{H} & -2.047503 & 3.714116 & 1.768757 \\ \mathrm{C} & -2.022208 & 3.649315 & -0.992330 \\ \mathrm{H} & -1.656428 & 3.988106 & -1.967182 \\ \mathrm{H} & -2.553905 & 2.701429 & -1.124478 \\ \mathrm{H} & -2.723325 & 4.398111 & -0.607312 \\ \mathrm{Br} & 0.414505 & -2.880387 & -1.369100 \\ \mathrm{Br} & 0.284131 & -1.307976 & 2.488768 \\ \mathrm{C} & -1.630123 & -0.249942 & -0.253422 \\ \mathrm{~N} & -2.704847 & 0.239354 & -0.492343 \\ \mathrm{C} & -4.081279 & -0.300505 & -0.430667 \\ \mathrm{C} & -4.062694 & -1.781803 & -0.097558 \\ \mathrm{C} & -4.797358 & 0.496532 & 0.649261 \\ \mathrm{C} & -4.710668 & -0.049925 & -1.791217 \\ \mathrm{H} & -3.577933 & -1.958979 & 0.869650 \\ \mathrm{H} & -5.086999 & -2.166389 & -0.046571 \\ \mathrm{H} & -3.518690 & -2.347114 & -0.863067 \\ \mathrm{H} & -4.779661 & 1.568073 & 0.420650 \\ \mathrm{H} & -5.841619 & 0.171920 & 0.714078 \\ \mathrm{H} & -4.324984 & 0.339567 & 1.625563 \\ \mathrm{H} & -5.748024 & -0.401674 & -1.787423 \\ \mathrm{H} & -4.706334 & 1.018639 & -2.031754 \\ \mathrm{H} & -4.166798 & -0.586191 & -2.576236 \\ & & & \end{array}$

IM3 M06/6-311g(d,p)/superfine in PhCF3 Solvent Electronic energy -6248.127500 a.u. Gibbs free energy -6248.056413 (-6248.055859) a.u. 18

$\begin{array}{lccc}\mathrm{Br} & 1.448482 & 2.071856 & 0.282626 \\ \mathrm{Br} & 1.609655 & -2.007105 & 0.278109 \\ \mathrm{Ti} & 1.035438 & 0.013524 & -0.900362 \\ \mathrm{C} & -0.887485 & -0.067255 & -1.032393 \\ \mathrm{~N} & -2.097724 & -0.098144 & -1.036949 \\ \mathrm{C} & -3.046669 & -0.067048 & 0.106264 \\ \mathrm{C} & -4.209579 & -0.974267 & -0.254872 \\ \mathrm{C} & -2.373432 & -0.528825 & 1.386685 \\ \mathrm{C} & -3.504816 & 1.379474 & 0.221588 \\ \mathrm{H} & -3.869092 & -2.006646 & -0.390468 \\ \mathrm{H} & -4.956698 & -0.961548 & 0.546121 \\ \mathrm{H} & -4.686725 & -0.642113 & -1.183107 \\ \mathrm{H} & -1.500982 & 0.091529 & 1.622208 \\ \mathrm{H} & -3.080452 & -0.464266 & 2.221157 \\ \mathrm{H} & -2.039507 & -1.569039 & 1.298074 \\ \mathrm{H} & -4.257136 & 1.467296 & 1.013274 \\ \mathrm{H} & -2.659956 & 2.032444 & 0.469005 \\ \mathrm{H} & -3.947930 & 1.723066 & -0.719005\end{array}$




\section{$\mathrm{L}=$ azobenzene (orange)}

IM0 M06/6-311g(d,p)/superfine in PhCF3 Solvent Electronic energy -6856.393736 a.u.

Gibbs free energy -6856.192516 (-6856.188816) a.u. 39

$\begin{array}{lrrr}\mathrm{Ti} & -0.656968 & -0.589672 & -0.750595 \\ \mathrm{~N} & -1.651641 & -0.239434 & 0.562839 \\ \mathrm{C} & -2.523238 & 0.152816 & 1.543316 \\ \mathrm{C} & -2.433745 & -0.373072 & 2.842127 \\ \mathrm{C} & -3.314838 & 0.038791 & 3.828878 \\ \mathrm{C} & -3.525024 & 1.099293 & 1.270185 \\ \mathrm{C} & -4.398892 & 1.504689 & 2.264900 \\ \mathrm{C} & -4.300742 & 0.978842 & 3.549261 \\ \mathrm{H} & -1.661988 & -1.108544 & 3.052269 \\ \mathrm{H} & -3.232002 & -0.379379 & 4.828518 \\ \mathrm{H} & -5.167609 & 2.238044 & 2.036289 \\ \mathrm{H} & -4.988866 & 1.298430 & 4.325946 \\ \mathrm{H} & -3.595696 & 1.501562 & 0.262614 \\ \mathrm{Br} & -1.481706 & 0.589235 & -2.723649 \\ \mathrm{Br} & -0.714488 & -3.001856 & -1.203143 \\ \mathrm{~N} & 1.343052 & -0.464693 & 0.007815 \\ \mathrm{C} & 2.460104 & -0.899943 & 0.728749 \\ \mathrm{C} & 3.148105 & -0.115620 & 1.661516 \\ \mathrm{C} & 4.169522 & -0.692343 & 2.389406 \\ \mathrm{C} & 2.778587 & -2.248749 & 0.549448 \\ \mathrm{C} & 3.830117 & -2.800352 & 1.258170 \\ \mathrm{C} & 4.523269 & -2.023764 & 2.177775 \\ \mathrm{H} & 2.864860 & 0.914725 & 1.841685 \\ \mathrm{H} & 4.696830 & -0.101996 & 3.131268 \\ \mathrm{H} & 4.096498 & -3.841019 & 1.108604 \\ \mathrm{H} & 5.337496 & -2.459781 & 2.747880 \\ \mathrm{H} & 2.193071 & -2.836174 & -0.151537 \\ \mathrm{~N} & 0.954741 & 0.671565 & -0.329881 \\ \mathrm{C} & 1.553282 & 1.937482 & -0.307115 \\ \mathrm{C} & 0.655302 & 3.001494 & -0.201031 \\ \mathrm{C} & 2.919398 & 2.156923 & -0.504814 \\ \mathrm{C} & 2.494756 & 4.524942 & -0.408819 \\ \mathrm{C} & 1.136902 & 4.297802 & -0.222760 \\ \mathrm{C} & 3.377537 & 3.458285 & -0.566689 \\ \mathrm{H} & -0.403327 & 2.785329 & -0.085803 \\ \mathrm{H} & 2.870985 & 5.542308 & -0.447080 \\ \mathrm{H} & 0.451306 & 5.131284 & -0.115436 \\ \mathrm{H} & 4.431523 & 3.647123 & -0.741017 \\ \mathrm{H} & 3.601529 & 1.325457 & -0.643820 \\ & & & \\ & & & \end{array}$

IM1 M06/6-311g(d,p)/superfine in PhCF3 Solvent Electronic energy -7106.961943 a.u.

Gibbs free energy $-7106.651792(-7106.645221)$ a.u. 54

$\begin{array}{lrrr}\mathrm{Ti} & 0.579762 & -0.324960 & 0.125441 \\ \mathrm{~N} & 0.934795 & 1.306815 & -0.060074 \\ \mathrm{C} & 1.308913 & 2.592138 & -0.339849 \\ \mathrm{C} & 2.345597 & 2.846773 & -1.252616 \\ \mathrm{C} & 2.728465 & 4.147863 & -1.532557 \\ \mathrm{C} & 0.666284 & 3.678990 & 0.273461 \\ \mathrm{C} & 1.052646 & 4.976436 & -0.022368 \\ \mathrm{C} & 2.085012 & 5.219766 & -0.921896 \\ \mathrm{H} & 2.833029 & 1.999961 & -1.730921 \\ \mathrm{H} & 3.534582 & 4.329392 & -2.238296 \\ \mathrm{H} & 0.545266 & 5.808459 & 0.458422 \\ \mathrm{H} & 2.386224 & 6.238496 & -1.146371 \\ \mathrm{H} & -0.135333 & 3.477381 & 0.979051 \\ \mathrm{C} & 2.755141 & -0.810277 & 0.279540 \\ \mathrm{~N} & 3.904735 & -0.931467 & 0.328066 \\ \mathrm{C} & 5.351153 & -1.053887 & 0.381365\end{array}$

$\begin{array}{lrrr} & & & \\ \mathrm{C} & 5.930881 & 0.133741 & -0.372132 \\ \mathrm{H} & 5.610035 & 0.125030 & -1.418503 \\ \mathrm{H} & 5.617376 & 1.076716 & 0.086514 \\ \mathrm{H} & 7.023373 & 0.075062 & -0.341130 \\ \mathrm{C} & 5.724034 & -2.370458 & -0.282308 \\ \mathrm{H} & 5.273640 & -3.215571 & 0.247193 \\ \mathrm{H} & 5.393430 & -2.388852 & -1.325313 \\ \mathrm{H} & 6.812411 & -2.483633 & -0.258705 \\ \mathrm{C} & 5.755775 & -1.034123 & 1.847250 \\ \mathrm{H} & 5.453073 & -0.096188 & 2.322637 \\ \mathrm{H} & 5.300521 & -1.868931 & 2.388727 \\ \mathrm{H} & 6.844317 & -1.125664 & 1.915308 \\ \mathrm{Br} & 0.350845 & -0.972658 & 2.505875 \\ \mathrm{Br} & 0.608341 & -1.422195 & -2.076130 \\ \mathrm{~N} & -1.666987 & -0.224974 & 0.025382 \\ \mathrm{C} & -2.462134 & -1.354394 & -0.392595 \\ \mathrm{~N} & -2.144876 & 0.888348 & 0.303009 \\ \mathrm{C} & -3.251984 & -1.249072 & -1.531227 \\ \mathrm{C} & -2.315371 & -2.562482 & 0.274477 \\ \mathrm{C} & -3.527801 & 1.150131 & 0.433632 \\ \mathrm{C} & -3.929097 & -2.368635 & -1.985253 \\ \mathrm{H} & -3.314383 & -0.303982 & -2.062714 \\ \mathrm{C} & -3.016366 & -3.670997 & -0.177667 \\ \mathrm{H} & -1.676388 & -2.62226 & 1.151374 \\ \mathrm{C} & -3.922058 & 2.420202 & 0.011384 \\ \mathrm{C} & -4.436741 & 0.300994 & 1.071011 \\ \mathrm{C} & -3.821565 & -3.576319 & -1.304961 \\ \mathrm{H} & -4.540893 & -2.299024 & -2.879124 \\ \mathrm{H} & -2.924142 & -4.615158 & 0.349756 \\ \mathrm{C} & -5.243451 & 2.809961 & 0.147044 \\ \mathrm{H} & -3.178348 & 3.076507 & -0.431190 \\ \mathrm{C} & -5.742391 & 0.723486 & 1.247289 \\ \mathrm{H} & -4.116765 & -0.660929 & 1.456234 \\ \mathrm{H} & -4.358460 & -4.449264 & -1.662873 \\ \mathrm{C} & -6.153496 & 1.963292 & 0.767880 \\ \mathrm{H} & -5.558747 & 3.785700 & -0.208140 \\ \mathrm{H} & -6.447977 & 0.078354 & 1.761059 \\ \mathrm{H} & -7.184440 & 2.277519 & 0.898142 \\ & & & \\ & & & \\ \mathrm{H} & & & \\ \mathrm{H} & & & \\ \mathrm{H} & & & \\ \mathrm{H} & & & \end{array}$

TS1 M06/6-311g(d,p)/superfine in PhCF3 Solvent Electronic energy -7106.931239 a.u. Gibbs free energy -7106.615869 (-7106.610928) a.u. 54

$\begin{array}{lrrr}\mathrm{Ti} & -0.178475 & -0.641076 & -0.091982 \\ \mathrm{~N} & -1.129505 & 0.548646 & 0.800490 \\ \mathrm{C} & -1.792062 & 1.495522 & 1.543234 \\ \mathrm{C} & -1.835190 & 1.379039 & 2.939148 \\ \mathrm{C} & -2.493653 & 2.331389 & 3.699373 \\ \mathrm{C} & -2.447872 & 2.572140 & 0.929681 \\ \mathrm{C} & -3.101571 & 3.520436 & 1.700618 \\ \mathrm{C} & -3.126536 & 3.407391 & 3.085898 \\ \mathrm{H} & -1.339066 & 0.531667 & 3.404769 \\ \mathrm{H} & -2.514686 & 2.233142 & 4.781106 \\ \mathrm{H} & -3.599309 & 4.355062 & 1.214798 \\ \mathrm{H} & -3.639834 & 4.153236 & 3.685249 \\ \mathrm{H} & -2.430035 & 2.651610 & -0.154017 \\ \mathrm{C} & -2.190809 & -0.494536 & -0.191836 \\ \mathrm{~N} & -3.378395 & -0.244468 & -0.159069 \\ \mathrm{C} & -4.433553 & -0.933138 & -0.927993 \\ \mathrm{C} & -5.638807 & -1.060336 & -0.010153 \\ \mathrm{H} & -5.395079 & -1.674209 & 0.864060 \\ \mathrm{H} & -5.961170 & -0.074529 & 0.341747 \\ \mathrm{H} & -6.472602 & -1.532759 & -0.541692 \\ \mathrm{C} & -3.979913 & -2.304193 & -1.405729 \\ \mathrm{H} & -3.110916 & -2.223635 & -2.068502 \\ \mathrm{H} & -3.704184 & -2.940103 & -0.556500\end{array}$




$\begin{array}{lrrr}\mathrm{H} & -4.790531 & -2.796718 & -1.954934 \\ \mathrm{C} & -4.759010 & -0.032743 & -2.111292 \\ \mathrm{H} & -5.047623 & 0.967327 & -1.768933 \\ \mathrm{H} & -3.889835 & 0.064080 & -2.772203 \\ \mathrm{H} & -5.589034 & -0.455335 & -2.688963 \\ \mathrm{Br} & -0.009587 & -0.881432 & -2.582593 \\ \mathrm{Br} & -0.198745 & -2.734368 & 1.192493 \\ \mathrm{~N} & 2.002712 & -0.431590 & 0.201427 \\ \mathrm{C} & 3.293465 & -0.733213 & 0.662157 \\ \mathrm{~N} & 1.530970 & 0.592969 & -0.318716 \\ \mathrm{C} & 4.114216 & 0.193777 & 1.309695 \\ \mathrm{C} & 3.660996 & -2.075453 & 0.561723 \\ \mathrm{C} & 2.098293 & 1.764319 & -0.832614 \\ \mathrm{C} & 5.324055 & -0.233232 & 1.822706 \\ \mathrm{H} & 3.792950 & 1.221715 & 1.438476 \\ \mathrm{C} & 4.894292 & -2.478136 & 1.044136 \\ \mathrm{H} & 2.976204 & -2.773862 & 0.090764 \\ \mathrm{C} & 1.176746 & 2.793356 & -1.043900 \\ \mathrm{C} & 3.429293 & 1.892664 & -1.244329 \\ \mathrm{C} & 5.723123 & -1.559663 & 1.675411 \\ \mathrm{H} & 5.962996 & 0.471904 & 2.344121 \\ \mathrm{H} & 5.200125 & -3.514286 & 0.946115 \\ \mathrm{C} & 1.599552 & 3.982505 & -1.607594 \\ \mathrm{H} & 0.141239 & 2.630801 & -0.758338 \\ \mathrm{C} & 3.827645 & 3.073524 & -1.838759 \\ \mathrm{H} & 4.130991 & 1.075114 & -1.130278 \\ \mathrm{H} & 6.681395 & -1.879897 & 2.072027 \\ \mathrm{C} & 2.923746 & 4.121271 & -2.004121 \\ \mathrm{H} & 0.894518 & 4.792937 & -1.756852 \\ \mathrm{H} & 4.852069 & 3.182309 & -2.178716 \\ \mathrm{H} & 3.255762 & 5.047979 & -2.461515\end{array}$

IM2 M06/6-311g(d,p)/superfine in PhCF3 Solvent Electronic energy -7106.964384 a.u.

Gibbs free energy -7106.642059 (-7106.638962) a.u.

$\begin{array}{lrrr}54 & & & \\ \mathrm{Ti} & 0.525910 & -0.105344 & -0.731603 \\ \mathrm{~N} & 2.060168 & 0.121602 & 0.380910 \\ \mathrm{C} & 3.441456 & 0.087630 & 0.550960 \\ \mathrm{C} & 4.245687 & -0.402530 & -0.482323 \\ \mathrm{C} & 5.620939 & -0.445582 & -0.330475 \\ \mathrm{C} & 4.034147 & 0.537714 & 1.735653 \\ \mathrm{C} & 5.413053 & 0.487845 & 1.874530 \\ \mathrm{C} & 6.211540 & -0.002032 & 0.848476 \\ \mathrm{H} & 3.774844 & -0.746895 & -1.399104 \\ \mathrm{H} & 6.238486 & -0.827039 & -1.138502 \\ \mathrm{H} & 5.869066 & 0.838217 & 2.796367 \\ \mathrm{H} & 7.290629 & -0.036372 & 0.964558 \\ \mathrm{H} & 3.394655 & 0.924612 & 2.521478 \\ \mathrm{C} & 1.074380 & 0.691274 & 1.089133 \\ \mathrm{~N} & 1.073488 & 1.325658 & 2.193704 \\ \mathrm{C} & -0.163383 & 1.944160 & 2.703067 \\ \mathrm{C} & 0.232412 & 2.719168 & 3.953861 \\ \mathrm{H} & 0.659778 & 2.043431 & 4.703930 \\ \mathrm{H} & 0.988359 & 3.475099 & 3.711472 \\ \mathrm{H} & -0.633988 & 3.225071 & 4.396758 \\ \mathrm{C} & -1.185621 & 0.880365 & 3.084344 \\ \mathrm{H} & -1.523112 & 0.322880 & 2.205439 \\ \mathrm{H} & -0.747475 & 0.164334 & 3.790576 \\ \mathrm{H} & -2.067678 & 1.332884 & 3.555277 \\ \mathrm{C} & -0.752342 & 2.914851 & 1.684575 \\ \mathrm{H} & -0.020141 & 3.691019 & 1.431147 \\ \mathrm{H} & -1.027993 & 2.402923 & 0.755946 \\ \mathrm{H} & -1.650686 & 3.405548 & 2.080815 \\ \mathrm{Br} & 0.902079 & 1.543816 & -2.465168 \\ \mathrm{Br} & 1.100766 & -2.322700 & -1.581161 \\ & & & \end{array}$

$\begin{array}{lrrr}\mathrm{N} & -1.297027 & -0.854225 & -0.033689 \\ \mathrm{C} & -2.038500 & -1.886564 & 0.555451 \\ \mathrm{~N} & -1.628866 & 0.185522 & -0.640880 \\ \mathrm{C} & -3.318767 & -2.255169 & 0.131714 \\ \mathrm{C} & -1.352508 & -2.632083 & 1.516892 \\ \mathrm{C} & -2.842222 & 0.875389 & -0.715187 \\ \mathrm{C} & -3.915688 & -3.358815 & 0.708420 \\ \mathrm{H} & -3.822303 & -1.709228 & -0.658300 \\ \mathrm{C} & -1.980242 & -3.710322 & 2.113208 \\ \mathrm{H} & -0.341285 & -2.343541 & 1.788416 \\ \mathrm{C} & -2.932914 & 1.782902 & -1.775047 \\ \mathrm{C} & -3.834666 & 0.822150 & 0.271581 \\ \mathrm{C} & -3.258859 & -4.072793 & 1.708771 \\ \mathrm{H} & -4.900753 & -3.669243 & 0.377142 \\ \mathrm{H} & -1.465064 & -4.280190 & 2.878818 \\ \mathrm{C} & -4.045507 & 2.596930 & -1.883186 \\ \mathrm{H} & -2.123268 & 1.828104 & -2.497054 \\ \mathrm{C} & -4.919735 & 1.669295 & 0.169748 \\ \mathrm{H} & -3.740896 & 0.156877 & 1.122443 \\ \mathrm{H} & -3.745691 & -4.929684 & 2.163773 \\ \mathrm{C} & -5.035150 & 2.543130 & -0.910468 \\ \mathrm{H} & -4.130384 & 3.289116 & -2.713858 \\ \mathrm{H} & -5.684500 & 1.653461 & 0.938857 \\ \mathrm{H} & -5.899585 & 3.195755 & -0.982096\end{array}$

TS2 M06/6-311g(d,p)/superfine in PhCF3 Solvent Geometry found from NEB scan

Electronic energy -7106.960985 a.u.

Gibbs free energy $-7106.637962(-7106.634819)$ a.u

$\begin{array}{lrrr}54 & & & \\ \mathrm{Ti} & 0.000000 & 0.000000 & 0.000000 \\ \mathrm{~N} & 2.213250 & 0.252322 & 0.513241 \\ \mathrm{C} & 3.607841 & 0.265790 & 0.695364 \\ \mathrm{C} & 4.429243 & -0.216077 & -0.328099 \\ \mathrm{C} & 5.804487 & -0.251882 & -0.167448 \\ \mathrm{C} & 4.197008 & 0.725532 & 1.881402 \\ \mathrm{C} & 5.576985 & 0.678959 & 2.028658 \\ \mathrm{C} & 6.387365 & 0.191414 & 1.012939 \\ \mathrm{H} & 3.970017 & -0.565698 & -1.247731 \\ \mathrm{H} & 6.430407 & -0.633140 & -0.968776 \\ \mathrm{H} & 6.030994 & 1.028681 & 2.952581 \\ \mathrm{H} & 7.466875 & 0.158779 & 1.137786 \\ \mathrm{H} & 3.566833 & 1.117144 & 2.671827 \\ \mathrm{C} & 1.230232 & 0.813766 & 1.237258 \\ \mathrm{~N} & 1.249236 & 1.485720 & 2.314689 \\ \mathrm{C} & 0.042327 & 2.121226 & 2.856938 \\ \mathrm{C} & 0.453978 & 2.894557 & 4.107898 \\ \mathrm{H} & 0.880383 & 2.222641 & 4.860394 \\ \mathrm{H} & 1.207679 & 3.651521 & 3.866936 \\ \mathrm{H} & -0.412011 & 3.402247 & 4.551603 \\ \mathrm{C} & -0.983272 & 1.064682 & 3.249215 \\ \mathrm{H} & -1.316033 & 0.501834 & 2.369634 \\ \mathrm{H} & -0.537822 & 0.356084 & 3.956804 \\ \mathrm{H} & -1.861250 & 1.522308 & 3.722007 \\ \mathrm{C} & -0.548792 & 3.101315 & 1.848012 \\ \mathrm{H} & 0.188180 & 3.871721 & 1.595801 \\ \mathrm{H} & -0.827802 & 2.592135 & 0.917751 \\ \mathrm{H} & -1.439837 & 3.597077 & 2.254010 \\ \mathrm{Br} & 0.923260 & 1.537385 & -2.389335 \\ \mathrm{Br} & 1.134529 & -2.234707 & -1.488973 \\ \mathrm{~N} & -1.245493 & -0.802902 & 0.035477 \\ \mathrm{C} & -2.013697 & -1.859601 & 0.571920 \\ \mathrm{~N} & -1.582584 & 0.221793 & -0.600152 \\ \mathrm{C} & -3.288914 & -2.238265 & 0.132320 \\ \mathrm{C} & -1.344797 & -2.619605 & 1.530903 \\ \mathrm{C} & -2.819389 & 0.875125 & -0.710540 \\ & & & \\ & & & \end{array}$




$\begin{array}{lrrr}\mathrm{C} & -3.894465 & -3.343259 & 0.702422 \\ \mathrm{H} & -3.795629 & -1.689514 & -0.653925 \\ \mathrm{C} & -1.974191 & -3.705627 & 2.112818 \\ \mathrm{H} & -0.332869 & -2.333577 & 1.802396 \\ \mathrm{C} & -2.922962 & 1.776108 & -1.775382 \\ \mathrm{C} & -3.820082 & 0.821983 & 0.268187 \\ \mathrm{C} & -3.250223 & -4.064814 & 1.704148 \\ \mathrm{H} & -4.880837 & -3.650993 & 0.368837 \\ \mathrm{H} & -1.461765 & -4.281798 & 2.874899 \\ \mathrm{C} & -4.040141 & 2.586431 & -1.882404 \\ \mathrm{H} & -2.110024 & 1.828157 & -2.493669 \\ \mathrm{C} & -4.911797 & 1.661483 & 0.164480 \\ \mathrm{H} & -3.725193 & 0.160157 & 1.121320 \\ \mathrm{H} & -3.743231 & -4.920913 & 2.155295 \\ \mathrm{C} & -5.031161 & 2.535930 & -0.912021 \\ \mathrm{H} & -4.125093 & 3.282947 & -2.709761 \\ \mathrm{H} & -5.674465 & 1.645610 & 0.936135 \\ \mathrm{H} & -5.894422 & 3.190766 & -0.981003\end{array}$

IM3 M06/6-311g(d,p)/superfine in PhCF3 Solvent Electronic energy -6570.115848 a.u.

Gibbs free energy -6569.991377 (-6569.991042) a.u.

$\begin{array}{lrrr}27 & & & \\ \mathrm{Br} & 1.416906 & -2.353447 & 0.483714 \\ \mathrm{Br} & -2.346746 & -2.045862 & -0.065193 \\ \mathrm{Ti} & -0.191573 & -1.091749 & -0.766839 \\ \mathrm{~N} & 0.667368 & 0.580548 & -0.801297 \\ \mathrm{C} & 1.905818 & 1.055386 & -0.351769 \\ \mathrm{~N} & -0.415637 & 0.537540 & 0.083449 \\ \mathrm{C} & 2.049433 & 1.749431 & 0.849401 \\ \mathrm{C} & 3.020270 & 0.823784 & -1.160898 \\ \mathrm{C} & -1.367365 & 1.570718 & 0.077099 \\ \mathrm{C} & 3.306756 & 2.187368 & 1.239175 \\ \mathrm{H} & 1.181093 & 1.928072 & 1.475972 \\ \mathrm{C} & 4.268780 & 1.265312 & -0.760093 \\ \mathrm{H} & 2.888646 & 0.289905 & -2.098666 \\ \mathrm{C} & -2.474964 & 1.457708 & 0.920153 \\ \mathrm{C} & -1.208971 & 2.706792 & -0.717708 \\ \mathrm{C} & 4.419020 & 1.948824 & 0.442113 \\ \mathrm{H} & 3.416500 & 2.720190 & 2.179371 \\ \mathrm{H} & 5.132628 & 1.072219 & -1.389421 \\ \mathrm{C} & -3.425566 & 2.463263 & 0.945930 \\ \mathrm{H} & -2.575207 & 0.576624 & 1.546133 \\ \mathrm{C} & -2.170473 & 3.706655 & -0.681773 \\ \mathrm{H} & -0.339323 & 2.792723 & -1.361760 \\ \mathrm{H} & 5.399063 & 2.294110 & 0.755377 \\ \mathrm{C} & -3.280346 & 3.591509 & 0.144364 \\ \mathrm{H} & -4.286775 & 2.368287 & 1.600668 \\ \mathrm{H} & -2.045965 & 4.586760 & -1.306107 \\ \mathrm{H} & -4.028120 & 4.378281 & 0.169620 \\ & & & \\ & & & \end{array}$


II. Competing Pathways for catalytic production of tBuNCNtBu (Fig. 7).

Isocyanide Metathesis (Blue)

Same starting pathway in SI Part I where $\mathrm{L}=$ pyridine/pyridine for geometries IM0-IM2

IM3-ICM M06/6-311g(d,p)/superfine in PhCF3 Solvent Electronic energy -7030.847080 a.u.

Gibbs free energy -7030.533193 (-7030.530566) a.u. 52

\begin{tabular}{|c|c|c|c|}
\hline $\mathrm{Ti}$ & -0.603501 & -0.391615 & 0.007038 \\
\hline $\mathrm{N}$ & -2.766837 & 0.054664 & -0.647110 \\
\hline $\mathrm{N}$ & -0.935315 & 1.718446 & 0.693292 \\
\hline $\mathrm{N}$ & 2.047057 & 1.057579 & -0.907253 \\
\hline $\mathrm{C}$ & 3.433232 & 1.158227 & -0.765533 \\
\hline $\mathrm{C}$ & 4.254771 & 1.027171 & -1.890514 \\
\hline $\mathrm{C}$ & 5.630490 & 1.157661 & -1.780436 \\
\hline $\mathrm{C}$ & 4.028429 & 1.476767 & 0.460428 \\
\hline $\mathrm{C}$ & 5.405850 & 1.610459 & 0.563641 \\
\hline $\mathrm{C}$ & 6.217687 & 1.443533 & -0.552214 \\
\hline $\mathrm{H}$ & 3.790682 & 0.798548 & -2.846932 \\
\hline $\mathrm{H}$ & 6.252301 & 1.033387 & -2.663306 \\
\hline $\mathrm{H}$ & 5.849622 & 1.849629 & 1.526795 \\
\hline $\mathrm{H}$ & 7.295436 & 1.546288 & -0.468563 \\
\hline $\mathrm{H}$ & 3.393494 & 1.614601 & 1.332722 \\
\hline $\mathrm{C}$ & -0.399771 & 2.716779 & -0.029943 \\
\hline $\mathrm{C}$ & -1.833697 & 2.038703 & 1.641138 \\
\hline $\mathrm{C}$ & -0.755390 & 4.041906 & 0.151508 \\
\hline $\mathrm{C}$ & -2.227071 & 3.337883 & 1.889236 \\
\hline $\mathrm{C}$ & -1.686584 & 4.361568 & 1.124539 \\
\hline $\mathrm{H}$ & 0.355063 & 2.436445 & -0.762333 \\
\hline $\mathrm{H}$ & -0.295797 & 4.804995 & -0.466229 \\
\hline $\mathrm{H}$ & -1.985006 & 5.391948 & 1.289444 \\
\hline $\mathrm{H}$ & -2.953022 & 3.535764 & 2.669540 \\
\hline $\mathrm{H}$ & -2.249234 & 1.213685 & 2.210385 \\
\hline $\mathrm{C}$ & -3.868947 & -0.533540 & -0.172812 \\
\hline $\mathrm{C}$ & -5.133557 & -0.240416 & -0.653359 \\
\hline $\mathrm{C}$ & -5.264072 & 0.695630 & -1.666405 \\
\hline $\mathrm{C}$ & -4.121815 & 1.300998 & -2.170607 \\
\hline $\mathrm{C}$ & -2.898286 & 0.949754 & -1.634684 \\
\hline $\mathrm{H}$ & -3.722674 & -1.259079 & 0.623166 \\
\hline $\mathrm{H}$ & -5.997400 & -0.742575 & -0.232870 \\
\hline $\mathrm{H}$ & -6.242457 & 0.948934 & -2.062108 \\
\hline $\mathrm{H}$ & -1.981103 & 1.400864 & -2.011602 \\
\hline $\mathrm{H}$ & -4.172141 & 2.033450 & -2.968160 \\
\hline $\mathrm{C}$ & 1.302895 & 0.199707 & -0.316407 \\
\hline $\mathrm{N}$ & 1.234765 & -0.896261 & 0.392370 \\
\hline $\mathrm{C}$ & 2.197706 & -1.930440 & 0.842562 \\
\hline $\mathrm{C}$ & 3.330942 & -2.068361 & -0.166947 \\
\hline $\mathrm{H}$ & 2.936669 & -2.211214 & -1.180486 \\
\hline $\mathrm{H}$ & 3.989712 & -1.196174 & -0.168175 \\
\hline $\mathrm{H}$ & 3.935768 & -2.946323 & 0.087979 \\
\hline $\mathrm{C}$ & 1.469415 & -3.262346 & 0.951467 \\
\hline $\mathrm{H}$ & 0.638368 & -3.207000 & 1.659508 \\
\hline $\mathrm{H}$ & 1.072198 & -3.569976 & -0.021637 \\
\hline $\mathrm{H}$ & 2.168688 & -4.031346 & 1.298807 \\
\hline $\mathrm{C}$ & 2.736801 & -1.521466 & 2.206828 \\
\hline $\mathrm{H}$ & 3.263923 & -0.563140 & 2.152373 \\
\hline $\mathrm{H}$ & 1.922124 & -1.433221 & 2.933647 \\
\hline $\mathrm{H}$ & 3.443123 & -2.277978 & 2.569599 \\
\hline $\mathrm{Br}$ & -0.779159 & -2.021579 & -1.870037 \\
\hline $\mathrm{Br}$ & -1.375218 & -1.345766 & 2.168196 \\
\hline
\end{tabular}

TS3-ICM M06/6-311g(d,p)/superfine in PhCF3 Solvent Electronic energy -7030.818837 a.u.
Gibbs free energy -7030.511023 (-7030.508010) a.u. 52

$-0.830692$

$\mathrm{N} \quad-2.286162 \quad 0.728332 \quad-1.146391$

$\begin{array}{lllr}\mathrm{N} & 1.931486 & 0.386582 & -1.267140\end{array}$

$\begin{array}{llll}\mathrm{C} & 3.295881 & 0.562473 & -1.158441\end{array}$

C $\quad 4.175374 \quad-0.140720 \quad-1.982147$

$\begin{array}{llll}\mathrm{C} & 5.540741 & 0.073010 & -1.866807\end{array}$

$\begin{array}{llll}\mathrm{C} & 3.790547 & 1.506978 & -0.254556\end{array}$

C $\quad 5.156461 \quad 1.716361 \quad-0.158553$

$\begin{array}{llll}\mathrm{C} & 6.039005 & 0.997332 & -0.956886\end{array}$

$\mathrm{H} \quad 3.777503 \quad-0.853954 \quad-2.698041$

$\mathrm{H} \quad \begin{array}{llll}3.221821 & -0.488108 & -2.500002\end{array}$

$\begin{array}{llll}\mathrm{H} & 5.535440 & 2.445495 & 0.551759\end{array}$

$\mathrm{H} \quad 7.108745 \quad 1.162213 \quad-0.875004$

$\begin{array}{llll}\mathrm{H} & 3.090995 & 2.053710 & 0.373185\end{array}$

$\begin{array}{llll}\mathrm{C} & -0.410700 & 2.662694 & 0.368240\end{array}$

$\begin{array}{llll}\mathrm{C} & -0.001751 & 1.538926 & 2.326863\end{array}$

$\begin{array}{llll}\mathrm{C} & -0.018382 & 3.866844 & 0.925656\end{array}$

$\begin{array}{llll}\mathrm{C} & 0.409994 & 2.697845 & 2.958365\end{array}$

$\begin{array}{llll}\mathrm{C} & 0.399102 & 3.887557 & 2.246662\end{array}$

H $\quad-0.724394 \quad 2.616012 \quad-0.670278$

$\begin{array}{llll}\mathrm{H} & -0.037769 & 4.767528 & 0.322804\end{array}$

$\begin{array}{llll}\mathrm{H} & 0.715361 & 4.814915 & 2.713477\end{array}$

$\begin{array}{llll}\mathrm{H} & 0.733581 & 2.658447 & 3.992189\end{array}$

H $\quad-0.005564 \quad 0.590602 \quad 2.855865$

C $\quad-3.374204 \quad 1.313976 \quad-0.631791$

$\begin{array}{llll}\mathrm{C} & -4.204982 & 2.136858 & -1.372297\end{array}$

$\begin{array}{llll}\mathrm{C} & -3.900676 & 2.367695 & -2.704183\end{array}$

$\begin{array}{llll}\mathrm{C} & -2.779055 & 1.758905 & -3.247369\end{array}$

$\begin{array}{llll}\mathrm{C} & -2.005246 & 0.947946 & -2.437889\end{array}$

$\begin{array}{llll}\mathrm{H} & -3.576401 & 1.113304 & 0.417360\end{array}$

H $\quad-5.073085 \quad 2.586617 \quad-0.903764$

$\mathrm{H} \quad-4.529150 \quad 3.010968 \quad-3.311987$

H $\quad-1.118732 \quad 0.456674 \quad-2.828999$

$\mathrm{H} \quad-2.501352 \quad 1.906333 \quad-4.284908$

C $\quad 0.903785 \quad-0.044320 \quad-0.787670$

$\mathrm{N} \quad 0.756512 \quad-1.158521 \quad 0.589347$

$\begin{array}{llll}\mathrm{C} & 1.812979 & -2.071718 & 1.002733\end{array}$

C $\quad 2.323900 \quad-2.871930 \quad-0.190000$

$\mathrm{H} \quad \begin{array}{llll}\mathrm{H} & 1.494455 & -3.384759 & -0.688983\end{array}$

H $\quad 2.826986 \quad-2.231804 \quad-0.921186$

$\mathrm{H} \quad 3.045515 \quad-3.624014 \quad 0.150618$

C $\quad 1.153700 \quad-3.019013 \quad 2.005773$

$\mathrm{H} \quad 0.777316 \quad-2.460902 \quad 2.870977$

H $\quad 0.308796 \quad-3.541440 \quad 1.544334$

$\begin{array}{llll}\mathrm{H} & 1.878383 & -3.762456 & 2.359563\end{array}$

C $\quad 2.955026 \quad-1.335794 \quad 1.696702$

$\mathrm{H} \quad 3.543374 \quad-0.735759 \quad 0.997855$

$\begin{array}{llll}\mathrm{H} & 2.568653 & -0.676842 & 2.483470\end{array}$

$\mathrm{H} \quad 3.630715 \quad-2.062177 \quad 2.164097$

$\mathrm{Br} \quad-2.466734 \quad-0.884151 \quad 2.027625$

$\mathrm{Br} \quad-1.501242 \quad-2.419189 \quad-1.358544$

IM4-ICM M06/6-311g(d,p)/superfine in PhCF3 Solvent Electronic energy -7030.848755 a.u.

Gibbs free energy -7030.546657 (-7030.540683) a.u. 52

$\begin{array}{lrrr}\mathrm{Ti} & 0.572366 & -0.304168 & -0.027437 \\ \mathrm{~N} & 0.854045 & 2.130505 & 0.085211 \\ \mathrm{~N} & 2.808304 & -0.351428 & 0.063385 \\ \mathrm{~N} & 0.300057 & -1.953344 & -0.102510 \\ \mathrm{C} & -0.039113 & -3.347061 & -0.081035 \\ \mathrm{C} & 3.457308 & -1.160894 & -0.786021 \\ \mathrm{C} & 3.530408 & 0.354707 & 0.943175\end{array}$




$\begin{array}{lrrr}\mathrm{C} & 4.833545 & -1.287659 & -0.791378 \\ \mathrm{C} & 4.910438 & 0.284353 & 1.002996 \\ \mathrm{C} & 5.575435 & -0.551545 & 0.120011 \\ \mathrm{H} & 2.838031 & -1.718447 & -1.482467 \\ \mathrm{H} & 5.308647 & -1.957055 & -1.499338 \\ \mathrm{H} & 6.657683 & -0.631077 & 0.143329 \\ \mathrm{H} & 5.446946 & 0.876764 & 1.735335 \\ \mathrm{H} & 2.971318 & 0.987758 & 1.626329 \\ \mathrm{C} & 0.093276 & 2.890412 & 0.880487 \\ \mathrm{C} & 0.175557 & 4.272547 & 0.915203 \\ \mathrm{C} & 1.103062 & 4.905196 & 0.103309 \\ \mathrm{C} & 1.904328 & 4.127722 & -0.718573 \\ \mathrm{C} & 1.738478 & 2.753692 & -0.702317 \\ \mathrm{H} & -0.601270 & 2.361499 & 1.527642 \\ \mathrm{H} & -0.476089 & 4.834635 & 1.575120 \\ \mathrm{H} & 1.200364 & 5.986456 & 0.110222 \\ \mathrm{H} & 2.331519 & 2.120373 & -1.356564 \\ \mathrm{H} & 2.646188 & 4.573512 & -1.371980 \\ \mathrm{C} & -1.632744 & 0.103115 & -0.062173 \\ \mathrm{~N} & -2.792959 & 0.176870 & -0.073125 \\ \mathrm{C} & -4.175823 & 0.229504 & -0.070609 \\ \mathrm{C} & -4.827249 & 1.081468 & -0.957118 \\ \mathrm{C} & -4.879504 & -0.574751 & 0.821189 \\ \mathrm{C} & -6.211566 & 1.124137 & -0.944461 \\ \mathrm{H} & -4.245280 & 1.692271 & -1.639071 \\ \mathrm{C} & -6.263435 & -0.518430 & 0.819585 \\ \mathrm{H} & -4.336184 & -1.225662 & 1.498573 \\ \mathrm{C} & -6.928495 & 0.327849 & -0.059500 \\ \mathrm{H} & -6.732947 & 1.783479 & -1.630715 \\ \mathrm{H} & -6.825209 & -1.139510 & 1.509630 \\ \mathrm{H} & -8.013243 & 0.366766 & -0.055077 \\ \mathrm{C} & -1.467368 & -3.497087 & 0.441612 \\ \mathrm{H} & -1.751391 & -4.555076 & 0.509312 \\ \mathrm{H} & -1.556350 & -3.045600 & 1.436868 \\ \mathrm{H} & -2.174493 & -2.993286 & -0.228935 \\ \mathrm{C} & 0.058280 & -3.912518 & -1.495934 \\ \mathrm{H} & -0.610633 & -3.365484 & -2.169775 \\ \mathrm{H} & 1.079576 & -3.812690 & -1.882387 \\ \mathrm{H} & -0.215812 & -4.975342 & -1.514686 \\ \mathrm{C} & 0.932764 & -4.072473 & 0.848023 \\ \mathrm{H} & 0.876404 & -3.651530 & 1.858116 \\ \mathrm{H} & 0.702099 & -5.144361 & 0.899857 \\ \mathrm{H} & 1.963087 & -3.960011 & 0.489745 \\ \mathrm{Br} & 0.375491 & -0.099984 & 2.532678 \\ \mathrm{Br} & 0.522034 & 0.159167 & -2.551393\end{array}$

$\begin{array}{lrrr}\mathrm{C} & 3.672443 & -2.833606 & 0.456592 \\ \mathrm{C} & 2.728352 & -2.712208 & 1.463838 \\ \mathrm{C} & 1.612841 & -1.924442 & 1.241389 \\ \mathrm{H} & 2.123189 & -0.864664 & -1.809681 \\ \mathrm{H} & 4.177092 & -2.234027 & -1.558138 \\ \mathrm{H} & 4.557587 & -3.444668 & 0.601437 \\ \mathrm{H} & 0.841797 & -1.800256 & 1.995430 \\ \mathrm{H} & 2.847521 & -3.219713 & 2.414212 \\ \mathrm{C} & -1.997974 & 0.145780 & 2.332914 \\ \mathrm{C} & -2.265082 & 1.637049 & 2.521696 \\ \mathrm{H} & -2.980512 & 1.806064 & 3.336610 \\ \mathrm{H} & -1.337873 & 2.170224 & 2.763751 \\ \mathrm{H} & -2.674208 & 2.067840 & 1.601129 \\ \mathrm{C} & -3.298956 & -0.580695 & 2.003785 \\ \mathrm{H} & -3.111811 & -1.649777 & 1.853759 \\ \mathrm{H} & -4.029002 & -0.462688 & 2.814735 \\ \mathrm{H} & -3.731598 & -0.182048 & 1.078947 \\ \mathrm{C} & -1.380565 & -0.440185 & 3.600185 \\ \mathrm{H} & -0.426278 & 0.049463 & 3.830601 \\ \mathrm{H} & -2.050805 & -0.302435 & 4.457930 \\ \mathrm{H} & -1.197573 & -1.514349 & 3.479471 \\ \mathrm{Br} & -1.318838 & -2.161392 & -1.386153 \\ \mathrm{Br} & -1.726040 & 1.576364 & -1.631496\end{array}$

IM5-ICM M06/6-311 g(d,p)/superfine in PhCF3 Solvent Electronic energy -6706.532973 a.u.

Gibbs free energy -6706.307015 (-6706.305404) a.u.

$\begin{array}{lrrr}39 & & & \\ \mathrm{Ti} & -0.418332 & -0.084991 & -0.292310 \\ \mathrm{~N} & 1.414645 & -1.276370 & 0.087947 \\ \mathrm{~N} & 1.145326 & 1.504371 & -0.072034 \\ \mathrm{~N} & -1.080730 & -0.024830 & 1.230678 \\ \mathrm{C} & 1.575704 & 1.839624 & 1.151187 \\ \mathrm{C} & 1.719253 & 2.089555 & -1.130973 \\ \mathrm{C} & 2.582920 & 2.764589 & 1.358426 \\ \mathrm{C} & 2.738892 & 3.015923 & -1.010748 \\ \mathrm{C} & 3.177409 & 3.362068 & 0.258462 \\ \mathrm{H} & 1.085064 & 1.339324 & 1.980781 \\ \mathrm{H} & 2.890180 & 3.006393 & 2.369556 \\ \mathrm{H} & 3.971620 & 4.090743 & 0.387637 \\ \mathrm{H} & 3.171915 & 3.458488 & -1.900144 \\ \mathrm{H} & 1.335406 & 1.808126 & -2.108142 \\ \mathrm{C} & 2.326740 & -1.398682 & -0.882984 \\ \mathrm{C} & 3.467627 & -2.164511 & -0.741682\end{array}$


Carbodiimide Metathesis (Red)

Same start in SI Part I where L=pyridine/pyridine for IM0 geometry

TS1-CM M06/6-311g(d,p)/superfine in PhCF3 Solvent Electronic energy -7317.123806 a.u.

Gibbs free energy $-7316.727105(-7316.724240)$ a.u. 64

\begin{tabular}{|c|c|c|c|}
\hline $\mathrm{Ti}$ & 0.803635 & -0.499894 & -0.131973 \\
\hline $\mathrm{N}$ & 3.159720 & 0.071506 & -0.129408 \\
\hline $\mathrm{N}$ & 0.598054 & 1.556834 & -1.098861 \\
\hline $\mathrm{N}$ & -0.909495 & -0.801230 & -0.221813 \\
\hline $\mathrm{C}$ & -2.083462 & -1.484737 & -0.460308 \\
\hline $\mathrm{C}$ & -2.819752 & -1.251851 & -1.628416 \\
\hline $\mathrm{C}$ & -3.981538 & -1.964613 & -1.876176 \\
\hline $\mathrm{C}$ & -2.538463 & -2.446874 & 0.450151 \\
\hline $\mathrm{C}$ & -3.704523 & -3.150410 & 0.196842 \\
\hline $\mathrm{C}$ & -4.432726 & -2.911649 & -0.963504 \\
\hline $\mathrm{H}$ & -2.469551 & -0.501461 & -2.331607 \\
\hline $\mathrm{H}$ & -4.543039 & -1.775867 & -2.786822 \\
\hline $\mathrm{H}$ & -4.047491 & -3.894974 & 0.909844 \\
\hline $\mathrm{H}$ & -5.346607 & -3.464956 & -1.158216 \\
\hline $\mathrm{H}$ & -1.957137 & -2.632551 & 1.348699 \\
\hline $\mathrm{C}$ & -0.174421 & 1.686280 & -2.187621 \\
\hline $\mathrm{C}$ & 1.080888 & 2.673221 & -0.538917 \\
\hline $\mathrm{C}$ & -0.496501 & 2.914359 & -2.735842 \\
\hline $\mathrm{C}$ & 0.806435 & 3.939836 & -1.021663 \\
\hline $\mathrm{C}$ & -0.002489 & 4.064822 & -2.140308 \\
\hline $\mathrm{H}$ & -0.535418 & 0.763863 & -2.630209 \\
\hline $\mathrm{H}$ & -1.127100 & 2.957593 & -3.616624 \\
\hline $\mathrm{H}$ & -0.240384 & 5.043511 & -2.544638 \\
\hline $\mathrm{H}$ & 1.225178 & 4.806668 & -0.522988 \\
\hline $\mathrm{H}$ & 1.716348 & 2.540562 & 0.330630 \\
\hline $\mathrm{C}$ & 3.666781 & 0.824747 & -1.115965 \\
\hline $\mathrm{C}$ & 5.007760 & 1.146514 & -1.215324 \\
\hline $\mathrm{C}$ & 5.883965 & 0.660646 & -0.256974 \\
\hline $\mathrm{C}$ & 5.377567 & -0.135336 & 0.756549 \\
\hline $\mathrm{C}$ & 4.019726 & -0.404665 & 0.779014 \\
\hline $\mathrm{H}$ & 2.967485 & 1.173861 & -1.869017 \\
\hline $\mathrm{H}$ & 5.352541 & 1.761894 & -2.038738 \\
\hline $\mathrm{H}$ & 6.943637 & 0.890968 & -0.306069 \\
\hline $\mathrm{H}$ & 3.597519 & -1.045177 & 1.547023 \\
\hline $\mathrm{H}$ & 6.019810 & -0.554046 & 1.523276 \\
\hline $\mathrm{C}$ & -0.994897 & 0.301854 & 1.414583 \\
\hline $\mathrm{N}$ & -2.165628 & 0.447145 & 1.789236 \\
\hline $\mathrm{C}$ & -3.260016 & 0.930102 & 1.080294 \\
\hline $\mathrm{C}$ & -3.098094 & 1.892279 & 0.077681 \\
\hline $\mathrm{C}$ & -4.543386 & 0.487765 & 1.402591 \\
\hline $\mathrm{C}$ & -4.198990 & 2.371815 & -0.613190 \\
\hline $\mathrm{H}$ & -2.097257 & 2.253571 & -0.152223 \\
\hline $\mathrm{C}$ & -5.639241 & 0.974628 & 0.707356 \\
\hline $\mathrm{H}$ & -4.660365 & -0.252245 & 2.189204 \\
\hline $\mathrm{C}$ & -5.474610 & 1.911093 & -0.307435 \\
\hline $\mathrm{H}$ & -4.058237 & 3.112746 & -1.396067 \\
\hline $\mathrm{H}$ & -6.633217 & 0.614857 & 0.957379 \\
\hline $\mathrm{H}$ & -6.336715 & 2.285343 & -0.850931 \\
\hline $\mathrm{N}$ & 0.244216 & 0.474971 & 1.661693 \\
\hline $\mathrm{C}$ & 0.629331 & 1.218160 & 2.910135 \\
\hline $\mathrm{C}$ & 0.005134 & 2.606985 & 2.920094 \\
\hline $\mathrm{H}$ & -1.088186 & 2.558376 & 2.904366 \\
\hline $\mathrm{H}$ & 0.303510 & 3.132489 & 3.834307 \\
\hline $\mathrm{H}$ & 0.338621 & 3.202700 & 2.063813 \\
\hline $\mathrm{C}$ & 2.141255 & 1.317741 & 2.961279 \\
\hline $\mathrm{H}$ & 2.593530 & 0.321419 & 2.974332 \\
\hline $\mathrm{H}$ & 2.553354 & 1.879259 & 2.115908 \\
\hline $\mathrm{H}$ & & 18247 & \\
\hline
\end{tabular}

$\begin{array}{lrrr}\mathrm{C} & 0.144877 & 0.406038 & 4.104926 \\ \mathrm{H} & 0.466026 & 0.889715 & 5.034232 \\ \mathrm{H} & -0.946386 & 0.327919 & 4.121774 \\ \mathrm{H} & 0.566758 & -0.604606 & 4.076480 \\ \mathrm{Br} & 1.423526 & -2.586345 & 1.137247 \\ \mathrm{Br} & 1.345442 & -1.423529 & -2.420368\end{array}$

IM2-CM M06/6-311g(d,p)/superfine in PhCF3 Solvent Electronic energy -7317.155478 a.u. Gibbs free energy -7316.757034 (-7316.753558) a.u. 64

$\mathrm{N} \quad 3.254182 \quad-0.147922 \quad-0.008692$

$\mathrm{N} \quad 1.068326 \quad 1.265655 \quad-1.448685$

$\begin{array}{llll}\mathrm{N} & -1.038460 & -0.340920 & -0.005611\end{array}$

$\begin{array}{llll}\text { C } & -2.080176 & -1.246739 & -0.283108\end{array}$

$\begin{array}{llll}\text { C } & -2.392645 & -1.611185 & -1.591919\end{array}$

$\begin{array}{llll}\text { C } & -3.431512 & -2.493581 & -1.846254\end{array}$

$\begin{array}{llll}\text { C } & -2.811354 & -1.808714 & 0.765507\end{array}$

$\begin{array}{llll}\text { C } & -3.854827 & -2.683721 & 0.506293\end{array}$

$\begin{array}{llll}\text { C } & -4.174478 & -3.027629 & -0.800856\end{array}$

$\mathrm{H} \quad-1.828977 \quad-1.182329 \quad-2.413853$

$\begin{array}{llll}\mathrm{H} & -3.669279 & -2.758497 & -2.872680\end{array}$

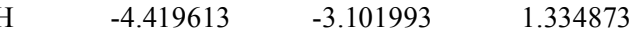

$\mathrm{H} \quad-4.993653 \quad-3.711313 \quad-1.002679$

$\begin{array}{llll}\mathrm{H} & -2.562265 & -1.543379 & 1.789729\end{array}$

$\begin{array}{llll}\mathrm{C} & 0.345566 & 1.187397 & -2.575106\end{array}$

$\begin{array}{llll}\mathrm{C} & 1.766648 & 2.389198 & -1.229214\end{array}$

$\begin{array}{llll}\text { C } & 0.289698 & 2.212825 & -3.502683\end{array}$

$\begin{array}{llll}\mathrm{C} & 1.772421 & 3.455453 & -2.108311\end{array}$

$\begin{array}{llll}\mathrm{C} & 1.016004 & 3.368859 & -3.267242\end{array}$

$\begin{array}{llll}\mathrm{H} & -0.197372 & 0.262364 & -2.736185\end{array}$

$\begin{array}{llll}\mathrm{H} & -0.315202 & 2.094873 & -4.394804\end{array}$

$\begin{array}{llll}\mathrm{H} & 0.994675 & 4.190057 & -3.977365\end{array}$

$\begin{array}{llll}\mathrm{H} & 2.360934 & 4.336153 & -1.877578\end{array}$

$\begin{array}{llll}\mathrm{H} & 2.351269 & 2.428841 & -0.314423\end{array}$

$\begin{array}{llll}\text { C } & 3.841640 & -0.080039 & -1.214413\end{array}$

$\begin{array}{llll}\text { C } & 5.211683 & -0.036345 & -1.384792\end{array}$

$\begin{array}{llll}\text { C } & 6.027744 & -0.062973 & -0.264372\end{array}$

$\begin{array}{llll}\mathrm{C} & 5.434780 & -0.137782 & 0.984903\end{array}$

$\begin{array}{llll}\text { C } & 4.054988 & -0.183989 & 1.066562\end{array}$

$\begin{array}{llll}\mathrm{H} & 3.182792 & -0.073218 & -2.076382\end{array}$

$\begin{array}{llll}\mathrm{H} & 5.623998 & 0.012184 & -2.386106\end{array}$

$\begin{array}{llll}\mathrm{H} & 7.108066 & -0.032845 & -0.364391\end{array}$

$\begin{array}{llll}\mathrm{H} & 3.568293 & -0.268771 & 2.031768\end{array}$

$\begin{array}{llll}\mathrm{H} & 6.025263 & -0.169454 & 1.893459\end{array}$

$\begin{array}{llll}\mathrm{C} & -1.201201 & 0.732319 & 0.876644\end{array}$

$\begin{array}{llll}\mathrm{N} & -2.255292 & 1.375571 & 1.233972\end{array}$

$\begin{array}{llll}\mathrm{C} & -3.494965 & 1.270393 & 0.615568\end{array}$

$\begin{array}{llll}\text { C } & -3.668203 & 1.428105 & -0.765881\end{array}$

$\begin{array}{llll}\mathrm{C} & -4.637870 & 1.110268 & 1.409819\end{array}$

$\begin{array}{llll}\text { C } & -4.934357 & 1.385840 & -1.329874\end{array}$

$\begin{array}{llll}\mathrm{H} & -2.795128 & 1.585197 & -1.395203\end{array}$

$\begin{array}{llll}\mathrm{C} & -5.899322 & 1.058772 & 0.839432\end{array}$

$\begin{array}{llll}\mathrm{H} & -4.509031 & 1.007632 & 2.484663\end{array}$

$\begin{array}{llll}\mathrm{C} & -6.058006 & 1.191850 & -0.535766\end{array}$

$\begin{array}{llll}\mathrm{C} & -6.058006 & 1.191850 & -0.535766 \\ \mathrm{H} & -5.043410 & 1.505632 & -2.404866\end{array}$

$\begin{array}{llll}\mathrm{H} & -6.769011 & 0.916157 & 1.475439\end{array}$

$\begin{array}{llll}\mathrm{H} & -7.047126 & 1.155115 & -0.982292\end{array}$

$\begin{array}{llll}\mathrm{N} & 0.077414 & 1.006917 & 1.313887\end{array}$

$\begin{array}{llll}\mathrm{C} & 0.378079 & 1.997702 & 2.364329\end{array}$

$\begin{array}{llll}\mathrm{C} & 0.040395 & 3.412026 & 1.898384\end{array}$

$\begin{array}{llll}\mathrm{H} & -1.024717 & 3.510737 & 1.676761\end{array}$

$\begin{array}{llll}\mathrm{H} & 0.301209 & 4.130042 & 2.685452\end{array}$

$\begin{array}{llll}\mathrm{H} & 0.610136 & 3.675183 & 0.999202\end{array}$

$\begin{array}{llll}\mathrm{C} & 1.866265 & 1.913072 & 2.670635\end{array}$ 


$\begin{array}{lrrr}\mathrm{H} & 2.120075 & 0.927654 & 3.076123 \\ \mathrm{H} & 2.477347 & 2.096831 & 1.780141 \\ \mathrm{H} & 2.136419 & 2.664118 & 3.420509 \\ \mathrm{C} & -0.382564 & 1.657693 & 3.646264 \\ \mathrm{H} & -0.041766 & 2.312573 & 4.457183 \\ \mathrm{H} & -1.459374 & 1.785297 & 3.520453 \\ \mathrm{H} & -0.184672 & 0.619700 & 3.940120 \\ \mathrm{Br} & 1.048238 & -2.081668 & -1.638550 \\ \mathrm{Br} & 1.293431 & -1.964488 & 1.980209\end{array}$

TS2-CM M06/6-311g(d,p)/superfine in PhCF3 Solvent Electronic energy -7317.102910 a.u.

Gibbs free energy $-7316.709391(-7316.704980)$ a.u. 64

\begin{tabular}{|c|c|c|c|}
\hline $\mathrm{Ti}$ & 0.906566 & 0.078778 & -0.256825 \\
\hline $\mathrm{N}$ & 3.126863 & -0.398992 & -0.325337 \\
\hline $\mathrm{N}$ & 1.199387 & 0.074178 & 2.024607 \\
\hline $\mathrm{N}$ & -1.023255 & 0.677569 & 0.056526 \\
\hline $\mathrm{C}$ & -1.850625 & 1.815099 & -0.188796 \\
\hline $\mathrm{C}$ & -1.961144 & 2.795492 & 0.789106 \\
\hline $\mathrm{C}$ & -2.791358 & 3.886176 & 0.575666 \\
\hline $\mathrm{C}$ & -2.554290 & 1.929482 & -1.382465 \\
\hline $\mathrm{C}$ & -3.383112 & 3.023233 & -1.587238 \\
\hline $\mathrm{C}$ & -3.505850 & 4.002383 & -0.610108 \\
\hline $\mathrm{H}$ & -1.408395 & 2.689109 & 1.716727 \\
\hline $\mathrm{H}$ & -2.881084 & 4.649512 & 1.342896 \\
\hline $\mathrm{H}$ & -3.933867 & 3.110031 & -2.519044 \\
\hline $\mathrm{H}$ & -4.155780 & 4.856659 & -0.773340 \\
\hline $\mathrm{H}$ & -2.447198 & 1.162726 & -2.144697 \\
\hline $\mathrm{C}$ & 0.926050 & 1.135217 & 2.796076 \\
\hline $\mathrm{C}$ & 1.522883 & -1.073633 & 2.637259 \\
\hline $\mathrm{C}$ & 0.952823 & 1.086291 & 4.178870 \\
\hline $\mathrm{C}$ & 1.588030 & -1.204269 & 4.011725 \\
\hline $\mathrm{C}$ & 1.290956 & -0.104051 & 4.801390 \\
\hline $\mathrm{H}$ & 0.701837 & 2.057290 & 2.268309 \\
\hline $\mathrm{H}$ & 0.716315 & 1.976873 & 4.750197 \\
\hline $\mathrm{H}$ & 1.324899 & -0.173830 & 5.883992 \\
\hline $\mathrm{H}$ & 1.863743 & -2.157705 & 4.447931 \\
\hline $\mathrm{H}$ & 1.740688 & -1.916533 & 1.990458 \\
\hline $\mathrm{C}$ & 3.988958 & 0.036531 & 0.604903 \\
\hline $\mathrm{C}$ & 5.341610 & -0.244384 & 0.565743 \\
\hline $\mathrm{C}$ & 5.839067 & -0.998691 & -0.485480 \\
\hline $\mathrm{C}$ & 4.959160 & -1.439057 & -1.460471 \\
\hline $\mathrm{C}$ & 3.618925 & -1.119023 & -1.343326 \\
\hline $\mathrm{H}$ & 3.575749 & 0.646653 & 1.400844 \\
\hline $\mathrm{H}$ & 5.989533 & 0.134161 & 1.348046 \\
\hline $\mathrm{H}$ & 6.897254 & -1.232151 & -0.547586 \\
\hline $\mathrm{H}$ & 2.905457 & -1.430893 & -2.099675 \\
\hline $\mathrm{H}$ & 5.297905 & -2.021388 & -2.309741 \\
\hline $\mathrm{C}$ & -1.501957 & -0.500940 & -0.132656 \\
\hline $\mathrm{N}$ & -2.406382 & -1.285258 & -0.331738 \\
\hline $\mathrm{C}$ & -3.753691 & -1.372380 & 0.013602 \\
\hline $\mathrm{C}$ & -4.400215 & -0.387568 & 0.766359 \\
\hline $\mathrm{C}$ & -4.464535 & -2.494752 & -0.412144 \\
\hline $\mathrm{C}$ & -5.743380 & -0.531326 & 1.076400 \\
\hline $\mathrm{H}$ & -3.849220 & 0.486432 & 1.103203 \\
\hline $\mathrm{C}$ & -5.808053 & -2.626522 & -0.098079 \\
\hline $\mathrm{H}$ & -3.947539 & -3.253159 & -0.993159 \\
\hline $\mathrm{C}$ & -6.452607 & -1.646712 & 0.646445 \\
\hline $\mathrm{H}$ & -6.240792 & 0.238737 & 1.658644 \\
\hline $\mathrm{H}$ & -6.354514 & -3.501787 & -0.436414 \\
\hline $\mathrm{H}$ & -7.504945 & -1.751188 & 0.891957 \\
\hline $\mathrm{N}$ & 0.303053 & -1.551776 & -0.212654 \\
\hline $\mathrm{C}$ & 0.124407 & -2.993011 & -0.335211 \\
\hline $\mathrm{C}$ & -0.694837 & -3.576227 & 0.818777 \\
\hline $\mathrm{H}$ & -1.730603 & -3.232861 & 0.813778 \\
\hline
\end{tabular}

$\begin{array}{lrrr}\mathrm{H} & -0.702783 & -4.670240 & 0.742511 \\ \mathrm{H} & -0.247358 & -3.309703 & 1.783268 \\ \mathrm{C} & 1.516972 & -3.628766 & -0.288826 \\ \mathrm{H} & 2.132681 & -3.295618 & -1.128967 \\ \mathrm{H} & 2.045298 & -3.397828 & 0.642389 \\ \mathrm{H} & 1.418052 & -4.718805 & -0.356343 \\ \mathrm{C} & -0.494016 & -3.339009 & -1.691196 \\ \mathrm{H} & -0.533319 & -4.428714 & -1.812554 \\ \mathrm{H} & -1.504832 & -2.939914 & -1.791738 \\ \mathrm{H} & 0.118608 & -2.920506 & -2.497546 \\ \mathrm{Br} & 0.792818 & 0.293257 & -2.781047 \\ \mathrm{Br} & 1.736070 & 2.604570 & -0.127580\end{array}$

IM3-CM M06/6-311g(d,p)/superfine in PhCF3 Solvent Electronic energy -6706.518776 a.u.

Gibbs free energy -6706.296028 (-6706.293720) a.u. 39

$\begin{array}{lll}-0.269834 & 0.478767 & -0.070540\end{array}$

$\begin{array}{llll}\mathrm{N} & 2.137118 & 0.050925 & 0.100461\end{array}$

$\begin{array}{llll}\mathrm{N} & -1.927819 & 0.412322 & -0.214646\end{array}$

$\begin{array}{llll}\text { C } & 2.689652 & -0.731304 & -0.835399\end{array}$

$\begin{array}{llll}\text { C } & 4.051981 & -0.939144 & -0.944340\end{array}$

$\begin{array}{llll}\mathrm{C} & 4.895119 & -0.304873 & -0.043675\end{array}$

$\begin{array}{llll}\mathrm{C} & 4.336247 & 0.510156 & 0.926171\end{array}$

$\begin{array}{llll}\mathrm{C} & 2.959014 & 0.658474 & 0.961541\end{array}$

$\begin{array}{llll}\mathrm{H} & 2.010365 & -1.209667 & -1.537359\end{array}$

$\mathrm{H} \quad 4.439183 \quad-1.584955 \quad-1.724501$

$\begin{array}{llll}\mathrm{H} & 5.970240 & -0.443744 & -0.100026\end{array}$

$\begin{array}{llll}\mathrm{H} & 2.484349 & 1.288866 & 1.709060\end{array}$

$\begin{array}{llll}\mathrm{H} & 4.951882 & 1.030248 & 1.651709\end{array}$

$\begin{array}{llll}\mathrm{Br} & 0.368809 & 1.741586 & -2.107333\end{array}$

$\mathrm{Br} \quad-0.148185 \quad 1.574052 \quad 2.152724$

$\begin{array}{llll}\mathrm{N} & -0.182975 & -1.696764 & 0.000661\end{array}$

$\begin{array}{llll}\text { C } & -0.612114 & -2.415801 & -1.045644\end{array}$

$\begin{array}{llll}\mathrm{C} & 0.153202 & -2.332069 & 1.129330\end{array}$

$\begin{array}{llll}\text { C } & -0.712436 & -3.792617 & -1.002864\end{array}$

$\mathrm{H} \quad-0.888715 \quad-1.856495 \quad-1.936347$

$\begin{array}{llll}\mathrm{C} & 0.053471 & -3.705121 & 1.260419\end{array}$

$\mathrm{H} \quad 0.507172 \quad-1.713937 \quad 1.950787$

$\begin{array}{llll}\mathrm{C} & -0.383462 & -4.448358 & 0.175137\end{array}$

$\begin{array}{llll}\mathrm{H} & -1.053917 & -4.334925 & -1.876852\end{array}$

$\mathrm{H} \quad \begin{array}{llll}-1.322512 & -4.176605 & 2.198396\end{array}$

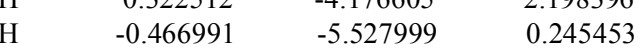

$\begin{array}{llll}\mathrm{C} & -3.350447 & 0.223788 & -0.131194\end{array}$

$\begin{array}{llll}\text { C } & -3.907181 & -0.062779 & -1.523372\end{array}$

$\mathrm{H} \quad-3.476139 \quad-0.984603 \quad-1.931644$

$\begin{array}{llll}-3.476139 & -0.984603 & -1.931644\end{array}$

$\begin{array}{llll}\mathrm{H} & -3.665095 & 0.759457 & -2.206643\end{array}$

$\begin{array}{llll}\mathrm{C} & -3.976206 & 1.499308 & 0.428600\end{array}$

$\begin{array}{llll}\mathrm{C} & -3.976206 & 1.499308 & 0.428600 \\ \mathrm{H} & -5.064931 & 1.393978 & 0.517627\end{array}$

$\begin{array}{llll}\mathrm{H} & -5.064931 & 1.393978 & 0.517627 \\ \mathrm{H} & -3.563599 & 1.723075 & 1.418544\end{array}$

$\begin{array}{llll}\mathrm{H} & -3.761280 & 2.348912 & -0.229401\end{array}$

$\begin{array}{llll}\text { C } & -3.632744 & -0.949623 & 0.806341\end{array}$

$\mathrm{H} \quad-3.188415 \quad-0.759125 \quad 1.791041$

$\begin{array}{llll}\mathrm{H} & -4.712096 & -1.101942 & 0.933785\end{array}$

$\begin{array}{llll}\mathrm{H} & -3.200817 & -1.877504 & 0.410864\end{array}$ 
III. Carbodiimide formation pathway with tert-butyl imido Ti starting catalyst

\section{L=pyridine/pyridine (Figure S71, yellow)}

IM0 M06/6-311g(d,p)/superfine in PhCF3 Solvent Electronic energy -6706.532645 a.u.

Gibbs free energy -6706.309647 (-6706.306883) a.u. 39

$\begin{array}{lccc}\mathrm{Ti} & 0.402931 & -0.120049 & 0.284863 \\ \mathrm{~N} & -1.453584 & -1.286562 & -0.154975 \\ \mathrm{~N} & -1.125035 & 1.492709 & 0.124356 \\ \mathrm{~N} & 1.077897 & -0.031748 & -1.231577 \\ \mathrm{C} & 2.028097 & 0.100637 & -2.312328 \\ \mathrm{C} & -1.306098 & 2.176652 & -1.011198 \\ \mathrm{C} & -1.880570 & 1.801240 & 1.185649 \\ \mathrm{C} & -2.243421 & 3.188420 & -1.125537 \\ \mathrm{C} & -2.840832 & 2.794228 & 1.154168 \\ \mathrm{C} & -3.025337 & 3.502391 & -0.025254 \\ \mathrm{H} & -0.670863 & 1.891684 & -1.844647 \\ \mathrm{H} & -2.352281 & 3.716712 & -2.065960 \\ \mathrm{H} & -3.768420 & 4.291143 & -0.083349 \\ \mathrm{H} & -3.427134 & 3.007311 & 2.040310 \\ \mathrm{H} & -1.696520 & 1.233243 & 2.095525 \\ \mathrm{C} & -2.205389 & -1.778513 & 0.838206 \\ \mathrm{C} & -3.382319 & -2.466216 & 0.613990 \\ \mathrm{C} & -3.798690 & -2.662244 & -0.694221 \\ \mathrm{C} & -3.023647 & -2.157876 & -1.726231 \\ \mathrm{C} & -1.860781 & -1.475503 & -1.416350 \\ \mathrm{H} & -1.841965 & -1.618693 & 1.850425 \\ \mathrm{H} & -3.953790 & -2.845136 & 1.454129 \\ \mathrm{H} & -4.715247 & -3.203300 & -0.905436 \\ \mathrm{H} & -1.220843 & -1.062301 & -2.190215 \\ \mathrm{H} & -3.307907 & -2.289778 & -2.763607 \\ \mathrm{Br} & 1.727340 & 1.524052 & 1.638245 \\ \mathrm{Br} & 1.284227 & -2.206932 & 1.370107 \\ \mathrm{C} & 1.363858 & -0.307710 & -3.624514 \\ \mathrm{H} & 2.064934 & -0.199117 & -4.461146 \\ \mathrm{H} & 1.037921 & -1.353555 & -3.584737 \\ \mathrm{H} & 0.488433 & 0.320516 & -3.831908 \\ \mathrm{C} & 3.221999 & -0.806729 & -2.026975 \\ \mathrm{H} & 2.897588 & -1.850553 & -1.942397 \\ \mathrm{H} & 3.968969 & -0.733665 & -2.828011 \\ \mathrm{H} & 3.693703 & -0.522188 & -1.078563 \\ \mathrm{H} & 2.490008 & 1.553692 & -2.389695 \\ \mathrm{H} & 1.647835 & 2.222093 & -2.607139 \\ \mathrm{H} & 3.930006 & 1.862412 & -1.435408 \\ \mathrm{H} & & 1.679455 & -3.180046\end{array}$

IM1 M06/6-311g(d,p)/superfine in PhCF3 Solvent Electronic energy -6957.098716 a.u.

Gibbs free energy -6956.759444 (-6956.758167) a.u. 54

$\begin{array}{lrrr}\mathrm{Ti} & 0.319305 & -0.354352 & -0.021551 \\ \mathrm{~N} & 0.521060 & 2.093025 & -0.149475 \\ \mathrm{~N} & 2.535999 & -0.361139 & 0.282722 \\ \mathrm{~N} & 0.007118 & -1.998896 & 0.014937 \\ \mathrm{C} & -0.498362 & -3.342307 & -0.012300 \\ \mathrm{C} & 3.263153 & -1.261372 & -0.394231 \\ \mathrm{C} & 3.171849 & 0.465317 & 1.123767 \\ \mathrm{C} & 4.635010 & -1.363509 & -0.261728 \\ \mathrm{C} & 4.541549 & 0.429544 & 1.311404 \\ \mathrm{C} & 5.287845 & -0.501713 & 0.606649 \\ \mathrm{H} & 2.711900 & -1.912453 & -1.066053 \\ \mathrm{H} & 5.175837 & -2.110665 & -0.831222 \\ \mathrm{H} & 6.364278 & -0.557577 & 0.734654\end{array}$

\begin{tabular}{|c|c|c|c|}
\hline $\mathrm{H}$ & 5.007132 & 1.121800 & 2.003508 \\
\hline $\mathrm{H}$ & 2.548668 & 1.169177 & 1.668132 \\
\hline $\mathrm{C}$ & -0.349761 & 2.904862 & 0.460104 \\
\hline $\mathrm{C}$ & -0.308636 & 4.284474 & 0.347396 \\
\hline $\mathrm{C}$ & 0.694254 & 4.860879 & -0.416040 \\
\hline $\mathrm{C}$ & 1.609787 & 4.030561 & -1.043363 \\
\hline $\mathrm{C}$ & 1.478227 & 2.660649 & -0.891768 \\
\hline $\mathrm{H}$ & -1.105364 & 2.424421 & 1.077174 \\
\hline $\mathrm{H}$ & -1.049973 & 4.889466 & 0.857854 \\
\hline $\mathrm{H}$ & 0.761337 & 5.939255 & -0.520948 \\
\hline $\mathrm{H}$ & 2.161891 & 1.983416 & -1.396619 \\
\hline $\mathrm{H}$ & 2.414116 & 4.430984 & -1.650656 \\
\hline $\mathrm{C}$ & -1.868988 & 0.067665 & -0.226345 \\
\hline $\mathrm{N}$ & -3.018815 & 0.210820 & -0.208704 \\
\hline $\mathrm{C}$ & -4.443309 & 0.420449 & -0.045179 \\
\hline $\mathrm{C}$ & -5.165598 & -0.752731 & -0.688083 \\
\hline $\mathrm{H}$ & -4.927192 & -0.820119 & -1.754207 \\
\hline $\mathrm{H}$ & -4.887787 & -1.694159 & -0.203456 \\
\hline $\mathrm{H}$ & -6.245499 & -0.610996 & -0.579768 \\
\hline $\mathrm{C}$ & -4.795497 & 1.734207 & -0.725516 \\
\hline $\mathrm{H}$ & -4.231636 & 2.562364 & -0.283094 \\
\hline $\mathrm{H}$ & -4.574346 & 1.689941 & -1.796651 \\
\hline $\mathrm{H}$ & -5.864441 & 1.930048 & -0.596704 \\
\hline $\mathrm{C}$ & -4.703968 & 0.483177 & 1.453036 \\
\hline $\mathrm{H}$ & -4.398401 & -0.449096 & 1.939550 \\
\hline $\mathrm{H}$ & -4.151470 & 1.312373 & 1.907965 \\
\hline $\mathrm{H}$ & -5.773771 & 0.636842 & 1.627003 \\
\hline $\mathrm{Br}$ & -0.087304 & 0.133458 & 2.480023 \\
\hline $\mathrm{Br}$ & 0.543966 & -0.152158 & -2.571043 \\
\hline $\mathrm{C}$ & -1.411278 & -3.553015 & 1.193787 \\
\hline $\mathrm{H}$ & -1.834538 & -4.566009 & 1.195026 \\
\hline $\mathrm{H}$ & -0.855484 & -3.403039 & 2.125870 \\
\hline $\mathrm{H}$ & -2.236284 & -2.829456 & 1.176867 \\
\hline $\mathrm{C}$ & -1.281141 & -3.550488 & -1.307269 \\
\hline $\mathrm{H}$ & -2.126132 & -2.852626 & -1.360424 \\
\hline $\mathrm{H}$ & -0.638146 & -3.361824 & -2.173809 \\
\hline $\mathrm{H}$ & -1.670820 & -4.574800 & -1.371355 \\
\hline $\mathrm{C}$ & 0.675139 & -4.318569 & 0.045308 \\
\hline $\mathrm{H}$ & 1.278313 & -4.139801 & 0.943199 \\
\hline $\mathrm{H}$ & 0.320264 & -5.356809 & 0.066726 \\
\hline $\mathrm{H}$ & 1.320463 & -4.195602 & -0.832877 \\
\hline
\end{tabular}

TS1 M06/6-311g(d,p)/superfine in PhCF3 Solvent Electronic energy -6957.064585 a.u. Gibbs free energy -6956.727906 (-6956.723721) a.u. 54

$\begin{array}{lrrr}\mathrm{Ti} & 0.214963 & -0.266877 & -0.006302 \\ \mathrm{~N} & 0.787627 & 2.026903 & -0.058581 \\ \mathrm{~N} & 2.437275 & -0.755677 & 0.051369 \\ \mathrm{~N} & -0.861486 & -1.625385 & 0.034094 \\ \mathrm{C} & -1.597643 & -2.874995 & 0.113696 \\ \mathrm{C} & 2.833124 & -1.873232 & -0.572535 \\ \mathrm{C} & 3.352506 & -0.052860 & 0.731402 \\ \mathrm{C} & 4.138927 & -2.326212 & -0.540791 \\ \mathrm{C} & 4.682003 & -0.425460 & 0.796965 \\ \mathrm{C} & 5.083416 & -1.585705 & 0.152515 \\ \mathrm{H} & 2.069075 & -2.416928 & -1.121891 \\ \mathrm{H} & 4.403347 & -3.241920 & -1.057047 \\ \mathrm{H} & 6.118579 & -1.909464 & 0.192043 \\ \mathrm{H} & 5.384348 & 0.184798 & 1.353173 \\ \mathrm{H} & 2.995744 & 0.833818 & 1.247158 \\ \mathrm{C} & 0.115824 & 2.898089 & 0.704827 \\ \mathrm{C} & 0.351877 & 4.261065 & 0.683502 \\ \mathrm{C} & 1.341592 & 4.753304 & -0.152845 \\ \mathrm{C} & 2.050393 & 3.859900 & -0.940200 \\ \mathrm{C} & 1.736005 & 2.514222 & -0.868932\end{array}$




\begin{tabular}{lrrr}
$\mathrm{H}$ & -0.637671 & 2.477718 & 1.364834 \\
$\mathrm{H}$ & -0.231976 & 4.917991 & 1.318415 \\
$\mathrm{H}$ & 1.556717 & 5.816619 & -0.190527 \\
$\mathrm{H}$ & 2.254126 & 1.791741 & -1.493130 \\
$\mathrm{H}$ & 2.834652 & 4.193869 & -1.610242 \\
$\mathrm{C}$ & -1.796310 & -0.102238 & -0.034317 \\
$\mathrm{~N}$ & -3.007998 & -0.192971 & -0.054113 \\
$\mathrm{C}$ & -3.982609 & 0.911172 & -0.104480 \\
$\mathrm{C}$ & -5.189406 & 0.395715 & -0.873616 \\
$\mathrm{H}$ & -4.910039 & 0.135177 & -1.900978 \\
$\mathrm{H}$ & -5.598941 & -0.499093 & -0.391177 \\
$\mathrm{H}$ & -5.973205 & 1.160465 & -0.913238 \\
$\mathrm{C}$ & -3.402906 & 2.138947 & -0.790226 \\
$\mathrm{H}$ & -2.556560 & 2.546925 & -0.226746 \\
$\mathrm{H}$ & -3.054911 & 1.891864 & -1.799951 \\
$\mathrm{H}$ & -4.168118 & 2.919310 & -0.871037 \\
$\mathrm{C}$ & -4.366810 & 1.226294 & 1.334326 \\
$\mathrm{H}$ & -4.766010 & 0.336572 & 1.834230 \\
$\mathrm{H}$ & -3.495814 & 1.576488 & 1.900721 \\
$\mathrm{H}$ & -5.134138 & 2.008620 & 1.356150 \\
$\mathrm{Br}$ & 0.401963 & -0.024307 & 2.518342 \\
$\mathrm{Br}$ & 0.446938 & -0.159218 & -2.530224 \\
$\mathrm{C}$ & -2.441022 & -2.934758 & 1.384469 \\
$\mathrm{H}$ & -1.812382 & -2.752686 & 2.263305 \\
$\mathrm{H}$ & -3.243212 & -2.192686 & 1.370769 \\
$\mathrm{H}$ & -2.892402 & -3.929620 & 1.479725 \\
$\mathrm{C}$ & -2.447542 & -3.090031 & -1.135847 \\
$\mathrm{H}$ & -1.825256 & -3.004245 & -2.034051 \\
$\mathrm{H}$ & -2.887686 & -4.094283 & -1.113622 \\
$\mathrm{H}$ & -3.257662 & -2.359410 & -1.203643 \\
$\mathrm{C}$ & -0.519430 & -3.957047 & 0.179571 \\
$\mathrm{H}$ & 0.090735 & -3.947359 & -0.731364 \\
$\mathrm{H}$ & 0.138209 & -3.789168 & 1.041050 \\
$\mathrm{H}$ & -0.980142 & -4.947568 & 0.277281 \\
& & & \\
\hline
\end{tabular}

IM2 M06/6-311g(d,p)/superfine in PhCF3 Solvent Electronic energy -6957.088807 a.u.

Gibbs free energy -6956.745763 (-6956.743967) a.u. 54

$\begin{array}{lrrr}\mathrm{Ti} & -0.217606 & -0.367153 & 0.015497 \\ \mathrm{~N} & -0.272735 & 1.831549 & -0.031637 \\ \mathrm{~N} & -2.543755 & -0.123629 & 0.158026 \\ \mathrm{~N} & 1.230510 & -1.535137 & -0.120797 \\ \mathrm{C} & 1.709742 & -2.921974 & -0.198957 \\ \mathrm{C} & -3.203857 & -1.235088 & 0.505439 \\ \mathrm{C} & -3.263556 & 0.929143 & -0.243076 \\ \mathrm{C} & -4.581821 & -1.337057 & 0.472988 \\ \mathrm{C} & -4.646363 & 0.919966 & -0.291308 \\ \mathrm{C} & -5.320443 & -0.234543 & 0.072310 \\ \mathrm{H} & -2.601569 & -2.083102 & 0.824987 \\ \mathrm{H} & -5.059875 & -2.266407 & 0.760704 \\ \mathrm{H} & -6.404427 & -0.276685 & 0.039996 \\ \mathrm{H} & -5.177836 & 1.806761 & -0.617558 \\ \mathrm{H} & -2.713944 & 1.815246 & -0.548505 \\ \mathrm{C} & -0.003391 & 2.509849 & -1.158986 \\ \mathrm{C} & -0.065158 & 3.888100 & -1.234158 \\ \mathrm{C} & -0.418864 & 4.607170 & -0.102793 \\ \mathrm{C} & -0.701058 & 3.914623 & 1.063949 \\ \mathrm{C} & -0.620148 & 2.535139 & 1.059794 \\ \mathrm{H} & 0.268673 & 1.917921 & -2.027314 \\ \mathrm{H} & 0.163758 & 4.381519 & -2.171770 \\ \mathrm{H} & -0.473260 & 5.690575 & -0.130620 \\ \mathrm{H} & -0.837443 & 1.960440 & 1.954982 \\ \mathrm{H} & -0.983672 & 4.429315 & 1.975019 \\ \mathrm{C} & 1.876233 & -0.373566 & -0.053162 \\ \mathrm{~N} & 3.127463 & -0.125884 & -0.051753\end{array}$

$\begin{array}{lccc}\mathrm{C} & 3.685826 & 1.226340 & 0.066138 \\ \mathrm{C} & 5.152631 & 1.043572 & 0.444845 \\ \mathrm{H} & 5.237660 & 0.537646 & 1.414026 \\ \mathrm{H} & 5.666956 & 0.428554 & -0.302511 \\ \mathrm{H} & 5.667344 & 2.009762 & 0.513502 \\ \mathrm{C} & 3.005681 & 2.061723 & 1.144532 \\ \mathrm{H} & 1.975585 & 2.304618 & 0.873924 \\ \mathrm{H} & 2.987941 & 1.517568 & 2.096943 \\ \mathrm{H} & 3.545757 & 3.004338 & 1.299027 \\ \mathrm{C} & 3.610432 & 1.934507 & -1.282286 \\ \mathrm{H} & 4.118368 & 1.343126 & -2.053184 \\ \mathrm{H} & 2.569464 & 2.071271 & -1.594648 \\ \mathrm{H} & 4.087556 & 2.922061 & -1.237251 \\ \mathrm{Br} & -0.861376 & -0.725488 & -2.379998 \\ \mathrm{Br} & -0.450009 & -0.713753 & 2.478530 \\ \mathrm{C} & 0.499468 & -3.841174 & -0.152636 \\ \mathrm{H} & 0.811621 & -4.889398 & -0.224495 \\ \mathrm{H} & -0.046458 & -3.714362 & 0.790485 \\ \mathrm{H} & -0.183290 & -3.629555 & -0.984463 \\ \mathrm{C} & 2.460526 & -3.094877 & -1.513022 \\ \mathrm{H} & 2.818538 & -4.127169 & -1.604837 \\ \mathrm{H} & 1.802295 & -2.878199 & -2.361867 \\ \mathrm{H} & 3.321376 & -2.421731 & -1.559983 \\ \mathrm{C} & 2.622231 & -3.189746 & 0.990697 \\ \mathrm{H} & 2.974184 & -4.227871 & 0.961335 \\ \mathrm{H} & 3.489001 & -2.523334 & 0.974204 \\ \mathrm{H} & 2.082465 & -3.033031 & 1.931576\end{array}$

TS2 M06/6-311g(d,p)/superfine in PhCF3 Solvent Electronic energy -6957.061713 a.u. Gibbs free energy -6956.722033 (-6956.719033) a.u. 54

$\begin{array}{lrrr}\mathrm{Ti} & -0.455707 & -0.427990 & -0.001003 \\ \mathrm{~N} & -0.178507 & 1.570798 & -0.296932 \\ \mathrm{~N} & -2.636311 & 0.107144 & 0.379347 \\ \mathrm{~N} & 1.374375 & -1.345727 & -0.374127 \\ \mathrm{C} & 1.930087 & -2.742420 & -0.392750 \\ \mathrm{C} & -3.422952 & -0.678171 & 1.129312 \\ \mathrm{C} & -3.225166 & 1.099206 & -0.304883 \\ \mathrm{C} & -4.790603 & -0.506898 & 1.227269 \\ \mathrm{C} & -4.587529 & 1.338436 & -0.266612 \\ \mathrm{C} & -5.388573 & 0.522205 & 0.514735 \\ \mathrm{H} & -2.926026 & -1.475964 & 1.673624 \\ \mathrm{H} & -5.372100 & -1.177292 & 1.850078 \\ \mathrm{H} & -6.460749 & 0.682877 & 0.566653 \\ \mathrm{H} & -5.004351 & 2.155429 & -0.844843 \\ \mathrm{H} & -2.579986 & 1.723127 & -0.916746 \\ \mathrm{C} & 0.113803 & 2.083025 & -1.528814 \\ \mathrm{C} & 0.129805 & 3.433122 & -1.797850 \\ \mathrm{C} & -0.108175 & 4.351340 & -0.779257 \\ \mathrm{C} & -0.365870 & 3.843747 & 0.490596 \\ \mathrm{C} & -0.408807 & 2.482486 & 0.693892 \\ \mathrm{H} & 0.322979 & 1.359305 & -2.311085 \\ \mathrm{H} & 0.350099 & 3.758254 & -2.809545 \\ \mathrm{H} & -0.087329 & 5.419060 & -0.966545 \\ \mathrm{H} & -0.648675 & 2.073630 & 1.671770 \\ \mathrm{H} & -0.556492 & 4.501414 & 1.332544 \\ \mathrm{C} & 2.083766 & -0.317931 & -0.367112 \\ \mathrm{~N} & 2.972245 & 0.490678 & -0.565430 \\ \mathrm{C} & 3.662221 & 1.473717 & 0.282274 \\ \mathrm{C} & 5.119913 & 1.032927 & 0.352421 \\ \mathrm{H} & 5.207031 & 0.047740 & 0.823990 \\ \mathrm{H} & 5.554593 & 0.976550 & -0.651208 \\ \mathrm{H} & 5.701264 & 1.750086 & 0.943169 \\ \mathrm{C} & 3.062149 & 1.516390 & 1.677916 \\ \mathrm{H} & 2.009007 & 1.816640 & 1.645586\end{array}$




$\begin{array}{lccc}\mathrm{H} & 3.129128 & 0.535720 & 2.163969 \\ \mathrm{H} & 3.605156 & 2.241437 & 2.294962 \\ \mathrm{C} & 3.568521 & 2.835216 & -0.388533 \\ \mathrm{H} & 3.942944 & 2.782969 & -1.416817 \\ \mathrm{H} & 2.533063 & 3.189884 & -0.414973 \\ \mathrm{H} & 4.170339 & 3.567078 & 0.162256 \\ \mathrm{Br} & -1.306506 & -1.289938 & -2.192629 \\ \mathrm{Br} & -0.262333 & -0.878717 & 2.444754 \\ \mathrm{C} & 3.010292 & -2.857206 & 0.670083 \\ \mathrm{H} & 3.406295 & -3.878817 & 0.691301 \\ \mathrm{H} & 3.844935 & -2.177434 & 0.462320 \\ \mathrm{H} & 2.605478 & -2.622915 & 1.661286 \\ \mathrm{C} & 2.499332 & -2.993787 & -1.778765 \\ \mathrm{H} & 2.900532 & -4.012185 & -1.840466 \\ \mathrm{H} & 1.722692 & -2.879151 & -2.542404 \\ \mathrm{H} & 3.312757 & -2.293605 & -2.001354 \\ \mathrm{C} & 0.787807 & -3.694813 & -0.095696 \\ \mathrm{H} & 1.154784 & -4.726926 & -0.101424 \\ \mathrm{H} & 0.356734 & -3.493393 & 0.891888 \\ \mathrm{H} & -0.001918 & -3.608585 & -0.849652\end{array}$

IM3 M06/6-311g(d,p)/superfine in PhCF3 Solvent Same IM3 as SI part I where $\mathrm{L}=$ pyridine/pyridine 
IV. Carbodiimide Metathesis pathway with various ligand combinations and isomers for the determination of most likely pathways to result in symmetric and unsymmetric carbodiimide products (Figure S72).

Pathway 1 (Red)

Same pathway as carbodiimide metathesis (red) in III above

Pathway 2 (Orange)

Same start in SI Part I where L=pyridine/pyridine for IM0 geometry

TS1-CM M06/6-311g(d,p)/superfine in PhCF3 Solvent Electronic energy -7390.881861 a.u.

Gibbs free energy -7390.516424 (-7390.513428) a.u. 62

\begin{tabular}{|c|c|c|c|}
\hline $\mathrm{Ti}$ & -0.611032 & -0.884247 & -0.088909 \\
\hline $\mathrm{N}$ & -2.951150 & -0.573755 & 0.323418 \\
\hline $\mathrm{N}$ & -0.492659 & 0.367607 & 1.814486 \\
\hline $\mathrm{N}$ & 1.116052 & -0.906747 & -0.317278 \\
\hline $\mathrm{C}$ & 2.384779 & -1.369996 & -0.588953 \\
\hline $\mathrm{C}$ & 3.242372 & -1.748171 & 0.452477 \\
\hline $\mathrm{C}$ & 4.507404 & -2.238791 & 0.173985 \\
\hline $\mathrm{C}$ & 2.826621 & -1.498045 & -1.912548 \\
\hline $\mathrm{C}$ & 4.095136 & -1.985889 & -2.180924 \\
\hline $\mathrm{C}$ & 4.942537 & -2.354380 & -1.141831 \\
\hline $\mathrm{H}$ & 2.899293 & -1.646782 & 1.478572 \\
\hline $\mathrm{H}$ & 5.161999 & -2.529628 & 0.990783 \\
\hline $\mathrm{H}$ & 4.425671 & -2.081797 & -3.211435 \\
\hline $\mathrm{H}$ & 5.936625 & -2.734910 & -1.356600 \\
\hline $\mathrm{H}$ & 2.155286 & -1.214531 & -2.718224 \\
\hline $\mathrm{C}$ & 0.396073 & 0.021952 & 2.758250 \\
\hline $\mathrm{C}$ & -1.166896 & 1.513883 & 1.979363 \\
\hline $\mathrm{C}$ & 0.641858 & 0.797117 & 3.876419 \\
\hline $\mathrm{C}$ & -0.975910 & 2.350287 & 3.064636 \\
\hline $\mathrm{C}$ & -0.053125 & 1.986781 & 4.032805 \\
\hline $\mathrm{H}$ & 0.921587 & -0.914333 & 2.601468 \\
\hline $\mathrm{H}$ & 1.371131 & 0.465704 & 4.606934 \\
\hline $\mathrm{H}$ & 0.120167 & 2.619378 & 4.897486 \\
\hline $\mathrm{H}$ & -1.548646 & 3.267646 & 3.140468 \\
\hline $\mathrm{H}$ & -1.888997 & 1.772354 & 1.210388 \\
\hline $\mathrm{C}$ & -3.451759 & -0.690212 & 1.561796 \\
\hline $\mathrm{C}$ & -4.787835 & -0.496626 & 1.859535 \\
\hline $\mathrm{C}$ & -5.660105 & -0.165766 & 0.833548 \\
\hline $\mathrm{C}$ & -5.158261 & -0.056019 & -0.452500 \\
\hline $\mathrm{C}$ & -3.807316 & -0.275036 & -0.660609 \\
\hline $\mathrm{H}$ & -2.748687 & -0.959998 & 2.344334 \\
\hline $\mathrm{H}$ & -5.132175 & -0.608612 & 2.881482 \\
\hline $\mathrm{H}$ & -6.714962 & -0.005241 & 1.033157 \\
\hline $\mathrm{H}$ & -3.390352 & -0.233913 & -1.661185 \\
\hline $\mathrm{H}$ & -5.798557 & 0.187231 & -1.292986 \\
\hline $\mathrm{C}$ & 0.868434 & 0.984541 & -0.983715 \\
\hline $\mathrm{N}$ & 1.943506 & 1.528628 & -1.203567 \\
\hline $\mathrm{C}$ & 3.087338 & 1.688996 & -0.427615 \\
\hline $\mathrm{C}$ & 2.989033 & 1.834779 & 0.958614 \\
\hline $\mathrm{C}$ & 4.337336 & 1.745031 & -1.041369 \\
\hline $\mathrm{C}$ & 4.133253 & 1.998341 & 1.721802 \\
\hline $\mathrm{H}$ & 2.006563 & 1.813531 & 1.424809 \\
\hline $\mathrm{C}$ & 5.476784 & 1.908780 & -0.268931 \\
\hline $\mathrm{H}$ & 4.398464 & 1.640165 & -2.120598 \\
\hline $\mathrm{C}$ & 5.382694 & 2.029577 & 1.112941 \\
\hline $\mathrm{H}$ & 4.046843 & 2.102664 & 2.800153 \\
\hline $\mathrm{H}$ & 6.449226 & 1.938709 & -0.751457 \\
\hline $\mathrm{H}$ & 6.279459 & 2.154440 & 1.711877 \\
\hline $\mathrm{N}$ & -0.408771 & 1.009365 & -1.051775 \\
\hline
\end{tabular}

$\begin{array}{llll}\mathrm{Br} & -1.273729 & -2.002694 & -2.233705 \\ \mathrm{Br} & -0.792630 & -2.925309 & 1.360711 \\ \mathrm{C} & -1.074139 & 2.224716 & -1.378865 \\ \mathrm{C} & -0.716444 & 3.434580 & -0.787109 \\ \mathrm{C} & -2.104721 & 2.185030 & -2.311928 \\ \mathrm{C} & -1.404522 & 4.592574 & -1.118754 \\ \mathrm{H} & 0.096560 & 3.465810 & -0.066093 \\ \mathrm{C} & -2.788405 & 3.347703 & -2.637293 \\ \mathrm{H} & -2.340196 & 1.243708 & -2.798591 \\ \mathrm{C} & -2.444857 & 4.552772 & -2.038700 \\ \mathrm{H} & -1.124305 & 5.532769 & -0.653197 \\ \mathrm{H} & -3.588079 & 3.311198 & -3.371035 \\ \mathrm{H} & -2.981622 & 5.461277 & -2.293889\end{array}$

IM2-CM M06/6-311g(d,p)/superfine in PhCF3 Solvent Electronic energy -7390.920431 a.u.

Gibbs free energy -7390.552748 (-7390.548752) a.u. 62

\begin{tabular}{|c|c|c|c|}
\hline $\mathrm{Ti}$ & -0.714866 & -0.667583 & -0.335240 \\
\hline $\mathrm{N}$ & -2.947251 & -0.341545 & -0.453372 \\
\hline $\mathrm{N}$ & -1.212997 & -0.896126 & 1.877117 \\
\hline $\mathrm{N}$ & 1.186246 & -0.352677 & -0.001724 \\
\hline $\mathrm{C}$ & 2.386795 & -1.006771 & -0.348650 \\
\hline $\mathrm{C}$ & 2.834860 & -2.084920 & 0.412721 \\
\hline $\mathrm{C}$ & 4.011911 & -2.737763 & 0.081106 \\
\hline $\mathrm{C}$ & 3.124131 & -0.610097 & -1.464383 \\
\hline $\mathrm{C}$ & 4.305723 & -1.260391 & -1.786939 \\
\hline $\mathrm{C}$ & 4.756812 & -2.324895 & -1.016181 \\
\hline $\mathrm{H}$ & 2.264654 & -2.393683 & 1.283500 \\
\hline $\mathrm{H}$ & 4.352938 & -3.570763 & 0.689712 \\
\hline $\mathrm{H}$ & 4.875611 & -0.934584 & -2.652670 \\
\hline $\mathrm{H}$ & 5.682025 & -2.832397 & -1.272147 \\
\hline $\mathrm{H}$ & 2.769990 & 0.217815 & -2.072766 \\
\hline $\mathrm{C}$ & -0.474596 & -1.705412 & 2.650935 \\
\hline $\mathrm{C}$ & -2.117199 & -0.112547 & 2.482696 \\
\hline $\mathrm{C}$ & -0.604774 & -1.756581 & 4.026561 \\
\hline $\mathrm{C}$ & -2.317280 & -0.109722 & 3.849973 \\
\hline $\mathrm{C}$ & -1.544812 & -0.946012 & 4.641190 \\
\hline $\mathrm{H}$ & 0.238683 & -2.343353 & 2.141438 \\
\hline $\mathrm{H}$ & 0.024674 & -2.429714 & 4.597347 \\
\hline $\mathrm{H}$ & -1.674514 & -0.965535 & 5.718533 \\
\hline $\mathrm{H}$ & -3.067756 & 0.544633 & 4.278542 \\
\hline $\mathrm{H}$ & -2.702539 & 0.543116 & 1.845023 \\
\hline $\mathrm{C}$ & -3.783560 & -1.290972 & -0.002407 \\
\hline $\mathrm{C}$ & -5.157321 & -1.151262 & -0.031076 \\
\hline $\mathrm{C}$ & -5.699952 & 0.019145 & -0.537920 \\
\hline $\mathrm{C}$ & -4.844434 & 0.998295 & -1.018495 \\
\hline $\mathrm{C}$ & -3.481948 & 0.775661 & -0.969910 \\
\hline $\mathrm{H}$ & -3.327462 & -2.190021 & 0.401242 \\
\hline $\mathrm{H}$ & -5.784292 & -1.951830 & 0.344179 \\
\hline $\mathrm{H}$ & -6.775148 & 0.164623 & -0.564663 \\
\hline $\mathrm{H}$ & -2.790142 & 1.517342 & -1.355418 \\
\hline $\mathrm{H}$ & -5.220006 & 1.925133 & -1.436259 \\
\hline $\mathrm{C}$ & 1.048929 & 1.030574 & 0.126754 \\
\hline $\mathrm{N}$ & 1.890403 & 1.988657 & 0.252446 \\
\hline $\mathrm{N}$ & -0.316785 & 1.228358 & 0.044403 \\
\hline $\mathrm{Br}$ & -0.652497 & -3.143330 & -0.413367 \\
\hline $\mathrm{Br}$ & -0.727590 & -0.459113 & -2.796731 \\
\hline $\mathrm{C}$ & -0.872187 & 2.524584 & 0.031560 \\
\hline $\mathrm{C}$ & -1.509549 & 3.043609 & 1.156478 \\
\hline $\mathrm{C}$ & -0.841802 & 3.276864 & -1.143794 \\
\hline $\mathrm{C}$ & -2.141871 & 4.279362 & 1.094918 \\
\hline $\mathrm{H}$ & -1.501965 & 2.476497 & 2.082287 \\
\hline $\mathrm{C}$ & -1.468085 & 4.512853 & -1.197772 \\
\hline $\mathrm{H}$ & -0.336950 & 2.870042 & -2.016403 \\
\hline $\mathrm{C}$ & -2.131196 & 5.013653 & -0.082680 \\
\hline
\end{tabular}




$\begin{array}{lccc}\mathrm{H} & -2.642072 & 4.670385 & 1.976374 \\ \mathrm{H} & -1.443199 & 5.087347 & -2.118837 \\ \mathrm{H} & -2.629645 & 5.977388 & -0.130188 \\ \mathrm{C} & 3.251953 & 1.839392 & 0.489212 \\ \mathrm{C} & 4.151014 & 2.569760 & -0.297655 \\ \mathrm{C} & 3.765792 & 1.066523 & 1.538270 \\ \mathrm{C} & 5.516473 & 2.489244 & -0.077912 \\ \mathrm{H} & 3.750452 & 3.190139 & -1.095534 \\ \mathrm{C} & 5.132997 & 0.996785 & 1.758627 \\ \mathrm{H} & 3.080372 & 0.518156 & 2.180095 \\ \mathrm{C} & 6.018886 & 1.697754 & 0.949323 \\ \mathrm{H} & 6.195413 & 3.052916 & -0.712215 \\ \mathrm{H} & 5.510638 & 0.384550 & 2.573953 \\ \mathrm{H} & 7.088769 & 1.637186 & 1.124152\end{array}$

TS2-CM M06/6-311g(d,p)/superfine in PhCF3 Solvent Electronic energy -7390.875927 a.u.

Gibbs free energy -7390.512313 (-7390.508377) a.u.

\begin{tabular}{|c|c|c|c|}
\hline $\mathrm{Ti}$ & -0.972754 & -0.316278 & -0.293076 \\
\hline $\mathrm{N}$ & -3.056897 & 0.548932 & -0.396559 \\
\hline $\mathrm{N}$ & -1.415747 & -0.163557 & 1.944135 \\
\hline $\mathrm{N}$ & 0.907648 & -1.070866 & 0.048226 \\
\hline $\mathrm{C}$ & 1.652925 & -2.269470 & -0.153033 \\
\hline $\mathrm{C}$ & 1.497612 & -3.324591 & 0.738648 \\
\hline $\mathrm{C}$ & 2.230761 & -4.488479 & 0.561169 \\
\hline $\mathrm{C}$ & 2.532358 & -2.384670 & -1.225886 \\
\hline $\mathrm{C}$ & 3.261729 & -3.552795 & -1.395681 \\
\hline $\mathrm{C}$ & 3.115708 & -4.606525 & -0.503461 \\
\hline $\mathrm{H}$ & 0.806010 & -3.224764 & 1.568376 \\
\hline $\mathrm{H}$ & 2.108862 & -5.309299 & 1.261756 \\
\hline $\mathrm{H}$ & 3.945869 & -3.638071 & -2.234659 \\
\hline $\mathrm{H}$ & 3.687261 & -5.519622 & -0.639067 \\
\hline $\mathrm{H}$ & 2.638849 & -1.562665 & -1.928510 \\
\hline $\mathrm{C}$ & -1.252128 & -1.177936 & 2.802365 \\
\hline $\mathrm{C}$ & -1.743730 & 1.035901 & 2.447294 \\
\hline $\mathrm{C}$ & -1.397382 & -1.034482 & 4.171272 \\
\hline $\mathrm{C}$ & -1.923485 & 1.260308 & 3.798796 \\
\hline $\mathrm{C}$ & -1.742458 & 0.205827 & 4.681347 \\
\hline $\mathrm{H}$ & -1.015610 & -2.141298 & 2.361779 \\
\hline $\mathrm{H}$ & -1.246287 & -1.891141 & 4.818187 \\
\hline $\mathrm{H}$ & -1.869803 & 0.350153 & 5.749540 \\
\hline $\mathrm{H}$ & -2.196424 & 2.250287 & 4.146174 \\
\hline $\mathrm{H}$ & -1.862562 & 1.845510 & 1.733462 \\
\hline $\mathrm{C}$ & -4.133600 & -0.011328 & 0.171280 \\
\hline $\mathrm{C}$ & -5.386000 & 0.573781 & 0.136659 \\
\hline $\mathrm{C}$ & -5.540712 & 1.787802 & -0.513085 \\
\hline $\mathrm{C}$ & -4.432145 & 2.371731 & -1.106394 \\
\hline $\mathrm{C}$ & -3.214401 & 1.723435 & -1.025345 \\
\hline $\mathrm{H}$ & -3.972392 & -0.968010 & 0.659366 \\
\hline $\mathrm{H}$ & -6.222688 & 0.075985 & 0.613354 \\
\hline $\mathrm{H}$ & -6.511274 & 2.271470 & -0.558651 \\
\hline $\mathrm{H}$ & -2.327095 & 2.151603 & -1.480358 \\
\hline $\mathrm{H}$ & -4.501165 & 3.319058 & -1.628608 \\
\hline $\mathrm{C}$ & 1.492399 & 0.072076 & -0.086612 \\
\hline $\mathrm{N}$ & 2.433726 & 0.817454 & -0.219204 \\
\hline $\mathrm{C}$ & 3.777658 & 0.921704 & 0.115499 \\
\hline $\mathrm{C}$ & 4.440735 & -0.076047 & 0.835226 \\
\hline $\mathrm{C}$ & 4.467849 & 2.064936 & -0.286665 \\
\hline $\mathrm{C}$ & 5.783454 & 0.078726 & 1.142443 \\
\hline $\mathrm{H}$ & 3.898931 & -0.964753 & 1.148346 \\
\hline $\mathrm{C}$ & 5.810966 & 2.206392 & 0.023317 \\
\hline $\mathrm{H}$ & 3.932400 & 2.827461 & -0.845257 \\
\hline $\mathrm{C}$ & 6.473148 & 1.215850 & 0.738567 \\
\hline $\mathrm{H}$ & 6.295786 & -0.699068 & 1.700973 \\
\hline $\mathrm{H}$ & 6.344025 & 3.097338 & -0.294788 \\
\hline
\end{tabular}

$\begin{array}{lccc}\mathrm{H} & 7.525245 & 1.329202 & 0.981294 \\ \mathrm{~N} & -0.161919 & 1.238738 & -0.219953 \\ \mathrm{Br} & -0.945823 & -0.513328 & -2.797532 \\ \mathrm{Br} & -2.016004 & -2.713370 & -0.120183 \\ \mathrm{C} & 0.268165 & 2.544112 & -0.257091 \\ \mathrm{C} & 0.717563 & 3.197135 & 0.898930 \\ \mathrm{C} & 0.293284 & 3.233844 & -1.477321 \\ \mathrm{C} & 1.141288 & 4.515707 & 0.838633 \\ \mathrm{H} & 0.730449 & 2.651528 & 1.839133 \\ \mathrm{C} & 0.716319 & 4.552683 & -1.528234 \\ \mathrm{H} & -0.020791 & 2.708185 & -2.375559 \\ \mathrm{C} & 1.137436 & 5.200152 & -0.371581 \\ \mathrm{H} & 1.482897 & 5.012421 & 1.742361 \\ \mathrm{H} & 0.724951 & 5.078372 & -2.478901 \\ \mathrm{H} & 1.469500 & 6.233082 & -0.414878\end{array}$

IM3-CM M06/6-311g(d,p)/superfine in PhCF3 Solvent Electronic energy -6780.283090 a.u.

Gibbs free energy -6780.090640 (-6780.087435) a.u. 37

$\begin{array}{lrrr}\mathrm{Ti} & -0.129881 & -0.571340 & 0.008415 \\ \mathrm{~N} & -2.396784 & 0.212670 & 0.039306 \\ \mathrm{~N} & 1.549687 & -0.719425 & -0.134274 \\ \mathrm{C} & -2.794573 & 1.039624 & -0.936952 \\ \mathrm{C} & -4.113624 & 1.402953 & -1.131311 \\ \mathrm{C} & -5.078175 & 0.887853 & -0.277886 \\ \mathrm{C} & -4.679643 & 0.028385 & 0.732043 \\ \mathrm{C} & -3.335610 & -0.282186 & 0.853362 \\ \mathrm{H} & -2.021895 & 1.424608 & -1.598753 \\ \mathrm{H} & -4.373955 & 2.075881 & -1.940419 \\ \mathrm{H} & -6.123915 & 1.151158 & -0.401449 \\ \mathrm{H} & -2.987693 & -0.954033 & 1.633246 \\ \mathrm{H} & -5.394944 & -0.403661 & 1.422857 \\ \mathrm{Br} & -0.924773 & -1.959198 & -1.870537 \\ \mathrm{Br} & -0.400006 & -1.411454 & 2.301502 \\ \mathrm{~N} & 0.140888 & 1.579147 & -0.087233 \\ \mathrm{C} & 0.784067 & 2.111311 & -1.136986 \\ \mathrm{C} & -0.223427 & 2.379794 & 0.923438 \\ \mathrm{C} & 1.066257 & 3.460567 & -1.220769 \\ \mathrm{H} & 1.078810 & 1.422506 & -1.924965 \\ \mathrm{C} & 0.047820 & 3.734867 & 0.924579 \\ \mathrm{H} & -0.749370 & 1.912525 & 1.751679 \\ \mathrm{C} & 0.697392 & 4.286341 & -0.168997 \\ \mathrm{H} & 1.577389 & 3.848929 & -2.093796 \\ \mathrm{H} & -0.255321 & 4.342046 & 1.769461 \\ \mathrm{H} & 0.916887 & 5.348555 & -0.200493 \\ \mathrm{C} & 2.899377 & -0.518809 & -0.115945 \\ \mathrm{C} & 3.493920 & 0.195566 & 0.939746 \\ \mathrm{C} & 3.723406 & -0.995138 & -1.149881 \\ \mathrm{C} & 4.860808 & 0.417701 & 0.957489 \\ \mathrm{H} & 2.853609 & 0.560214 & 1.740179 \\ \mathrm{C} & 5.089502 & -0.767907 & -1.120128 \\ \mathrm{H} & 3.264825 & -1.547166 & -1.966249 \\ \mathrm{C} & 5.667190 & -0.061483 & -0.069942 \\ \mathrm{H} & 5.304023 & 0.969715 & 1.782110 \\ \mathrm{H} & 5.712854 & -1.145783 & -1.926231 \\ \mathrm{H} & 6.738687 & 0.113412 & -0.051857\end{array}$


Pathway 3 (Purple)

Same start in SI Part I where L=pyridine/pyridine for IM0 geometry

TS1-CM M06/6-311g(d,p)/superfine in PhCF3 Solvent Electronic energy -7243.357929 a.u.

Gibbs free energy -7242.930819 (-7242.928339) a.u. 66

\begin{tabular}{|c|c|c|c|}
\hline $\mathrm{Ti}$ & -0.556472 & -0.468521 & -0.030455 \\
\hline N & -2.978344 & -0.190873 & -0.150389 \\
\hline $\mathrm{N}$ & -0.708296 & 1.150746 & 1.570042 \\
\hline N & 1.187224 & -0.606509 & 0.149039 \\
\hline $\mathrm{C}$ & 2.310133 & -1.404290 & 0.256857 \\
\hline $\mathrm{C}$ & 2.826813 & -1.733411 & 1.515699 \\
\hline $\mathrm{C}$ & 3.925132 & -2.572651 & 1.625864 \\
\hline $\mathrm{C}$ & 2.919245 & -1.939727 & -0.885430 \\
\hline $\mathrm{C}$ & 4.016158 & -2.777273 & -0.765723 \\
\hline $\mathrm{C}$ & 4.527893 & -3.095588 & 0.487630 \\
\hline $\mathrm{H}$ & 2.346603 & -1.329402 & 2.402618 \\
\hline $\mathrm{H}$ & 4.312214 & -2.822765 & 2.609879 \\
\hline $\mathrm{H}$ & 4.475240 & -3.189247 & -1.660308 \\
\hline $\mathrm{H}$ & 5.387255 & -3.753493 & 0.576769 \\
\hline $\mathrm{H}$ & 2.507698 & -1.697835 & -1.861180 \\
\hline $\mathrm{C}$ & -0.051247 & 0.998786 & 2.728579 \\
\hline C & -1.310441 & 2.324062 & 1.340268 \\
\hline $\mathrm{C}$ & 0.027829 & 1.999037 & 3.680296 \\
\hline $\mathrm{C}$ & -1.280835 & 3.375735 & 2.237900 \\
\hline $\mathrm{C}$ & -0.596085 & 3.211789 & 3.431884 \\
\hline $\mathrm{H}$ & 0.416226 & 0.032829 & 2.890114 \\
\hline $\mathrm{H}$ & 0.573478 & 1.820770 & 4.599927 \\
\hline $\mathrm{H}$ & -0.550891 & 4.016604 & 4.158730 \\
\hline $\mathrm{H}$ & -1.788778 & 4.302614 & 1.996139 \\
\hline $\mathrm{H}$ & -1.839575 & 2.418725 & 0.397018 \\
\hline $\mathrm{C}$ & -3.663529 & 0.143674 & 0.952121 \\
\hline $\mathrm{C}$ & -5.040738 & 0.263766 & 0.985407 \\
\hline $\mathrm{C}$ & -5.760364 & 0.016783 & -0.173527 \\
\hline $\mathrm{C}$ & -5.067222 & -0.348387 & -1.315376 \\
\hline $\mathrm{C}$ & -3.687097 & -0.441891 & -1.257682 \\
\hline $\mathrm{H}$ & -3.082184 & 0.308467 & 1.853925 \\
\hline $\mathrm{H}$ & -5.533982 & 0.538817 & 1.911002 \\
\hline $\mathrm{H}$ & -6.842762 & 0.098655 & -0.182751 \\
\hline $\mathrm{H}$ & -3.118329 & -0.748924 & -2.129904 \\
\hline $\mathrm{H}$ & -5.581151 & -0.566667 & -2.244893 \\
\hline $\mathrm{C}$ & 1.334877 & 0.933469 & -0.928226 \\
\hline $\mathrm{N}$ & 2.447072 & 1.420321 & -1.088794 \\
\hline $\mathrm{C}$ & 3.575397 & 1.883782 & -0.286012 \\
\hline $\mathrm{N}$ & 0.088131 & 1.038247 & -1.298397 \\
\hline $\mathrm{C}$ & -0.281954 & 2.086118 & -2.292238 \\
\hline $\mathrm{C}$ & 0.051290 & 3.483867 & -1.783415 \\
\hline $\mathrm{H}$ & 1.121951 & 3.593553 & -1.589657 \\
\hline $\mathrm{H}$ & -0.231959 & 4.225270 & -2.539781 \\
\hline $\mathrm{H}$ & -0.494768 & 3.717685 & -0.863247 \\
\hline $\mathrm{C}$ & -1.773364 & 1.978155 & -2.554155 \\
\hline $\mathrm{H}$ & -2.023929 & 0.991130 & -2.955816 \\
\hline $\mathrm{H}$ & -2.363913 & 2.145311 & -1.646395 \\
\hline $\mathrm{H}$ & -2.072012 & 2.730520 & -3.292320 \\
\hline $\mathrm{C}$ & 0.464951 & 1.809525 & -3.593477 \\
\hline $\mathrm{H}$ & 0.137623 & 2.513336 & -4.367400 \\
\hline $\mathrm{H}$ & 1.545983 & 1.920529 & -3.466115 \\
\hline $\mathrm{H}$ & 0.257726 & 0.791413 & -3.942252 \\
\hline $\mathrm{Br}$ & -0.799917 & -2.122666 & -1.916087 \\
\hline $\mathrm{Br}$ & -1.152087 & -2.136952 & 1.787976 \\
\hline $\mathrm{C}$ & 4.754889 & 0.924101 & -0.382230 \\
\hline $\mathrm{H}$ & 5.636366 & 1.378682 & 0.084547 \\
\hline $\mathrm{H}$ & 4.547827 & -0.021701 & 0.123455 \\
\hline 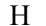 & & & \\
\hline
\end{tabular}

$\begin{array}{llll}\mathrm{C} & 3.994249 & 3.231274 & -0.870059 \\ \mathrm{H} & 4.262791 & 3.123665 & -1.927056 \\ \mathrm{H} & 3.183283 & 3.963579 & -0.792939 \\ \mathrm{H} & 4.862914 & 3.624982 & -0.330028 \\ \mathrm{C} & 3.143556 & 2.067811 & 1.163711 \\ \mathrm{H} & 2.313133 & 2.783304 & 1.227524 \\ \mathrm{H} & 2.820885 & 1.118335 & 1.603826 \\ \mathrm{H} & 3.977416 & 2.458389 & 1.758823\end{array}$

IM2-CM M06/6-311g(d,p)/superfine in PhCF3 Solvent Electronic energy -7243.380566 a.u.

Gibbs free energy -7242.948226 (-7242.945919) a.u. 66

\begin{tabular}{|c|c|c|c|}
\hline Гi & -0.645264 & -0.294719 & -0.191189 \\
\hline $\mathrm{N}$ & -2.998466 & -0.265341 & -0.265164 \\
\hline $\mathrm{N}$ & -1.048011 & 1.006787 & 1.625422 \\
\hline $\mathrm{N}$ & 1.280489 & -0.310036 & 0.161340 \\
\hline $\mathrm{C}$ & 2.240658 & -1.324886 & 0.316885 \\
\hline $\mathrm{C}$ & 2.466699 & -1.915366 & 1.560754 \\
\hline $\mathrm{C}$ & 3.402648 & -2.927711 & 1.700388 \\
\hline $\mathrm{C}$ & 2.952497 & -1.793869 & -0.787995 \\
\hline $\mathrm{C}$ & 3.896091 & -2.801382 & -0.643468 \\
\hline $\mathrm{C}$ & 4.129344 & -3.371282 & 0.601133 \\
\hline $\mathrm{H}$ & 1.914390 & -1.558702 & 2.424262 \\
\hline $\mathrm{H}$ & 3.571573 & -3.370047 & 2.678317 \\
\hline $\mathrm{H}$ & 4.444919 & -3.149237 & -1.514495 \\
\hline $\mathrm{H}$ & 4.864948 & -4.162321 & 0.713034 \\
\hline $\mathrm{H}$ & 2.756560 & -1.363037 & -1.766226 \\
\hline $\mathrm{C}$ & -0.372993 & 0.797939 & 2.764647 \\
\hline $\mathrm{C}$ & -1.824981 & 2.096369 & 1.547899 \\
\hline $\mathrm{C}$ & -0.443815 & 1.658983 & 3.845000 \\
\hline $\mathrm{C}$ & -1.958314 & 3.000907 & 2.583724 \\
\hline $\mathrm{C}$ & -1.250870 & 2.781319 & 3.755966 \\
\hline $\mathrm{H}$ & 0.238623 & -0.096826 & 2.804001 \\
\hline $\mathrm{H}$ & 0.127692 & 1.440914 & 4.739985 \\
\hline $\mathrm{H}$ & -1.328406 & 3.474789 & 4.587111 \\
\hline $\mathrm{H}$ & -2.605391 & 3.862292 & 2.463681 \\
\hline $\mathrm{H}$ & -2.365235 & 2.244915 & 0.617354 \\
\hline $\mathrm{C}$ & -3.710092 & -0.399074 & 0.865211 \\
\hline C & -5.091018 & -0.398398 & 0.894799 \\
\hline $\mathrm{C}$ & -5.786343 & -0.255338 & -0.295880 \\
\hline C & -5.065059 & -0.127106 & -1.470798 \\
\hline $\mathrm{C}$ & -3.683398 & -0.142839 & -1.411236 \\
\hline $\mathrm{H}$ & -3.144031 & -0.525069 & 1.781813 \\
\hline $\mathrm{H}$ & -5.605710 & -0.514521 & 1.841669 \\
\hline $\mathrm{H}$ & -6.871482 & -0.251801 & -0.307444 \\
\hline $\mathrm{H}$ & -3.096772 & -0.070800 & -2.320093 \\
\hline $\mathrm{H}$ & -5.557261 & -0.022931 & -2.430818 \\
\hline $\mathrm{C}$ & 1.510583 & 0.920568 & -0.494241 \\
\hline N & 2.502872 & 1.697804 & -0.635171 \\
\hline $\mathrm{C}$ & 3.857947 & 1.734992 & -0.102622 \\
\hline $\mathrm{N}$ & 0.233641 & 1.230960 & -0.985930 \\
\hline C & -0.039709 & 2.398040 & -1.842078 \\
\hline C & 0.155007 & 3.706451 & -1.077762 \\
\hline $\mathrm{H}$ & 1.188168 & 3.813231 & -0.740644 \\
\hline $\mathrm{H}$ & -0.091634 & 4.554130 & -1.729227 \\
\hline 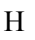 & -0.503957 & 3.751512 & -0.202627 \\
\hline C & -1.488467 & 2.303027 & -2.301842 \\
\hline $\mathrm{H}$ & -1.637132 & 1.415847 & -2.926961 \\
\hline $\mathrm{H}$ & -2.180645 & 2.257176 & -1.453300 \\
\hline $\mathrm{H}$ & -1.750732 & 3.183534 & -2.898410 \\
\hline & 0.844083 & 2.373312 & -3.089809 \\
\hline $\mathrm{H}$ & 0.512193 & 3.151988 & -3.787477 \\
\hline & 1.892956 & 2.546158 & -2.841076 \\
\hline & 0.759625 & 1.403954 & -3.595767 \\
\hline & -0.909475 & -2.326796 & 1.300546 \\
\hline
\end{tabular}




$\begin{array}{lccc}\mathrm{Br} & -0.758071 & -1.623165 & -2.293343 \\ \mathrm{C} & 4.088099 & 1.039456 & 1.239100 \\ \mathrm{H} & 3.281150 & 1.268480 & 1.947453 \\ \mathrm{H} & 4.166085 & -0.044432 & 1.140903 \\ \mathrm{H} & 5.027123 & 1.398080 & 1.677938 \\ \mathrm{C} & 4.825008 & 1.187506 & -1.149799 \\ \mathrm{H} & 4.703374 & 1.723608 & -2.099284 \\ \mathrm{H} & 5.860686 & 1.316377 & -0.813042 \\ \mathrm{H} & 4.656511 & 0.120887 & -1.330977 \\ \mathrm{C} & 4.155952 & 3.225984 & 0.088583 \\ \mathrm{H} & 5.194195 & 3.381647 & 0.405991 \\ \mathrm{H} & 3.991191 & 3.772258 & -0.847943 \\ \mathrm{H} & 3.495350 & 3.653608 & 0.853515\end{array}$

TS2-CM M06/6-311g(d,p)/superfine in PhCF3 Solvent Electronic energy -7243.347324 a.u.

Gibbs free energy -7242.922960 (-7242.919075) a.u.

$\begin{array}{lrrr}66 & & & \\ \mathrm{Ti} & -0.682185 & -0.047126 & -0.322502 \\ \mathrm{~N} & -2.965188 & 0.079705 & -0.176881 \\ \mathrm{~N} & -0.815051 & -0.593557 & 1.906632 \\ \mathrm{~N} & 1.285628 & -0.401646 & -0.168118 \\ \mathrm{C} & 2.265203 & -1.420159 & -0.309543 \\ \mathrm{C} & 3.025507 & -1.820559 & 0.784652 \\ \mathrm{C} & 3.994576 & -2.803024 & 0.628641 \\ \mathrm{C} & 2.454637 & -2.016625 & -1.550987 \\ \mathrm{C} & 3.424895 & -2.996469 & -1.699542 \\ \mathrm{C} & 4.199654 & -3.388955 & -0.613749 \\ \mathrm{H} & 2.854715 & -1.355341 & 1.752501 \\ \mathrm{H} & 4.589630 & -3.112355 & 1.483053 \\ \mathrm{H} & 3.576609 & -3.458370 & -2.670759 \\ \mathrm{H} & 4.957827 & -4.156841 & -0.735161 \\ \mathrm{H} & 1.835169 & -1.700666 & -2.385223 \\ \mathrm{C} & -0.262997 & -1.712819 & 2.392971 \\ \mathrm{C} & -1.298501 & 0.297527 & 2.783232 \\ \mathrm{C} & -0.169191 & -1.975289 & 3.749087 \\ \mathrm{C} & -1.259889 & 0.105887 & 4.151728 \\ \mathrm{C} & -0.679147 & -1.052015 & 4.647045 \\ \mathrm{H} & 0.100410 & -2.422623 & 1.655619 \\ \mathrm{H} & 0.294037 & -2.896260 & 4.084939 \\ \mathrm{H} & -0.626005 & -1.231148 & 5.716311 \\ \mathrm{H} & -1.675488 & 0.858911 & 4.811836 \\ \mathrm{H} & -1.734493 & 1.198224 & 2.362633 \\ \mathrm{C} & -3.674765 & -0.675029 & 0.674801 \\ \mathrm{C} & -5.053239 & -0.621619 & 0.759619 \\ \mathrm{C} & -5.743122 & 0.239510 & -0.079557 \\ \mathrm{C} & -5.021574 & 1.008953 & -0.977106 \\ \mathrm{C} & -3.642904 & 0.897992 & -0.993704 \\ \mathrm{H} & -3.111832 & -1.359160 & 1.300323 \\ \mathrm{H} & -5.570456 & -1.255900 & 1.470541 \\ \mathrm{H} & -6.826052 & 0.302150 & -0.040462 \\ \mathrm{H} & -3.049422 & 1.468130 & -1.700957 \\ \mathrm{H} & -1.881618 & 4.510614 & 0.517879 \\ \mathrm{H} & -5.511989 & 1.687594 & -1.665688 \\ \mathrm{C} & 1.630891 & 0.838212 & 0.027025 \\ \mathrm{~N} & 2.424406 & 1.731457 & 0.151811 \\ \mathrm{C} & 3.869476 & 1.988141 & 0.197299 \\ \mathrm{~N} & -0.265315 & 1.595550 & 0.088524 \\ \mathrm{C} & -0.318969 & 3.038969 & 0.278132 \\ \mathrm{C} & 0.318609 & 3.473030 & 1.600311 \\ \mathrm{H} & 1.374630 & 3.203931 & 1.655526 \\ \mathrm{H} & 0.235253 & 4.561683 & 1.707874 \\ \mathrm{H} & -0.200668 & 3.011811 & 2.448534 \\ \mathrm{H} & -1.796383 & 3.435389 & 0.318043 \\ \mathrm{H} & -282350 & 3.231568 & -0.640908 \\ \mathrm{H} & & & \\ \mathrm{H} & & & \\ \mathrm{H} & & & \\ \mathrm{H} & & & \\ \mathrm{H} & & & \end{array}$

$\begin{array}{lccc}\mathrm{C} & 0.317727 & 3.757296 & -0.913191 \\ \mathrm{H} & 0.155468 & 4.838921 & -0.825065 \\ \mathrm{H} & 1.390839 & 3.572022 & -0.976582 \\ \mathrm{H} & -0.145361 & 3.409722 & -1.843548 \\ \mathrm{Br} & -0.760312 & 0.356905 & -2.833870 \\ \mathrm{Br} & -1.154601 & -2.638314 & -0.741297 \\ \mathrm{C} & 4.577921 & 1.153643 & -0.861070 \\ \mathrm{H} & 4.504880 & 0.083493 & -0.641857 \\ \mathrm{H} & 4.146482 & 1.337796 & -1.851431 \\ \mathrm{H} & 5.639279 & 1.425981 & -0.893042 \\ \mathrm{C} & 4.373121 & 1.639612 & 1.590520 \\ \mathrm{H} & 4.225359 & 0.576613 & 1.807444 \\ \mathrm{H} & 5.444664 & 1.858479 & 1.661216 \\ \mathrm{H} & 3.850825 & 2.229223 & 2.352003 \\ \mathrm{C} & 4.087208 & 3.468478 & -0.078651 \\ \mathrm{H} & 3.743906 & 3.733114 & -1.084667 \\ \mathrm{H} & 3.547234 & 4.086952 & 0.646649 \\ \mathrm{H} & 5.154065 & 3.706882 & -0.008223\end{array}$

IM3-CM M06/6-311g(d,p)/superfine in PhCF3 Solvent Same IM3-CM as SI part II Carbodiimide Metathesis 
Pathway 4 (Gray)

Same start in SI Part I where L=pyridine/pyridine for IM0 geometry

TS1-CM M06/6-311g(d,p)/superfine in PhCF3 Solvent Electronic energy -7317.119375 a.u.

Gibbs free energy $-7316.725536(-7316.721958)$ a.u. 64

\begin{tabular}{|c|c|c|c|}
\hline $\mathrm{Ti}$ & -0.255547 & -0.874618 & -0.101576 \\
\hline $\mathrm{N}$ & -2.644617 & -1.000626 & -0.032933 \\
\hline $\mathrm{N}$ & -0.603204 & 0.188824 & 1.889020 \\
\hline $\mathrm{N}$ & 1.469218 & -0.543265 & -0.128089 \\
\hline $\mathrm{C}$ & 2.775620 & -0.910621 & -0.376719 \\
\hline $\mathrm{C}$ & 3.563390 & -1.453279 & 0.646606 \\
\hline $\mathrm{C}$ & 4.861764 & -1.865701 & 0.389496 \\
\hline $\mathrm{C}$ & 3.323140 & -0.794746 & -1.661502 \\
\hline $\mathrm{C}$ & 4.620994 & -1.211619 & -1.909174 \\
\hline $\mathrm{C}$ & 5.398824 & -1.744700 & -0.887163 \\
\hline $\mathrm{H}$ & 3.133655 & -1.556421 & 1.639455 \\
\hline $\mathrm{H}$ & 5.458720 & -2.289111 & 1.192627 \\
\hline $\mathrm{H}$ & 5.029535 & -1.121319 & -2.911999 \\
\hline $\mathrm{H}$ & 6.415574 & -2.070024 & -1.086091 \\
\hline $\mathrm{H}$ & 2.708940 & -0.386958 & -2.459311 \\
\hline $\mathrm{C}$ & 0.228686 & -0.059094 & 2.911342 \\
\hline $\mathrm{C}$ & -1.524165 & 1.148448 & 2.049806 \\
\hline $\mathrm{C}$ & 0.169566 & 0.628085 & 4.109560 \\
\hline $\mathrm{C}$ & -1.648454 & 1.885079 & 3.214195 \\
\hline $\mathrm{C}$ & -0.785725 & 1.620631 & 4.266100 \\
\hline $\mathrm{H}$ & 0.960969 & -0.844275 & 2.753774 \\
\hline $\mathrm{H}$ & 0.867344 & 0.383242 & 4.902190 \\
\hline $\mathrm{H}$ & -0.857054 & 2.178667 & 5.194221 \\
\hline $\mathrm{H}$ & -2.413625 & 2.650059 & 3.284536 \\
\hline $\mathrm{H}$ & -2.188582 & 1.335554 & 1.211416 \\
\hline $\mathrm{C}$ & -3.283308 & -1.338384 & 1.096518 \\
\hline $\mathrm{C}$ & -4.660844 & -1.395822 & 1.198525 \\
\hline $\mathrm{C}$ & -5.426650 & -1.090557 & 0.083567 \\
\hline $\mathrm{C}$ & -4.778648 & -0.754552 & -1.093496 \\
\hline $\mathrm{C}$ & -3.394749 & -0.730955 & -1.107873 \\
\hline $\mathrm{H}$ & -2.658145 & -1.581377 & 1.950816 \\
\hline $\mathrm{H}$ & -5.118631 & -1.679168 & 2.139620 \\
\hline $\mathrm{H}$ & -6.510643 & -1.123520 & 0.130052 \\
\hline $\mathrm{H}$ & -2.857665 & -0.507448 & -2.023447 \\
\hline $\mathrm{H}$ & -5.329353 & -0.520331 & -1.997632 \\
\hline $\mathrm{C}$ & 1.021422 & 1.276244 & -0.597873 \\
\hline $\mathrm{N}$ & 1.909260 & 2.102264 & -0.597729 \\
\hline $\mathrm{C}$ & 2.981430 & 2.645040 & 0.229488 \\
\hline $\mathrm{N}$ & -0.240784 & 1.073081 & -0.867857 \\
\hline $\mathrm{Br}$ & -0.413663 & -1.957049 & -2.355609 \\
\hline $\mathrm{Br}$ & -0.230259 & -3.026463 & 1.202250 \\
\hline $\mathrm{C}$ & 4.340705 & 2.248114 & -0.329222 \\
\hline $\mathrm{H}$ & 4.519401 & 1.175299 & -0.220858 \\
\hline $\mathrm{H}$ & 4.410046 & 2.506302 & -1.391766 \\
\hline $\mathrm{H}$ & 5.128832 & 2.787146 & 0.208584 \\
\hline $\mathrm{C}$ & 2.837668 & 4.162975 & 0.174814 \\
\hline $\mathrm{H}$ & 2.924457 & 4.519723 & -0.857047 \\
\hline $\mathrm{H}$ & 1.864689 & 4.478285 & 0.567099 \\
\hline $\mathrm{H}$ & 3.622326 & 4.637620 & 0.774550 \\
\hline $\mathrm{C}$ & 2.821787 & 2.160421 & 1.664359 \\
\hline $\mathrm{H}$ & 1.843356 & 2.456170 & 2.064460 \\
\hline $\mathrm{H}$ & 2.910144 & 1.070784 & 1.724268 \\
\hline $\mathrm{H}$ & 3.598874 & 2.604903 & 2.296864 \\
\hline $\mathrm{C}$ & -1.059805 & 2.185945 & -1.183499 \\
\hline $\mathrm{C}$ & -1.050551 & 3.352061 & -0.417351 \\
\hline $\mathrm{C}$ & -1.901631 & 2.100539 & -2.289437 \\
\hline $\mathrm{C}$ & -1.888579 & 4.407014 & -0.747518 \\
\hline $\mathrm{H}$ & & 3.424809 & 0.11 \\
\hline
\end{tabular}

$\begin{array}{llll}\mathrm{C} & -2.739142 & 3.158440 & -2.613639 \\ \mathrm{H} & -1.866900 & 1.207651 & -2.906526 \\ \mathrm{C} & -2.739343 & 4.313232 & -1.842196 \\ \mathrm{H} & -1.876746 & 5.309436 & -0.143095 \\ \mathrm{H} & -3.387199 & 3.082622 & -3.481866 \\ \mathrm{H} & -3.394280 & 5.140805 & -2.097069\end{array}$

IM2-CM M06/6-311g(d,p)/superfine in PhCF3 Solvent Electronic energy -7317.148520 a.u. Gibbs free energy -7316.749476 (-7316.746018) a.u. 64

\begin{tabular}{|c|c|c|c|}
\hline $\mathrm{Ti}$ & -0.327753 & -0.840622 & -0.033807 \\
\hline $\mathrm{N}$ & -2.560676 & -1.111810 & -0.386277 \\
\hline $\mathrm{N}$ & -1.028370 & 0.325863 & 1.793313 \\
\hline $\mathrm{N}$ & 1.490638 & -0.157939 & 0.025031 \\
\hline $\mathrm{C}$ & 2.736799 & -0.787296 & -0.118788 \\
\hline $\mathrm{C}$ & 3.269910 & -1.523875 & 0.938992 \\
\hline $\mathrm{C}$ & 4.500131 & -2.148955 & 0.808440 \\
\hline $\mathrm{C}$ & 3.440471 & -0.723811 & -1.323199 \\
\hline $\mathrm{C}$ & 4.673187 & -1.346902 & -1.446517 \\
\hline $\mathrm{C}$ & 5.212989 & -2.057115 & -0.381252 \\
\hline $\mathrm{H}$ & 2.713835 & -1.587526 & 1.869645 \\
\hline $\mathrm{H}$ & 4.907748 & -2.709309 & 1.645104 \\
\hline $\mathrm{H}$ & 5.212470 & -1.282567 & -2.387598 \\
\hline $\mathrm{H}$ & 6.178057 & -2.544694 & -0.481002 \\
\hline $\mathrm{H}$ & 3.015401 & -0.180692 & -2.162102 \\
\hline $\mathrm{C}$ & -0.156992 & 0.475107 & 2.804559 \\
\hline $\mathrm{C}$ & -2.173257 & 1.020028 & 1.851222 \\
\hline $\mathrm{C}$ & -0.392047 & 1.308526 & 3.881178 \\
\hline $\mathrm{C}$ & -2.497064 & 1.853405 & 2.907512 \\
\hline $\mathrm{C}$ & -1.589153 & 2.006738 & 3.940962 \\
\hline $\mathrm{H}$ & 0.763045 & -0.096399 & 2.739485 \\
\hline $\mathrm{H}$ & 0.354502 & 1.394630 & 4.662437 \\
\hline $\mathrm{H}$ & -1.807839 & 2.660339 & 4.779221 \\
\hline $\mathrm{H}$ & -3.444082 & 2.380985 & 2.899110 \\
\hline $\mathrm{H}$ & -2.857754 & 0.915052 & 1.015345 \\
\hline $\mathrm{C}$ & -3.340687 & -1.656553 & 0.561959 \\
\hline $\mathrm{C}$ & -4.692639 & -1.877966 & 0.384180 \\
\hline $\mathrm{C}$ & -5.276786 & -1.518829 & -0.820367 \\
\hline $\mathrm{C}$ & -4.478174 & -0.966369 & -1.809194 \\
\hline $\mathrm{C}$ & -3.130943 & -0.792091 & -1.557191 \\
\hline $\mathrm{H}$ & -2.854776 & -1.922362 & 1.495630 \\
\hline $\mathrm{H}$ & -5.270862 & -2.325698 & 1.184086 \\
\hline $\mathrm{H}$ & -6.337404 & -1.675163 & -0.989173 \\
\hline $\mathrm{H}$ & -2.474658 & -0.393690 & -2.321804 \\
\hline $\mathrm{H}$ & -4.884089 & -0.679993 & -2.772476 \\
\hline $\mathrm{C}$ & 1.168775 & 1.117090 & -0.490116 \\
\hline $\mathrm{N}$ & 1.776967 & 2.219429 & -0.616456 \\
\hline $\mathrm{C}$ & 3.064046 & 2.719060 & -0.148475 \\
\hline $\mathrm{N}$ & -0.190907 & 0.973387 & -0.813718 \\
\hline $\mathrm{Br}$ & -0.112462 & -2.739377 & 1.569465 \\
\hline $\mathrm{Br}$ & -0.021720 & -2.246686 & -2.039964 \\
\hline $\mathrm{C}$ & -0.978383 & 2.111772 & -1.057450 \\
\hline $\mathrm{C}$ & -1.081210 & 3.155265 & -0.130822 \\
\hline $\mathrm{C}$ & -1.697486 & 2.203681 & -2.248830 \\
\hline $\mathrm{C}$ & -1.907573 & 4.239049 & -0.382055 \\
\hline $\mathrm{H}$ & -0.510400 & 3.107428 & 0.791895 \\
\hline $\mathrm{C}$ & -2.523356 & 3.291819 & -2.498997 \\
\hline $\mathrm{H}$ & -1.574043 & 1.422299 & -2.993416 \\
\hline $\mathrm{C}$ & -2.637467 & 4.310976 & -1.564022 \\
\hline $\mathrm{H}$ & -1.980987 & 5.037215 & 0.351696 \\
\hline $\mathrm{H}$ & -3.071715 & 3.345666 & -3.435183 \\
\hline $\mathrm{H}$ & -3.282987 & 5.162508 & -1.757515 \\
\hline $\mathrm{C}$ & 4.014455 & 2.816112 & -1.338559 \\
\hline $\mathrm{H}$ & 3.556630 & 3.400118 & -2.144838 \\
\hline . & 4.948050 & 3.309159 & -1.041581 \\
\hline
\end{tabular}




$\begin{array}{llll}\mathrm{H} & 4.263637 & 1.824121 & -1.729440 \\ \mathrm{C} & 3.732159 & 1.954137 & 0.993079 \\ \mathrm{H} & 3.017736 & 1.735153 & 1.796869 \\ \mathrm{H} & 4.184880 & 1.016580 & 0.664961 \\ \mathrm{H} & 4.531108 & 2.572241 & 1.420337 \\ \mathrm{C} & 2.764582 & 4.135228 & 0.352801 \\ \mathrm{H} & 3.687924 & 4.657362 & 0.631212 \\ \mathrm{H} & 2.250998 & 4.714046 & -0.422669 \\ \mathrm{H} & 2.113202 & 4.097204 & 1.235399\end{array}$

TS2-CM M06/6-311g(d,p)/superfine in PhCF3 Solvent Electronic energy -7317.121841 a.u.

Gibbs free energy $-7316.728790(-7316.725154)$ a.u.

64

\begin{tabular}{|c|c|c|c|}
\hline $\mathrm{Ti}$ & -0.676063 & -0.434537 & -0.432017 \\
\hline $\mathrm{N}$ & -2.896840 & -0.231333 & -0.069147 \\
\hline $\mathrm{N}$ & -0.750188 & -0.818814 & 1.825120 \\
\hline $\mathrm{N}$ & 1.334116 & -0.606328 & -0.313270 \\
\hline $\mathrm{C}$ & 2.393322 & -1.547233 & -0.253791 \\
\hline $\mathrm{C}$ & 3.168811 & -1.673886 & 0.896451 \\
\hline $\mathrm{C}$ & 4.216007 & -2.584433 & 0.927181 \\
\hline $\mathrm{C}$ & 2.654289 & -2.346010 & -1.361834 \\
\hline $\mathrm{C}$ & 3.704391 & -3.251515 & -1.324721 \\
\hline $\mathrm{C}$ & 4.490504 & -3.370868 & -0.184630 \\
\hline $\mathrm{H}$ & 2.948937 & -1.053585 & 1.762196 \\
\hline $\mathrm{H}$ & 4.819521 & -2.679305 & 1.825310 \\
\hline $\mathrm{H}$ & 3.911078 & -3.868153 & -2.194587 \\
\hline $\mathrm{H}$ & 5.312042 & -4.080500 & -0.160983 \\
\hline $\mathrm{H}$ & 2.029767 & -2.241794 & -2.243975 \\
\hline $\mathrm{C}$ & -0.133231 & -1.856922 & 2.402963 \\
\hline $\mathrm{C}$ & -1.303604 & 0.106017 & 2.622825 \\
\hline $\mathrm{C}$ & -0.042750 & -2.006022 & 3.776447 \\
\hline $\mathrm{C}$ & -1.270454 & 0.025180 & 4.002163 \\
\hline $\mathrm{C}$ & -0.624271 & -1.050593 & 4.593088 \\
\hline $\mathrm{H}$ & 0.291214 & -2.595412 & 1.729558 \\
\hline $\mathrm{H}$ & 0.474109 & -2.865505 & 4.188226 \\
\hline $\mathrm{H}$ & -0.575520 & -1.141378 & 5.673583 \\
\hline $\mathrm{H}$ & -1.742013 & 0.799591 & 4.596487 \\
\hline $\mathrm{H}$ & -1.787772 & 0.944270 & 2.130045 \\
\hline $\mathrm{C}$ & -3.658750 & -1.192870 & 0.469640 \\
\hline $\mathrm{C}$ & -5.008243 & -1.024199 & 0.719142 \\
\hline $\mathrm{C}$ & -5.602497 & 0.186145 & 0.399397 \\
\hline $\mathrm{C}$ & -4.821295 & 1.184261 & -0.162152 \\
\hline $\mathrm{C}$ & -3.479112 & 0.936209 & -0.379743 \\
\hline $\mathrm{H}$ & -3.156416 & -2.129094 & 0.695138 \\
\hline $\mathrm{H}$ & -5.577497 & -1.836361 & 1.156705 \\
\hline $\mathrm{H}$ & -6.659817 & 0.349061 & 0.582939 \\
\hline $\mathrm{H}$ & -2.839748 & 1.695105 & -0.819770 \\
\hline $\mathrm{H}$ & -5.239104 & 2.147320 & -0.432213 \\
\hline $\mathrm{C}$ & 1.567754 & 0.658182 & -0.070835 \\
\hline $\mathrm{N}$ & 2.275999 & 1.599516 & 0.149052 \\
\hline $\mathrm{C}$ & 3.626721 & 2.143743 & 0.042120 \\
\hline $\mathrm{N}$ & -0.297627 & 1.263729 & -0.126469 \\
\hline $\mathrm{Br}$ & -1.074176 & -0.170725 & -2.900988 \\
\hline $\mathrm{Br}$ & -0.947452 & -3.028974 & -0.670303 \\
\hline $\mathrm{C}$ & 4.481441 & 1.269839 & -0.865708 \\
\hline $\mathrm{H}$ & 4.608417 & 0.264678 & -0.449255 \\
\hline $\mathrm{H}$ & 4.027313 & 1.180291 & -1.859094 \\
\hline $\mathrm{H}$ & 5.473392 & 1.721187 & -0.983311 \\
\hline $\mathrm{C}$ & 4.209347 & 2.204352 & 1.446637 \\
\hline $\mathrm{H}$ & 4.299995 & 1.201167 & 1.877438 \\
\hline $\mathrm{H}$ & 5.206225 & 2.658103 & 1.417592 \\
\hline $\mathrm{H}$ & 3.571203 & 2.810164 & 2.100068 \\
\hline $\mathrm{C}$ & 3.504910 & 3.545956 & -0.537771 \\
\hline $\mathrm{H}$ & 3.053616 & 3.511579 & -1.535533 \\
\hline $\mathrm{H}$ & 2.877853 & 4.176077 & 0.102452 \\
\hline
\end{tabular}

$\begin{array}{lrrr}\mathrm{H} & 4.495504 & 4.007000 & -0.620127 \\ \mathrm{C} & -0.319631 & 2.635502 & -0.021705 \\ \mathrm{C} & -0.033274 & 3.282872 & 1.188669 \\ \mathrm{C} & -0.615433 & 3.414217 & -1.149787 \\ \mathrm{C} & -0.077380 & 4.666802 & 1.271696 \\ \mathrm{H} & 0.218183 & 2.683609 & 2.059838 \\ \mathrm{C} & -0.653446 & 4.796693 & -1.058310 \\ \mathrm{H} & -0.812702 & 2.904848 & -2.089972 \\ \mathrm{C} & -0.387923 & 5.429291 & 0.151656 \\ \mathrm{H} & 0.137040 & 5.155137 & 2.218461 \\ \mathrm{H} & -0.889661 & 5.386942 & -1.939447 \\ \mathrm{H} & -0.420256 & 6.512583 & 0.220261\end{array}$

IM3-CM M06/6-311g(d,p)/superfine in PhCF3 Solvent IM3-CM same as IM0-CM Pathway 4 


\section{Isodesmic Reactions (Table S8)}

\section{Reaction 1:}

$\mathrm{Br}_{2} \operatorname{Ti}\left(\mathrm{N}^{t} \mathrm{Bu}\right) \mathrm{py}_{3}$

M06/6-311g(d,p)/superfine in PhCF3 Solvent

Electronic energy -6954.716968 a.u.

Gibbs free energy -6954.414458 (-6954.412159) a.u. 50

$\begin{array}{lrrr}\mathrm{Ti} & -0.042482 & -0.339038 & 0.051465 \\ \mathrm{~N} & 0.501309 & 2.069457 & -0.075009 \\ \mathrm{~N} & 2.194481 & -0.584577 & 0.151263 \\ \mathrm{~N} & -0.479303 & -1.949565 & 0.089990 \\ \mathrm{C} & 2.772146 & -1.542402 & -0.587765 \\ \mathrm{C} & 2.981382 & 0.167982 & 0.932064 \\ \mathrm{C} & 4.134102 & -1.779254 & -0.574704 \\ \mathrm{C} & 4.352735 & 0.000023 & 0.998257 \\ \mathrm{C} & 4.941971 & -0.992898 & 0.232122 \\ \mathrm{H} & 2.107724 & -2.128557 & -1.213873 \\ \mathrm{H} & 4.546973 & -2.569891 & -1.190855 \\ \mathrm{H} & 6.014996 & -1.153614 & 0.264485 \\ \mathrm{H} & 4.940797 & 0.639866 & 1.646338 \\ \mathrm{H} & 2.482213 & 0.922801 & 1.531866 \\ \mathrm{C} & -0.098365 & 2.957823 & 0.726612 \\ \mathrm{C} & 0.178838 & 4.314130 & 0.699211 \\ \mathrm{C} & 1.136308 & 4.780696 & -0.187725 \\ \mathrm{C} & 1.770253 & 3.869982 & -1.018204 \\ \mathrm{C} & 1.416683 & 2.533756 & -0.934006 \\ \mathrm{H} & -0.824499 & 2.556672 & 1.428561 \\ \mathrm{H} & -0.347040 & 4.985352 & 1.369288 \\ \mathrm{H} & 1.383912 & 5.836897 & -0.231375 \\ \mathrm{H} & 1.873539 & 1.797624 & -1.590427 \\ \mathrm{H} & 2.526430 & 4.183552 & -1.729463 \\ \mathrm{Br} & -0.060517 & 0.089509 & 2.601488 \\ \mathrm{Br} & 0.145945 & -0.202589 & -2.533098 \\ \mathrm{~N} & -2.154385 & 0.444931 & -0.081384 \\ \mathrm{C} & -3.072023 & -0.045479 & 0.764582 \\ \mathrm{C} & -2.553885 & 1.346204 & -0.988145 \\ \mathrm{C} & -4.399101 & 0.340600 & 0.736736 \\ \mathrm{H} & -2.586775 & -4.339568 & -1.012732 \\ \mathrm{H} & -2.713913 & -0.769132 & 1.490001 \\ \mathrm{C} & -3.862033 & 1.787251 & -1.081319 \\ \mathrm{H} & -1.791294 & 1.713444 & -1.668082 \\ \mathrm{C} & -4.804133 & 1.275301 & -0.204146 \\ \mathrm{H} & -5.098143 & -0.090251 & 1.444516 \\ \mathrm{H} & -2.010439 & -2.706997 & -0.454314 \\ \mathrm{H} & -4.128528 & 2.518798 & -1.835672 \\ \mathrm{H} & -5.839265 & 1.598288 & -0.253158 \\ \mathrm{C} & -0.969591 & -3.298323 & 0.008439 \\ \mathrm{C} & -1.323422 & -3.791808 & 1.410051 \\ \mathrm{H} & -2.100971 & -3.161901 & 1.857867 \\ \mathrm{H} & -1.690443 & -4.826018 & 1.380068 \\ \mathrm{H} & -0.443327 & -3.751881 & 2.062378 \\ \mathrm{H} & 0.110437 & -4.194908 & -0.594967 \\ -0.242258 & -5.231489 & -0.671134 \\ \mathrm{H} & 0.378947 & -3.847958 & -1.599915 \\ \mathrm{H} & -2.208290 & -4.185309 & 0.028681 \\ \mathrm{H} & -3.316797 & -0.886907 \\ \mathrm{H} & & & \\ \mathrm{H} & -965137 & -2.907077 & -1.874044 \\ \mathrm{H} & -12345 & & \end{array}$

p-methylphenyl isocyanide

M06/6-311g(d,p)/superfine in PhCF3 Solvent

Electronic energy -363.597260 a.u.

Gibbs free energy $-363.519280(-363.519127)$ a.u. 16

$\begin{array}{lccc}\mathrm{C} & -3.684072 & -0.002149 & 0.008468 \\ \mathrm{~N} & -2.514772 & -0.000728 & 0.004566 \\ \mathrm{C} & -1.128442 & 0.000406 & 0.001114 \\ \mathrm{C} & -0.440511 & -1.209322 & -0.002957 \\ \mathrm{C} & -0.442218 & 1.210208 & -0.002897 \\ \mathrm{C} & 0.942829 & -1.197290 & -0.009478 \\ \mathrm{H} & -0.996684 & -2.141088 & -0.004370 \\ \mathrm{C} & 0.942020 & 1.199873 & -0.009421 \\ \mathrm{H} & -0.999186 & 2.141489 & -0.004346 \\ \mathrm{C} & 1.656465 & 0.002041 & -0.010237 \\ \mathrm{H} & 1.485210 & -2.139290 & -0.016150 \\ \mathrm{H} & 1.482844 & 2.142603 & -0.016244 \\ \mathrm{C} & 3.151836 & -0.001291 & 0.012757 \\ \mathrm{H} & 3.524403 & -0.093594 & 1.040751 \\ \mathrm{H} & 3.557940 & -0.844663 & -0.554465 \\ \mathrm{H} & 3.561442 & 0.924777 & -0.401229\end{array}$

$\mathrm{Br}_{2} \mathrm{Ti}(\mathrm{p}$-methylphenyl imido)py

M06/6-311g(d,p)/superfine in PhCF3 Solvent

Electronic energy -7067.777940 a.u.

Gibbs free energy -7067.485199 (-7067.480665) a.u. 51

$\begin{array}{llll}\mathrm{Ti} & -0.204907 & -0.027508 & -0.057384\end{array}$

$\mathrm{N} \quad-2.640976 \quad 0.116815 \quad 0.096550$

$\begin{array}{llll}\mathrm{N} & -0.300771 & 2.212631 & -0.040035\end{array}$

$\mathrm{N} \quad 1.483700 \quad-0.096894 \quad-0.122870$

$\begin{array}{llll}\text { C } & 2.845262 & -0.102947 & -0.072775\end{array}$

$\begin{array}{llll}\mathrm{C} & 3.600445 & -1.033182 & -0.804922\end{array}$

$\begin{array}{llll}\mathrm{C} & 4.985340 & -1.026385 & -0.740501\end{array}$

$\begin{array}{llll}\mathrm{C} & 3.538685 & 0.828902 & 0.723088\end{array}$

$\begin{array}{llll}\mathrm{C} & 4.920079 & 0.822532 & 0.773473\end{array}$

$\begin{array}{llll}\text { C } & 5.673301 & -0.102452 & 0.044593\end{array}$

$\begin{array}{llll}\mathrm{H} & 3.074728 & -1.755378 & -1.425807\end{array}$

$\begin{array}{llll}\mathrm{H} & 5.550765 & -1.756600 & -1.316976\end{array}$

$\begin{array}{llll}\mathrm{H} & 5.437255 & 1.551311 & 1.396189\end{array}$

$\begin{array}{llll}\mathrm{H} & 2.958721 & 1.546616 & 1.299358\end{array}$

$\begin{array}{llll}\text { C } & 0.550960 & 2.885399 & -0.827971\end{array}$

$\begin{array}{llll}\mathrm{C} & -1.121476 & 2.918639 & 0.749278\end{array}$

$\begin{array}{llll}\mathrm{C} & 0.606623 & 4.266144 & -0.860886\end{array}$

$\begin{array}{llll}\text { C } & -1.130698 & 4.301347 & 0.773326\end{array}$

$\begin{array}{llll}\mathrm{C} & -0.251154 & 4.989798 & -0.046908\end{array}$

$\begin{array}{llll}\mathrm{H} & 1.205823 & 2.284034 & -1.450534\end{array}$

$\begin{array}{llll}\mathrm{H} & 1.316664 & 4.758030 & -1.515785\end{array}$

$\begin{array}{llll}\mathrm{H} & -0.231190 & 6.075088 & -0.048890\end{array}$

$\begin{array}{llll}\mathrm{H} & -1.817557 & 4.821327 & 1.431308\end{array}$

$\begin{array}{llll}\mathrm{H} & -1.784728 & 2.346793 & 1.390865\end{array}$

$\begin{array}{llll}\text { C } & -3.323723 & -0.552688 & 1.034525\end{array}$

$\begin{array}{llll}\text { C } & -4.702344 & -0.505097 & 1.148753\end{array}$

$\begin{array}{llll}\mathrm{C} & -5.418021 & 0.286056 & 0.264096\end{array}$

$\begin{array}{llll}\text { C } & -4.723240 & 0.990876 & -0.705815\end{array}$

$\begin{array}{llll}\text { C } & -3.345264 & 0.870547 & -0.757925\end{array}$

$\begin{array}{llll}\mathrm{H} & -2.730759 & -1.141081 & 1.729178\end{array}$

$\mathrm{H} \quad \begin{array}{llll}-5.197610 & -1.076936 & 1.925555\end{array}$

$\begin{array}{llll}\mathrm{H} & -6.499608 & 0.352378 & 0.329706\end{array}$

$\begin{array}{llll}\mathrm{H} & -2.773777 & 1.389016 & -1.522622\end{array}$

$\begin{array}{llll}\mathrm{H} & -5.235047 & 1.624411 & -1.421724\end{array}$

$\begin{array}{llll}\mathrm{Br} & -0.314137 & -0.021299 & 2.509143\end{array}$

$\begin{array}{llll}\mathrm{Br} & -0.616905 & -0.018691 & -2.588458\end{array}$

$\begin{array}{llll}\mathrm{N} & -0.536448 & -2.241729 & -0.045885\end{array}$

$\begin{array}{llll}\text { C } & 0.345525 & -3.010696 & 0.609675\end{array}$

$\begin{array}{llll}\text { C } & -1.540322 & -2.845756 & -0.696081\end{array}$

$\begin{array}{llll}\mathrm{C} & 0.252296 & -4.389340 & 0.645437\end{array}$

$\begin{array}{llll}\mathrm{H} & 1.148777 & -2.490495 & 1.121910\end{array}$

$\begin{array}{llll}\mathrm{C} & -1.706605 & -4.218418 & -0.705617\end{array}$

$\mathrm{H} \quad-2.225266 \quad-2.198793 \quad-1.235480$ 


$\begin{array}{lrrr}\mathrm{C} & -0.794307 & -5.006552 & -0.022195 \\ \mathrm{H} & 0.994843 & -4.962580 & 1.188871 \\ \mathrm{H} & -2.538404 & -4.654388 & -1.247069 \\ \mathrm{H} & -0.895018 & -6.087224 & -0.013236 \\ \mathrm{C} & 7.169774 & -0.087036 & 0.111100 \\ \mathrm{H} & 7.578022 & 0.859796 & -0.264334 \\ \mathrm{H} & 7.527134 & -0.198163 & 1.142384 \\ \mathrm{H} & 7.605300 & -0.896273 & -0.483205 \\ & & & \\ \mathrm{CN}^{t} \mathrm{Bu} & & & \end{array}$

M06/6-311g(d,p)/superfine in PhCF3 Solvent

Electronic energy -250.549697 a.u.

Gibbs free energy -250.463767 (-250.463767) a.u.

15

$\begin{array}{llll}\mathrm{C} & 2.350482 & 0.000089 & -0.000086\end{array}$

$\begin{array}{llll}\mathrm{N} & 1.184393 & 0.000197 & -0.000043\end{array}$

$\begin{array}{llll}\text { C } & -0.265633 & -0.000006 & 0.000092\end{array}$

$\begin{array}{llll}\mathrm{C} & -0.729443 & 1.184183 & 0.835226\end{array}$

$\begin{array}{llll}\mathrm{H} & -1.823932 & 1.208058 & 0.851040\end{array}$

$\begin{array}{llll}\mathrm{H} & -0.367552 & 1.099780 & 1.864731\end{array}$

$\begin{array}{llll}\mathrm{H} & -0.366194 & 2.125341 & 0.410617\end{array}$

$\begin{array}{llll}\text { C } & -0.729110 & -1.315596 & 0.607873\end{array}$

$\mathrm{H} \quad-1.823602 \quad-1.341788 \quad 0.620241$

$\mathrm{H} \quad-0.366586 \quad-2.164610 \quad 0.019830$

$\begin{array}{llll}\mathrm{H} & -0.366208 & -1.418661 & 1.635331\end{array}$

$\begin{array}{llll}\mathrm{C} & -0.729473 & 0.131218 & -1.443013\end{array}$

$\begin{array}{llll}\mathrm{H} & -1.823968 & 0.135070 & -1.471407\end{array}$

$\mathrm{H} \quad-0.365758 \quad 1.064097 \quad-1.885096$

$\begin{array}{llll}\mathrm{H} & -0.367887 & -0.707992 & -2.045538\end{array}$ 
Reaction 2:

$\mathrm{Br}_{2} \mathrm{Ti}\left(\mathrm{N}^{t} \mathrm{Bu}\right) \mathrm{py}_{3}$

M06/6-311 $\mathrm{g}(\mathrm{d}, \mathrm{p}) /$ superfine in PhCF3 Solvent

Same as Reaction 1

$\mathrm{CNPh}$

M06/6-311g(d,p)/superfine in PhCF3 Solvent

Electronic energy -324.300946 a.u.

Gibbs free energy -324.245274 (-324.245274) a.u.

13

C

C $\quad 3.181701$

$\mathrm{N} \quad 2.012372$

C $\quad 0.625815$

C $\quad-0.055624$

C $\quad-0.055632$

C $\quad-1.441036$

$\mathrm{H} \quad 0.506807$

C $\quad-1.441046$

$\mathrm{H} \quad 0.506801$

C $\quad-2.133500$

$\mathrm{H} \quad-1.982647$

$\mathrm{H} \quad-1.982673$

$\mathrm{H} \quad-3.218970$

0.000007

$-0.000011$

$-0.000005$

1.213354

$-1.213357$

1.204725

2.141206

$-1.204718$

$-2.141209$

0.000005

2.145211

$-2.145196$

0.000002

0.000018

$-0.000009$

$-0.000005$

0.000014

$-0.000025$

$-0.000013$

0.000027

0.000023

$-0.000085$

0.000008

$-0.000059$

0.000065

$-0.000007$

$\mathrm{Br}_{2} \mathrm{Ti}(\mathrm{NPh}) \mathrm{py}_{3}$

M06/6-311g(d,p)/superfine in PhCF3 Solvent

Electronic energy -7028.483069 a.u.

Gibbs free energy -7028.212057 (-7028.208528) a.u. 48

$$
0.016217
$$

$-2.406103$

0.001983

1.703279

3.061820

3.806223

5.188410

3.756506

5.138590

5.864131

3.272435

5.746940

5.657759

3.178992

0.864302

$-0.776650$

0.973270

$-0.731349$

0.159857

1.483855

1.689796

0.222632

$-1.385143$

$-1.449797$

$-3.102911$

$-4.478204$

$-5.174344$

$-4.464348$

$-3.091717$

$-2.524416$

$-4.985674$

$-6.252486$

$-2.509992$

$-4.960568$

$\mathrm{Br} \quad-0.066072$

$\begin{array}{lrrc}\mathrm{Br} & -0.424972 & -0.013744 & -2.594493 \\ \mathrm{~N} & -0.397307 & -2.237230 & -0.054960 \\ \mathrm{C} & 0.458803 & -3.038796 & 0.595855 \\ \mathrm{C} & -1.428641 & -2.803321 & -0.696532 \\ \mathrm{C} & 0.312664 & -4.412712 & 0.634989 \\ \mathrm{H} & 1.285180 & -2.549396 & 1.101603 \\ \mathrm{C} & -1.647892 & -4.168508 & -0.702147 \\ \mathrm{H} & -2.092599 & -2.131619 & -1.231937 \\ \mathrm{C} & -0.761741 & -4.990289 & -0.023813 \\ \mathrm{H} & 1.036103 & -5.013175 & 1.174492 \\ \mathrm{H} & -2.500237 & -4.572611 & -1.236393 \\ \mathrm{H} & -0.904424 & -6.066178 & -0.011879 \\ \mathrm{H} & 6.947772 & -0.287006 & 0.178071\end{array}$

$\mathrm{CN}^{t} \mathrm{Bu}$

M06/6-311g(d,p)/superfine in PhCF3 Solvent Same as Reaction 1 


\section{Reaction 3:}

$\mathrm{PhNNPh}$

M06/6-311g(d,p)/superfine in PhCF3 Solvent

Electronic energy -572.454319 a.u.

Gibbs free energy $-572.319306(-572.319239)$ a.u.

24

$\mathrm{N}$

-0.619436
-1.406429
-1.221260
-2.100635
-2.483239
-3.334243
-3.145895
-0.405679
-1.966304
-4.158821
-3.824481
-2.630628
0.619438
1.406394
2.483403
1.221083
3.145914
3.334406
2.100486
2.630950
3.824525
4.159130
1.966043
0.405343

1.967041

$-0.001678$

$0.776359 \quad 0.087398$

$-0.165305 \quad 1.097520$

$-1.231730 \quad 1.201281$

$0.669769-0.787582$

$-0.420637 \quad-0.699467$

$\begin{array}{ll}-1.372410 & 0.295722\end{array}$

$-0.051064 \quad 1.805365$

$-1.961035 \quad 1.994473$

$-0.518787 \quad-1.398954$

$\begin{array}{ll}-2.215976 & 0.376742\end{array}$

$1.443000 \quad-1.536402$

$1.967019 \quad 0.001454$

$0.776280 \quad-0.087432$

$0.669931 \quad 0.787346$

$-0.165635$

$-1.372486$

$-0.420485$

$-1.232037$

1.443360

$-2.216036$

$-0.518431$

$-1.961506$

$-0.051628$
$\mathrm{H}$

C

C

C

$\mathrm{H}$

$\mathrm{H}$

$\mathrm{H}$

$-1.097306$

$-0.295601$

0.699339

$-1.200999$

1.535931

$-0.376571$

1.398684

$-1.994022$

$-1.805001$

Xylyl isocyanide

M06/6-311g(d,p)/superfine in PhCF3 Solvent

Electronic energy -402.896870 a.u.

Gibbs free energy -402.792929 (-402.792929) a.u.

19

$\begin{array}{lrrr}\mathrm{C} & 0.429554 & 0.000984 & -0.000010 \\ \mathrm{C} & -0.238887 & 1.231063 & 0.000027 \\ \mathrm{C} & -1.628752 & 1.200863 & 0.000005 \\ \mathrm{C} & -2.314659 & -0.005172 & -0.000049 \\ \mathrm{C} & -1.623350 & -1.208126 & -0.000038 \\ \mathrm{C} & -0.233377 & -1.232084 & -0.000000 \\ \mathrm{H} & -2.173823 & 2.140789 & 0.000034 \\ \mathrm{H} & -3.400591 & -0.007606 & -0.000075 \\ \mathrm{H} & -2.164217 & -2.150473 & -0.000046 \\ \mathrm{C} & 0.523065 & 2.514901 & 0.000057 \\ \mathrm{H} & 1.173326 & 2.591733 & 0.879239 \\ \mathrm{H} & 1.172316 & 2.592340 & -0.879827 \\ \mathrm{H} & -0.156532 & 3.370096 & 0.000725 \\ \mathrm{C} & 0.534361 & -2.512468 & 0.000076 \\ \mathrm{H} & 1.184390 & -2.586750 & -0.879474 \\ \mathrm{H} & 1.184520 & -2.586573 & 0.879562 \\ \mathrm{H} & -0.141341 & -3.370739 & 0.000210 \\ \mathrm{~N} & 1.816495 & 0.004052 & -0.000044 \\ \mathrm{C} & 2.986459 & 0.006509 & -0.000076\end{array}$

Phenyl xylyl carbodiimide

M06/6-311g(d,p)/superfine in PhCF3 Solvent

lectronic energy -689.189180 a.u.

Gibbs free energy -689.004457 (-689.002743) a.u.

31

$\begin{array}{llll}\mathrm{C} & 0.283304 & 0.832614 & 0.383917 \\ \mathrm{~N} & -0.864636 & 0.942091 & 0.031600 \\ \mathrm{~N} & 1.426443 & 0.893915 & 0.798703 \\ \mathrm{C} & 2.636843 & 0.417046 & 0.286404\end{array}$


$\mathrm{PhNNPh}$

M06/6-311 $\mathrm{g}(\mathrm{d}, \mathrm{p}) /$ superfine in PhCF3 Solvent

Same as Reaction 3

Cyclohexyl isocyanide

M06/6-311g(d,p)/superfine in PhCF3 Solvent

Electronic energy -327.931984 a.u.

Gibbs free energy $-327.809480(-327.809480)$ a.u.

19

$\begin{array}{lrrr}\mathrm{C} & -0.065058 & 1.260421 & -0.144159 \\ \mathrm{C} & -0.730467 & -0.000004 & 0.398331 \\ \mathrm{C} & -0.065049 & -1.260431 & -0.144146 \\ \mathrm{C} & 1.420527 & -1.254874 & 0.186310 \\ \mathrm{C} & 2.100130 & 0.000011 & -0.344919 \\ \mathrm{C} & 1.420510 & 1.254880 & 0.186326 \\ \mathrm{H} & -0.561800 & -2.145421 & 0.268402 \\ \mathrm{H} & -0.667078 & 0.000003 & 1.495948 \\ \mathrm{H} & -0.209607 & 1.281666 & -1.234166 \\ \mathrm{H} & -0.561828 & 2.145414 & 0.268363 \\ \mathrm{H} & 1.547937 & -1.302202 & 1.278369 \\ \mathrm{H} & 1.892522 & -2.154716 & -0.223231 \\ \mathrm{H} & 3.163104 & 0.000015 & -0.077968 \\ \mathrm{H} & 2.049532 & 0.000020 & -1.444311 \\ \mathrm{H} & 1.547898 & 1.302185 & 1.278390 \\ \mathrm{H} & 1.892505 & 2.154737 & -0.223185 \\ \mathrm{H} & -0.209619 & -1.281697 & -1.234150 \\ \mathrm{C} & -3.250372 & 0.000008 & -0.236771 \\ \mathrm{~N} & -2.123556 & -0.000010 & 0.063101\end{array}$

Phenyl cyclohexyl carbodiimide

M06/6-311g(d,p)/superfine in PhCF3 Solvent

Electronic energy -614.222071 a.u.

Gibbs free energy -614.019587 (-614.017696) a.u.

$\begin{array}{lrrr}31 & & & \\ \mathrm{C} & -0.226316 & -1.296652 & -0.131383 \\ \mathrm{~N} & 0.900387 & -1.339971 & -0.550809 \\ \mathrm{~N} & -1.386666 & -1.403350 & 0.245704 \\ \mathrm{C} & -2.448449 & -0.505754 & 0.075564 \\ \mathrm{C} & -2.298749 & 0.734094 & -0.549698 \\ \mathrm{C} & -3.698987 & -0.880680 & 0.563805 \\ \mathrm{C} & -3.388575 & 1.580265 & -0.679871 \\ \mathrm{H} & -1.324767 & 1.030480 & -0.931775 \\ \mathrm{C} & -4.784313 & -0.028336 & 0.428843 \\ \mathrm{H} & -3.799508 & -1.847425 & 1.048319 \\ \mathrm{C} & -4.635320 & 1.204890 & -0.192886 \\ \mathrm{H} & -3.262075 & 2.542932 & -1.166849 \\ \mathrm{H} & -5.754031 & -0.331279 & 0.812809 \\ \mathrm{H} & -5.485477 & 1.872068 & -0.296313 \\ \mathrm{C} & 2.182054 & -0.843589 & -0.063987 \\ \mathrm{C} & 3.000259 & -0.336802 & -1.242277 \\ \mathrm{C} & 2.021811 & 0.235938 & 0.997082 \\ \mathrm{H} & 2.707940 & -1.704312 & 0.379009 \\ \mathrm{C} & 4.356675 & 0.177027 & -0.780942 \\ \mathrm{H} & 2.436450 & 0.475851 & -1.725796 \\ \mathrm{H} & 3.108599 & -1.137479 & -1.983088 \\ \mathrm{C} & 3.378875 & 0.751295 & 1.456809 \\ \mathrm{H} & 1.437785 & 1.061912 & 0.560665 \\ \mathrm{H} & 1.445858 & -0.156568 & 1.844066 \\ \mathrm{C} & 4.203616 & 1.257457 & 0.281241 \\ \mathrm{H} & 4.925131 & 0.554508 & -1.638446 \\ \mathrm{H} & 4.937085 & -0.660156 & -0.363783 \\ \mathrm{H} & 3.243577 & 1.540932 & 2.204724 \\ \mathrm{H} & 3.923510 & -0.063994 & 1.956823 \\ \mathrm{H} & 5.187021 & 1.600007 & 0.623933 \\ & & & \\ & & & \\ & & \end{array}$


Reaction 5:

$\mathrm{PhNNPh}$

M06/6-311g(d,p)/superfine in PhCF3 Solvent

Same as Reaction 3

$\mathrm{CN}^{t} \mathrm{Bu}$

M06/6-311 $\mathrm{g}(\mathrm{d}, \mathrm{p}) /$ superfine in PhCF3 Solvent

Same as Reaction 1

Phenyl ${ }^{t}$ Butyl carbodiimide

M06/6-311g(d,p)/superfine in PhCF3 Solvent

Electronic energy -536.840390 a.u.

Gibbs free energy -536.673604 (-536.672739) a.u.

27

C

1.784663

$-0.769186 \quad-0.404680$

$\begin{array}{lll}1.784663 & -0.437719 & -0.721373\end{array}$

$\mathrm{N} \quad-0.443425 \quad-1.220461 \quad-0.171813$

$\begin{array}{llll}\text { C } & -1.652941 & -0.515651 & -0.092424\end{array}$

$\begin{array}{llll}\text { C } & -1.719460 & 0.878542 & -0.141933\end{array}$

$\begin{array}{llll}\text { C } & -2.825831 & -1.253510 & 0.055376\end{array}$

$\begin{array}{llll}\mathrm{C} & -2.945787 & 1.517191 & -0.048539\end{array}$

$\mathrm{H} \quad-0.805110 \quad 1.457650 \quad-0.251930$

$\begin{array}{llll}\mathrm{C} & -4.048986 & -0.606719 & 0.146821\end{array}$

$\begin{array}{llll}\mathrm{H} & -2.757308 & -2.336618 & 0.095775\end{array}$

$\begin{array}{llll}\mathrm{C} & -4.115468 & 0.779785 & 0.095022\end{array}$

$\begin{array}{llll}\mathrm{H} & -2.987880 & 2.601893 & -0.087405\end{array}$

$\begin{array}{llll}\mathrm{H} & -4.957083 & -1.191586 & 0.259994\end{array}$

$\begin{array}{llll}\mathrm{H} & -5.073539 & 1.284927 & 0.169097\end{array}$

$\begin{array}{llll}\mathrm{C} & 2.910799 & 0.126401 & 0.050694\end{array}$

$\begin{array}{llll}\mathrm{C} & 3.202413 & 1.498929 & -0.534903\end{array}$

$\mathrm{H} \quad 4.061794 \quad 1.949056 \quad-0.025721$

$\mathrm{H} \quad 3.431271 \quad 1.423205 \quad-1.603018$

$\begin{array}{llll}\mathrm{H} & 2.340384 & 2.164432 & -0.411613\end{array}$

$\begin{array}{llll}\mathrm{C} & 2.552030 & 0.236678 & 1.523059\end{array}$

$\begin{array}{llll}\mathrm{H} & 2.320714 & -0.746850 & 1.947104\end{array}$

$\begin{array}{llll}\mathrm{H} & 3.394022 & 0.658871 & 2.082431\end{array}$

$\begin{array}{llll}\mathrm{H} & 1.684814 & 0.892532 & 1.667186\end{array}$

$\begin{array}{llll}\mathrm{C} & 4.098379 & -0.801118 & -0.148383\end{array}$

$\mathrm{H} \quad 4.336707 \quad-0.900054 \quad-1.212555$

$\begin{array}{llll}\mathrm{H} & 4.977077 & -0.400689 & 0.369128\end{array}$

$\begin{array}{llll}\mathrm{H} & 3.884767 & -1.797574 & 0.253170\end{array}$ 


\section{Reaction 6:}

Adamantyl Azide

M06/6-311 $\mathrm{g}(\mathrm{d}, \mathrm{p}) /$ superfine in PhCF3 Solvent

Electronic energy -554.062710 a.u.

Gibbs free energy $-553.868636(-553.868210)$ a.u.

28

$\begin{array}{lrrr}\mathrm{N} & -2.000753 & 0.824674 & -0.002703 \\ \mathrm{~N} & -2.974873 & 0.095508 & 0.021433 \\ \mathrm{~N} & -3.932447 & -0.511907 & -0.011214 \\ \mathrm{C} & -0.784355 & 0.310629 & 0.688267 \\ \mathrm{C} & 0.327490 & 1.338906 & 0.508529 \\ \mathrm{H} & -1.026911 & 0.215424 & 1.758492 \\ \mathrm{C} & -0.334729 & -1.049697 & 0.148480 \\ \mathrm{C} & 0.711785 & 1.447373 & -0.968182 \\ \mathrm{H} & -0.028587 & 2.309285 & 0.878467 \\ \mathrm{C} & 1.538979 & 0.875548 & 1.320914 \\ \mathrm{C} & 0.877838 & -1.502542 & 0.965785 \\ \mathrm{C} & 0.052974 & -0.932938 & -1.326599 \\ \mathrm{H} & -1.152806 & -1.774099 & 0.269056 \\ \mathrm{H} & 1.510890 & 2.192634 & -1.081051 \\ \mathrm{H} & -0.144241 & 1.799726 & -1.557562 \\ \mathrm{C} & 1.184563 & 0.085415 & -1.480708 \\ \mathrm{H} & 1.278934 & 0.811343 & 2.386647 \\ \mathrm{H} & 2.345050 & 1.615643 & 1.228332 \\ \mathrm{C} & 2.011763 & -0.487313 & 0.811189 \\ \mathrm{H} & 1.203067 & -2.492215 & 0.617817 \\ \mathrm{H} & 0.603318 & -1.605251 & 2.024805 \\ \mathrm{H} & -0.814022 & -0.632683 & -1.929721 \\ \mathrm{H} & 0.375241 & -1.916363 & -1.694931 \\ \mathrm{H} & 1.461948 & 0.167709 & -2.539567 \\ \mathrm{C} & 2.395473 & -0.373587 & -0.665655 \\ \mathrm{H} & 2.880528 & -0.816738 & 1.395589 \\ \mathrm{H} & 3.221356 & 0.341840 & -0.784589 \\ \mathrm{H} & 2.752054 & -1.344934 & -1.036519\end{array}$

Xylyl isocyanide

M06/6-311g(d,p)/superfine in PhCF3 Solvent

Same as Reaction 3

Adamantyl xylyl carbodiimide

M06/6-311g(d,p)/superfine in PhCF3 Solvent

Electronic energy -847.588312 a.u.

Gibbs free energy $-847.267982(-847.264969)$ a.u.

$\begin{array}{lccc}45 & & & \\ \mathrm{C} & 0.743593 & 0.833650 & -0.320049 \\ \mathrm{~N} & 1.944271 & 1.010374 & -0.229873 \\ \mathrm{C} & 3.095440 & 0.239024 & -0.079072 \\ \mathrm{C} & 4.299835 & 0.943424 & 0.083079 \\ \mathrm{C} & 3.074264 & -1.165987 & -0.093197 \\ \mathrm{C} & 5.478701 & 0.223557 & 0.238503 \\ \mathrm{C} & 4.278802 & -1.845291 & 0.066184 \\ \mathrm{C} & 5.474532 & -1.163553 & 0.231589 \\ \mathrm{H} & 6.412030 & 0.766659 & 0.365815 \\ \mathrm{H} & 4.268369 & -2.932694 & 0.056519 \\ \mathrm{H} & 6.403110 & -1.713341 & 0.353716 \\ \mathrm{C} & 1.798426 & -1.922066 & -0.278122 \\ \mathrm{H} & 1.070019 & -1.695437 & 0.511101 \\ \mathrm{H} & 1.318468 & -1.681765 & -1.234378 \\ \mathrm{H} & 1.982526 & -2.999359 & -0.259666 \\ \mathrm{C} & 4.303561 & 2.438539 & 0.088710 \\ \mathrm{H} & 3.900616 & 2.843152 & -0.846821 \\ \mathrm{H} & 3.677567 & 2.838200 & 0.894810 \\ \mathrm{H} & 5.318090 & 2.824584 & 0.219760 \\ \mathrm{~N} & -0.443691 & 0.794305 & -0.535440 \\ \mathrm{C} & -1.614874 & 0.778077 & 0.333815\end{array}$

$\begin{array}{lrrr}\mathrm{C} & -1.961004 & -0.652120 & 0.767550 \\ \mathrm{H} & -1.395822 & 1.376089 & 1.231529 \\ \mathrm{C} & -2.813416 & 1.394986 & -0.391750 \\ \mathrm{C} & -2.343674 & -1.497660 & -0.447645 \\ \mathrm{H} & -1.085961 & -1.087020 & 1.270570 \\ \mathrm{C} & -3.142395 & -0.587222 & 1.738308 \\ \mathrm{C} & -3.991652 & 1.451453 & 0.582462 \\ \mathrm{C} & -3.190828 & 0.543464 & -1.604510 \\ \mathrm{H} & -2.541641 & 2.408830 & -0.714244 \\ \mathrm{H} & -2.583255 & -2.518690 & -0.119637 \\ \mathrm{H} & -1.497824 & -1.571696 & -1.143378 \\ \mathrm{C} & -3.551158 & -0.872357 & -1.149712 \\ \mathrm{H} & -2.872058 & 0.002476 & 2.625382 \\ \mathrm{H} & -3.386082 & -1.600644 & 2.085472 \\ \mathrm{C} & -4.351969 & 0.036878 & 1.039868 \\ \mathrm{H} & -4.853304 & 1.921474 & 0.089272 \\ \mathrm{H} & -3.736252 & 2.075419 & 1.450488 \\ \mathrm{H} & -2.357560 & 0.513297 & -2.318071 \\ \mathrm{H} & -4.043968 & 1.003652 & -2.121801 \\ \mathrm{H} & -3.823948 & -1.480621 & -2.022016 \\ \mathrm{C} & -4.730231 & -0.810570 & -0.176551 \\ \mathrm{H} & -5.197456 & 0.080114 & 1.738779 \\ \mathrm{H} & -5.007228 & -1.824951 & 0.144013 \\ \mathrm{H} & -5.608223 & -0.377833 & -0.676788\end{array}$


Reaction 7:

p-methylphenyl azide

M06/6-311 g(d,p)/superfine in PhCF3 Solvent

Electronic energy -434.957446 a.u.

Gibbs free energy -434.877861 (-434.876717) a.u. 17

$\begin{array}{lrrr}\mathrm{C} & -1.619858 & 1.145273 & 0.000615 \\ \mathrm{C} & -0.270305 & 1.446951 & 0.000192 \\ \mathrm{C} & 0.666701 & 0.417363 & -0.000082 \\ \mathrm{C} & 0.244134 & -0.906957 & 0.000376 \\ \mathrm{C} & -1.114202 & -1.190676 & 0.000752 \\ \mathrm{C} & -2.068571 & -0.177088 & 0.000624 \\ \mathrm{H} & -2.347917 & 1.953545 & 0.001068 \\ \mathrm{H} & 0.078122 & 2.475443 & 0.000299 \\ \mathrm{H} & 0.968970 & -1.717163 & 0.000691 \\ \mathrm{H} & -1.438819 & -2.228401 & 0.001349 \\ \mathrm{C} & -3.534347 & -0.481265 & -0.000977 \\ \mathrm{H} & -4.023815 & -0.071017 & -0.891882 \\ \mathrm{H} & -3.720436 & -1.558713 & 0.018149 \\ \mathrm{H} & -4.032815 & -0.037037 & 0.868257 \\ \mathrm{~N} & 2.031090 & 0.807990 & -0.000525 \\ \mathrm{~N} & 2.884402 & -0.067607 & -0.000310 \\ \mathrm{~N} & 3.755279 & -0.788707 & -0.000157\end{array}$

Xylyl isocyanide

M06/6-311g(d,p)/superfine in PhCF3 Solvent

Same as Reaction 3

p-methylphenyl xylyl carbodiimide

M06/6-311g(d,p)/superfine in PhCF3 Solvent

Electronic energy -728.484627 a.u.

Gibbs free energy $-728.276955(-728.275116)$ a.u.

34

$\begin{array}{llll}\mathrm{C} & 0.191699 & 0.919926 & -0.418334\end{array}$

$\begin{array}{llll}\mathrm{N} & 1.327552 & 0.973746 & -0.012469\end{array}$

$\begin{array}{lrrr}\mathrm{N} & -0.929778 & 1.038274 & -0.874819 \\ \mathrm{C} & -2.177243 & 0.587010 & -0.429550 \\ \mathrm{C} & -2.334090 & -0.143893 & 0.750422 \\ \mathrm{C} & -3.296703 & 0.879763 & -1.201636 \\ \mathrm{C} & -3.592706 & -0.567612 & 1.138333 \\ \mathrm{H} & -1.463755 & -0.374717 & 1.360107 \\ \mathrm{C} & -4.552388 & 0.448487 & -0.799868 \\ \mathrm{H} & -3.166274 & 1.446738 & -2.118703 \\ \mathrm{C} & -4.725458 & -0.280164 & 0.373869 \\ \mathrm{H} & -3.704286 & -1.136640 & 2.059095 \\ \mathrm{H} & -5.419127 & 0.683515 & -1.413181 \\ \mathrm{C} & 2.486717 & 0.195146 & -0.001294 \\ \mathrm{C} & 3.675607 & 0.838935 & 0.370834 \\ \mathrm{C} & 2.458856 & -1.171958 & -0.319796 \\ \mathrm{C} & 4.847884 & 0.092378 & 0.407285 \\ \mathrm{C} & 3.655781 & -1.879951 & -0.263735 \\ \mathrm{C} & 4.843047 & -1.258457 & 0.092503 \\ \mathrm{H} & 5.774864 & 0.584875 & 0.690235 \\ \mathrm{H} & 3.646592 & -2.939669 & -0.506695 \\ \mathrm{H} & 5.765996 & -1.829637 & 0.127955 \\ \mathrm{C} & 1.185946 & -1.855927 & -0.701087 \\ \mathrm{H} & 0.410266 & -1.728016 & 0.064667 \\ \mathrm{H} & 0.776559 & -1.466047 & -1.640778 \\ \mathrm{H} & 1.349173 & -2.928483 & -0.832384 \\ \mathrm{C} & 3.672213 & 2.294017 & 0.713144 \\ \mathrm{H} & 3.339133 & 2.904214 & -0.134293 \\ \mathrm{H} & 2.986003 & 2.507871 & 1.540523 \\ \mathrm{H} & 4.672312 & 2.628091 & 1.001705 \\ \mathrm{C} & -6.079149 & -0.739420 & 0.819119 \\ \mathrm{H} & -6.087303 & -1.815741 & 1.024529 \\ \mathrm{H} & -6.383603 & -0.236707 & 1.744911 \\ \mathrm{H} & -6.841040 & -0.533469 & 0.062073 \\ & & & \end{array}$

\section{References:}

1. Zhang, Z.; Li, Z.; Fu, Bin; Zhang, Z. Palladium-catalyzed cross-coupling reaction of azides with isocyanides. Chem. Commun. 2015, 51, 16312-16315.

2. Zhu, T.-H.; Wang, S.-Y.; Tao, T.-Q.; Ji, S.-J. Synthesis of carbodiimides by $\mathrm{I}_{2} / \mathrm{CHP}-$ mediated cross-coupling reaction of isocyanides with amines under metal-free conditions. Org. Lett. 2015, 17, 1974-1977.

3. Nguyen, A. I.; Zarkesh, R. A.; Lacy, D. C.; Thorson, M. K.; Heyduk, A. F. Catalytic nitrene transfer by a zirconium(IV) redox-active ligand complex. Chem. Sci. 2011, 2, 166169.

4. Royo, P.; Sánchez-Nieves, J. Oxo and imido/imido exchange and C-H activation reactions based on pentamethylcyclopentadienyl imido tantalum complexes. $J$. Organomet. Chem. 2000, 597, 61-68.

5. Davis-Gilbert, Z. W.; Wen, X.; Goodpaster, J. D.; Tonks, I. A. Mechanism of TiCatalyzed Oxidative Nitrene Transfer in [2+2+1] Pyrrole Synthesis from Alkynes and Azobenzene. J. Am. Chem. Soc. 2018, 140, 7267-7281. 